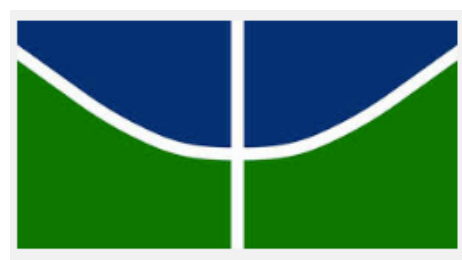

\author{
Universidade de Brasília \\ Instituto de Ciências Biológicas
}

Departamento de Botânica

Programa de Pós Graduação em Botânica

CARACTERIZAÇÃO MOLECULAR E ANATÔMICA DO COMPLEXO

BABAÇU (Attalea spp., Arecaceae)

Lorena Ramos da Mata

Brasília - DF

2016 
Lorena Ramos da Mata

\title{
CARACTERIZAÇÃO MOLECULAR E ANATÔMICA DO COMPLEXO BABAÇU (Attalea spp., Arecaceae)
}

\author{
Dissertação apresentada ao Programa de Pós-graduação \\ em Botânica do Instituto de Ciências Biológicas da \\ Universidade de Brasília como parte dos requisitos para \\ obtenção do título de Mestre em Botânica.
}

Orientadora: Dra. Vânia Cristina Rennó Azevedo

BRASÍLIA

DISTRITO FEDERAL - BRASIL 


\section{FICHA CATALOGRÁFICA}

DA MATA, Lorena Ramos.

Caracterização molecular e anatômica do complexo babaçu

(Attalea spp., Arecaceae)/ Lorena Ramos da Mata. - Brasília, DF [s.n.], 2016

Número de páginas p. 149: il.

Dissertação (Mestrado). Instituto de Ciências Biológicas da Universidade de Brasília/ Departamento de Botânica.

Orientadora: Vânia Cristina Rennó Azevedo.

Bibliografia.

1. Caracterização Molecular. 2. Caracterização anatômica. 3. Arecaceae

I. Título. II. Departamento de Botânica. 
Nome: DA MATA, Lorena Ramos.

Título: Caracterização molecular e anatômica do complexo babaçu (Attalea spp., Arecaceae)

Dissertação apresentada ao Programa de Pós-graduação em Botânica do Instituto de Ciências Biológicas da Universidade de Brasília como parte dos requisitos para obtenção do título de Mestre em Botânica.

Dissertação Aprovada em:

\section{Banca Examinadora}

$D^{\mathrm{a}}$. Conceição Eneida dos Santos - Examinadora

(UnB - Universidade de Brasilia)

Dr. Márcio de Carvalho Moretzsohn - Examinador

(Embrapa Cenargen)

Dra ${ }^{\mathrm{a}}$ Vânia Rennó Azevedo - Orientadora (Presidente)

(Embrapa Cenargen)

BRASÍLIA - DISTRITO FEDERAL

BRASIL - 2016 
"Porque Dele e por Ele, e para Ele, são todas as coisas; glória, pois a Ele eternamente. Amém." Romanos 11:36 


\section{AGRADECIMENTOS}

À Deus que sempre está no controle. Agradeço aos meus pais Samuel e Elenise, por tudo. Ao meu amado marido Henrique.

À minha orientadora Prof. Dra. Vânia Cristina Rennó Azevedo. Ao meu grande professor Dr. Peter Inglis.

Aos amigos do Laboratório de Genética Vegetal Da Embrapa Cenargen pela amizade e companheirismo, tais como: Natasha, Lucileide, Anádria, Tassiana, João, Flávio, Nayara, Bruna, Neide, Marília e Justino.

À Universidade de Brasília, Instituto de Ciências Biológicas, Departamento de Botânica, Programa de Pós Graduação em Botânica, especialmente à Dra. Conceição Eneida dos Santos, à Dra. Sueli Maria Gomes e à técnica Jéssica Vieira do Laboratório de Anatomia Vegetal.

À Embrapa Cenargen, especialmente aos pesquisadores Dr. Márcio de Carvalho Moretzsohn do Laboratório de Genética Vegetal, e ao pessoal do Laboratório de cultura de tecidos, Dr. Jonny Everson Scherwinski Pereira, e aos amigos André, Zan e Gabi, por todo apoio. À Embrapa Cocais, ao Dr. Marcelo Mattos Cavallari.

A todas as pessoas não mencionadas, porém não esquecidas. Sintam-se sinceramente agradecidos. 


\section{RESUMO GERAL}

DA MATA, Lorena Ramos. Caracterização molecular e anatômica do complexo babaçu (Attalea spp., Arecaceae) . 2016. 149p. Dissertação (Mestrado) - Departamento de Botânica. Instituto de Ciências Biológicas. Universidade de Brasília, Brasília, DF, 2016.

O babaçu (Attalea spp.) é uma palmeira nativa com ampla distribuição no Brasil, sendo encontrado nas regiões Norte, Nordeste, Sudeste e Centro-Oeste. Constitui um recurso natural de elevada importância no nordeste brasileiro e é um dos principais produtos extrativistas do país. A identificação taxonômica do conjunto de espécies de babaçu é complexa, e não há consenso entre os diversos autores, por isso, esse conjunto de espécies é denominado "complexo babaçu". Considerando-se as divergências taxonômicas acerca do gênero Attalea e a importância da correta classificação das espécies para programas de melhoramento e conservação, foi proposta a caracterização da anatomia foliar e o estudo com DNA barcode de sete espécies do complexo babaçu que ocorrem no Brasil, a fim de fornecer dados anatômicos e moleculares discriminatórios que possam subsidiar a taxonomia. A anatomia foliar das sete espécies estudadas do gênero Attalea foi altamente informativa. Os dados gerados podem auxiliar na identificação das espécies, assim como em sua classificação taxonômica. Os marcadores $r b c L$, $\operatorname{trnL}$ e matK não apresentaram resolução suficiente para a discriminação das espécies. Os marcadores $p s b A$-trn $H$, ITS e PRK apresentaram resultados potencialmente satisfatórios para serem usados com regiões barcode para espécies de Attalea. $\mathrm{O}$ uso de marcadores barcode em espécies do gênero Attalea necessita ser aprimorado, tanto no estabelecimento de protocolos de extração, PCR e sequenciamento eficientes quanto na escolha e combinação dos marcadores utilizados.

Palavras-chave: Attalea, Babaçu, Anatomia foliar, DNA barcode 


\begin{abstract}
DA MATA, Lorena Ramos. Molecular and anatomic characterization of babassu complex (Attalea spp., Arecaceae) 2016. 149p. Dissertação (Mestrado) - Departamento de Botânica. Instituto de Ciências Biológicas. Universidade de Brasília, Brasília, DF, 2016.

The babassu (Attalea spp.) is a palm tree native to Brazil with wide distribution, being found in the North, Northeast, Southeast and Central West regions. The plant is a natural resource of great importance in northeastern Brazil and one of the main extractive products in the country. The identification and taxonomy of babassu species is difficult and there is no taxonomic consensus among many authors, so this group of species is known as the "babassu complex". Considering the taxonomic problems in Attalea and the importance of proper classification of species for breeding and conservation programs, we proposed to characterize the leaf anatomy and apply DNA barcoding techniques to seven species of the babassu complex occurring in Brazil, with the aim of providing discriminatory anatomical and molecular data to support current taxonomy. The leaf anatomy of seven Attalea species studied was highly informative. The data generated can assist greatly in identifying the species within the current taxonomic framework. The DNA loci $r b c L$, trnL and $m a t K$ showed insufficient resolution for discrimination of species. The $p s b A$-trnH markers, ITS and PRK showed potentially satisfactory results for discriminating Attalea species. The use of DNA barcodes in Attalea, however, needs to be improved, both in the optimization of DNA extraction, PCR and sequencing protocols, as well as the choice and combination of markers used.
\end{abstract}

Key words : Attalea, babassu, leaf anatomy, DNA barcode 


\section{ÍNDICE DE TABELAS}

Tabela 1. Classificação da espécie Attalea speciosa (Mart. ex. Spreng.). com os respectivos autores e datas (CAVALLARI et al., 2016)

Tabela 2. Tipos de híbridos de A. x teixeirana (Bondar.) com suas respectivas características 12

Tabela 3. Tabela de substituições nucleotídicas .17

Tabela 4. Tabela de amostras utilizadas nas análises de anatomia foliar. .25

Tabela 5. Tabela de amostras de espécies babaçu coletadas com suas respectivas origens utilizadas neste estudo 50

Tabela 6. Amostras de herbário utilizadas no estudo. .51

Tabela 7. Sequências retiradas do GenBank para a construção das árvores .51

Tabela 8. Sequência e referência dos primers utilizados nas amplificações por PCR .52

Tabela 9. Porcentagem de bases das sequências analisadas por marcador utilizado. Cálculos realizados no programa MEGA 6.06.

Tabela 10. Porcentagem de bases púricas, bases pirimídicas, transições, transversões. Razão das taxas de transições/transversões, das taxas de transversões/transições por marcadores com seus respectivos valores de viés. Cálculos realizados no programa MEGA 6.06 60

Tabela 11. Número total de bases das sequências por marcador. Número total de sítios conservados, de sítios vaiáveis e de sítios filogeneticamente informativos por marcador. Cálculos realizados no programa MEGA 6.06....

Tabela 12. Probabilidade de substituições nucleotídicas, em valores percentuais, calculadas para todas as amostras, por loco, de acordo com o modelo de substituição de Tamura-Nei (2004). Valores em negrito indicam transições, em itálico transversões, cálculos realizados no programa MEGA 6.06. 61

Tabela 13. Médias das distâncias par a par das amostras de Attalea e Cocos nucifera (outgroup)...62 Tabela 14. Sumário das características das sequências e das estatísticas das árvores (análises de máxima parcimônia). .73 


\section{ÍNDICE DE FIGURAS}

Figura 1. Attalea speciosa (Mart. ex. Spreng.). A. Palmeira na mata (Fonte: Marcelo Mattos Cavallari, 2014). B. Infrutescência (Fonte: Marcelo Mattos Cavallari, 2014). C. Secção de frutos contendo de três a seis sementes (Fonte: Márcia de Faria, 2014).

Figura 2. Attalea barreirensis (Glassman.). A. Palmeira sem estipe (MARTINS, 2013). B. Infrutescência (MARTINS, 2013). C. Fruto seccionado contendo uma semente (MARTINS, 2013).

Figura 3. Attalea eichleri (Drude A. J. Hend.). A. Palmeira sem estipe (MARTINS, 2013). B. Infrutescência (MARTINS, 2013). C. Frutos secos seccionados contendo quatro e cinco sementes (MARTINS, 2013)

Figura 4. Attalea funifera (Mart.). A. Palmeira (SILVEIRA, 2013). B. Infrutescência (SILVEIRA, 2013). C. Fruto seco seccionado com espaço de uma semente (MARTINS, 2013). D. Piaçava utilizada na fabricação de vassouras (GUIMARÃES, 2012). .8

Figura 5. Attalea maripa (Aubl. Mart.). A. Palmeira (Fonte: Afonso Rabelo, 2013). B. Infrutescência (MARTINS, 2013). C. Frutos secos inteiros e seccionados, contendo sementes variando de 1 a 3 (Fonte: Afonso Rabelo, 2013) 9

Figura 6. Attalea phalerata (Mart. ex Spreng.). A. Palmeira (Fonte: Marcelo Mattos Cavallari, 2014). B. Infrutescência (MARTINS, 2013). C. Fruto seco seccionado, contendo 3 sementes (MARTINS, 2013)...... 10

Figura 7. Attalea vitrivir (Burret.). A. Palmeira (NEVES, 2013). B. Infrutescência (Martins, 2013). C. Fruto seco inteiro (NEVES, 2013). D. Fruto seccionado com 7 sementes (NEVES, 2013)..........11

Figura 8 . Attalea x teixeirana (Bondar.). A. "pindova" (Fonte: Marcelo Mattos Cavallari, 2014). B. "speciosa baixa" (Fonte: Marcelo Mattos Cavallari, 2014). C. "perinã" (Fonte: Marcelo Mattos Cavallari, 2014). D. "eichleri grande" (Fonte: Marcelo Mattos Cavallari, 2014)...........................12

Figura 9. Anatomia foliar de Attalea speciosa (Mart. ex Spreng.).................................................28

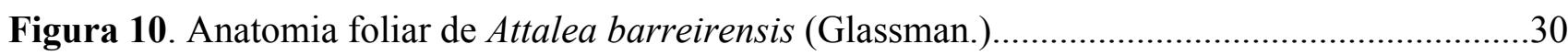

Figura 11. Anatomia foliar de Attalea eichleri (Drude A. J. Hend.)...............................................32

Figura 12. Anatomia foliar de Attalea funifera (Mart.)..............................................................34

Figura 13. Anatomia foliar de Attalea maripa (Aubl. Mart.)........................................................36

Figura 14. Anatomia foliar de Attalea phalerata (Mart. ex Spreng.)................................................38

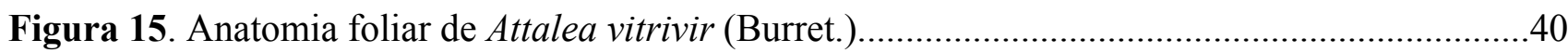

Figura 16. Formas das secções foliares transversais onde se encontram as nervuras principais e formas das margens foliares das espécies Attalea estudadadas. 
Figura 17. Dendograma gerado pelo método UPGMA para o coeficiente de JACCARD para os dados morfológicos obtidos através da anatomia foliar das espécies $A$. speciosa, A barreirensis, $A$. eichleri, A. funifera, A. maripa, A. phalerata e A. vitrivr.

Figura 18. Eficácia da amplificação das sequências por marcador utilizado para as espécies $A$. speciosa, A. barreirensis, A. eichleri e A. funifera.

Figura 18 (continuação). Eficácia da amplificação das sequências por marcodor utilizado para as espécies A. maripa, A. phalerata, A. vitrivir e A. teixeirana..... .59

Figura 19. Distâncias médias K2P intraespecíficas e interespecíficas por espécie de Attalea para o marcador psbA-trnH.

Figura 20. Distribuição das frequências das distâncias médias K2P intraespecíficas e interespecíficas para o marcador $p s b A$-trnH.....

Figura 21. Distâncias médias K2P intraespecíficas e interespecíficas por espécies de Attalea para o marcador PRK

Figura 22. Distribuição das frequências das distâncias médias K2P intraespecíficas e interespecíficas para o marcador PRK 64

Figura 23. Distribuição das frequências das distâncias médias K2P intraespecíficas e interespecíficas para o marcador ITS.

Figura 24. Distribuição das frequências das distâncias médias K2P intraespecíficas e interespecíficas para o marcador ITS .65

Figura 25. Árvore filogenética de Inferência Bayesiana gerada a partir de sequências do gene $m a t K$, mostrando relações entre algumas espécies do gênero Attalea. Todos os valores de probabilidade posterior foram significativos (maiores que 90\%). Cocos nucifera (HQ265564.1) foi utilizado como outgroup.....

Figura 26. Árvore filogenética de Inferência Bayesiana gerada a partir de sequências do gene $r b c L$, mostrando relações entre algumas espécies do gênero Attalea. Todos os valores de probabilidade posterior foram significativos (maiores que 90\%). Cocos nucifera (AY012507.1) foi utilizado como outgroup.

Figura 27. Árvore filogenética de Inferência Bayesiana gerada a partir de sequências do gene $\operatorname{trn} L$, mostrando relações entre algumas espécies do gênero Attalea. Todos os valores de probabilidade posterior foram significativos (maiores que 90\%). Cocos nucifera (AM113647.1) foi utilizado como outgroup.

Figura 28. Árvore filogenética de Inferência Bayesiana gerada a partir de sequências do gene psbAtrnH, mostrando relações entre algumas espécies do gênero Attalea. Todos os valores de probabilidade posterior foram significativos (maiores que $90 \%$ ). O colchete azul destaca o clado com as espécies $A$. funifera e $A$. phalerata. O colchete vermelho destaca uma amostra de A. phalerata de herbário. Cocos nucifera (GQ435464.1) foi utilizado como outgroup...........................................70 
Figura 29. Árvore filogenética de Inferência Bayesiana gerada a partir de sequências do gene ITS, mostrando relações entre algumas espécies do gênero Attalea. A maioria dos valores da probabilidade posterior foram significativos (maiores que 90\%) O colchete vermelho destaca o clado com as espécies $A$. speciosa, $A$. eichleri e $A$. vitrivir. O colchete azul destaca o clado com as espécies A. funifera e $A$. barreirensis. O colchete verde destaca o clado com a espécie A. phalerata. Cocos nucifera (HQ265515.1) foi utilizado como outgroup.

Figura 30. Árvore filogenética de Inferência Bayesiana gerada a partir de sequências do gene PRK, mostrando relações entre algumas espécies do gênero Attalea. A maioria dos valores da probabilidade posterior foram significativos (maiores que $90 \%$ ). O colchete vermelho destaca o clado com a espécie $A$. maripa. O colchete azul destaca o clado com a espécie A. funifera. Os colchetes verde e amarelo destacam os clados com a espécie A. barreirensis. Cocos nucifera (AY601235.1) foi utilizado como outgroup. 72

Figura 31. Árvores filogenéticas de MP geradas a partir de sequências do marcador $p s b A$-trnH. A árvore da esquerda foi gerada sem considerar os gaps, enquanto que a árvore da direita foi gerada com a atribuição numérica dos gaps. Cocos nucifera (GQ 435464.1) foi utilizado como outgroup. O valor indicado acimo dos ramos indica a porcentagem de bootstrap..... 


\section{ÍNDICE DE ANEXOS}

\section{Anexo I}

Tabela 15. Dados morfológicos analisados como presença (1) e ausência (0) das características de cada uma das sete espécies de Attalea.

\section{Anexo II}

Tabela 16. Amostras de Attalea com suas respectivas informações de coleta..... 93

\section{Anexo III}

Tabela 17. Estimativa de distâncias par a par entre as sequências de Attalea geradas para o marcador rbch (Kimura 2P). 96

Tabela 18. Estimativa de distâncias par a par entre as sequências de Attalea geradas para o marcador matK (Kimura 2P)

Tabela 19. Estimativa de distâncias par a par entre as sequências de Attalea geradas para o marcador trnL (Kimura 2P). 101

Tabela 20. Estimativa de distâncias par a par entre as sequências de Attalea geradas para o marcador $p s b A$-trnH (Kimura 2P). 103

Tabela 21. Estimativa de distâncias par a par entre as sequências de Attalea geradas para o marcador ITS (Kimura 2P).

Tabela 22. Estimativa de distâncias par a par entre as sequências de Attalea geradas para o marcador PRK (Kimura 2P). 106

\section{Anexo IV}

Figura 32. Árvore filogenética de Máxima Parcimônia gerada a partir de sequências do gene matK, mostrando relações entre espécies do gênero Attalea. O valores de bootstrap significativos (maior que 50\%) estão representados nos nós. Cocos nucifera (HQ265564.1) foi utilizado como outgroup. As árvores de consenso de bootstrap foram inferidas a partir de 1.000 repetições. 110

Figura 33. Árvore filogenética de Máxima Parcimônia gerada a partir de sequências do gene $r b c L$, mostrando relações entre espécies do gênero Attalea. O valores de bootstrap significativos (maior que 50\%) estão representados nos nós. Cocos nucifera (AY012507.1) foi utilizado como outgroup. As árvores de consenso de bootstrap foram inferidas a partir de 1.000 repetições.

Figura 34. Árvore filogenética de Máxima Parcimônia gerada a partir de sequências do gene $\operatorname{trn} L$, mostrando relações entre espécies do gênero Attalea. O valores de bootstrap significativos (maior que 50\%) estão representados nos nós. Cocos nucifera (AM113647.1) foi utilizado como outgroup. As árvores de consenso de bootstrap foram inferidas a partir de 1.000 repetições. 
Figura 35. Árvore filogenética de Máxima Parcimônia gerada a partir de sequências do gene ITS, mostrando relações entre espécies do gênero Attalea. O valores de bootstrap significativos (maior que 50\%) estão representados nos nós. Cocos nucifera (HQ265515.1) foi utilizado como outgroup. As árvores de consenso de bootstrap foram inferidas a partir de 1.000 repetições. 113

Figura 36. Árvore filogenética de Máxima Parcimônia gerada a partir de sequências do gene PRK, mostrando relações entre espécies do gênero Attalea. O valores de bootstrap significativos (maior que 50\%) estão representados nos nós. Cocos nucifera (AY601235.1) foi utilizado como outgroup. As árvores de consenso de bootstrap foram inferidas a partir de 1.000 repetições. 114

Figura 37. Árvore filogenética de Máxima Verossimilhança inferida a partir de sequências do gene matK, mostrando relações entre algumas espécies do gênero Attalea. Os valores significativos (maior que 50\%) de bootstrap (1.000 repetições) estão representados na na árvore. Cocos nucifera (HQ265564.1) foi utilizado como outgroup.

Figura 38. Árvore filogenética de Máxima Verossimilhança inferida a partir de sequências do gene $r b c L$, mostrando relações entre algumas espécies do gênero Attalea. Os valores significativos (maior que $50 \%$ ) de bootstrap (1.000 repetições) estão representados na árvore. Cocos nucifera (AY012507.1) foi utilizado como outgroup. 116

Figura 39. Árvore filogenética de Máxima Verossimilhança inferida a partir de sequências do gene $\operatorname{trnL}$, mostrando relações entre algumas espécies do gênero Attalea. Os valores significativos (maior que 50\%) de bootstrap (1.000 repetições) estão representados na na árvore. Cocos nucifera (AM.113647.1) foi utilizado como outgroup....

Figura 40. Árvore filogenética de Máxima Verossimilhança inferida a partir de sequências do gene psbA-trnH, mostrando relações entre algumas espécies do gênero Attalea. Os valores significativos (maior que 50\%) de bootstrap (1.000 repetições) estão representados estão representados na árvore. Cocos nucifera (GQ435464.1) foi utilizado como outgroup. 118

Figura 41. Árvore filogenética de Máxima Verossimilhança inferida a partir de sequências do gene PRK, mostrando relações entre algumas espécies do gênero Attalea. Os valores significativos (maior que 50\%) de bootstrap (1.000 repetições) estão representados na árvore. Cocos nucifera (AY601235.1) foi utilizado como outgroup. 119

Figura 42. Árvore filogenética de Máxima Verossimilhança inferida a partir de sequências do gene ITS, mostrando relações entre algumas espécies do gênero Attalea. Os valores significativos (maior que $50 \%$ ) de bootstrap (1.000 repetições) estão representados na árvore. Cocos nucifera (HQ265515.1) foi utilizado como outgroup. 120

\section{Anexo V}

Sequências de matK. 121

Sequências de $r b c L$ .127

Sequências de $\operatorname{trnL}$ 132 
Sequências de ITS.

Sequências de $p s b A$-trn $H$...

Sequências de PRK. 


\section{SUMÁRIO}

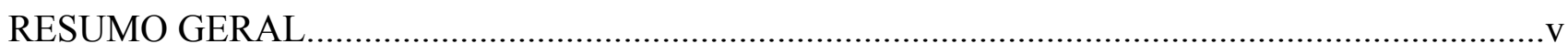

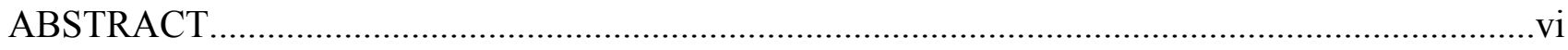

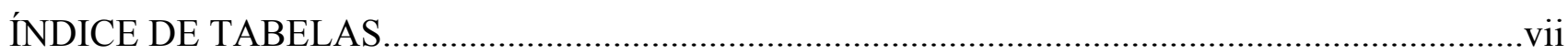

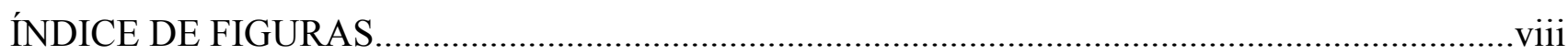

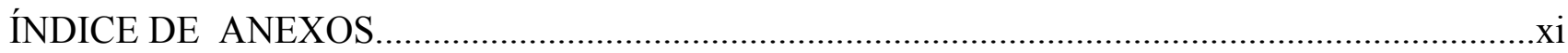

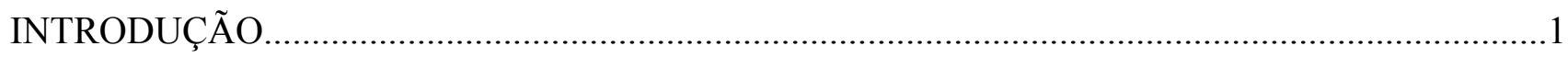

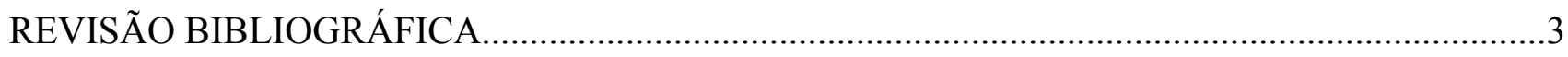

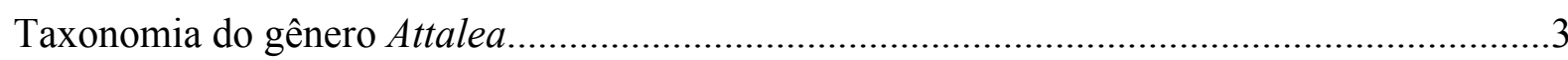

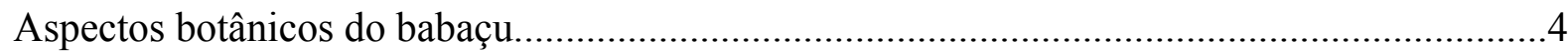

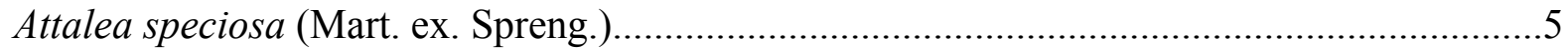

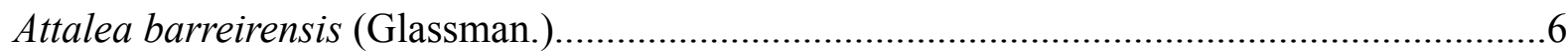

Attalea eichleri (Drude A. J. Hend.)................................................

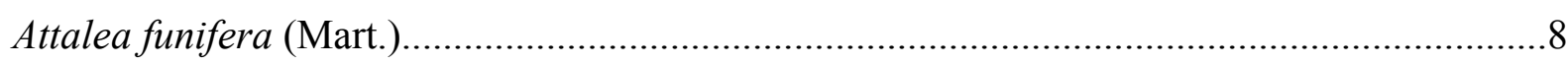

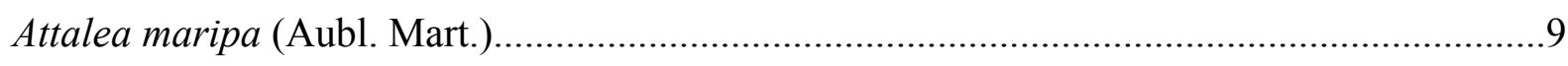

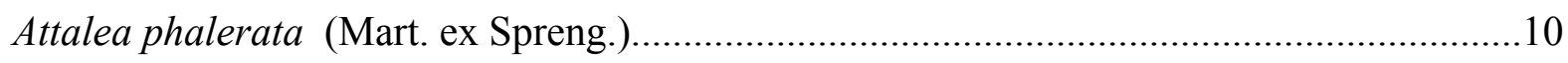

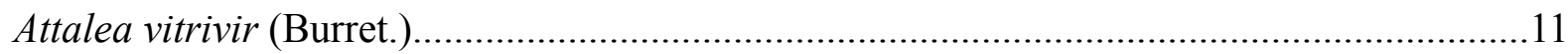

Híbrido - Attalea x teixeirana (Bondar.)....................................................................... 11

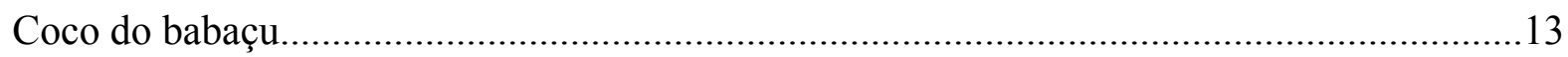

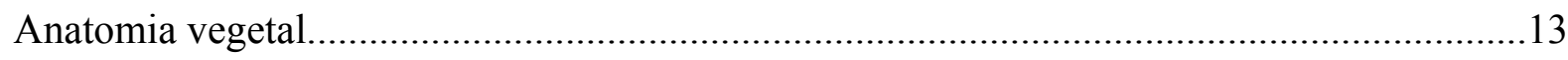

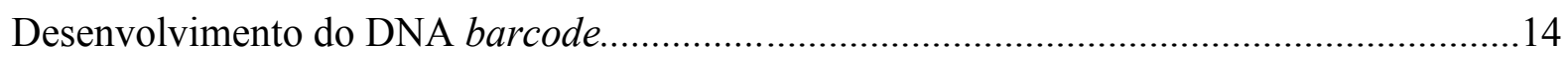

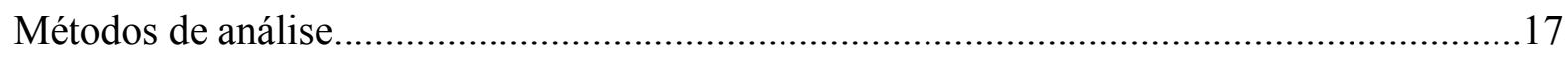

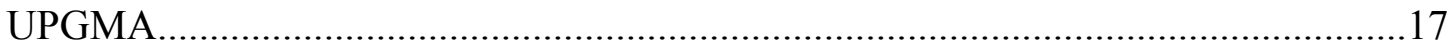

Modelo de Kimura 2-parâmetros (Kimura-2P)...................................................... 17

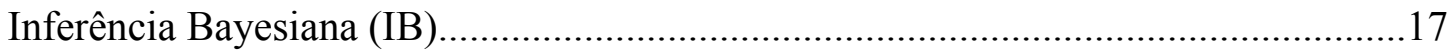

Máximo Verossimilhança (MV) ................................................................... 18

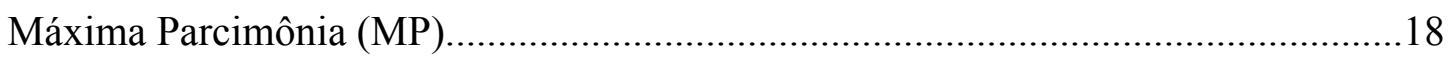

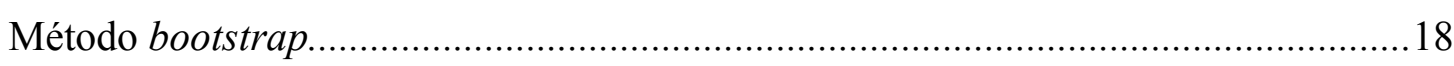

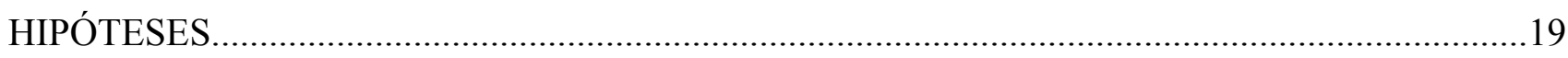

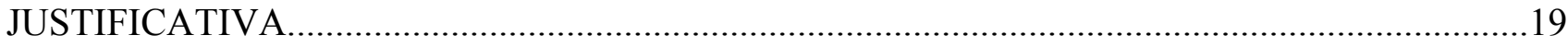

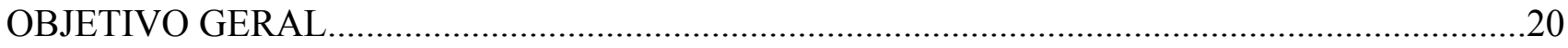

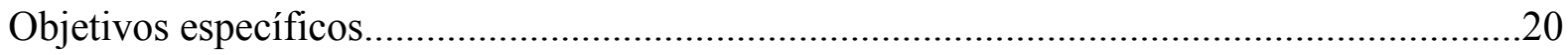




\section{CAPÍTULO 1 - ANATOMIA FOLIAR VEGETAL NO AUXÍlio À TAXONOMIA DO COMPLEXO BABAÇU (Attalea spp.)}

RESUMO.

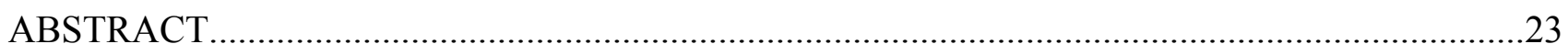

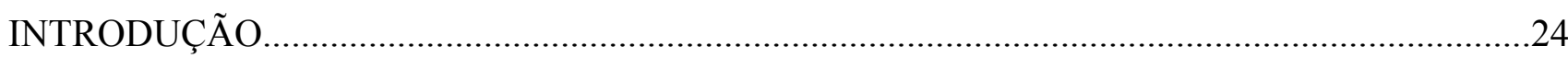

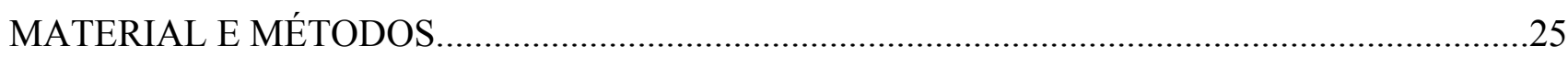

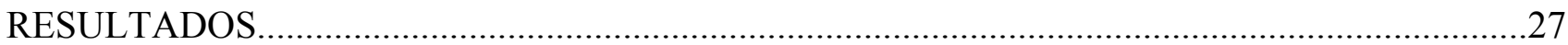

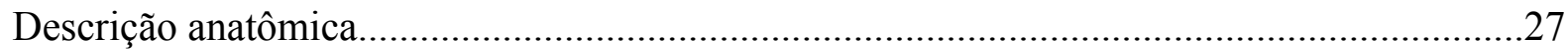

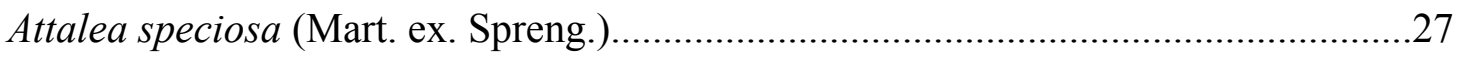

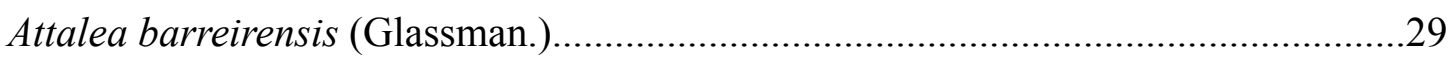

Attalea eichleri (Drude A. J. Hend.).............................................. 31

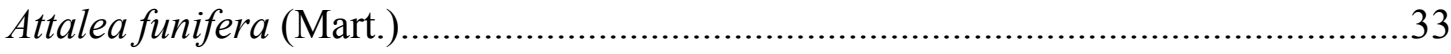

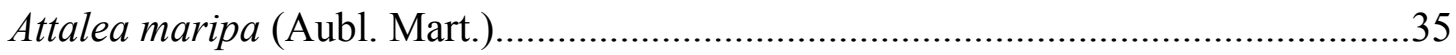

Attalea phalerata (Mart. ex Spreng.)..........................................................................

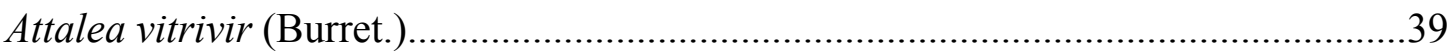

DISCUSSÃO

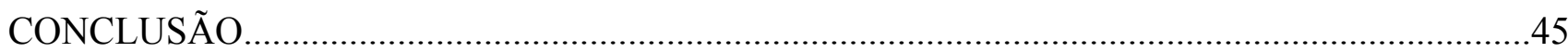

CAPÍTULO 2 - APLICAÇÃO E AVALIAÇÃO DE DNA BARCODE EM ESPÉCIES DO COMPLEXO BABAÇU (Attalea spp.)

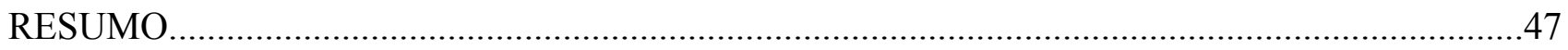

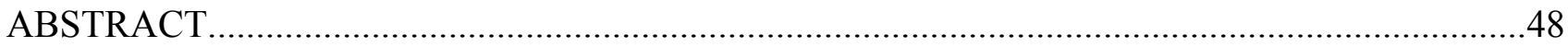

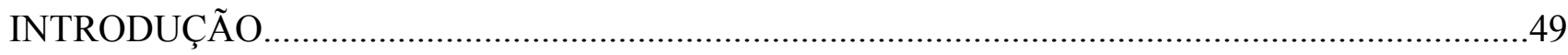

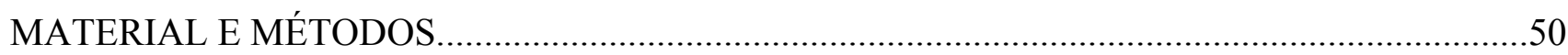

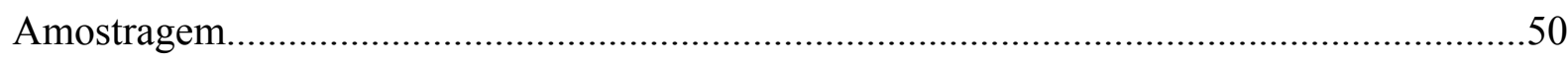

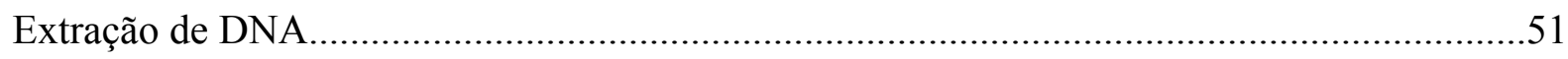

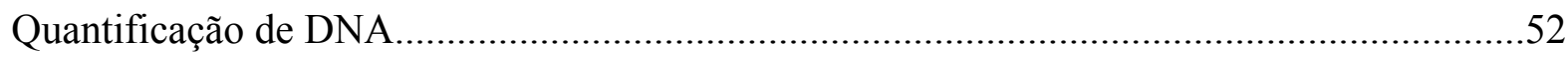

Reações de PCR (Polymerase Chain Reaction)....................................................................52

Purificação dos produtos de PCR com as enzimas Exonuclease I (EXO I) e Shrimp Alkaline

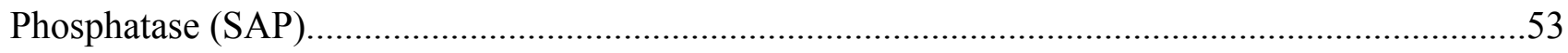

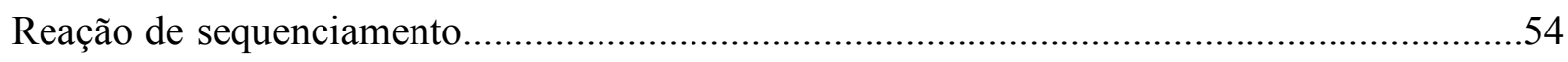

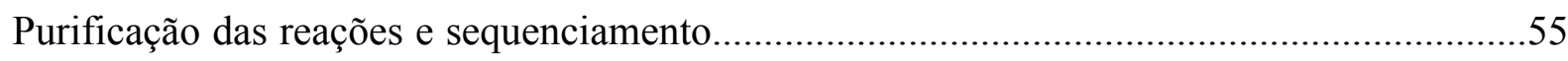

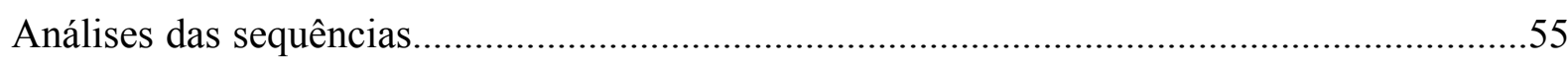

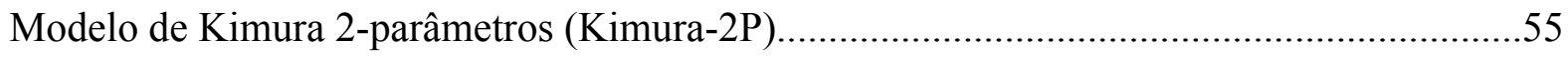

Cálculo das Distâncias Intraespecíficas e Interespecíficas...................................................55 
Construção das árvores de Inferência Bayesiana (IB), Máxima Parcimônia (MP) e Máxima

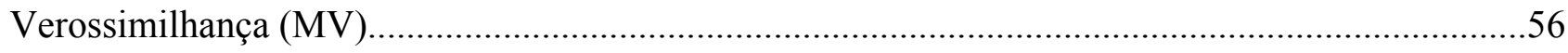

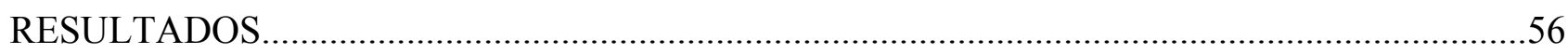

Amplificação e sequenciamento das amostras de Attalea ....................................................56

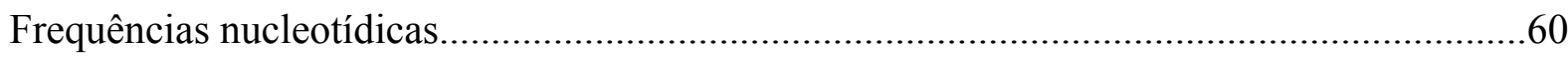

Cálculo das distâncias Intraespecíficas e Interespecíficas.....................................................62

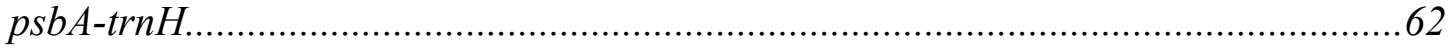

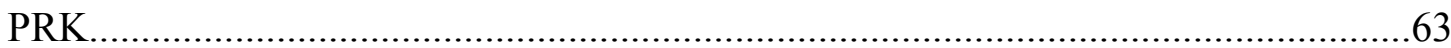

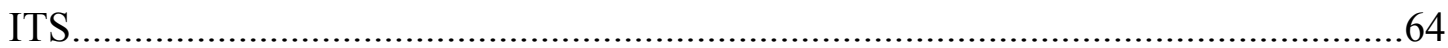

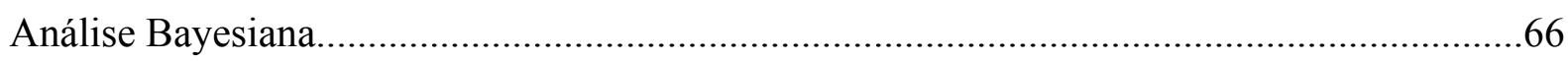

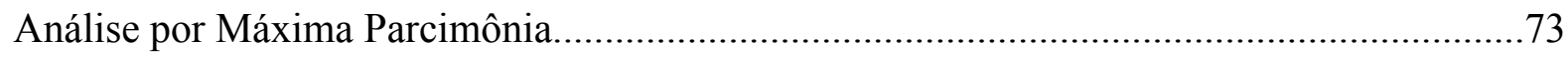

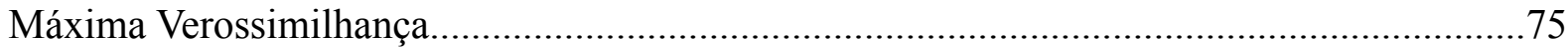

DISCUSSÃO

Amplificação e sequenciamento das amostras de Attalea .....................................................75

Distâncias Intraespecíficas e Interespecíficas (Kimura 2P)................................................76

Árvores de barcode com os métodos de IB, MP e MV..................................................... 77

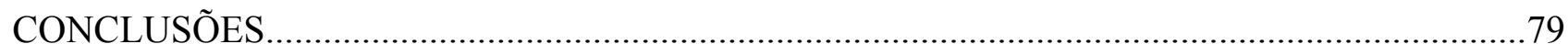

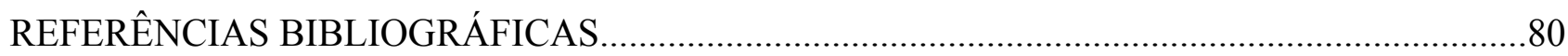

ANEXOS 


\section{INTRODUÇÃO}

O babaçu (Attalea spp.) é uma palmeira endêmica no Brasil de ampla distribuição, sendo encontrado nas regiões Norte, Nordeste, Sudeste e Centro-Oeste, abrangendo desde o Sul da Bacia Amazônica até a vegetação típica dos cerrados. Os estados do Maranhão, Piauí e Tocantins concentram as maiores extensões de matas onde predominam os babaçuais, sendo no Maranhão onde se encontra a maior concentração e exploração (LORENZI et al., 1996; COELHO, 2002; MEIRELLES, 2004; ARAÚJO, 2008; MATOS et al., 2010). Além do Brasil, as palmeiras de babaçu são nativas de Trinidad e Tobago, Colômbia, Venezuela, Suriname, Guiana, Guiana Francesa, Equador, Peru, Bolívia, Paraguai e Peru (HENDERSON et al., 1995 e LORENZI et al., 1996; BALICK \& PINHEIRO, 2000; PINTAUD, 2008; CHOO et al., 2010; CORRÊA et al., 2012, BAKER \& DRANSFIELD, 2016). O babaçu constitui um recurso natural de elevada importância no nordeste brasileiro e é um dos principais produtos extrativistas do país, contribuindo, de maneira significativa, para a economia de alguns estados da Federação (LIMA et al., 2006; DE MESQUITA, 2015).

O principal produto extraído do babaçu é a amêndoa. Dados do IBGE de 2011 registram que cerca de 100 mil toneladas destas amêndoas são comercializadas no Brasil anualmente (IBGE, 2013). As amêndoas são extraídas manualmente em um sistema caseiro tradicional e de subsistência, cujas responsáveis são popularmente conhecidas como as "quebradeiras de babaçu”, geralmente mulheres acompanhadas de suas crianças (FIGUEIREDO, 2005). A amêndoa quando verde fornece um leite nutritivo e quando madura, o óleo para uso doméstico, tendo também utilização industrial para fabricação de produtos de higiene e perfumaria (LORENZI et al., 1996; LORENZI, 2000; CARRAZZA et al., 2012; BRANDÃO et al., 2002). O mercado nacional de óleo tem consumido 5,5 mil toneladas de óleo comestível de babaçu por ano e as indústrias dos segmentos de higiene, limpeza e cosméticos absorvem cerca de 35 mil toneladas anuais de óleo de babaçu bruto (SOUZA et al., 2011). O babaçu também é utilizado na fabricação de artesanatos, casas e paisagismo, podendo fornecer até 64 diferentes produtos (LORENZI, 2000; SANTOS et al., 2008; GONZÁLES-PÉREZ et al., 2012; COLLARES, 2014). No Maranhão, o extrativismo do babaçu está associado à agricultura familiar e se caracteriza por ser ultra-extensiva. A estimativa é de que haja uma área de 4.722 .812 ha efetivamente ocupada e intensiva em mão-de-obra familiar (ALMEIDA, 1995).

A prática da agricultura rudimentar e nômade e a proliferação de projetos agropecuários e industriais podem levar a erradicação destas palmeiras (SANTOS et al., 2008). Além disso, 
provocam a diminuição da produtividade ou a redução das reservas de babaçu em locais de maior densidade demográfica (SANTOS et al., 2008).

A conservação e o uso sustentável dos babaçuais são importantes para a preservação deste recurso florestal e também para a economia das regiões endêmicas do gênero. Para fins de conservação ex situ das espécies de babaçu e da significativa representatividade da variabilidade genética que elas apresentam, é necessário a criação de novos Bancos Ativos de Germoplasma (BAGs) e a manutenção dos já existentes. A conservação do germoplasma permite acesso a genes que podem ser utilizados como fonte de variabilidade em programas de melhoramento, assim como a reintrodução de material in situ (BESPALHOK et al., 2014). Na Embrapa Meio-Norte (Teresina-PI) encontra-se um BAG de aproximadamente 2,5 ha com germoplasma de babaçu, distribuído em duas áreas. Uma delas foi implantada em 1985, atualmente conta com cerca de 140 plantas provenientes das regiões de Tocantins, Maranhão, Teresina e Ceará. A outra área contém germoplasma plantado em 1990 e tem cerca de 300 plantas provenientes da Bolívia, Tocantins, Maranhão, Bahia e Minas Gerais. A partir de 2002, a Embrapa Meio-Norte iniciou um programa de revitalização deste BAG, com o objetivo de cadastrar os acessos e caracterizar as plantas e frutos (SITTOLIN et al., 2008).

A identificação taxonômica do conjunto de espécies de babaçu é complexa, e não há consenso entre os diversos autores, por isso, esse conjunto de espécies é denominado "complexo babaçu". O desenvolvimento de híbridos naturais entre as espécies, o reduzido número de coletas e a limitada quantidade de estudos anatômicos, morfológicos e moleculares sobre o gênero dificultam a correta identificação taxonômica dessas espécies (ANDERSON \& BALICK, 1988; PINTAUD, 2008).

Considerando-se as divergências taxonômicas acerca do gênero Attalea e a importância da correta identificação das espécies para programas de melhoramento e conservação, propõe-se a caracterização da anatomia foliar e o estudo com DNA barcode de sete espécies do complexo babaçu que ocorrem no Brasil. Esses estudos devem fornecer dados anatômicos e moleculares discriminatórios que possam subsidiar a taxonomia do gênero Attalea. 


\section{REVISÃO BIBLIOGRÁFICA}

\section{Taxonomia do gênero Attalea}

A taxonomia do gênero Attalea é dificultada pela fenologia sazonal destas espécies. A mesma palmeira, dependendo da estação, pode apresentar diferenças morfológicas importantes, como por exemplo nas inflorescências. Além disso, o tamanho do material botânico dificulta a preparação e manutenção das exsicatas (MEDEIROS-COSTA, 1985; PINTAUD, 2008). Muitas espécies foram descritas somente recentemente e são pouco conhecidas. Pintaud (2008) comparou a classificação de três trabalhos de taxonomia (HENDERSON et al., 1995; GLASSMAN, 1999; GOVAERTS \& DRANSFIELD, 2005), e verificou que o números de espécies do gênero variou de 29 a 67 entre os autores, enquanto que o número de espécies consenso foi somente de 20.

A principal espécie, Attalea speciosa, foi identificada por diferentes autores e classificada com diferentes nomes. A evolução desta classificação está explicitada na Tabela 1. Martius, o primeiro a descrever a espécie, denominou-a Attalea speciosa em 1826 (GLASMAN, 1999). O próprio Martius, em 1844, designou-a como Orbignya phalerata.

Drude, em 1881, denominou esta espécie como Orbignya lydiae. Barbosa Rodrigues, em 1891, considerou como Orbignya speciosa, e, em 1898, como Orbignya martiana. O mesmo Barbosa Rodrigues, em 1903, percebeu que suas duas classificações tratavam-se da mesma espécie (ANDERSON \& BALICK, 1988; GLASMAN, 1999; PINTAUD, 2008; CAVALLARI et al., 2016).

Em 1932, Orbignya speciosa passou a ser considerada sinônima de Orbignya martiana e de Attalea speciosa, passando a ser denominada como Orbignya barbosiana. Posteriormente, em 1988, Anderson e Balick estudaram a espécie e consideraram o nome Orbignya martiana como válido e descartaram o nome Orbignya speciosa, mas comparando com a descrição e ilustrações de Orbignya phalerata de 1844, eles propuseram novamente o nome Orbignya phalerata (CAVALLARI et al., 2016).

Dransfield e colaboradores (2005), considerando muitos trabalhos, apresentaram uma nova classificação filogenética para Arecaceae, e consideraram Orbignya phalerata como sinônima de Attalea speciosa. Esta publicação foi uma prévia da nova classificação de palmeiras publicada na segunda edição de Genera Palmarum (DRANSFIELD et al., 2008; CAVALLARI et al., 2016).

Apesar das recentes publicações sobre o gênero, a taxonomia de Attalea ainda é confusa. Assim como Attalea speciosa, outras espécies do gênero também apresentam dificuldade para a 
correta identificação e classificação. A correta identidade e de muitas espécies ainda precisam ser averiguadas. Novos estudos, incluindo análises de DNA, podem ajudar a solucionar as dificuldades e inconsistências de classificação taxonômica remanescentes. Esses trabalhos citados são de grande importância, pois procuram esclarecer a taxonomia do gênero Attalea (CAVALLARI et al., 2016).

Tabela 8. Classificação da espécie Attalea speciosa com os respectivos autores e datas (CAVALLARI et al., 2016).

\begin{tabular}{|c|c|c|c|}
\hline Autor & Data & Nome & Referência \\
\hline Martius & 1826 & Attalea speciosa & GLASMAN, 1999 \\
\hline Martius & 1844 & Orbignya phalerata & GLASMAN, 1999 \\
\hline Drude & 1881 & Orbignya lydiae & GLASMAN, 1999 \\
\hline Barbosa Rodrigues & 1891 & Orbignya speciosa & GLASMAN, 1999 \\
\hline Barbosa Rodrigues & 1898 & Orbignya martiana & $\begin{array}{l}\text { ANDERSON \& BALICK, 1988; } \\
\text { GLASMAN, } 1999 \text { e PINTAUD, } \\
2008\end{array}$ \\
\hline \multirow[t]{2}{*}{ Barbosa Rodrigues } & 1903 & $\begin{array}{l}\text { Orbignya martiana = } \\
\text { Orbignya speciosa }\end{array}$ & GLASMAN, 1999 \\
\hline & 1932 & $\begin{array}{l}\text { Orbignya speciosa }= \\
\text { Orbignya martiana }=\text { Attalea } \\
\text { speciosa } \\
\rightarrow \text { Orbignya barbosiana }\end{array}$ & GLASMAN, 1999 \\
\hline Anderson e Ballick & 1988 & Orbignya phalerata & ANDERSON \& BALICK, 1988 \\
\hline Govaerts \& Dransfield & 2005 & Attalea speciosa & $\begin{array}{l}\text { GOVAERTS \& DRANSFIELD, } \\
2005\end{array}$ \\
\hline
\end{tabular}

\section{Aspectos botânicos do babaçu}

A família Arecaceae apresenta cerca de 1.500 espécies distribuídas em mais de 200 gêneros, popularmente chamadas palmeiras (REITZ, 1974; HENDERSON et al., 1995; LORENZI et al., 1996). Attalea é um gênero da família Arecaceae, composto por cerca de 29 espécies, ainda não totalmente delimitado. Está distribuído principalmente nas regiões tropicais e subtropicais, com poucas espécies nas zonas temperadas quentes (HENDERSON et al.,1995). Várias espécies apresentam hibridização interespecífica, o que representa uma dificuldade para o entendimento do grupo (PINTAUD et al., 2008). 


\section{Attalea speciosa (Mart. ex. Spreng.)}

Attalea speciosa é considerada o babaçu no sentido restrito (Figura 1-A). Trata-se de uma das espécies com maior importância na subsistência de muitas comunidades tradicionais. Tem sido vista como uma das espécies vegetais de maior potencial para a produção do biodiesel (LIMA et al., 2007). É uma palmeira com estipe solitário. A coroa foliar é constituída por 12 a 20 folhas que apresentam pinas, inseridas em diferentes planos, com bráctea peduncular. A raque da folha pode ser curva no ápice e as pinas apresentam nervuras transversais conspícuas. A inflorescência andrógina ramificada ou não ramificada apresenta flores estaminada. A inflorescência estaminada apresenta um número maior de ráquilas que a inflorescência andrógina (MARTINS, 2013). Os frutos possuem de 10-12 cm de comprimento, casca dura, marrom, com polpa seca, farinhenta e de coloração creme na maturidade. Contém de 1-8 sementes oleaginosas (Figura1, B e C).
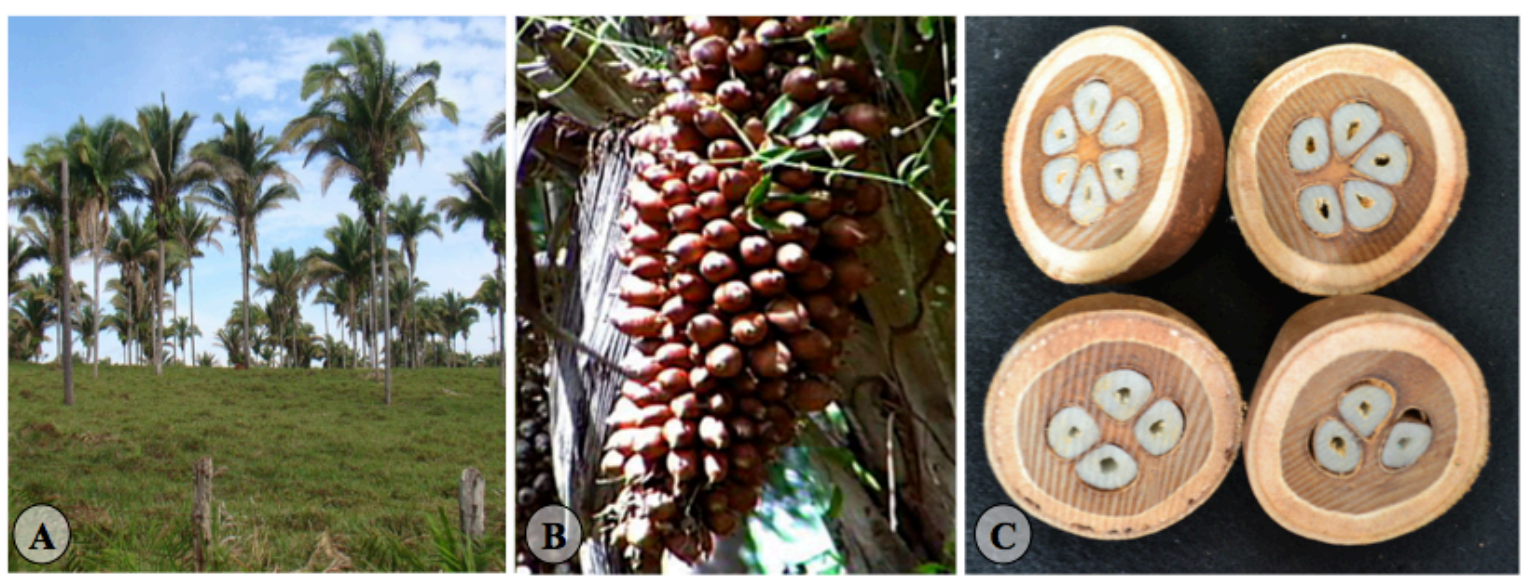

Figura 1. Attalea speciosa (Mart. ex. Spreng.). A. Palmeira na mata (Fonte: Marcelo Mattos Cavallari, 2014). B. Infrutescência (Fonte: Marcelo Mattos Cavallari, 2014). C. Secção de frutos contendo de três a seis sementes (Fonte: Márcia de Faria, 2014).

A área estimada de ocorrência é de $200.000 \mathrm{~km}^{2}$ (MAY et al., 1985). Distribui-se amplamente no sul da região Amazônica, estando além do Brasil presente na Bolívia, Guiana e Suriname (BALICK \& PINHEIRO, 2000). No Brasil está presente nos estados do Maranhão, Piauí, Tocantins, Ceará, Pará, Amazonas, Rondônia, Mato Grosso, Goiás e Minas Gerais (ANDERSON et al., 1991). 


\section{Attalea barreirensis (Glassman.)}

A espécie $A$. barreirensis não apresenta estipe (Figura 2, A). Possui anteras retas, pinas inseridas em grupo e em diferentes planos (MARTINS, 2013). A raque foliar apresenta revestimento esbranquiçado e adpresso. O número de pétalas das flores estaminadas varia de 3-4 (MARTINS, 2013). A espécie é endêmica do Brasil, ocorrendo no Cerrado, nos estados do Piauí, Bahia e Goiás (LEITMAN et al., 2014). Apresenta fruto ovoide, castanho, 6-7 x 4-4,5 cm, contendo número variável de sementes (Figura 2, B e C) (MARTINS, 2013).
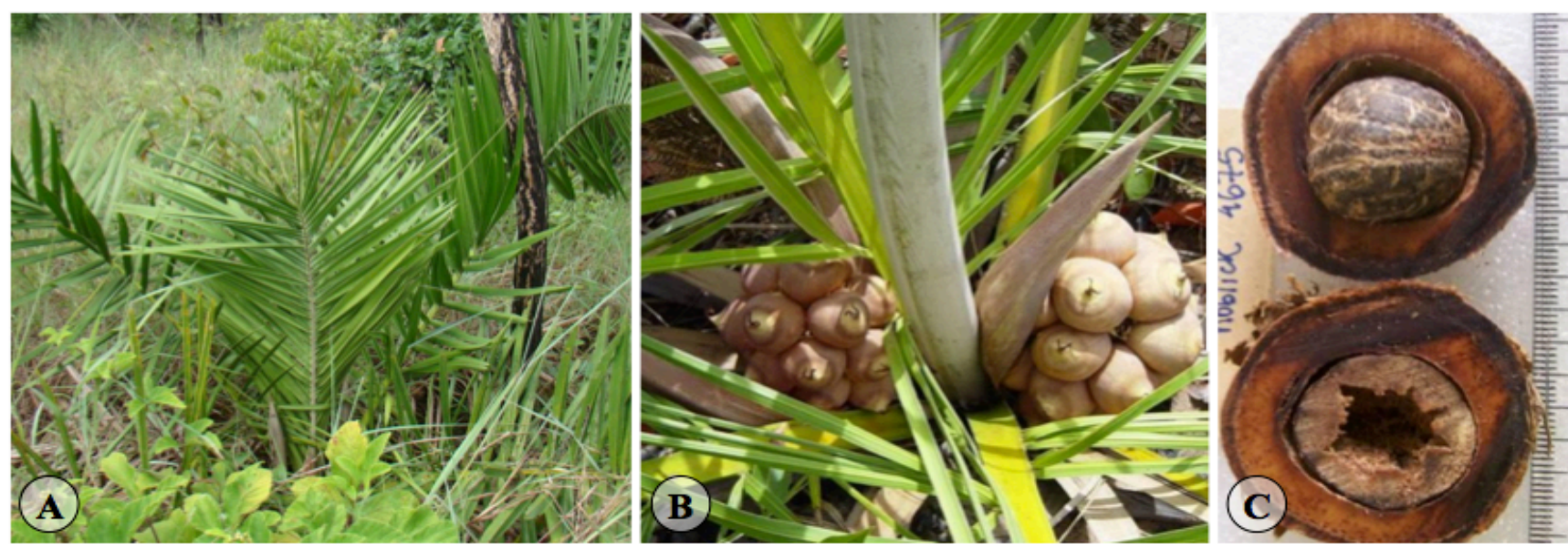

Figura 2. Attalea barreirensis (Glassman.). A. Palmeira sem estipe (MARTINS, 2013). B. Infrutescência (MARTINS, 2013). C. Fruto seccionado contendo uma semente (MARTINS, 2013).

É uma espécie nativa do Brasil. De acordo com Lorenzi e colaboradores (2010) a espécie, até o momento, foi encontrada apenas nas áreas de cerrados não cultivados, estando presente no oeste da Bahia, nordeste de Goiás e sudoeste de Tocantins. 


\section{Attalea eichleri (Drude A. J. Hend.)}

A. eichleri (Drude A. J. Hend.), além de não apresentar estipe (Figura 3, A), apresenta pinas com nervuras secundárias evidentes na face adaxial e nervuras transversais às vezes conspícuas (MARTINS, 2013). As ráquilas e as flores estão dispostas em apenas um lado da raque e das ráquilas, respectivamente. As flores estaminadas apresentam frequentemente duas pétalas; as pétalas muitas vezes dobram-se para dentro, tornando o androceu exposto como uma janela na face lateral da flor. As flores pistiladas podem ocorrer em díades, às vezes pediceladas e com o ovário recoberto por denso tomento esbranquiçado (MARTINS, 2013). Apresenta fruto ovoide, castanho claro amarelado, 5-8 x 3,5-5,5 cm (Figura 3, B e C); podendo conter de 2-7 sementes.
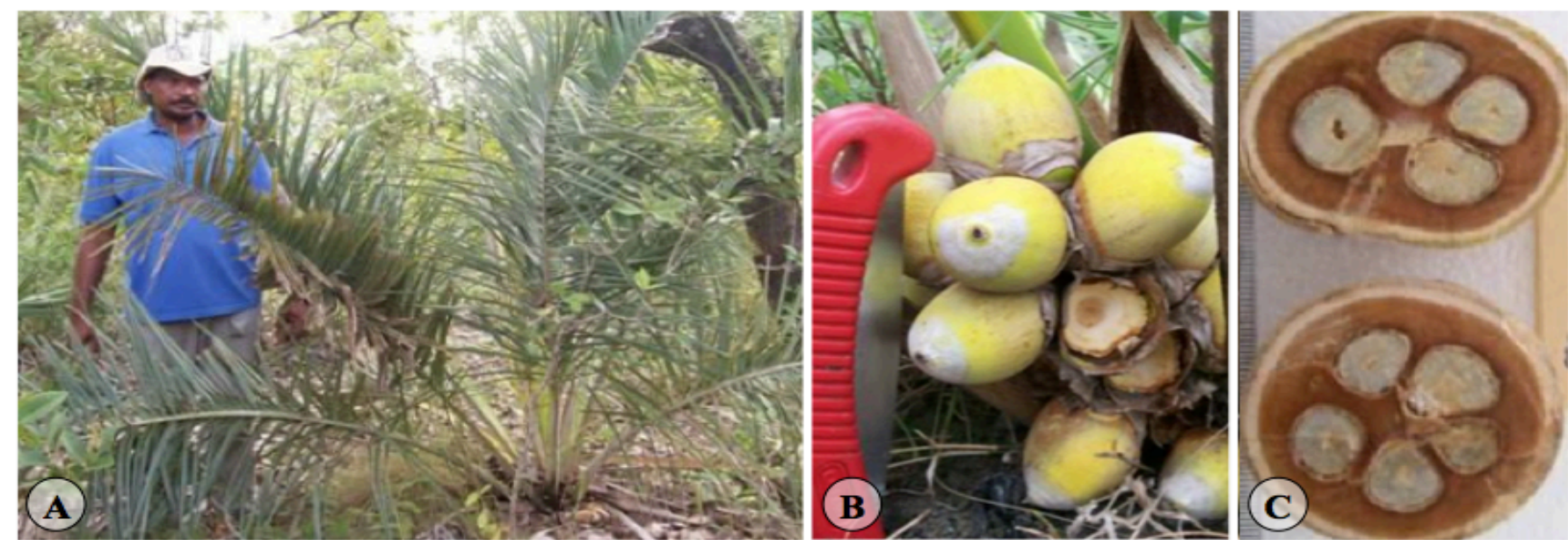

Figura 3. Attalea eichleri (Drude A. J. Hend.). A. Palmeira sem estipe (MARTINS, 2013). B. Infrutescência (MARTINS, 2013). C. Frutos secos seccionados contendo quatro e cinco sementes (MARTINS, 2013).

É uma espécies nativa da Bolívia e do Brasil. Ocorre nas regiões leste e sudoeste do estado do Maranhão e sul do município de Teresina no estado do Piauí (PINHEIRO, 1986). 


\section{Attalea funifera (Mart.)}

A. funifera é uma palmeira conhecida como pena de palma, que atinge de 12 a $5 \mathrm{~m}$ de altura, com até $12 \mathrm{~m}$ de comprimento (Figura 4, A). Sua fibra é usada para fabricação de escovas e vassouras duras (vassoura de piaçava) (Figura 4 - D) (MARTINS, 2013). Apresenta período de crescimento perene. Os frutos apresentam coloração esverdeada para dourado, de 10-15 cm de diâmetro e casca lisa e dura. A polpa dos frutos é macia, esbranquiçada e ligeiramente oleosa, dotados de 1-3 sementes (Figura 4, B e C) (Site: Um pé de que, 2016; MARTINS, 2013). É encontrada principalmente em florestas secas (BALICK et al., 1986). Ocorre ao longo da costa Atlântica, da Bahia a Alagoas (LORENZI et al., 1996).
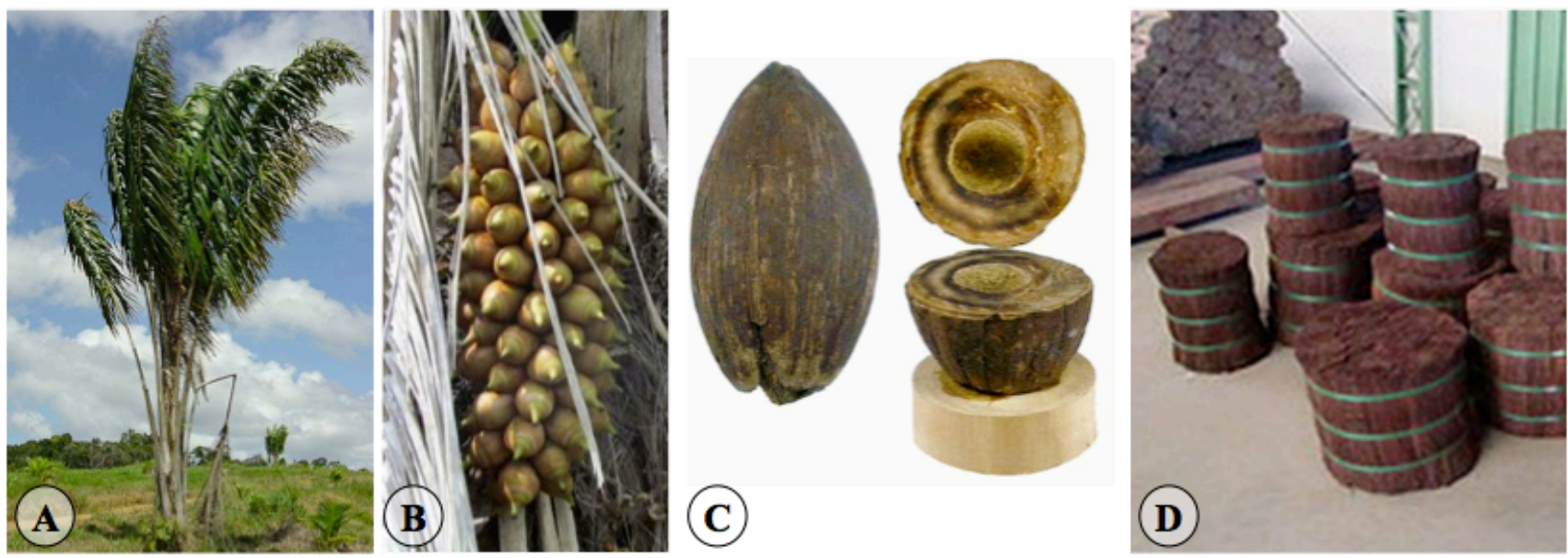

Figura 4. Attalea funifera (Mart.). A. Palmeira (SILVEIRA, 2013). B. Infrutescência (SILVEIRA, 2013). C. Fruto seco seccionado com espaço de uma semente (MARTINS, 2013). D. Piaçava utilizada na fabricação de vassouras (GUIMARÃES et al., 2012).

É uma espécies nativa do Brasil. Ocorre nas regiões nordeste e sudoeste, ao longo da costa Atlântica, da Bahia a Alagoas (LORENZI et al., 1996). 


\section{Attalea maripa (Aubl. Mart.)}

A. maripa é uma palmeira de porte mediano, estipe solitário anelado, medindo de 3 a 20 metros de altura, com tronco de 15 a $25 \mathrm{~cm}$ de diâmetro (Figura 5, A). Suas folhas são rígidas, eretas e arranjadas em espiral no ápice do estipe, de 5 a $8 \mathrm{~m}$ de comprimento, dispostas em cinco direções. O pecíolo das folhas é alongado e possui as margens afiadas e cortantes (LORENZI et al ., 2000). O tamanho médio do fruto é de $5,23 \mathrm{~cm}$ de comprimento e 2,59 $\mathrm{cm}$ de diâmetro; com forma geral ovoide. Apresenta de 1-3 sementes por fruto com variações no formato e tamanho (Figura 5, B e C) (ARAÚJO et al., 2000).
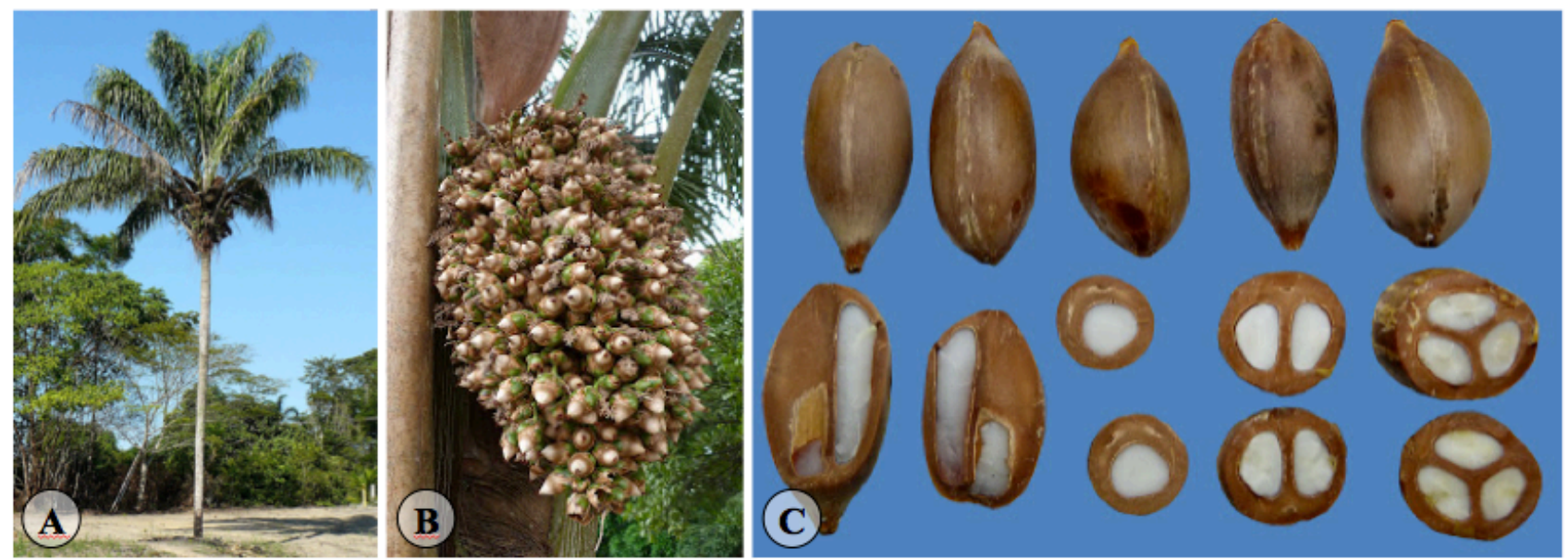

Figura 5. Attalea maripa (Aubl. Mart.). A. Palmeira (Fonte: Afonso Rabelo, 2013). B. Infrutescência MARTINS, 2013). C. Frutos secos inteiros e seccionados, contendo sementes variando de 1 a 3 (Fonte: Afonso Rabelo, 2013).

A. maripa ocorre em Trinidad e Tobago, no norte da Bolívia, Colômbia, Venezuela, Guiana, Suriname, Guiana Francesa, Equador, Peru e Brasil. É encontrada em florestas de várzea, em solos que normalmente não estão inundados (HENDERSON et al., 1995 e LORENZI et al., 1996). 


\section{Attalea phalerata (Mart. ex Spreng.)}

A. phalerata possui o estipe totalmente coberto pelas bainhas foliares (Figura 6, A). A raque da folha pode ser curva no ápice e as pinas apresentam nervuras transversais conspícuas. A inflorescência estaminada apresenta um número maior de ráquilas que a inflorescência andrógina. Estas flores se apresentam em dois tamanhos distintos, as maiores solitárias e as menores enfileiradas, em maior número (CORRÊA et al., 2012). As flores estaminadas frequentemente possuem duas pétalas, que se enrolam no ápice e formam uma abertura lateral; sépalas e pétalas podem apresentar tomento na face externa (MARTINS, 2013). O fruto, presente ao longo de todo ano, apresenta forma elipsoide-oblonga, possuem entre 1 e 4 sementes (Figura 6, B e C).
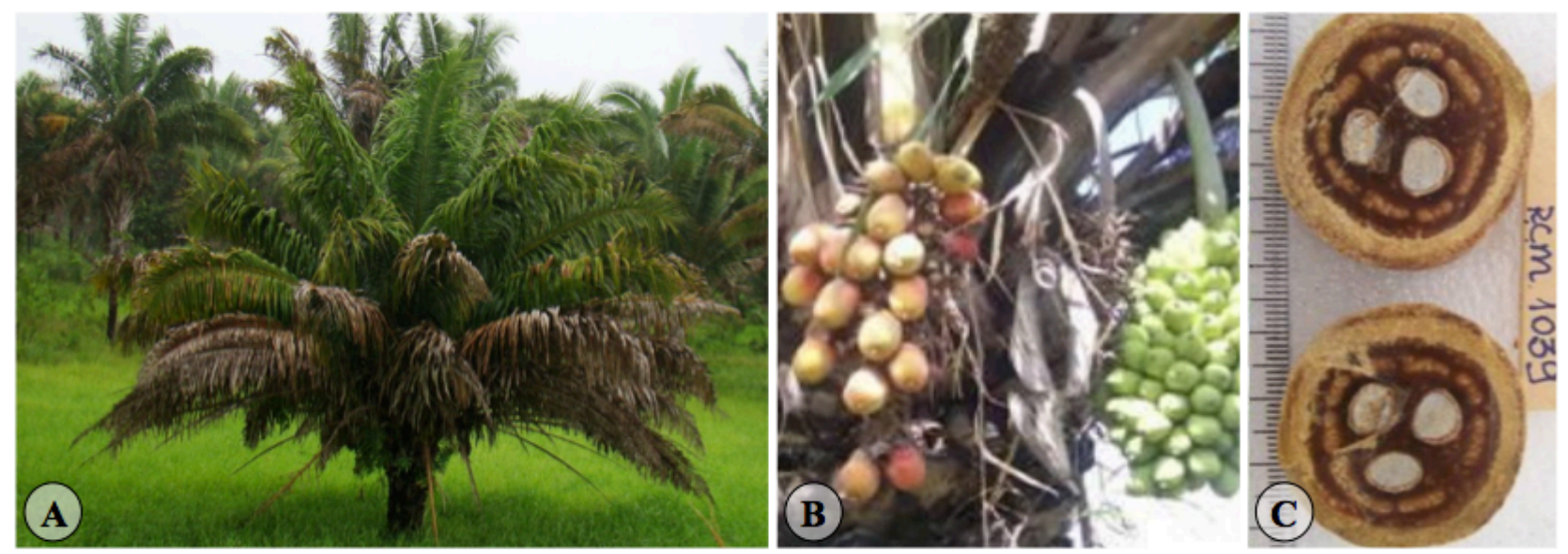

Figura 6. Attalea phalerata (Mart. ex Spreng.). A. Palmeira (Fonte: Marcelo Mattos Cavallari, 2014). B. Infrutescência (MARTINS, 2013). C. Fruto seco seccionado, contendo 3 sementes (MARTINS, 2013).

É nativa do Brasil, Bolívia, Paraguai, Colômbia e Peru, onde cresce no sul e oeste da Amazônia. É a palmeira mais comum no Pantanal (CHOO et al., 2010; CORRÊA et al., 2012). 


\section{Attalea vitrivir (Burret.)}

A. vitrivir apresenta o estipe solitário, colunar, com aparência de taça (Figura 7, A). Apresenta cerca de 10 a $20 \mathrm{~m}$ de altura e estipe com 30 a $50 \mathrm{~cm}$ de diâmetro. Os frutos medem de 10 a $14 \mathrm{~cm}$ de comprimento; com mesocarpo branco, farináceo e seco; endocarpo lenhoso, com feixes de fibras mais ou menos conspícuos e possuem entre 4 e 8 sementes, com endosperma branco e muito oleoso (LORENZI, 2010) (Figura 7, B, C e D).
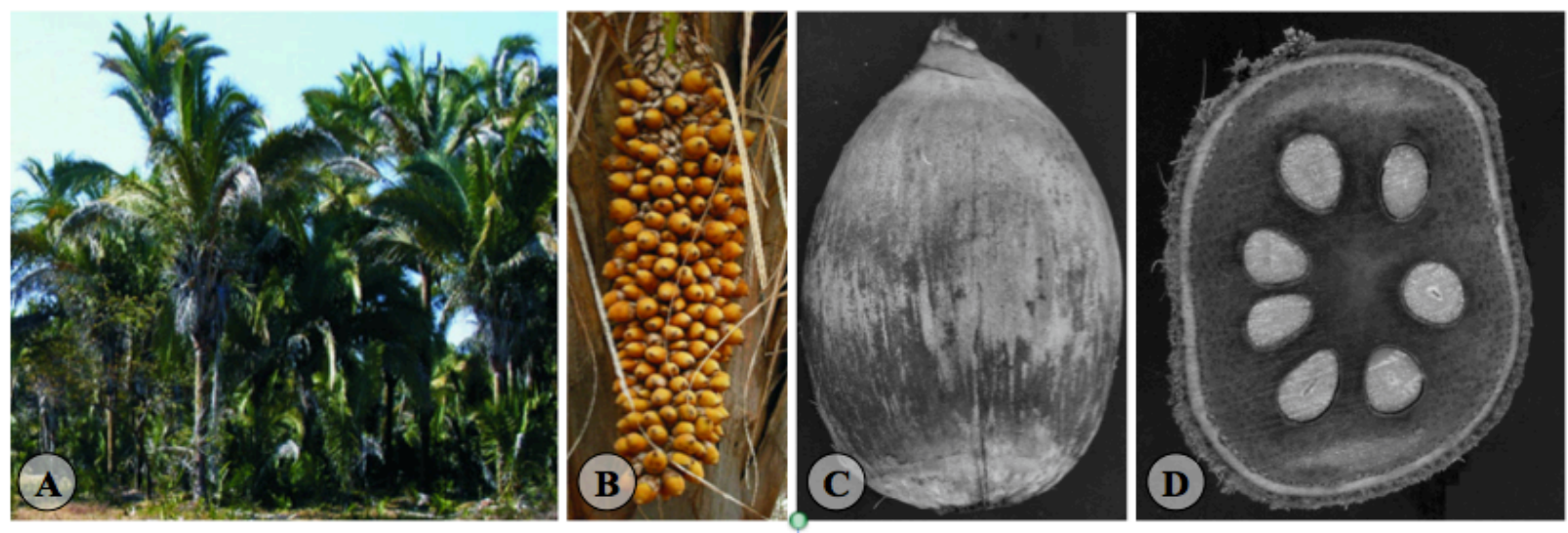

Figura 7. Attalea vitrivir (Burret). A. Palmeira (NEVES, 2013). B. Infrutescência (MARTINS, 2013). C. Fruto seco inteiro (NEVES, 2013). D. Fruto seccionado com 7 sementes (NEVES, 2013).

É encontrada nos estados de Minas Gerais e Bahia, e é nativa da região norte de Minas Gerais e sudoeste da Bahia. Há expressiva ocorrência de populações de $A$. vitrivir em regiões com grande sazonalidade hídrica, no domínio dos Cerrados (LORENZI, 1996).

\section{Híbrido - Attalea x teixeirana (Bondar.)}

A. $x$ teixeirana (Bondar.) representa híbridos entre as espécies A. speciosa e A. eichleri. As características destes híbridos dependem de quanto eles se parecem com as espécies parentais, e podem ser classificadas como: "pindova", "speciosa baixa”, "perinã” e "eichleri grande". Na Figura 8 observa-se um exemplar de cada um dos tipos de híbridos. Na Tabela 2 estão apresentadas as principais características de cada tipo de híbrido. 
Tabela 9. Tipos de híbridos de A. x teixeirana (Bondar.) com suas respectivas características .

\begin{tabular}{ll}
\hline Híbridos & \multicolumn{1}{c}{ Características } \\
\hline "pindova" & Plantas sem estipe, com muitas folhas grandes típicas de $A$. speciosa, eretas, como \\
& grandes, se não fosse a presença de grandes cachos de cocos, denunciando sua \\
& maturidade. \\
"speciosa & Palmeira muito baixa, com aparência de $A$. speciosa, com bainhas persistentes \\
baixa" & desde a base. \\
& São palmeiras altas, de mais de 6 metros. Distinguem-se pelas bainhas \\
"perinã" & persistentes, cachos em alturas relativamente baixas, e curvados na ponta, com \\
folhas menores, e bainhas menores do que em $A$. speciosa. & Nesse padrão, observa-se uma planta com características de $A$. eichleri, porém \\
"eichleri & com grandes dimensões de folhas e partes férteis. \\
\hline
\end{tabular}

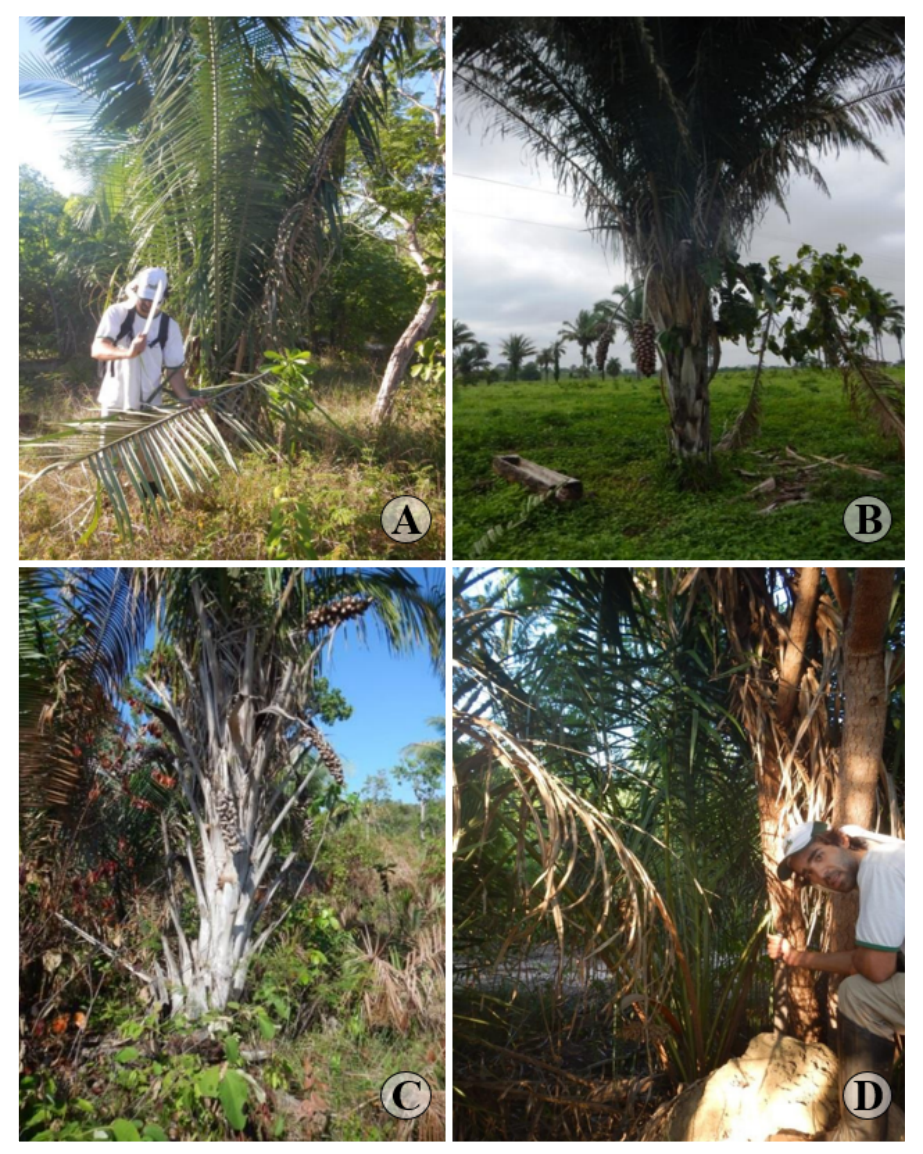

Figura 8 . Attalea x teixeirana (Bondar.). A. "pindova" (Fonte: Marcelo Mattos Cavallari, 2014). B. "speciosa baixa" (Fonte: Marcelo Mattos Cavallari, 2014). C. "perinã" (Fonte: Marcelo Mattos Cavallari, 2014). D. “eichleri grande” (Fonte: Marcelo Mattos Cavallari, 2014). 


\section{Coco do babaçu}

O coco do babaçu produz amêndoas oleaginosas e comestíveis das quais se extrai um óleo, empregado, sobretudo, na alimentação, produção de medicamentos e cosméticos e é objeto de pesquisas avançadas para a fabricação de biocombustíveis (ARAÚJO, 2008). Além disso, estas palmeiras e seus frutos são utilizados na construção de casas, artesanato e paisagismo (LORENZI, 2000; SANTOS et al., 2008).

As amêndoas são extraídas manualmente em um sistema caseiro tradicional e de subsistência e constituem o principal produto de extrativismo de valor mercantil e industrial da espécie (FIGUEIREDO, 2005). Apenas no estado do Maranhão a extração das amêndoas envolve o trabalho de mais de 300 mil famílias (FIGUEIREDO, 2005).

\section{Anatomia vegetal}

Características da morfologia foliar podem ser resultado de fatores ambientais, assim como diferenças típicas de cada espécie. Relações ecológicas, taxonômicas e filogenéticas podem ser elucidadas através da anatomia vegetal (STACE, 1965). Diferenças na anatomia foliar têm se mostrado úteis na definição de grupos, especialmente subfamílias, onde vários caracteres são constantes e diagnósticos (ELLIS et al., 1987; DE OLIVEIRA et al., 2008). Estudos anatômicos auxiliam na classificação das palmeiras ao demosntrar variação nas estruturas internas e externas, determinando características diagnósticas eficazes das espécies (UHL \& DRANSFIELD, 1987).

Adaptações ou modificações anatômicas foliares podem ser decorrentes de níveis variados de luz e estão relacionadas a processos vitais, como fotossíntese e transpiração. Além dos fatores ligados à estrutura anatômica interna das folhas, também é importante o estudo das características morfológicas da superfície foliar, na medida em que elas influenciam variáveis como a quantidade de luz absorvida ou refletida pela folha, a transpiração estomática e cuticular, além de estarem envolvidas nos mecanismos de defesa contra parasitas e patógenos (MARTIN \& JUNIPER, 1970).

Santos e colaboradores (2011) compararam a anatomia foliar de A. barreirensis e $A$. geraensis. Ambas as espécies se encontram no cerrado brasileiro, e sua separação anteriormente era feita somente através de caracteres morfológicos observados em flores estaminadas. Foram observadas diferenças no corte paradérmico: A. barreirensis apresentou-se anfiestomática e $A$. geraensis hipoestomática. Em secção transversal, A. barreirensis apresentou hipoderme descontínua pela presença de esclerênquima na forma de feixes de fibras em ambas as faces epidérmicas, feixes vasculares distribuídos na porção mediana do mesofilo e parênquima aquífero na nervura mediana formado por células globosas, enquanto $A$. geraensis apresentou hipoderme contínua presente apenas 
na epiderme adaxial, feixes vasculares voltados mais à face abaxial e parênquima aquífero na nervura mediana formado por células alongadas.

Alvarado e Jáuregui (2011) estudaram a anatomia da raque e lâmina foliar de A. maripa e A. butyracea, ambas coletadas no mesmo ambiente, "bosque húmedo de Río Claro", estado de Lara, Venezuela. Essas espécies apresentam muitas semelhanças estruturais em seu estágio inicial de desenvolvimento, o que gera dificuldade de reconhecimento no campo. Os autores tinham como objetivos comparar caracteres anatômicos foliares que permitissem a determinação das espécies nestas fases iniciais e a obtenção de informações que elucidassem perguntas taxonômicos relacionados com o grupo. As duas espécies apresentaram várias características comuns, mas distinguem-se pela largura das regiões costais e intercostais na epiderme abaxial, no número de camadas da hipoderme, na presença de ráfides, no número de vasos no metaxilema, entre outras características.

Lopes e colaboradores (2013) estudaram a anatomia foliar de A. microcarpa, relatando acúmulo de esclerênquima, o que caracteriza a planta como escleromórfica, cutícula espessa e incremento de fibras.

O conhecimento das características morfológicas e anatômicas das folhas de palmeiras é importante para o entendimento das suas estruturas, para avaliar interações ou mudanças evolutivas, além de fornecer subsídios para classificação deste grupo de plantas (TOMLINSON, 1990). A identificação correta das espécies é necessária para conservação da variabilidade das espécies e obtenção de informações sobre as características de interesse de cada espécie a ser utilizada em melhoramento. O estudo anatômico das espécies de Attalea propostas neste trabalho visa obter informações que contribuam na classificação taxonômica das espécies deste gênero, auxiliando diretamente os programas de conservação e os programas de melhoramento.

\section{Desenvolvimento e aplicação de DNA barcode}

O sistema de identificação molecular por DNA barcode foi proposto por Hebert e colaboradores (2003) e consiste na utilização de uma pequena sequência de DNA para a discriminação de todas as espécies vivas do planeta como um sistema "bioidentificador" universal (CARVALHO, 2008), equivalente ao “código-de-barras".

A técnica de DNA barcode auxilia na identificação rápida e eficiente das espécies (HEBERT et al., 2003). O principal pressuposto para a efetividade do DNA barcode é que as divergências intraespecíficas sempre sejam menores que as interespecíficas. A monofilia recíproca das espécies 
seria o principal determinante para a existência deste pressuposto (ORTIZ, 2010). O principal objetivo do DNA barcode é estabelecer um recurso que identifique e monitore a biodiversidade, podendo auxiliar na taxonomia.

Em 2004 foi criado o CBOL: Consortium for the Barcode of Life. O loco da Citocromo Oxidase 1 - COI se mostrou bastante eficiente para animais. Em 2007, Kress e Erickson recomendaram as regiões $r b c L$ e $t r n H-p s b A$ como regiões universais de DNA barcode em plantas terrestres. Em 2009, o Plant Working Group - CBOL procurou oferecer um padrão comparando o desempenho de sete regiões de DNA plastidial, sugerindo que duas áreas são recomendadas para plantas: $r b c L$ e matK (CBOL PLANT WORKING GROUP, 2009).

Lahaye e colaboradores (2008) realizaram estudos com amostras de dois hotspots de intensa biodiversidade localizados na Mesoamérica e África do Sul, usando cerca de 1600 amostras, e compararam oito regiões de barcode. Como resultado, identificaram uma porção do gene plastidial matK como um barcode universal para plantas com flores.

Hollingsworth e colaboradores (2011) revisaram o processo de seleção para escolha de barcode em alguns gêneros. Constataram que o sucesso discriminatório das regiões barcode em plantas é claramente menor que em animais, mas a despeito das dificuldades, regiões barcode provaram-se extremamente úteis para numerosas aplicações como ecologia forense, identificação de materiais comercializados, identificações taxonômicas e descobertas de espécies em alguns grupos.

O grupo China Plant Barcode of Life, em 2011, forneceu um conjunto de dados robusto ao abordar esta questão. O Instituto de Botânica de Kunming (China) analisou uma matriz de sequências com 6.286 amostras de 1.757 espécies e 75 famílias de plantas com sementes na China. Utilizaram os barcodes plastidiais $r b c L$, matK e $p s b A-t r n H$, e os espaçadores internos transcritos do DNA ribossômico nuclear (nrDNA ITS). Com este conjunto de dados avaliaram a universalidade dos marcadores, a qualidade das sequências e o poder discriminatório entre as espécies. A maior descoberta a partir deste estudo refere-se ao marcador ITS, que apesar de ter primers que amplificaram consistentemente em menos indivíduos do que os marcadores plastidiais, apresentou um maior poder discriminatório. O marcador ITS também apresenta algumas dificuldades em seu uso, como propensão a amplificar contaminações fúngicas, cópias de genes paralelas e baixa qualidade de sequenciamento. O grupo China Plant BOL concluiu que os benefícios do uso de nrDNA ITS são maiores que suas desvantagens, e que esta abordagem irá melhorar a capacidade de distinção entre espécies de plantas (HOLLINGSWORTH et al., 2011; CHINA PLANT BOL GROUP, 2011). O uso do marcador ITS para identificações em nível de espécie fornece uma base de dados adequada para comparações. Mesmo com suas limitações reconhecidas, é um excelente candidato como um loco eficaz para DNA barcoding em plantas. No entanto, o reconhecimento de 
que ITS tem certas limitações funcionais para o DNA barcode de plantas é um argumento convincente de que é necessária a busca adicional de locos (KRESS et al., 2005). Com esses estudos, fica claro que para grupo de plantas, ao nível de famílias ou gêneros, o marcador ideal ou o conjunto deles ainda deve ser identificado.

Em animais, o gene mitocondrial COI está bem estabelecido como DNA barcode, porém em plantas uma padronização ainda não foi determinada (HEBERT et al., 2003; FORD et al., 2009; KRESS et al., 2009). A associação dos primers de barcode com primers comumente utilizados para trabalhos de filogenia podem produzir avaliações mais robustas (KRESS \& ERICKSON 2007; CBOL - PLANT WORKING GROUP, 2009). O primer PRK (phosphoribulokinase - enzima do ciclo de Calvin) (LEWIS \& DOYLE, 2002; THOMAS, 2006) e o primer RPB2 (polimerase II subunidade B) (RONCAL et al., 2005; THOMAS, 2006) foram utilizados para análises filogenéticas com Arecaceae. Ambas as regiões produzem um número substancial de caracteres informativos, gerando árvores com amplo suporte estatísticos. Eiserhardt e colaboradores (2011) apresentaram uma filogenia de 41 espécies de Bactridinae com 3 marcadores moleculares (PRK, RPB2, ITS) e encontraram boa resolução na separação de cinco gêneros. Norup e colaboradores (2006) examinaram dois gêneros da família Arecaceae, Heterospathe e Rhopaloblaste, usando estes dois genes nucleares. Os autores ratificaram a distinção entre estes dois gêneros. Os resultados apresentaram implicações não só para os dois gêneros em foco, mas também têm sido úteis para a nova classificação da família.

Para que um loco de DNA seja considerado como barcode, é necessário que apresente diferenças significativas entre cada espécie estudada. A variabilidade entre espécies deve ser maior que dentro da espécie (HEBERT et al., 2003). O cenário ideal para a taxonomia molecular é a identificação de uma única região universal, capaz de diferenciar todas ou grande parte das espécies de um reino, a exemplo da COI para animais. Entretanto, em virtude da complexidade das famílias e gêneros de plantas, essa região universal ainda não foi identificada para este grupo. Diante do exposto, propõe-se neste trabalho identificar um loco ou um conjunto de locos capaz de discriminar cada espécie em análise. Este loco ou conjunto de locos deve ser capaz de diferenciar as espécies do gênero Attalea, em virtude do alto polimorfismo entre elas, e ao mesmo tempo apresentar menor ou nenhuma variabilidade intraespecífica. 


\section{Métodos de análises}

\section{UPGMA}

O método UPGMA é baseado em distâncias genéticas (ou similaridades). Este método define a distância entre grupamentos como a distância média entre os pares. É baseado no conceito de que mutações espontâneas se acumulam a uma velocidade constante ao longo do tempo evolutivo em um determinado gene. No método UPGMA, o par de sequências (ou grupo de sequências) a ser agrupado primeiro é aquele que apresenta a menor distância entre todos os pares (ou grupos) de sequências. O ponto de ramificação é definido como a média da distância entre o par de sequências (ou grupo de sequências) (SNEATH \& SOKAL, 1973).

\section{Modelo de Kimura 2-parâmetros (Kimura-2P)}

Transições e transversões são termos usados para se referir a substituições únicas envolvendo nucleotídeos de tipos químicos iguais ou diferentes, com as transições referindo-se às substituições de uma purina por outra purina ou de uma pirimidina por outra pirimidina e as transversões constituindo-se nas substituições envolvendo pirimidinas por purinas ou vice-versa (Tabela 3). O método de distância de Kimura 2P é empregado para avaliar a distância genética entre as sequências, assumindo que a taxa de transições é diferente da taxa de transversões (KIMURA, 1980).

Tabela 10. Tabela de substituições nucleotídicas.

\begin{tabular}{lll}
\hline & Transições & Transversões \\
\hline Substituições & $\mathrm{A} \leftrightarrow \mathrm{G} ; \mathrm{T} \leftrightarrow \mathrm{C}$ & $\mathrm{A} \leftrightarrow \mathrm{T} ; \mathrm{A} \leftrightarrow \mathrm{C} ; \mathrm{G} \leftrightarrow \mathrm{T} ; \mathrm{G} \leftrightarrow \mathrm{C}$ \\
\hline
\end{tabular}

As distâncias de K2P podem ser utilizadas para calcular as distâncias intraespecíficas e interespecíficas de um determinado grupo amostral.

\section{Inferência Bayesiana (IB)}

A IB realiza buscas independentes, que ocasionalmente trocam informações. $\mathrm{O}$ teorema de Bayes permite calcular a probabilidade de um modelo (topologia da árvore e modelo evolutivo) a partir dos resultados que produz, a que se chama probabilidade posterior. Esta análise utiliza 
simulações de cadeias de Markov, nas quais todos os parâmetros do modelo são tratados como variáveis aleatórias, gerando várias árvores com aproximadamente a mesma probabilidade. As árvores de menor probabilidade são eliminadas e a árvore final é um consenso das árvores de maior probabilidade de serem explicadas pelas sequências (RONQUIST \& HUELSENBECK, 2003; LARGET et al., 2005).

\section{Máximo Verossimilhança (MV)}

$\mathrm{Na}$ análise de $\mathrm{MV}$, a árvore gerada é a que maximiza a probabilidade de se chegar à matriz construída com o alinhamento das sequências. O método calcula as probabilidades de acordo com um modelo previamente estabelecido, no qual a expressão matemática, mas não os valores dos parâmetros, são conhecidos a priori, otimizando todos os parâmetros desse modelo até que se obtenha o máximo de probabilidade global. Este modelo é obtido através de programas que analisam a frequência das bases. Os sítios evoluem independentemente - Todos os sítios seguem o mesmo processo de substituição - As probabilidades de substituição não mudam com o tempo (elas podem variar entre os ramos) (FELSENSTEIN, 1981).

\section{Máxima Parcimônia (MP)}

$\mathrm{Na}$ análise de MP, a hipótese apresentada baseia-se na árvore que requer o menor número de passos para ser gerada. Supõe que o caminho evolutivo mais provável é o mais simples, que se explica com o menor número de mudanças (substituições). A premissa básica é que os caracteres em comum (sinapomorfias) são herdados de ancestrais comuns. Os caracteres invariáveis em todos os táxons são ignorados pelo método. Os que apresentam variação em apenas um táxon, apesar de serem diferentes, não são considerados informativos, sendo ignorados pelo método (ALBERT, 2005).

\section{Método bootstrap}

Um dos métodos utilizados para estimar a confiança de uma árvore é o boostrap. Consiste em um teste estatístico para medir o grau de suporte dos nós nas árvores filogenéticas pelo alinhamento das sequências. O valor de bootstrap representa o número de vezes, em porcentagem, que o agrupamento ocorreu nas replicações do método em questão. Um valor de bootstrap para cada nó pode ser chamado de nível de confiança da ocorrência para um determinado clado (agrupamento). 
Este método não avalia a exatidão de uma árvore, somente indica a consistência e estabilidade de clados individualmente (FELSENSTEIN, 1985).

\section{HIPÓTESES}

- Dados morfo-anatômicos foliares podem ser utilizados na diferenciação das sete espécies de babaçu estudadas;

- Existem barcodes de DNA capazes de discriminar as sete espécies de babaçu estudadas.

\section{JUSTIFICATIVA}

O babaçu compreende um complexo de espécies nativas do Brasil de interesse econômico. Está entre os cinco produtos extrativistas que se destacam como produto florestal não madeireiro no Brasil (IBGE 2010). Consiste em uma das melhores fontes alternativas de energia renovável. As amêndoas extraídas de seus frutos são os principais produtos, com valor mercantil e industrial.

Para o desenvolvimento de programas de melhoramento, programas de conservação eficientes (in situ e ex situ) e para um manejo sustentável é necessário conhecer as espécies, suas características ecológicas e a estrutura genética populacional. A classificação das espécies do complexo babaçu é controversa e precisa ser esclarecida. Ferramentas como estudos morfológicos associados a estudos genéticos podem ser utilizadas para auxiliar nesse esclarecimento.

Os marcadores morfológicos são classicamente utilizados para a caracterização e distinção entre as espécies. Estudos anatômicos foliares podem promover uma classificação elucidativa das espécies. Considerando a restrita literatura sobre a anatomia de Attalea, a caracterização estrutural das folhas das espécies estudadas auxiliará no conhecimento anatômico e na indentificação das espécies deste gênero.

Estudos de DNA barcode podem auxiliar na classificação correta das espécies. O DNA barcode fornece um método rápido, preciso e automático para identificação das espécies utilizando regiões do DNA padronizadas (HEBERT et al., 2003). A identificação de regiões barcode auxiliará na correta identificação das espécies estudadas do gênero Attalea.

Neste estudo serão utilizados marcadores moleculares do tipo barcode e serão efetuados estudos morfo-anatômicos foliares de sete espécies de babaçu: A. barreirensis, A. eichleri, A. funifera, A. maripa, A. phalerata, A. speciosa e A. vitrivir. 


\section{OBJETIVO GERAL}

Desenvolver e disponibilizar técnicas moleculares e anatômicas que auxiliem na identificação de sete espécies de babaçu e na caracterização da diversidade genética, de forma a subsidiar a taxonomia do gênero, a conservação da diversidade genética in situ e ex situ e programas de melhoramento.

\section{Objetivos Específicos}

- Analisar e descrever caracteres anatômicos das folhas de sete espécies de babaçu, procurando descrever características capazes de separar táxons e de identificar características estruturais relacionadas ao ambiente em que vivem.

- Identificar marcadores moleculares barcode eficientes na discriminação das sete espécies estudadas.

- Disponibilizar essas metodologias para estudos anatômicos e moleculares que contribuam para ampliar o conhecimento das espécies desse gênero. 


\section{CAPÍTULO 1}

ANATOMIA FOLIAR VEGETAL NO AUXÍLIO À TAXONOMIA DO COMPLEXO BABAÇU (Attalea spp.) 


\section{RESUMO}

O estudo anatômico das espécies de Attalea propostas neste trabalho visa obter informações que ajudem na classificação taxonômica das espécies, o que contribui diretamente para os programas de conservação e programas de melhoramento. Folhas de sete espécies de babaçu foram analisadas: $A$. speciosa, A. barreirensis, A. eichleri, A. funifera, A. maripa, A. phalerata e A. vitrivir. As espécies estudadas apresentaram epiderme unisseriada. Tanto na face adaxial quanto na face abaxial, as células epidérmicas apresentam forma retangular e trapezoide, a espécie $A$. speciosa apresentou ondulações nas paredes das células epidérmicas. Em todas as espécies ambas as faces são revestidas por uma cutícula, sendo que a cutícula da face adaxial é mais espessa que a da face abaxial. Cicatrizes de tricomas tectores glandulares são encontrados tanto na face adaxial quanto na face abaxial de todas as espécies. Foi observado um complexo estomático tetracítico em todas as espécies de Attalea estudadas, sendo classificadas como folhas hipoestomáticas com exceção de $A$. barreirensis, que é anfiestomática. Os estômatos são organizados em fileiras longitudinais paralelas ou perpendiculares às nervuras. As células subsidiárias polares das espécies A. speciosa, A, barreirensis, A. eichleri, A. phalerata e A. vitrivir apresentaram formato reniforme. As das espécies $A$. funifera e $A$. maripa apresentaram formato trapezoide. Todas apresentaram mesofilos dorsiventrais, com 1-3 camadas de parênquima paliçádico e cerca de quatro a oito camadas de parênquima esponjoso. As células do tecido esponjoso são isodiamétricas, ocorrendo esporadicamente células de aspecto retangular. Foram observados corpos silicosos no mesofilo de A. maripa. A nervura central possui um tecido de expansão, multiestratificado, com três a quatro camadas denominados células buliformes. $O$ sistema vascular é formado, exclusivamente, de xilema e floema primários e periciclo. O periciclo, em geral, apresenta-se como fibras. O feixe vascular é rodeado por uma grossa camada de fibras extraxilemáticas. Os feixes colaterais primários encontravam-se travados em pelo menos uma das faces, constatação observada em todas as espécies deste estudo. O número de feixes colaterais entre os feixes secundários variou inclusive dentro da mesma espécie. As nervuras possuem floema indiviso voltado à face abaxial e xilema à adaxial. Para todas as espécies, a hipoderme em geral apresentou-se bem desenvolvida e mais espessa que a epiderme, tanto na face adaxial quanto na abaxial. A. eichleri e A. funifera apresentaram feixes de fibras situados somente na hipoderme adaxial, enquanto que em $A$. speciosa, $A$. barreirensis, $A$. phalerata, $A$. maripa e A. vitrivir os feixes foram encontrados tanto na hipoderme adaxial quanto na hipoderme abaxial. Em todas as sete espécies as fibras estavam situadas internamente à hipoderme. As espécies $A$. barreirensis, $A$. funifera e $A$ vitrivir apresentaram formato trapezoide com extremidade arredondadas. As espécies $A$. speciosa e $A$. eichleri apresentaram formato trapezoide com extremidade agudas. Já as espécies $A$. phalerata e A. maripa apresentaram formato triangular. A margem foliar variou muito entre as espécies. $\mathrm{O}$ formato dos segmentos foliares onde se encontram as nervuras centrais pode ser considerado uma das características mais distintivas entre as espécies estudadas. A anatomia foliar das sete espécies estudadas do gênero Attalea foi muito informativa. Os dados gerados podem auxiliar na identificação das espécies, assim como na classificação taxonômica das mesmas.

Palavras-chave: Attalea, Babaçu, Anatomia foliar 


\section{ABSTRACT}

The anatomical study in this paper was designed to obtain information to assist in the taxonomic classification of Attalea species, which may directly contribute to conservation and breeding programs. Leaves from seven species of babassu were analyzed: A. speciosa, A. barreirensis, A. eichleri, A. funifera, A. maripa, $A$. phalerata and $A$. vitrivir. The species presented a uniseriate epidermis. Both the adaxial and abaxial epidermal cells are rectangular or trapezoidal and $A$. speciosa presented dimples on the walls of the epidermal cells. Both leaf surfaces of all the species are covered by a cuticle, where the adaxial cuticle is thicker than the abaxial. Glandular trichomes scars are are found on both the adaxial epidermis and the abaxial epidermis of all species. The stomatal complex is composed of four cells in all Attalea species studied and are classified as hypostomatic, except for $A$. barreirensis, which is amphistomatic. The stomata are arranged in longitudinal rows, parallel or perpendicular to the ribs. Polar subsidiary cells of $A$. speciosa, $A$, barreirensis, A. eichleri, A. phalerata and A. vitrivir are reniform, but in A. funifera and A. maripa, they are trapezoidal. All species presented dorsiventral mesophyll, with one to three palisade layers and about four to eight layers of spongy parenchyma. The spongy tissue cells are isodiametrical, with soome sporadically occurring rectangular cells. Siliceous bodies were observed in the mesophyll of $A$. maripa. The center rib has a multi-stratified tissue expansion, with three to four layers of bulliform cells. The vascular system is made up exclusively of primary xylem and phloem and pericycle, the latter generally presenting as fibers. The vascular bundle is surrounded by a thick layer of extraxylematic fibers. The first secondary vascular bundles found themselves locked in at least one of the faces, finding seen in all species in this study. The number of side beams between the primary beams varied even within the same species. The ribs have an undivided phloem facing the abaxial side with the xylem facing towards the adaxial surface. For all species, the hypodermis in general is well developed and thicker than the epidermis, both adaxially and abaxially. A. funifera and $A$. eichleri possess fiber bundles located only on the adaxial hypodermis, while in A. speciosa, A. barreirensis, $A$. phalerata, $A$. vitrivir and $A$. maripa, fiber bundles were found in both the adaxial, and abaxial hypodermis. In all seven species, the fibers are located inside the hypodermis. The hypodermal cells of $A$. barreirensis, $A$. funifera and $A$. vitrivir are trapezoidal with a rounded edge, whereas in $A$. speciosa and $A$. eichleri, they are trapezoidal shape with a sharp edge. In A. phalerata and A. maripa the hypodermal cells are triangular shape. The leaf margins varied widely between species. The shape of the leaf segments where they meet the central ribs can be considered one of the most distinctive characteristics of the species studied. The leaf anatomy of the seven Attalea species studied was highly informative. The data generated can assist greatly in identifying these species and provide useful taxonomic characters. However, more leaf anatomical studies are required, associated with genetic and morphological studies to estimate, with greater reliability, the relationships between the species of this genus.

Key words : Attalea, babassu, leaf anatomy 


\section{INTRODUÇÃO}

A família Arecaceae possui cerca de 2.522 espécies, distribuídas entre 240 gêneros, sendo 37 gêneros encontrados no Brasil (DRANSFIELD et al. 2008). Entre estes gêneros, encontra-se o gênero Attalea, composto por cerca de 29 espécies, ainda não totalmente delimitado. Apresenta distribuição que se estende do México à Bolívia, Paraguai, Brasil e Caribe (PINTAUD, 2008). Está presente em muitos tipos de ecossistemas neotropicais, desde dunas de areias até bosques subandinos (PINTAUD, 2008; BAKER \& DRANSFIELD, 2016).

No Brasil, é encontrado nas regiões Norte, Nordeste, Sudeste e Centro-Oeste, abrangendo desde o Sul da Bacia Amazônica até a vegetação típica dos cerrados. Os estados do Maranhão, Piauí e Tocantins concentram as maiores extensões de matas onde predominam os babaçuais (LORENZI et al., 1996; COELHO et al., 2002; ARAÚJO, 2008; MATOS et al., 2010). A delimitação taxonômica do complexo babaçu é discutida por diversos autores. O desenvolvimento de híbridos naturais, o baixo número de coletas e a escassa quantidade de estudos que engloba todos os membros do complexo babaçu dificultam a distinção dessas espécies (ANDERSON \& BALICK, 1988; PINTAUD, 2008).

A importância econômica do babaçu, um dos principais produtos extrativistas do Brasil, é demonstrada pelos dados do IBGE, registrando cerca de 100 mil toneladas de amêndoas são comercializadas no Brasil anualmente (LIMA et al., 2006; IBGE, 2013; DE MESQUITA, 2015). As amêndoas de babaçu fornecem óleo tanto para uso doméstico, como para a utilização industrial em produtos de higiene e perfumaria (LORENZI et al., 1996; LORENZI, 2000; CARAZZA et al., 2001; BRANDÃO et al., 2002). O babaçu também é utilizado na fabricação de artesanatos, na construção civil e no paisagismo, podendo fornecer até 64 produtos diferentes (LORENZI, 2000; SANTOS et al., 2008).

Anatomia foliar tem revelado ser de grande importância taxonômica, especialmente na delimitação de gêneros de Arecaceae (ELLIS et al., 1987; DE OLIVEIRA et al., 2008; MOURA et al., 2015; PINEDO et al., 2016). Estudos anatômicos são significativos para a classificação de palmeiras, visto que estas fornecem características novas características que permitem avaliar as suas inter-relações e mudanças evolutivas (MARTENS \& UHL, 1980; UHL \& DRANSFIELD, 1987; HORN et al., 2009) 
O presente trabalho analisou caracteres anatômicos foliares de sete espécies de babaçu: $A$. speciosa, A. barreirensis, A. eichleri, A. funifera, A. maripa, A. phalerata e A. vitrivir, com o objetivo de verificar o seu valor taxonômico e estimar a distância genética entre as espécies estudadas.

\section{MATERIAL E MÉTODOS}

As amostras foliares de A. barreirensis, A. eichleri, A. funifera, A. maripa, A. phalerata e A. speciosa, foram fornecidas pela Embrapa Cocais, São Luís - MA. Folhas de A. vitrivir foram fornecidas pela Universidade UniMontes, coletadas na região de Montes Claros, MG.

O estudo foi desenvolvido no Laboratório de Anatomia Vegetal da Universidade de Brasília. Foram analisados quatro indivíduos de cada espécie amostrada em campo. Os espécimens examinados estão listados na Tabela 4. O estudo da anatomia foliar foi desenvolvido no Laboratório de Anatomia Vegetal da UnB (Universidade de Brasília). Foram analisados quatro indivíduos de cada espécie amostrada em campo.

Tabela 11. Tabela de amostras utilizadas nas análises de anatomia foliar.

\begin{tabular}{|c|c|c|}
\hline Espécies & Amostras & Localidade \\
\hline A. speciosa & $\begin{array}{l}\text { A. speciosa-S3 } \\
\text { A. speciosa-S4 } \\
\text { A. speciosa - S6 } \\
\text { A. speciosa-S7 }\end{array}$ & $\begin{array}{l}\text { Nazaré, TO. Amostras fornecidas pela Embrapa Cocais, } \\
\text { São Luís - MA. }\end{array}$ \\
\hline A. barreirensis & $\begin{array}{l}\text { A. barreirensis - B13 } \\
\text { A. barreirensis - B15 } \\
\text { A. barreirensis - B16 } \\
\text { A. barreirensis - B17 }\end{array}$ & $\begin{array}{l}\text { São Raimundo das Mangabeiras, MA. Amostras } \\
\text { fornecidas pela Embrapa Cocais, São Luís - MA. }\end{array}$ \\
\hline A. eichleri & $\begin{array}{l}\text { A. eichleri-E14 } \\
\text { A. eichleri-E16 } \\
\text { A. eichleri-E17 } \\
\text { A. eichleri-E19 }\end{array}$ & $\begin{array}{l}\text { Carolina, MA. Amostras fornecidas pela Embrapa } \\
\text { Cocais, São Luís - MA. }\end{array}$ \\
\hline A. funifera & $\begin{array}{l}\text { A. funifera - F2 } \\
\text { A. funifera - F3 } \\
\text { A. funifera - F4 } \\
\text { A. funifera - F6 }\end{array}$ & $\begin{array}{l}\text { Coleção particular do Carlos Alex, BA. Amostras } \\
\text { fornecidas pela Embrapa Cocais, São Luís - MA. }\end{array}$ \\
\hline A. maripa & $\begin{array}{l}\text { A. maripa }-1 \\
\text { A. maripa }-4 \\
\text { A. maripa }-5 \\
\text { A. maripa }-6\end{array}$ & $\begin{array}{l}\text { Coleção particular do Carlos Alex, BA. Amostras } \\
\text { fornecidas pela Embrapa Cocais, São Luís - MA. }\end{array}$ \\
\hline A. phalerata & $\begin{array}{l}\text { A. phalerata }-2 \\
\text { A. phalerata }-3 \\
\text { A. phalerata }-4 \\
\text { A. phalerata }-7\end{array}$ & $\begin{array}{l}\text { Carolina, MA. Amostras fornecidas pela Embrapa } \\
\text { Cocais, São Luís - MA. }\end{array}$ \\
\hline A. vitrivir & $\begin{array}{l}\text { A. vitrivir }-1 \mathrm{M} 1 \\
\text { A. vitrivir }-2 \mathrm{M} 1 \\
\text { A. vitrivir }-3 \mathrm{M} 3 \\
\text { A. vitrivir }-2 \mathrm{BM}\end{array}$ & $\begin{array}{l}\text { Bonito de Minas e Montalvânia - MG - Fornecido pela } \\
\text { Universidade Estadual de Montes Claros. }\end{array}$ \\
\hline
\end{tabular}


Inicialmente, todas as amostras foram incubadas em estufa a $37^{\circ} \mathrm{C}$, numa solução de $\mathrm{KOH}$ $5 \%$ por cinco dias para amolecer as folhas e tornar os cortes possíveis.

Utilizou-se secções do terço apical das pinas. Os cortes transversais foram feitos à mão livre e clarificados com hipoclorito de sódio $(\mathrm{NaClO})$ 100\% [13\% de cloro ativo] por aproximadamente 20 minutos. Em seguida, foram realizadas três lavagens com água destilada por 2-3 minutos. Os cortes foram corados com azul de alcian/safranina (4:1) por 20 segundos, e novamente lavados com água destilada para retirar o excesso de corante. Posteriormente, foram desidratados com a seguinte série alcoólica: álcool 50\% por um minuto, álcool comercial por um minuto, seguido de álcool comercial por três minutos e por fim, álcool absoluto por cinco minutos. Finalmente, os cortes passaram pela segunda bateria que consistiu em lavagens de poucos segundos com as seguintes soluções: álcool 100\%/acetato de butila (3:1), depois álcool 100\%/ acetato de butila (1:1), seguido de álcool 100\%/ acetato de butila (1:3), e por fim acetato puro. As lâminas permanentes foram montadas com verniz vitral.

As faces abaxial e adaxial das folhas foram tratadas para a obtenção de cortes paradérmicos. As amostras foliares com cerca de $1 \mathrm{~cm}^{2}$ foram colocadas em vidros fechados contendo solução de Franklin 30\% (JOHANSEN, 1940). Os vidros contendo as amostras foram incubados em estufa a 60 ${ }^{\circ} \mathrm{C}$ por sete dias até a completa dissociação da epiderme. Após o descarte da solução de Franklin, as amostras foram lavadas em água destilada por cinco vezes para retirar o excesso da solução. O isolamento dos cortes paradérmicos foi feito com o auxílio de pincéis. As amostras foram coradas com safranina por um minuto e posteriormente lavadas três vezes para a retirada do excesso de corante. Em seguida, foram colocadas na lâmina, sendo cobertas com gelatina e lamínula, selada com esmalte incolor.

O registro das imagens foi realizado em fotomicroscópio associado ao microcomputador com sistema de captura de imagens LAS EZ. As lâminas foram fotografadas em microscópio óptico Motic BA300 com câmera digital acoplada. Foram avaliadas as seguintes características: espessura do limbo, espessura das epidermes adaxial e abaxial, espessura das hipodermes adaxial e abaxial das folhas. As espessuras médias foram calculadas pela avaliação de cinco medições.

Os dados morfológicos das pinas observados nas sete espécies foram organizados em uma tabela (Anexo I- páginas 90-92) na qual para cada característica morfológica foi determinado um valor numérico: 1 para presença ou 0 para ausência. Os dados obtidos foram analisados utilizando-se o programa NTSYS-pc (Numerical Taxonomy and Multivariate Analysis System), versão 2.02.. A similaridade entre as amostras foi estimada pelo coeficiente de Jaccard. A confiabilidade dos nós foi calculada pelo programa BOOD (COELHO, 2000). A matriz de similaridade foi então gerada, e 
também o dendograma pelo método UPGMA (Unweighted Pair-Group Method Using Arithmetic Average) .

\section{RESULTADOS}

\section{Descrição anatômica}

Attalea speciosa

Feixe vascular principal colateral, ovoide, livre, tanto adaxial quanto abaxialmente, envolto em feixe de fibras extraxilemáticas, região da nervura principal com formato trapezoide, com ângulos arredondados; protoxilema voltado para a face adaxial; floema permeando o xilema abaxialmente e adaxialmente (Fig. 9-A); células buliformes retangulares, em grupos 3-4 vezes mais largo que alto, 3 camadas celulares (Fig. 9-A); grupos de fibras permeando as células buliformes (Fig. 9-A); mesofilo dorsiventral (141 $\mu \mathrm{m}$ de espessura) (Fig. 9-B); parênquima paliçádico com uma camadas de células, mais de 5 vezes mais altas do que largas (Fig. 9-B); parênquima lacunoso com células isodiamétricas (3-4 camadas celulares) (Fig. 9-B); hipoderme adaxial espessa (57,8 $\mu \mathrm{m}$ de espessura), células isodiamétricas ou ovoides (Fig. 9-B); hipoderme abaxial espessa (21 $\mu \mathrm{m}$ de espessura); grupos de fibras localizadas entre a epiderme e a hipoderme adaxial, e entre a epiderme e a hipoderme abaxial (Fig. 9-B); lâmina foliar plana adaxialmente e abaxialmente (Fig. 9C); feixes vasculares de primeira ordem travados tanto adaxialmente quanto abaxialmente (Fig. 9C); feixes vasculares de segunda ordem travados abaxialmente (Fig. 9-C); feixes vasculares de terceira ordem travados abaxialmente (Fig. 9-C); cicatriz de tricomas glandulares presentes em ambas as faces (Fig. 9-C); margem foliar com ângulo agudo ou obtuso, permeada por feixes vasculares e ondulações na face abaxial (Fig. 9-D); epiderme uniestratificada (Figs. 9-E e 9-F); cutícula adaxial delgada $3,2 \mu \mathrm{m}$ (Fig. 9-E); células comuns da epiderme da face adaxial retangulares ou trapezóides $(33,5 \mu \mathrm{m}-64,5 \mu \mathrm{m}$ de comprimento por 10,5 $\mu \mathrm{m}$ de largura) (Fig. 9-E) e paredes das células epidérmicas com ondulações (Fig. 9-G); cutícula abaxial delgada (1 $\mu \mathrm{m})$ (Fig. 9-F); células comuns da epiderme da face abaxial retangulares ou trapezoides ( $27 \mu \mathrm{m}-63,5 \mu \mathrm{m}$ de comprimento por 11,67 $\mu \mathrm{m}$ de largura) (Fig. 9-H); complexo estomático tetracítico, estômatos dispostos regularmente em fileiras (Fig. 9-H); câmaras subestomáticas presentes (Fig. 9-F); células-guarda 2-3 vezes mais compridas que largas $(22,7 \mu \mathrm{m}$ de comprimento e $7 \mu \mathrm{m}$ de largura) com formato reniforme (Fig. 9-H); células subsidiárias laterais com formato reniformes (Fig. 9-H); células subsidiárias polares com formato reniformes (Fig. 9- H). 

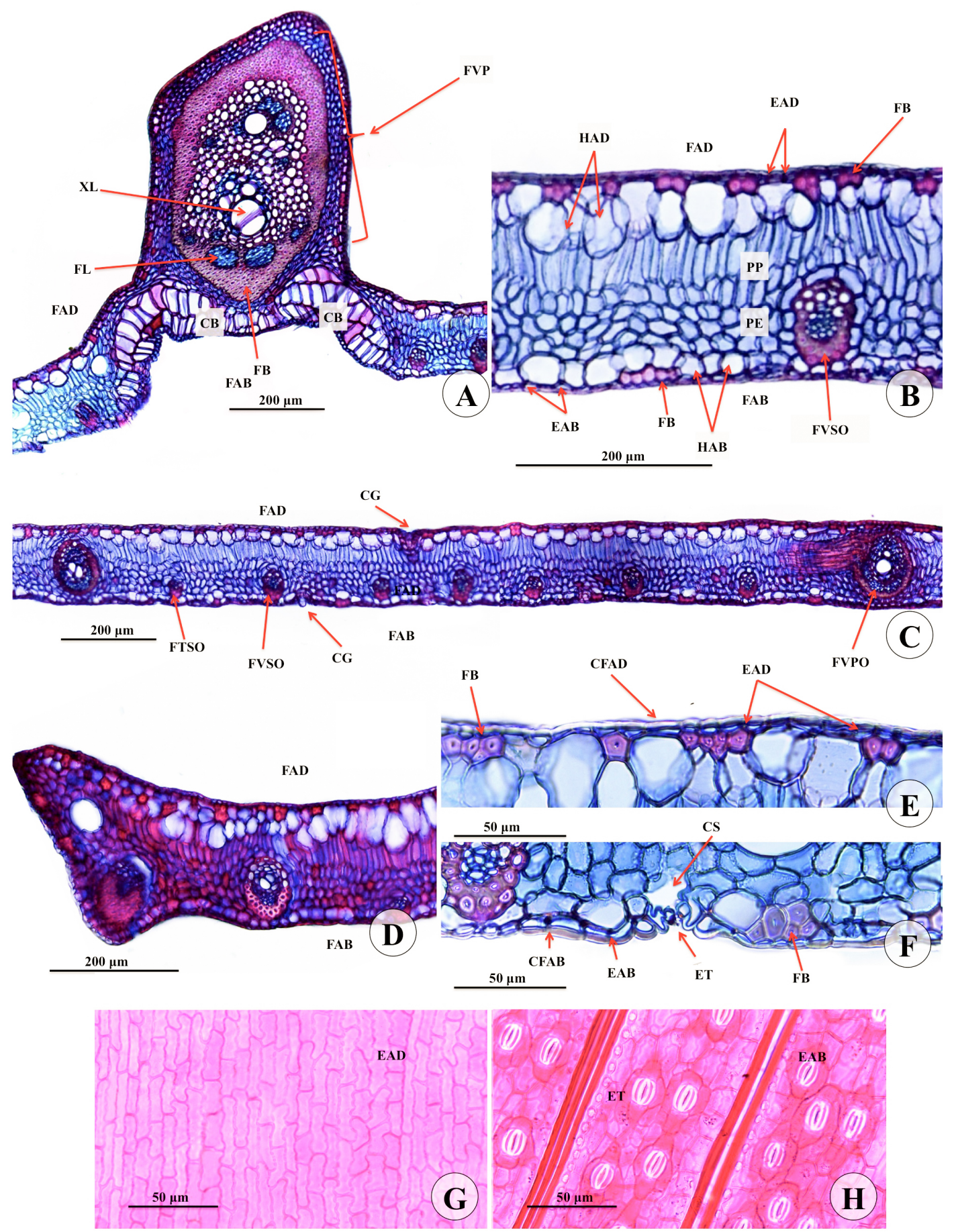

Figura 9. Anatomia foliar de Attalea speciosa (Mart. ex Spreng.). A-F: Secções transversais; G-H: Cortes paradérmicos. A. Segmento foliar com a nervura principal com formato trapezoide e ângulos arredondados: FVP- Feixe vascular principal, XL - Xilema, FL-Floema, FB - Fibras, CB - células buliformes, FAD - Face adaxial, FAB - Face abaxial. B. Ampliação da lâmina foliar: FAD - Face adaxial, FAB - Face abaxial, HAD Hipoderme da face adaxial, HAB - Hipoderme da face abaxial, FB - Fibras, EAD - Epiderme da face adaxial, EAB - Epiderme da face abaxial, PP- Parênquima Paliçádico, PE-Esponjoso, FVSO -Feixe vascular de segunda ordem. C. Padrão dos feixes vasculares na lâmina foliar: FAD - Face adaxial, FAB - Face abaxial, FVPO-Feixe vascular de primeira ordem, FVSO-Feixe vascular de segunda ordem, CG-Cicatriz glandular. D. Margem foliar com ângulos obtusos. E. Ampliação da face adaxial: CFAD - Cutícula da face adaxial, EAD- epiderme da face adaxial, FB - Fibras F. Ampliação da face abaxial: CFAB - Cutícula da face abaxial, EAB- epiderme da face adaxial, CS- Câmara subestomática, ET: Estômato G. Epiderme da face adaxial, parades com ondulações. H. Epiderme da face abaxial com disposição dos estômatos, ET: Estômato. Escalas: A- D: 200 um. E-H: 50 um. 
Feixe vascular principal colateral, ovoide, livre, tanto adaxial quanto abaxialmente, envolto em de feixe de fibras extraxilemáticas, região da nervura principal com formato trapezoide, com ângulo agudo (Fig. 10-A); protoxilema voltado para a face adaxial; floema permeando o xilema abaxialmente e adaxialmente (Fig. 10-A); células buliformes retangulares, em grupos 3-4 vezes mais largo que alto, 3 camadas celulares (Fig. 10-A); grupos de fibras permeando as células buliformes (Fig. 10-A); mesofilo dorsiventral (280 $\mu \mathrm{m}$ de espessura), 6-9 camadas de células (Fig. 10-B); parênquima paliçádico com 2-3 camadas de células, mais de 5 vezes mais altas do que largas (Fig. 10-B); parênquima lacunoso com células isodiamétricas (Fig 10-B); hipoderme adaxial espessa $(48,2 \mu \mathrm{m})$ com células isodiamétricas ou ovoides (Fig. 10-B); hipoderme abaxial espessa $(30,5 \mu \mathrm{m})$ com células isodiamétricas ou ovoides (Fig. 10-B); grupos de fibras localizadas entre a epiderme e a hipoderme adaxial, e entre a epiderme e a hipoderme abaxial (Fig. 10-B); lâmina foliar com ondulações adaxialmente e abaxialmente (Fig. 10-C); feixes vasculares de primeira ordem livres adaxialmente e travados abaxialmente (Fig. 10-C); feixes vasculares de segunda ordem livres (Fig. 10-C); feixes vasculares de terceira ordem travados abaxialmente (Fig. 10-C); cicatriz de tricomas glandulares presentes em ambas as faces (Fig. 10-C); margem foliar com ângulo agudo ou obtuso, permeada por feixes vasculares e ondulações na face abaxial (Fig. 10D); epiderme uniestratificada (Figs. 10-E e 10-F); cutícula espessa adaxialmente (10,7 $\mu \mathrm{m})$ (Fig. 10-E); células comuns da epiderme da face adaxial retangulares $(56,7 \mu \mathrm{m}-85 \mu \mathrm{m}$ de comprimento por 10,8 $\mu \mathrm{m}$ de largura) (Fig. 10-G); cutícula espessa abaxialmente $(6,8 \mu \mathrm{m})$ (Fig. 10-F); células comuns da epiderme da face abaxial retangulares, com paredes lisas $(30,2 \mu \mathrm{m}-63 \mu \mathrm{m}$ de comprimento por 11,2 $\mu \mathrm{m}$ de largura) (Fig. 10-H); câmaras subestomáticas presentes (Figs. 10-E e 10-F); complexo estomático tetracítico, estômatos dispostos regularmente em fileiras (Figs. 10-G e 10-H); células-guarda mais compridas que largas $(20,4 \mu \mathrm{m}$ de comprimento e $6,8 \mu \mathrm{m}$ de largura) com formato reniforme (Figs. 10-G e 10-H); células subsidiárias laterais com formato reniformes (Figs. 10-G e 10-H); células subsidiárias polares com formato reniformes (Figs. 10-G e 10-H); pinas anfiestomáticas (Figs. 10-G e 10-H). 

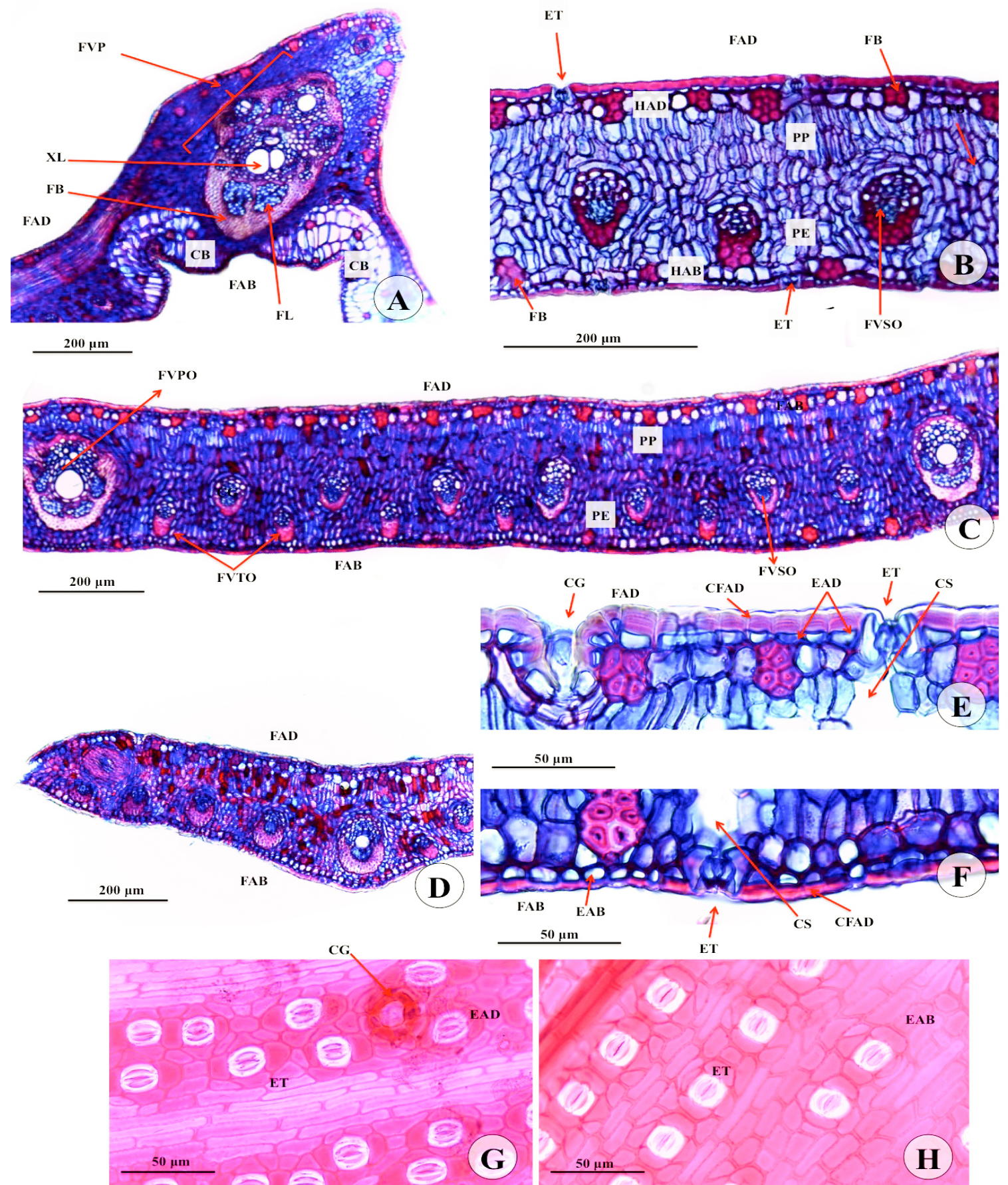

Figura 10. Anatomia foliar de Attalea barreirensis (Glassman.). A-F: Secções transversais; G-H: Cortes paradérmicos. A. Segmento foliar com a nervura principal com formato trapezoide e ângulo agudo: FVP- Feixe vascular principal, XL - Xilema, FL-Floema, FB - Fibras, CB - células buliformes, FAD - Face adaxial, FAB Face abaxial. B. Ampliação da lâmina foliar: FAD - Face adaxial, FAB - Face abaxial, HAD - Hipoderme da face adaxial, HAB - Hipoderme da face abaxial, FB - Fibras, EAD - Epiderme da face adaxial, EAB - Epiderme da face abaxial, PP- Parênquima Paliçádico, PE-Esponjoso, FVSO -Feixe vascular de segunda ordem. C. Padrão dos feixes vasculares na lâmina foliar: FAD - Face adaxial, FAB - Face abaxial, FVPO-Feixe vascular de primeira ordem, FVSO - Feixe vascular de segunda ordem. D. Margem foliar com ângulo obtuso. E. Ampliação da face adaxial: CFAD - Cutícula da face adaxial, EAD- epiderme da face adaxial, FB - Fibras, CG- Cicatriz glandular. F. Ampliação da face abaxial: CFAB - Cutícula da face abaxial, EAB- epiderme da face adaxial, ET: Estômatos, CS- Câmara subestomática G. Epiderme da face adaxial, estômatos dispostos em fileiras. ET: Estômatos. H. Epiderme da face abaxial com disposição dos estômatos em fileiras. ET: Estômatos. Escalas: A- D: $200 \mu \mathrm{m}$. E-H: $50 \mu \mathrm{m}$. 
Feixe vascular principal colateral, ovoide, livre, tanto adaxial quanto abaxialmente, envolto em de feixe de fibras extraxilemáticas (Fig.11-A); região da nervura principal com formato trapezoide de ângulos agudos, protoxilema voltado para a face adaxial; floema permeando o xilema abaxialmente e adaxialmente (Fig.11-A); células buliformes retangulares, em grupos 2-3 vezes mais largo que alto, 3 camadas celulares (Fig.11-B); grupos de fibras permeando as células buliformes (Fig. 11-A); mesofilo dorsiventral (170,75 $\mu \mathrm{m})$, 5-7 camadas de células (Fig. 11-B); parênquima paliçádico com 2-3 camadas de células, mais de 4 vezes mais altas do que largas (Fig. 11-B); parênquima lacunoso com células isodiamétricas (Fig. 11-B); hipoderme adaxial espessa (28,25 $\mu \mathrm{m}$ de espessura), células isodiamétricas ou ovoides (Fig. 11-B); grupos de fibras localizadas entre a epiderme e a hipoderme adaxial (Fig. 11-B); hipoderme abaxial delgada (10,92 $\mu \mathrm{m}$ de espessura), células isodiamétricas ou ovoides (Fig. 11-B); lâmina foliar plana abaxialmente e com ondulações abaxialmente (Fig. 11-C); feixes vasculares de primeira ordem travados adaxialmente e livres abaxialmente (Fig. 11-C); feixes vasculares de segunda ordem travados abaxialmente (Fig. 11-C); cicatriz de tricomas glandulares presentes em ambas as faces (Fig. 11-C); margem foliar com ângulo agudo ou obtuso, permeada por feixes vasculares travados abaxialmente (Fig. 11-D); epiderme uniestratificada (Figs. 11-E e 11-F); cutícula espessa adaxialmente $(7,67 \mu \mathrm{m})($ Fig. 11E); células comuns da epiderme da face adaxial retangulares com paredes lisas $(29,5 \mu \mathrm{m}-30,7 \mu \mathrm{m}$ de comprimento por 11,92 $\mu \mathrm{m}$ de largura) (Fig. 11-G); cutícula espessa abaxialmente $(9,05 \mu \mathrm{m})$ (Fig. 11-F); células comuns da epiderme da face abaxial retangulares $(25,5 \mu \mathrm{m}-40,75 \mu \mathrm{m}$ de comprimento por 10,6 $\mu \mathrm{m}$ de largura) (Fig. 11-H); câmaras subestomáticas ausentes (Fig. 11-F); complexo estomático tetracítico, estômatos dispostos regularmente em fileiras (Fig. 11-H); célulasguarda mais compridas que largas $(21,7 \mu \mathrm{m}$ de comprimento e 5,75 $\mu \mathrm{m}$ de largura) com formato reniforme (Fig. 11-H); células subsidiárias polares com formato reniformes (Fig. 11-H); células subsidiárias laterais com formato reniformes (Fig. 11-H); pinas hipoestomáticas (Figs. 11-G e 11$\mathrm{H})$. 


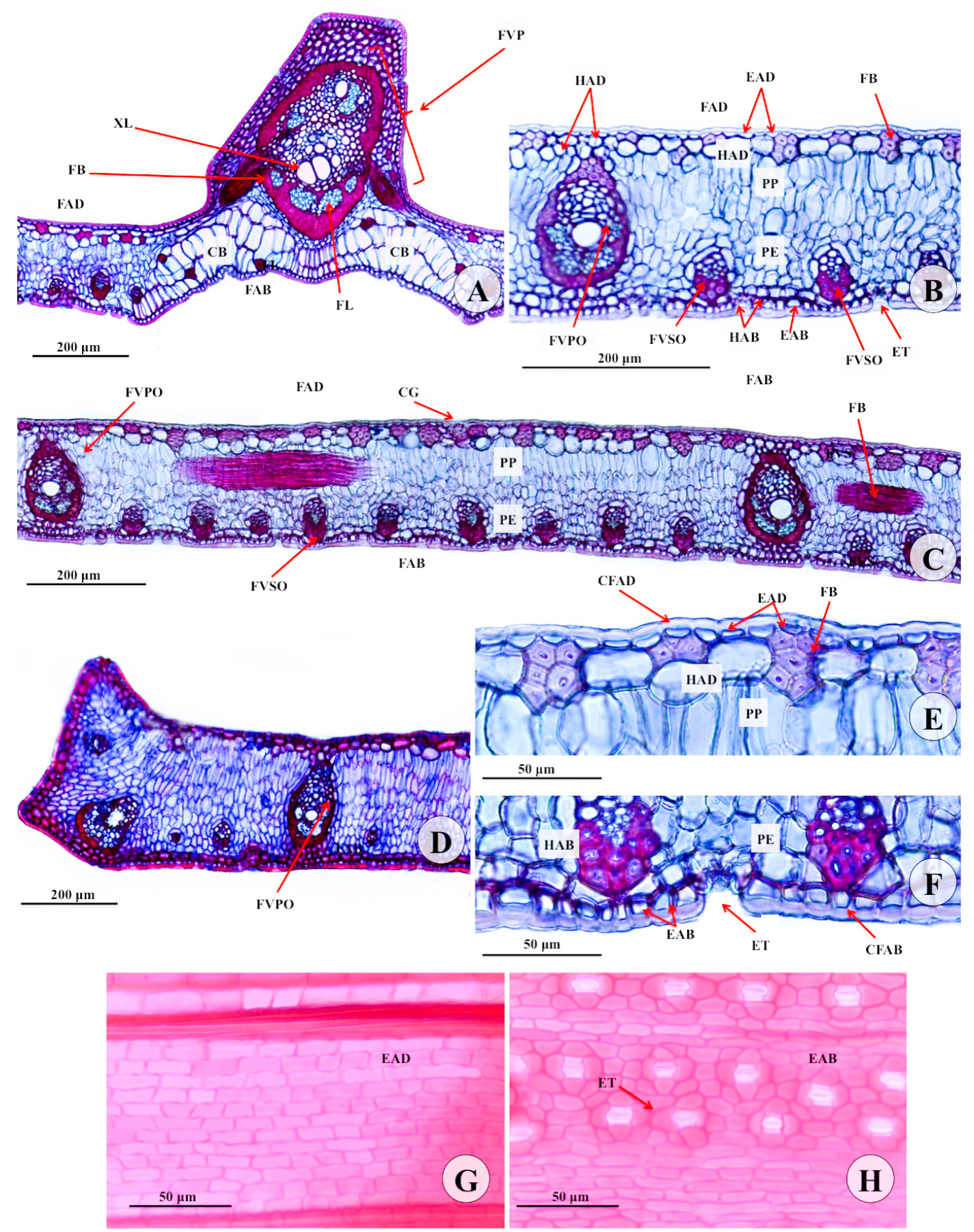

Figura 11. Anatomia foliar de Attalea eichleri (Drude A. J. Hend.). A-F: Secções transversais; G-H: Cortes paradérmicos. A. Segmento foliar com a nervura principal com formato trapezoide e ângulo agudo: FVP- Feixe vascular principal, XL - Xilema, FL-Floema, FB - Fibras, CB - células buliformes, FAD - Face adaxial, FAB Face abaxial. B. Ampliação da lâmina foliar: FAD - Face adaxial, FAB - Face abaxial, HAD - Hipoderme da face adaxial, HAB - Hipoderme da face abaxial, FB - Fibras, EAD - Epiderme da face adaxial, EAB - Epiderme da face abaxial, PP- Parênquima Paliçádico, PE-Esponjoso, FVPO- Feixe vascular de primeira ordem, FVSO Feixe vascular de segunda ordem. C. Padrão dos feixes vasculares na lâmina foliar: FAD - Face adaxial, FAB Face abaxial, FVPO-Feixe vascular de primeira ordem, FVSO - Feixe vascular de segunda ordem. D. Margem foliar com ângulo obtuso. E. Ampliação da face adaxial: CFAD - Cutícula da face adaxial, EAD- epiderme da face adaxial, FB - Fibras. F. Ampliação da face abaxial: CFAB - Cutícula da face abaxial, EAB- epiderme da face adaxial, ET: Estômatos. G. Epiderme da face adaxial. H. Epiderme da face abaxial com disposição dos estômatos em fileiras. ET: Estômatos. Escalas: A- D: $200 \mu \mathrm{m}$. E-H: $50 \mu \mathrm{m}$. 
Attalea funifera

Feixe vascular principal colateral, ovoide, livre, tanto adaxial quanto abaxialmente, envolto em de feixe de fibras extraxilemáticas (Fig. 12-A); região da nervura principal com formato triangular de ângulos agudos, protoxilema voltado para a face adaxial; floema permeando o xilema abaxialmente e adaxialmente (Fig. 12-A); células buliformes retangulares, em grupos 2-3 vezes mais largo que alto, 3 camadas celulares (Fig. 12-B); grupos de fibras permeando as células buliformes (Fig. 12-A); mesofilo dorsiventral (136 $\mu \mathrm{m}), 5-7$ camadas de células (Fig. 12-B); parênquima paliçádico com uma camadas de células, mais de 3 vezes mais altas do que largas (Fig. 12-B); parênquima lacunoso com células isodiamétricas (Fig. 12-B); hipoderme adaxial espessa (37,8 $\mu \mathrm{m}$ de espessura), células isodiamétricas ou ovoides (Fig. 12-B); hipoderme abaxial espessa (32 $\mu \mathrm{m}$ de espessura), células isodiamétricas ou ovoides (Fig. 12-B); grupos de fibras localizadas entre a epiderme e a hipoderme adaxial (Fig. 12-B); lâmina foliar com ondulações adaxialmente e plana abaxialmente (Fig. 12-B); feixes vasculares de primeira ordem travados adaxialmente e abaxialmente (Fig. 12-C); feixes vasculares de segunda ordem travados abaxialmente (Fig. 12-C); cicatriz de tricomas glandulares presentes em ambas as faces (Fig. 12-C); margem foliar com ângulo agudo ou obtuso, permeada por feixes vasculares travados abaxialmente (Fig. 12-D); epiderme uniestratificada (Figs. 12-E e 12-F); cutícula delgada adaxialmente $(8,77 \mu \mathrm{m})($ Fig. $12-$ E); células comuns da epiderme da face adaxial com formato retangular ou trapezoide $(30,75 \mu \mathrm{m}-$ $48,0 \mu \mathrm{m}$ de comprimento por $11,65 \mu \mathrm{m}$ de largura) (Fig. 12-H); cutícula delgada abaxialmente $(4,56$ $\mu \mathrm{m})$ (Fig. 12-F); células comuns da epiderme da face abaxial retangulares ou trapezoides $(39,5 \mu \mathrm{m}$ - 62,75 $\mu \mathrm{m}$ por 9,92 $\mu \mathrm{m}$ ) (Fig. 12-F); câmaras subestomáticas ausentes (Fig. 12-F); complexo estomático tetracítico, estômatos dispostos regularmente em fileiras (Fig. 12-H); células-guarda mais compridas que largas $(22,2 \mu \mathrm{m}$ de comprimento e 8,55 $\mu \mathrm{m}$ de largura) com formato reniforme (Fig. 12-G); células subsidiárias polares com formato trapezoide (Fig. 12-H); células subsidiárias laterais com formato reniforme (Fig. 12-H); pinas hipoestomáticas (Figs. 12-G e 12-H). 

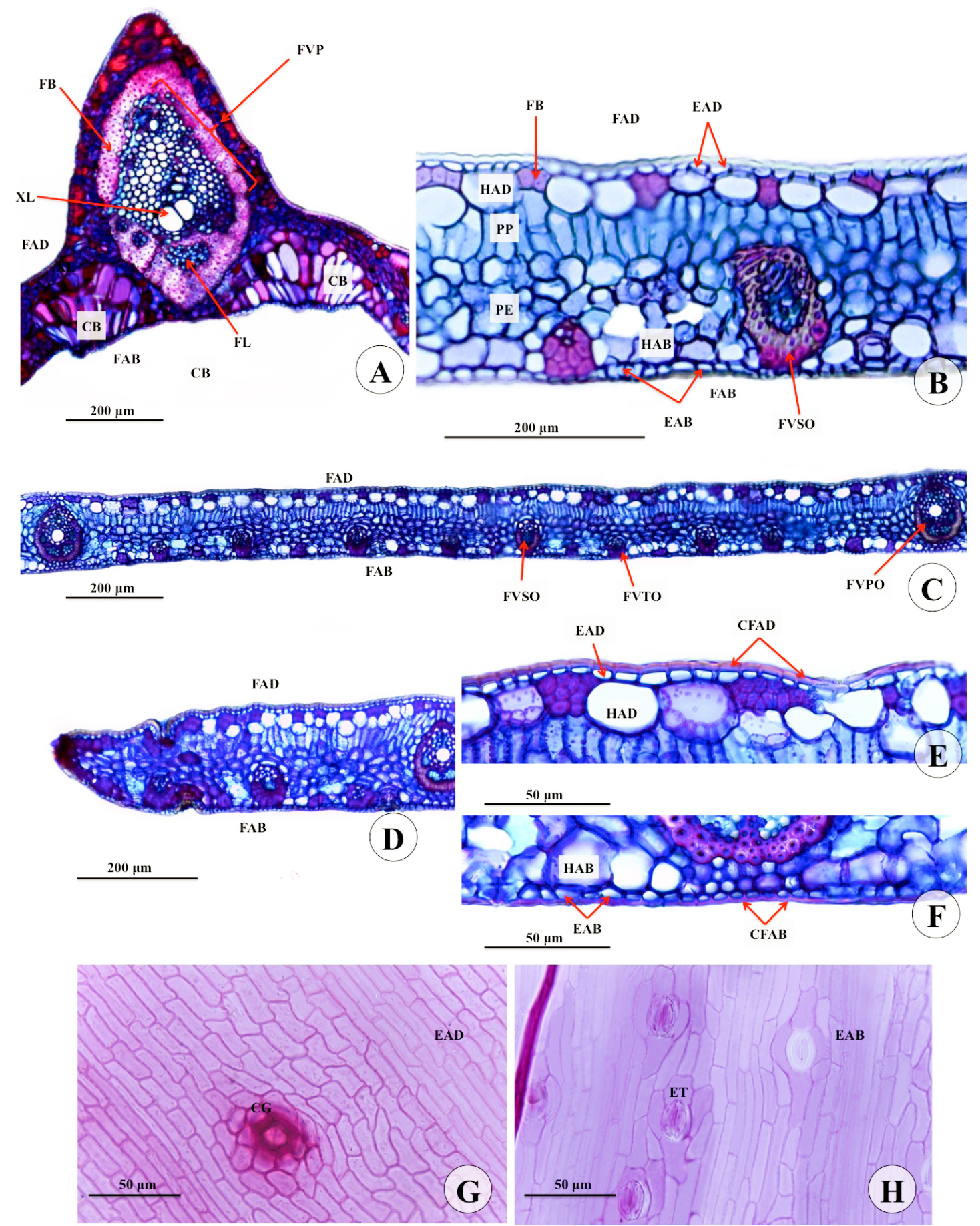

Figura 12. Anatomia foliar de Attalea funifera (Mart.). A-F: Secções transversais; G-H: Cortes paradérmicos. A. Segmento foliar com a nervura principal com formato triangular e ângulo agudo: FVP- Feixe vascular principal, XL - Xilema, FL-Floema, FB - Fibras, CB - células buliformes, FAD - Face adaxial, FAB - Face abaxial. B. Ampliação da lâmina foliar: FAD - Face adaxial, FAB - Face abaxial, HAD - Hipoderme da face adaxial, HAB Hipoderme da face abaxial, FB - Fibras, EAD - Epiderme da face adaxial, EAB - Epiderme da face abaxial, PPParênquima Paliçádico, PE-Esponjoso, FVSO -Feixe vascular de segunda ordem. C. Padrão dos feixes vasculares na lâmina foliar: FAD - Face adaxial, FAB - Face abaxial, FVPO-Feixe vascular de primeira ordem, FVSO Feixe vascular de segunda ordem, FVTO - Feixe vascular de terceira ordem D. Margem foliar com ângulo obtuso. E. Ampliação da face adaxial: CFAD - Cutícula da face adaxial, EAD- epiderme da face adaxial. F. Ampliação da face abaxial: $C F A B$ - Cutícula da face abaxial, EAB- epiderme da face adaxial. G. Epiderme da face adaxial, CG- Catriz glandular. H. Epiderme da face abaxial com disposição dos estômatos em fileiras. ET: Estômatos. Escalas: A- D: $200 \mu \mathrm{m}$. E-H: $50 \mu \mathrm{m}$. 
Feixe vascular principal colateral, ovoide, livre, tanto adaxial quanto abaxialmente, envolto em de feixe de fibras extraxilemáticas, região da nervura principal com formato triangular, com angulo agudo (Fig. 13-A); protoxilema voltado para a face adaxial; floema permeando o xilema abaxialmente e adaxialmente (Fig. 13-A); células buliformes retangulares, em grupos 2-3 vezes mais largo que alto, 3 camadas celulares (Fig. 13-B); grupos de fibras permeando as células buliformes (Fig. 13-A); mesofilo dorsiventral (115,75 $\mu \mathrm{m})$, 5-7 camadas de células (Fig. 13-B); parênquima paliçádico com 1 camadas de células, mais de 4 vezes mais altas do que largas (Fig. 13-B); parênquima lacunoso com células isodiamétricas; entre a camada de células paliçádicas e o parênquima esponjoso foi observada a presença de corpos silicosos em vários cortes (destaque da figura 13-B); hipoderme adaxial espessa (25,2 $\mu \mathrm{m}$ de espessura), células isodiamétricas ou ovoides (Fig. 13-B); grupos de fibras localizadas entre a epiderme e a hipoderme adaxial (Fig. 13-B); hipoderme abaxial delgada (8,5 $\mu \mathrm{m}$ de espessura), células retangulares ou ovoides (Fig. 13-B); grupos de fibras localizadas entre a epiderme e a hipoderme abaxial (Fig. 13-B); lâmina foliar com ondulações adaxialmente e abaxialmente (Fig. 13-C); feixes vasculares de primeira ordem livres abaxialmente e travados adaxialmente (Fig. 13-C); feixes vasculares de segunda ordem travados abaxialmente (Fig. 13-C); cicatriz de tricomas glandulares presentes em ambas as faces (Fig. 13C); margem foliar arredondada, permeada por feixes vasculares livres (Fig. 13-D); epiderme uniestratificada (Figs. 13-E e 13-F); cutícula espessa adaxialmente (5,37 $\mu \mathrm{m})$ (Fig. 13-E); células comuns da epiderme da face adaxial retangulares, trapezoides ou em formato de losango $(26,5 \mu \mathrm{m}$ $-52,5 \mu \mathrm{m}$ de comprimento por 10,37 $\mu \mathrm{m}$ de largura) (Fig. 13-G); células comuns da epiderme da face abaxial predominantemente retangulares ou trapezoides, $(8,07 \mu \mathrm{m}-20,65 \mu \mathrm{m}$ de comprimento por 12,65 $\mu \mathrm{m}$ de largura) (Fig. 13-H); câmaras subestomáticas ausentes (Fig. 13-H); complexo estomático tetracítico, estômatos dispostos regularmente em fileiras (Fig. 13-H); células-guarda mais compridas que largas $(19,05 \mu \mathrm{m}$ de comprimento e $5,75 \mu \mathrm{m}$ de largura) com formato reniforme (Fig. 13-H); células subsidiárias polares com formato trapezoides (Fig. 13-H); células subsidiárias laterais com formato reniforme (Fig. 13-H); pinas hipoestomáticas (Figs. 13-G e 13-H). 

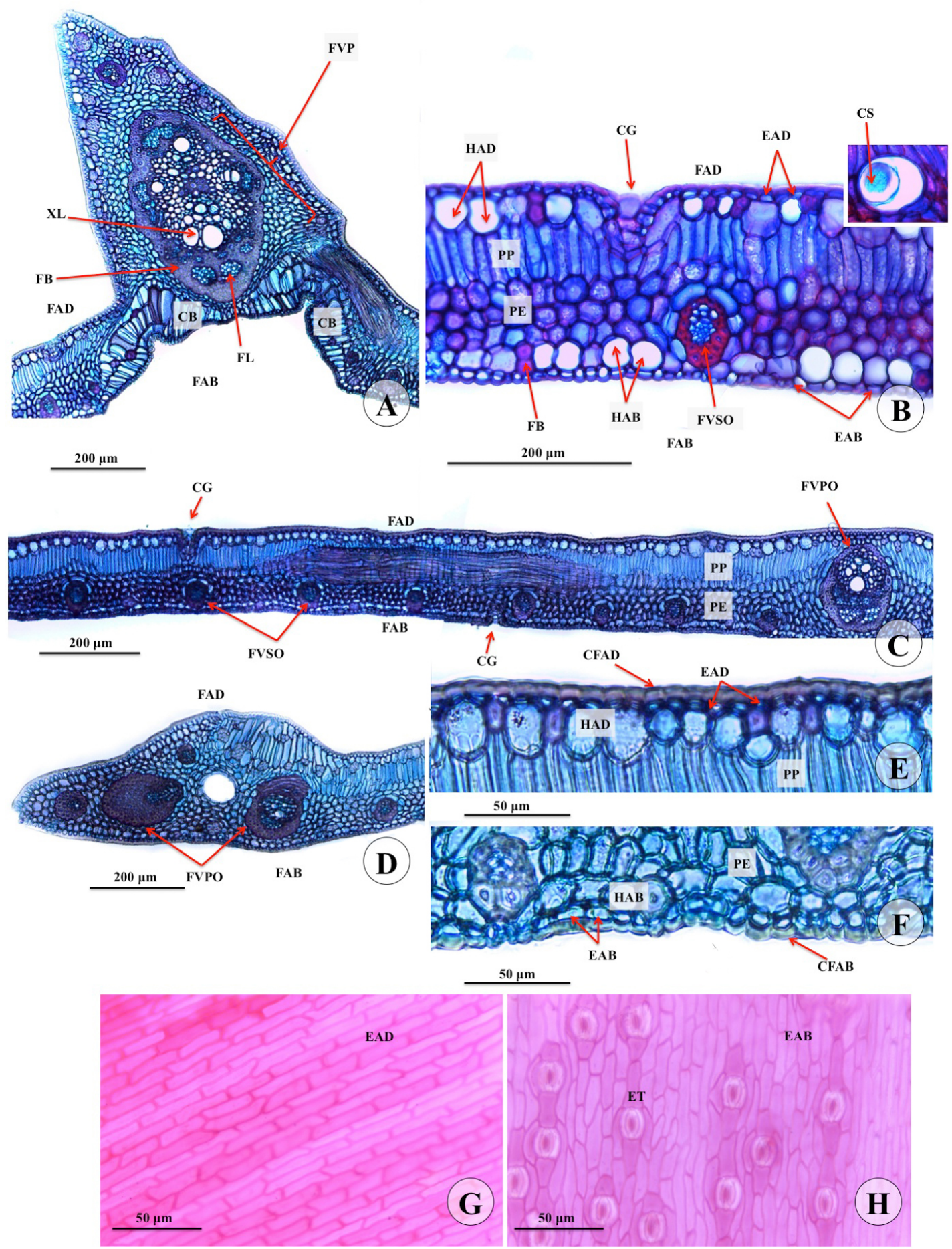

Figura 13. Anatomia foliar de Attalea maripa (Aubl. Mart.). A-F: Secções transversais; G-H: Cortes paradérmicos. A. Segmento foliar com a nervura principal com formato triangular e ângulo agudo: FVP- Feixe vascular principal, XL - Xilema, FL-Floema, FB - Fibras, CB - células buliformes, FAD - Face adaxial, FAB Face abaxial. B. Ampliação da lâmina foliar: FAD - Face adaxial, FAB - Face abaxial, HAD - Hipoderme da face adaxial, HAB - Hipoderme da face abaxial, FB - Fibras, EAD - Epiderme da face adaxial, EAB - Epiderme da face abaxial, PP- Parênquima Paliçádico, PE-Esponjoso, FVSO -Feixe vascular de segunda ordem, CS-Corpo silicoso em destaque. C. Padrão dos feixes vasculares na lâmina foliar: FAD - Face adaxial, FAB - Face abaxial, FVPO-Feixe vascular de primeira ordem, FVSO - Feixe vascular de segunda ordem. D. Margem foliar com ângulos arredondados. E. Ampliação da face adaxial: CFAD - Cutícula da face adaxial, EAD- epiderme da face adaxial. F. Ampliação da face abaxial: CFAB - Cutícula da face abaxial, EAB-epiderme da face adaxial. G. Epiderme da face adaxial. H. Epiderme da face abaxial com disposição dos estômatos em fileiras. ET: Estômatos. Escalas: A- D: $200 \mu \mathrm{m}$. E-H: $50 \mu \mathrm{m}$. 
Attalea phalerata

Feixe vascular principal colateral, ovoide, livre ou semi-travado, tanto adaxial quanto abaxialmente, envolto em de feixe de fibras extraxilemáticas, região da nervura principal com formato triangular com angulo agudo; protoxilema voltado para a face adaxial; floema permeando o xilema abaxialmente e adaxialmente (Fig. 14-A); células buliformes retangulares, em grupos 3-4 vezes mais largo que alto, 3 camadas celulares (Fig. 14-A); grupos de fibras permeando as células buliformes (Fig. 14-A); mesofilo dorsiventral, 6-8 camadas de células (135,25 $\mu \mathrm{m}$ de espessura) (Fig. 14-B); parênquima paliçádico com 1 camadas de células, mais de 7 vezes mais altas do que largas (Fig. 14-B); parênquima lacunoso com células isodiamétricas (Fig. 14-B); hipoderme adaxial espessa (25,25 $\mu \mathrm{m}$ de espessura), células ovoides ou isodimétricas (Fig. 14-B); grupos de fibras localizadas entre a epiderme e a hipoderme adaxial (Fig. 14-B); hipoderme abaxial delgada (12,92 $\mu \mathrm{m}$ de espessura), células ovoides (Fig. 14-B); lâmina foliar plana adaxialmente e com ondulações abaxialmente (Fig. 14-C); grupos de fibras localizadas entre a epiderme e a hipoderme abaxial (Fig. 14-B); feixes vasculares de primeira ordem travados adaxialmente (Fig. 14-C); feixes vasculares de segunda ordem travados abaxialmente ou livres (Fig. 14-C); feixes vasculares de terceira ordem travados abaxialmente (Fig. 14-C); cicatriz de tricomas glandulares presentes em ambas as faces (Fig. 14-C); margem foliar com ângulos agudo ou obtuso, com 2-3 camadas células buliformes presentes na face abaxial (Fig. 14-D); epiderme uniestratificada (Figs. 14-E e 14-F); cutícula adaxial mediana $(6,75 \mu \mathrm{m})$ (Fig. 14-E); células comuns da epiderme da face adaxial predominantemente retangulares $(21,7 \mu \mathrm{m}-34,0 \mu \mathrm{m}$ de comprimento por 10,4 $\mu \mathrm{m}$ de largura) (Fig. 14-G); cutícula abaxial delgada $(4,57 \mu \mathrm{m})$ (Fig. 14-F); células comuns da epiderme da face abaxial com células retangulares, trapezoides e em formato de losango $(41,5 \mu \mathrm{m}-60,0 \mu \mathrm{m}$ de comprimento por $16.85 \mu \mathrm{m}$ de largura) (Fig. 14-H); câmaras subestomáticas ausentes; complexo estomático tetracítico, estômatos dispostos regularmente em fileiras (Fig. 14-H); células-guarda 12 vezes mais compridas que largas $(23,27 \mu \mathrm{m}$ de comprimento e 6,27 $\mu \mathrm{m}$ de largura) (Fig. 14-H); células subsidiárias laterais reniformes (Fig. 14-H); células subsidiárias polares com formato ou reniformes (Fig. 14-H); pinas hipoestomáticas (Figs. 14-G e 14-H). 

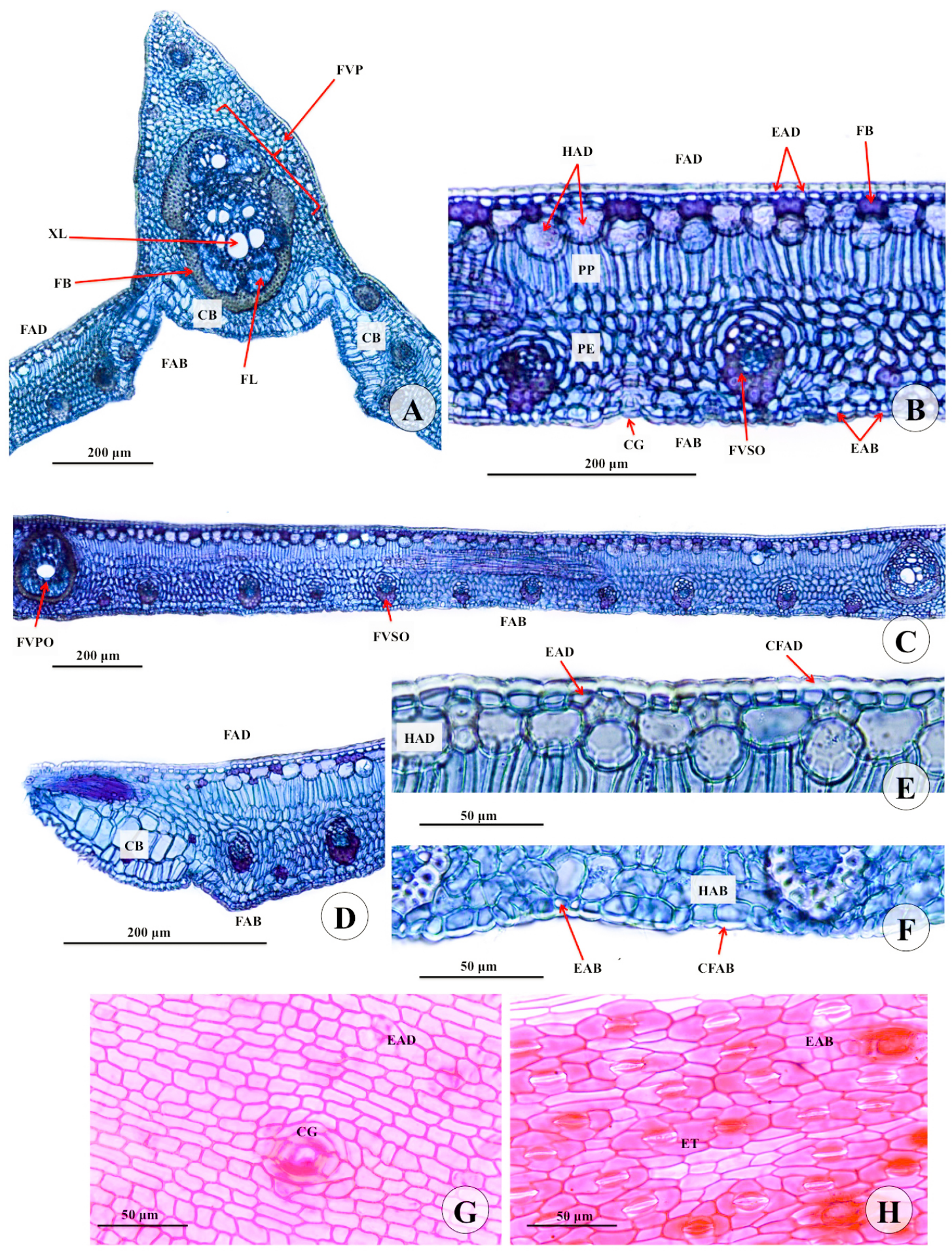

Figura 14. Anatomia foliar de Attalea phalerata (Mart. ex Spreng.). A-F: Secções transversais; G-H: Cortes paradérmicos. A. Segmento foliar com a nervura principal com formato triangular e ângulo agudo: FVP- Feixe vascular principal, XL - Xilema, FL-Floema, FB - Fibras, CB - células buliformes, FAD - Face adaxial, FAB Face abaxial. B. Ampliação da lâmina foliar: FAD - Face adaxial, FAB - Face abaxial, HAD - Hipoderme da face adaxial, HAB - Hipoderme da face abaxial, FB - Fibras, EAD - Epiderme da face adaxial, EAB - Epiderme da face abaxial, PP- Parênquima Paliçádico, PE-Esponjoso, FVSO -Feixe vascular de segunda ordem. C. Padrão dos feixes vasculares na lâmina foliar: FAD - Face adaxial, FAB - Face abaxial, FVPO-Feixe vascular de primeira ordem, FVSO - Feixe vascular de segunda ordem. D. Margem foliar com ângulos arredondados e presença de células buliformes, $\mathrm{CB}$ - células buliformes. E. Ampliação da face adaxial: CFAD - Cutícula da face adaxial, EAD- epiderme da face adaxial. F. Ampliação da face abaxial: CFAB - Cutícula da face abaxial, EABepiderme da face adaxial. G. Epiderme da face adaxial, CG- Cicatriz glandular. H. Epiderme da face abaxial com disposição dos estômatos em fileiras. ET: Estômatos. Escalas: A- D: $200 \mu \mathrm{m}$. E-H: 50 um. 


\section{Attalea vitrivir}

Feixe vascular principal colateral, ovoide, livre tanto adaxial quanto abaxialmente, envolto em feixe de fibras extraxilemáticas (Fig. 15-A); região da nervura principal com formato trapezoide e extremidades arredondadas (Fig. 15-A); protoxilema voltado para a face adaxial; floema permeando o xilema abaxialmente e adaxialmente (Fig. 15-A); células buliformes retangulares, em grupos 3-4 vezes mais largo que alto, 3 camadas celulares (Fig. 15-A); grupos de fibras permeando as células buliformes (Fig. 15-A); mesofilo dorsiventral, 10-12 camadas de células (199 $\mu \mathrm{m}$ de espessura) (Fig. 15-B); parênquima paliçádico com 2 camadas de células, mais de 10 vezes mais altas do que largas (Fig. 15-B); parênquima lacunoso com células isodiamétricas (Fig. 15-B); hipoderme adaxial espessa (50,2 $\mu \mathrm{m}$ de espessura), células ovoides ou isodiamétricas (Fig. 15-B); grupos de fibras localizadas entre a epiderme e a hipoderme adaxial (Fig. 15-B); hipoderme abaxial espessa (18,1 $\mu \mathrm{m}$ de espessura), células ovoides ou isodimétricas (Fig. 15-B); grupos de fibras localizadas entre a epiderme e a hipoderme abaxial (Fig. 15-B); lâmina foliar com ondulações tanto adaxialmente quanto abaxialmente (Fig. 15-C); feixes vasculares de primeira ordem travados adaxialmente (Fig. 15-C); feixes vasculares de segunda ordem travados abaxialmente ou livres (Fig. 15-C); feixes vasculares de terceira ordem livres (Fig. 15-C); cicatriz de tricomas glandulares presentes em ambas as faces (Fig. 15-C); margem foliar com ondulações na face abaxial e presença de feixes vasculares de segunda e terceira ordem (Fig. 15-D); epiderme uniestratificada (Figs. 15-E e 15-F); cutícula adaxial espessa (8,13 $\mu \mathrm{m})$ (Fig. 15-E); células comuns da epiderme da face adaxial retangulares $(19,17 \mu \mathrm{m}-32,0 \mu \mathrm{m}$ de comprimento por 13,7 $\mu \mathrm{m}$ de largura) (Fig. 15-E); cutícula abaxial espessa (7,35 $\mu \mathrm{m})$ (Fig. 15-F); células comuns da epiderme da face abaxial predominantemente retangulares ou trapezoides $(11,52 \mu \mathrm{m}-16,75 \mu \mathrm{m}$ de comprimento por 11,52 $\mu \mathrm{m}$ de largura) (Fig. 15-F); câmaras subestomáticas presentes (Fig. 15-F); complexo estomático tetracítico, estômatos dispostos regularmente em fileiras (Fig. 15-H); célulasguarda 1-2 vezes mais compridas que largas (21,15 $\mu \mathrm{m}$ de comprimento e 6,22 $\mu \mathrm{m}$ de largura) (Fig. 15-H); células subsidiárias laterais reniformes (Fig. 15-H); células subsidiárias polares com formato reniformes (Fig. 15-H); pinas hipoestomáticas (Figs. 15-G e 15-H). 

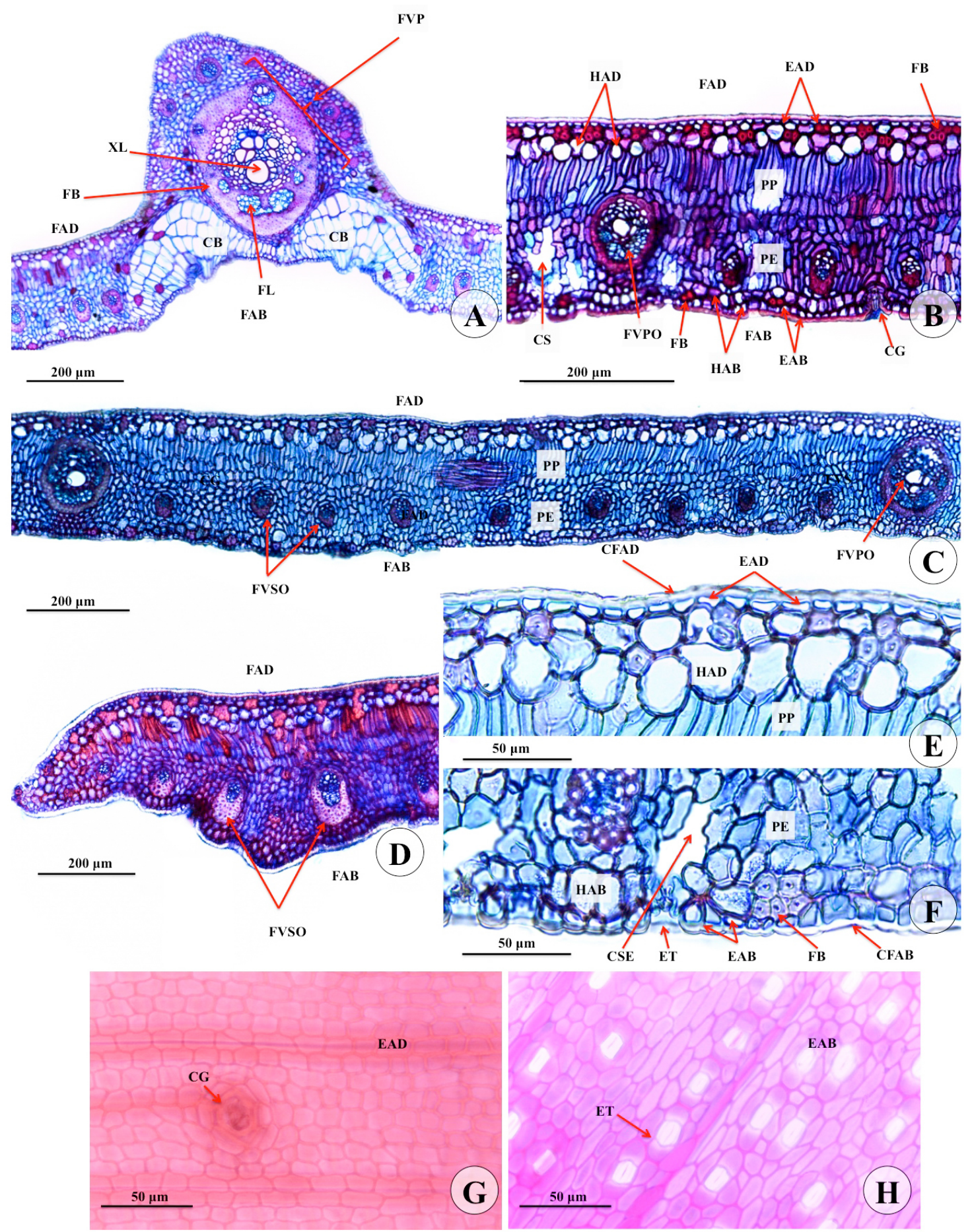

Figura 15. Anatomia foliar de Attalea vitrivir (Burret). A-F: Secções transversais; G-H: Cortes paradérmicos. A. Segmento foliar com a nervura principal com formato trapezoide e ângulos arredondados: FVP- Feixe vascular principal, XL - Xilema, FL-Floema, FB - Fibras, CB - células buliformes, FAD - Face adaxial, FAB - Face abaxial. B. Ampliação da lâmina foliar: FAD - Face adaxial, FAB - Face abaxial, HAD - Hipoderme da face adaxial, HAB - Hipoderme da face abaxial, FB - Fibras, EAD - Epiderme da face adaxial, EAB - Epiderme da face abaxial, PP- Parênquima Paliçádico, PE-Esponjoso, FVSO -Feixe vascular de segunda ordem, CS- câmaras subestomáticas, CG- Cicatriz glandular. C. Padrão dos feixes vasculares na lâmina foliar: FAD - Face adaxial, FAB - Face abaxial, FVPO-Feixe vascular de primeira ordem, FVSO - Feixe vascular de segunda ordem. D. Margem foliar com ondulações na face abaxial. E. Ampliação da face adaxial: CFAD - Cutícula da face adaxial, EAD- epiderme da face adaxial. F. Ampliação da face abaxial: CFAB - Cutícula da face abaxial, EAB- epiderme da face adaxial. G. Epiderme da face adaxial, CG- Catriz glandular. H. Epiderme da face abaxial com disposição dos estômatos em fileiras. ET: Estômatos. Escalas: A- D: 200 um. E-H: 50 um. 


\section{DISCUSSÃO}

Os caracteres anatômicos foliares se mostraram taxonomicamente informativos e podem ser utilizados para a classificação das sete espécies de Attalea analisadas, assim como já foi registrado para outros gêneros de palmeira (SILVA \& POTIGUARA, 2008; TOMLINSON et al., 2011; PINEDO et al., 2016).

Ondulações na superfície adaxial e abaxial foram encontradas em todas as espécies estudadas, exceto na face adaxial de $A$. speciosa e $A$. phalerata. As sete espécies observadas apresentaram epiderme unisseriada nas duas faces. $\mathrm{Na}$ face adaxial, as células epidérmicas apresentaram forma retangular ou trapezoides, com paredes retas, exceto em A. speciosa que apresentou ondulações. Ambas as faces são revestidas por uma cutícula espessa, sendo a cutícula da face adaxial mais espessa que a da face abaxial em todas as espécies.

Algumas características anatômicas são comuns a todas as espécies analisadas, tais como, cicatrizes de tricomas tectores glandulares, em ambas as epidermes adaxial e abaxial; mesofilo dorsiventral e complexo estomático tetracítico. Esse complexo foi observado nas sete espécies de Attalea analisadas e é tido como típico de palmeiras (caracterizados por possuir quatro células subsidiárias, duas delas paralelas às células-guarda e o par restante com localização polar ao estômato). Embora Tomlinson e colaboradores (2011) tenham relatado que os estômatos das palmeiras não necessariamente ocorram em fileiras longitudinais regulares e contínuas, este padrão foi observado em todas as espécies deste estudo.

Ademais, todas as espécies são hipoestomáticas, com exceção de A. barreirenses, que é anfiestomática, apresentando estômatos em ambas as faces. Esta classificação corrobora o trabalho de Santos e colaboradores (2011). Podem ocorrer células geminadas: célula subsidiária polares comum a dois estômatos. As células subsidiárias laterais das sete espécies apresentaram formato reniforme. As células subsidiárias polares das espécies A. speciosa, A, barreirensis, A. eichleri, A. phalerata e $A$. vitrivir apresentaram formato reniforme, enquanto que as células subsidiárias polares das espécies $A$. funifera e $A$. maripa apresentaram formato trapezoide.

O número de camadas do parênquima paliçádico variou de uma (A. speciosa, A. funifera, A. maripa e $A$. phalerta) a três (A. barreirensis, A. eichleri e A. vitrivir) e o parênquima esponjoso quatro a oito camadas, onde estão dispostos feixes fibrosos e fibrovasculares. O parênquima paliçádico em seção transversal, apresenta células alongadas, com forma de barras e dispostas em fileiras com espaços intercelulares reduzidos, exceto nas regiões subjacentes às células estomáticas, 
onde as lacunas delimitam câmaras subestomáticas em algumas espécies. As células do tecido esponjoso são isodiamétricas, ocorrendo esporadicamente células de aspecto retangular.

A nervura central possui um tecido de expansão, multiestratificado, com aproximadamente três-quatro camadas denominadas células buliformes. A presença desse tecido de expansão está relacionada com mecanismos de flexibilidade das pinas. Essas estruturas são conspícuas, ocorreram apenas na face abaxial e ocuparam quase toda a espessura da lâmina foliar, corroborando as observações realizadas para a tribo Cocoseae apresentadas por Tomlinson (1961).

O sistema vascular é formado, exclusivamente, de xilema e floema primários e periciclo. $\mathrm{O}$ periciclo apresenta-se como fibras. O feixe vascular é rodeado por uma grossa camada de fibras extraxilemáticas. A nervura central em secção transversal apresenta-se mais proeminente adaxialmente, situando-se na região mediana do limbo das pinas. Feixes vasculares colaterais (secundários e terciários) localizam-se principalmente no parênquima lacunoso, embora os de dimensões maiores adentrem o paliçádico. Alguns desses feixes colaterais encontravam-se travados. O número de feixes colaterais entre os feixes primários não podem ser utilizados para separar as espécies estudadas, pois pode variar dentro de uma mesma espécie.

As nervuras possuem floema indiviso voltado à face abaxial e xilema à adaxial. Os feixes vasculares secundários e terciários de $A$. barreirensis e $A$. vitrivir são livres tanto abaxialmente quanto adaxialmente, no entanto, os feixes primários são travados em pelo menos uma das faces. Tais observações estão em acordo com o apresentado por Tomlinson e colaboradores (2011), que afirmam que os feixes longitudinais encontram-se em contato com uma ou ambas as faces epidérmicas em Attaleinae.

A hipoderme, em geral, apresentou-se bem desenvolvida e mais espessa que a epiderme, tanto adaxial quanto abaxialmente, o mesmo foi observado por Tomlinson e colaboradores (2011) para o gênero Cocos. Comparadas às células hipodérmicas, as células epidérmicas das palmeiras são quase sempre mais delgadas (TOMLINSON et al., 2011).

De uma maneira geral, as fibras apresentaram-se abundantes, com padrões de organização distintos na hipoderme, conforme apontado por Tomlinson (1961) para a tribo Cocoseae. De acordo com Tomlinson e colaboradores (2011), as fibras em Attaleinae encontram-se sempre associadas a uma das faces hipodérmicas, podendo situar-se interna ou externamente a essa estrutura. Neste trabalho, observou-se que em A. eichleri e A. funifera apresentaram feixes de fibras situados somente na hipoderme adaxial, enquanto que A. speciosa, A. barreirensis, A. phalerata, A. maripa e A. vitrivir 
os feixes foram encontrados tanto na hipoderme adaxial quanto na hipoderme abaxial. Em todas as sete espécies as fibras estavam situadas internamente à hipoderme.

Os formatos das secções foliares transversais onde se encontram as nervuras principais é de grande valor taxonômico para as espécies estudadas. Attalea barreirensis, A. funifera e A vitrivir apresentaram formato trapezoide com extremidade arredondadas. As espécies $A$. speciosa e $A$. eichleri apresentaram formato trapezoide com extremidade aguda. Já as espécies $A$. phalerata e $A$. maripa apresentaram formato triangular (Figura 16). A margem foliar e a localização dos feixes vasculares e dos grupos de fibras com relação à margem variaram muito entre as espécies. A espécie A. phalerata apresentou células buliformes em sua extremidade abaxial.

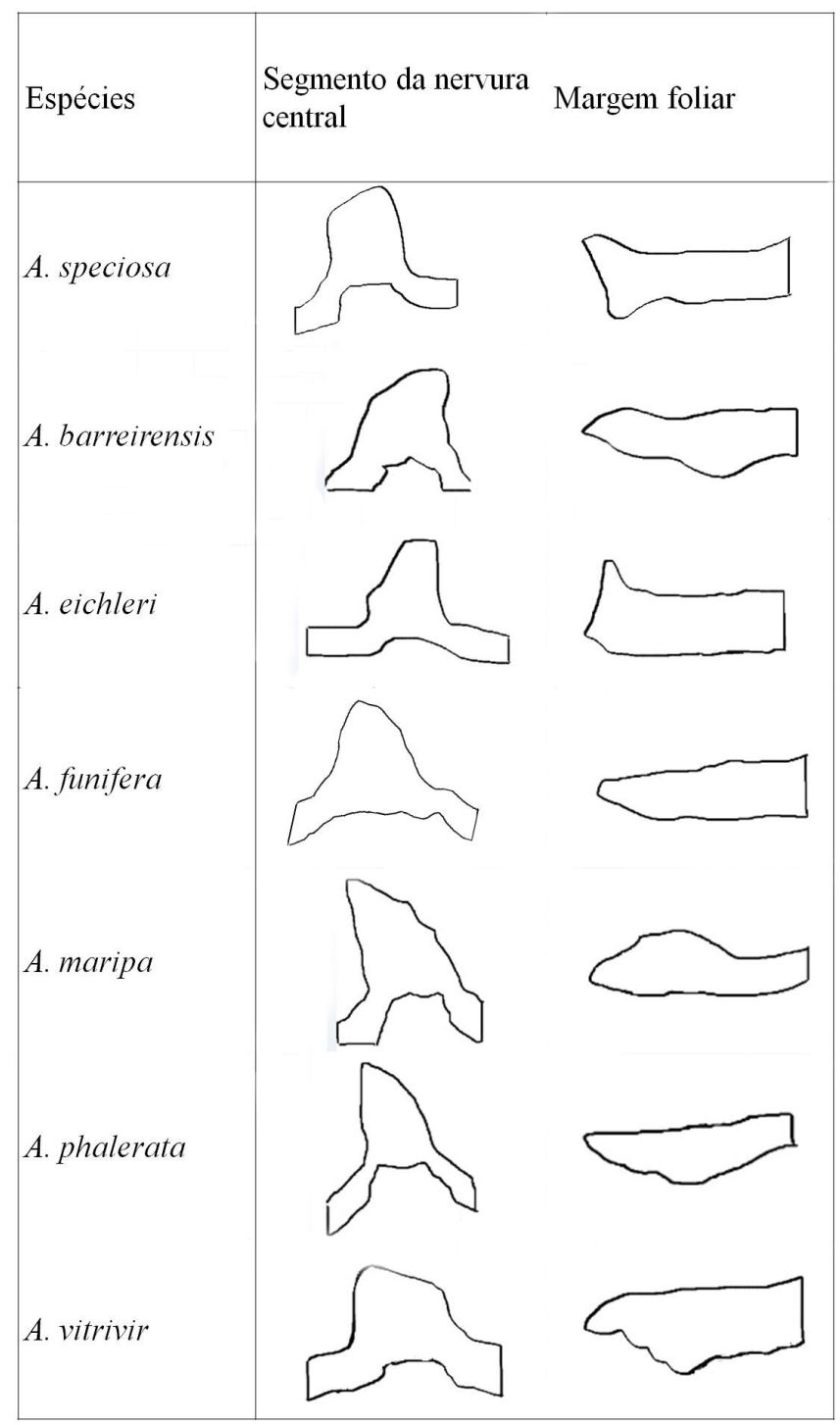

Figura 16. Formas das secções foliares transversais onde se encontram as nervuras principais e formas das margens foliares das espécies Attalea estudadas. 
Foram observados corpos silicosos somente em A. maripa. Essa constatação está em acordo com Tomlinson (2011), que observou que os tecidos de palmeiras são frequentemente muito fibrosos, fortemente lignificados e com frequente ocorrência de corpos de sílica.

A similaridade entre as amostras estimada pelo coeficiente de Jaccard através do dendograma obtido pelo programa NTSYS-pc pode ser observada na Figura 17.

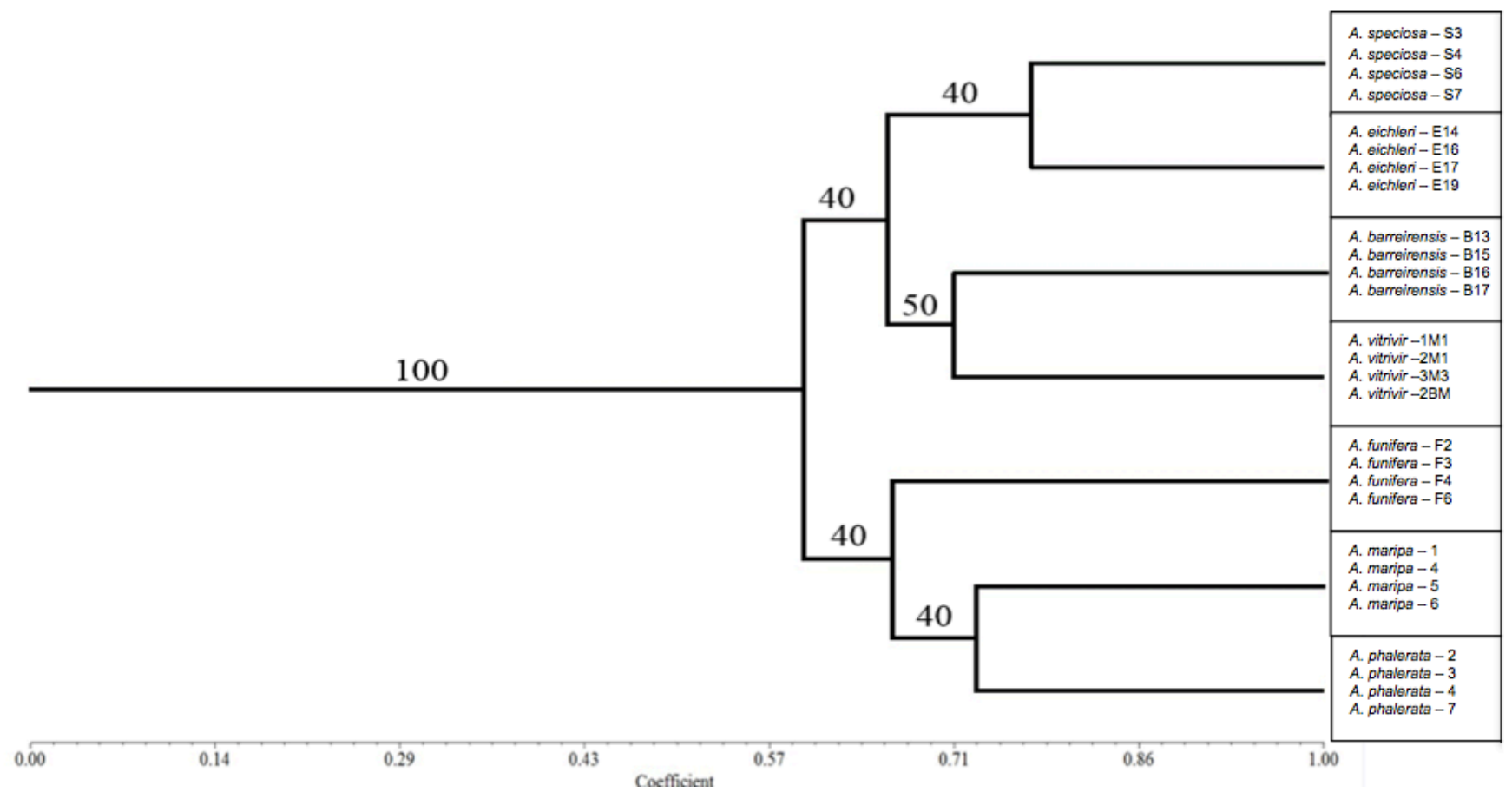

Figura 17. Dendograma gerado pelo método UPGMA para o coeficiente de JACCARD para os dados morfológicos obtidos através da anatomia foliar das espécies $A$. speciosa, $A$. barreirensis, $A$. eichleri, A. funifera, A. maripa, A. phalerata e A. vitrivir.

Analisando-se o dendograma, observa-se uma maior similaridade entre as espécies $A$. speciosa e $A$. eichleri, entre as espécies $A$. vitrivir e $A$. barreirensis e entre as espécies $A$. maripa e $A$. phalerata. Observa-se também o agrupamento das espécies A. speciosa, A. eichleri, A. barreirensis e A. vitrivir, assim como o agrupamento das espécies $A$. funifera, A. maripa e A. phalerata em dois grupos distintos. Contudo, nenhuma destas similaridades entre estas espécies foi observada na revisão que Pintaud (2008) e colaborades realizaram entre os autores Glassman 1999, Henderson e colaboradores (1995) e Govaerts e Dransfield (2005). 


\section{CONCLUSÃO}

A anatomia foliar das sete espécies estudadas do gênero Attalea foi altamente informativa. Os dados gerados podem auxiliar na identificação das espécies, assim como na classificação taxonômica das mesmas.

Os caracteres anatômicos foliares descritos foram suficientes para distinguir as sete espécies analisadas. No entanto, levando-se em consideração o complexo babaçu e a alta diversidade de espécies e quantidade de híbridos, são necessários mais estudos anatômicos foliares para se estimar com maior confiabilidade a relação entre as espécies deste gênero. 


\section{CAPÍTULO 2}

APLICAÇÃO E AVALIAÇÃO DE DNA BARCODE EM ESPÉCIES DO COMPLEXO BABAÇU (Attalea spp.) 


\section{RESUMO}

O babaçu (Attalea spp.) é uma palmeira nativa, com ampla distribuição no Nordeste do Brasil e no sul da Bacia Amazônica e é um importante recurso natural na região. É um dos principais produtos extrativistas do país, contribuindo significativamente para a economia de alguns estados brasileiros. A identificação taxonômica do conjunto de espécies de babaçu é complexa, e não há consenso entre os diversos autores, por isso, esse conjunto de espécies é denominado "complexo babaçu". A existência de híbridos naturais entre espécies, o baixo número de coleções feitas e baixo número de estudos no gênero dificulta a identificação taxonômica correta dessas espécies. O sistema de identificação molecular por DNA barcode auxilia na identificação rápida e eficiente das espécies. Foram realizados estudos com DNA barcode em sete espécies de babaçu: A. speciosa, A. barreirensis, A. eichleri, A. funifera, A. maripa, A. phalerata, A. vitrivir e híbridos de A. speciosa e A. eicchleri - A. teixeirana. As regiões do DNA analisadas foram: matK, rbcL, ITS, psbA-trnH, trnL e PRK. As árvores filogenéticas foram construídas utilizando-se os métodos de Inferência Bayesiana, Máxima Parcimônia e Máxima Verossimilhança. Sequências de DNA das mesmas regiões analisadas, de outras espécies de Attalea encontrada no GenBank foram acrescentadas na construção das árvores filogenéticas. Os marcadores $r b c L$, trnL e matK mostraram resolução insuficiente para a discriminação das espécies. Os marcadores $p s b A$-trnH, ITS e PRK mostraram resultados potencialmente satisfatórios para discriminar espécies de Attalea. O uso de DNA barcode em Attalea, no entanto, precisa ser aprimorado, na otimização de extração de DNA, PCR e protocolos de sequenciamento, bem como na escolha e a combinação dos marcadores utilizados.

Palavras-chave: Attalea, Babaçu, barcode, matK, rbcL, trnL, psbA-trnH, ITS e PRK 


\begin{abstract}
The babassu (Attalea spp.) is a native palm with wide distribution in Northeast Brazil and the south of the Amazon Basin and is an important natural resource in the region. It is one of the main extractive products of the country, contributing significantly to the economy of some Brazilian states. The morphological identification of babassu species is difficult and there is no clear taxonomic consensus among the various published monographs, so that the group is often referred to as the "babassu complex". The existence of natural hybrids between species, the low number of collections made and low number of studies in the genus hinders correct taxonomic identification of these species. Molecular identification in the form of DNA barcoding can assist in reliable and efficient identification of Attalea species. In the current work, the potential of DNA barcoding was investigated in seven babassu species: $A$. speciosa, $A$. barreirensis, $A$. eichleri, A. funifera, $A$. maripa, A. phalerata, A. vitrivir and hybrids of $A$. speciosa and A. eicchleri - A. teixeirana. The analyzed DNA loci were: matK, rbcL, ITS, psbA-trnH, trnL and PRK. Phylogenetic trees were constructed using Bayesian, Maximum Parsimony and Maximum Likelihood methods. Cognate DNA sequences from Attalea species were obtained from GenBank where available. The DNA barcode loci $r b c L$, $t r n L$ and matK showed insufficient resolution for discrimination of species. The $p s b A$-trnH markers, ITS and PRK showed potentially satisfactory results for discriminating Attalea species. The use of DNA barcodes in Attalea, however, needs to be improved, in the optimization of DNA extraction, PCR and and sequencing protocols, as well as the choice and combination of markers used.
\end{abstract}

Key words : Attalea, Babassu, barcode, matK, $r b c L, t r n L$, $p s b A$-trnH, ITS e PRK 


\section{INTRODUÇÃO}

Attalea é um dos gêneros de palmeiras mais importantes da região Neotropical. A identificação de espécies de Attalea, no entanto, tem sido difícil por várias razões, como a escassez de boas coleções de herbário e ao caráter sazonal das florações. Além destas razões, não há consenso na classificação entre os diversos autores (PINTAUD, 2008). O desenvolvimento de híbridos naturais entre as espécies, o baixo número de coletas e a pequena quantidade de estudos sobre o gênero também dificultam a correta identificação taxonômica dessas espécies (ANDERSON \& BALICK, 1988; PINTAUD, 2008).

A discriminação das espécies baseada em caracteres morfológicos apresenta limitações muito significativas. A plasticidade fenotípica e a variabilidade genética nos caracteres empregados para o reconhecimento de espécies podem levar a uma identificação incorreta (AZEREDO, 2005). A abordagem morfológica omite complexos críticos, caracterizados quando diferentes espécies apresentam a mesma morfologia. Além destas limitações, chaves morfológicas frequentemente são eficientes somente para um estágio do ciclo de vida e assim muitos indivíduos não podem ser identificados (AZEREDO, 2005). Estas limitações do sistema de identificação com bases morfológicas sinalizam a necessidade de uma nova abordagem para identificação de táxons (AZEREDO, 2005).

Hebert e colaboradores (2003) propuseram um sistema de identificação molecular conhecido por DNA barcode que consiste na utilização de uma pequena sequência de DNA para a discriminação de todas as espécies (CARVALHO et al., 2008).

A região de DNA barcode ideal deve atender a alguns critérios: a sequência do fragmento deve ser curta, para facilitar a amplificação e o sequenciamento; deve apresentar variabilidade suficiente para separar as espécies; e deve apresentar sítios conservados para o desenvolvimento de primers universais (FORD et al., 2009). O propósito do DNA barcode não é solucionar relações filogenéticas, mas utilizar análises filogenéticas para a detecção de grupos monofiléticos e consequente delineação das espécies (NELSON et al., 2007).

Este trabalho teve por objetivo identificar marcadores moleculares barcode eficientes na discriminação de sete espécies do complexo babaçu: A. speciosa, A. barreirensis, A. eichleri, A. funifera, A. maripa, A. phalerata e A. vitrivir, do híbrido A. teixeirana (hibrido entre $A$. speciosa e $A$. eichleri) e analisar esses resultados através dos métodos de distância de Kimura 2-parâmetros (K2P), inferência bayesiana (IB), máxima parcimônia (MP) e máxima verossimilhança (MV). 


\section{MATERIAL E MÉTODOS}

O estudo de DNA barcode foi desenvolvido no Laboratório de Genética Vegetal da Embrapa Recursos Genéticos e Biotecnologia.

\section{Amostragem}

Foram utilizadas amostras de folhas coletadas em campo, que foram armazenadas com sílica após a coleta. O resumo das informações das amostras coletadas em campo utilizadas neste estudo encontram-se na Tabela 5, informações mais detalhadas se encontram na tabela 15, Anexo II (páginas 93-95). Foram utilizadas também amostras foliares retiradas de exsicatas (Tabela 6). Sequências de Attalea, assim como as sequências de outgroups (Cocos nucifera) utilizadas nas análises foram obtidas do GenBank (Tabela 7).

Tabela 5. Tabela de amostras de espécies babaçu coletadas com suas respectivas origens utilizadas neste estudo.

\begin{tabular}{|c|c|}
\hline A. teixeirana - híb-BA1 & Perinã. Localidade: Grajaú, MA. \\
\hline A. teixeirana - híb-BA4 & "eichleri grande". Localidade: Grajaú, MA. \\
\hline A. teixeirana - híb - BA39 & "speciosa alta". Localidade: Grajaú, MA. \\
\hline A. teixeirana - híb-CT22 & Intermediária entre pindova e "eichleri grande". Localidade: Caxias, MA. \\
\hline A. teixeirana- híb-CT01 e CT02 & Pindova, acaule. Localidade: Caxias, MA. \\
\hline A. teixeirana - híb-CT02 & Pindova, acaule. Localidade: Caxias, MA. \\
\hline A. teixeirana-híb-CT16 e CT20 & "eichleri grande". Localidade: Caxias, MA. \\
\hline A. teixeirana - híb-CT37 & Pindova. Localidade: Caxias, MA. \\
\hline A. teixeirana - híb-CT38 & "eichleri grande". Localidade: Caxias, MA. \\
\hline A. teixeirana - híb - LA19 & "speciosa baixa", talvez perinã. Localidade: Lajeado Novo, MA. \\
\hline A. teixeirana - híb - FZ12 & Localidade: Grajaú, MA. \\
\hline A. barreirensis - Amostras B1- B17 & População (pop. 21). Localidade: São Raimundo das Mangabeiras, MA. \\
\hline A. eichleri- E04, E17, E18, E18, E19, E11 & População (pop. 18). Localidade: Carolina, MA. \\
\hline A. eichleri-CT07 & População (pop. 18). Localidade: Carolina, MA. \\
\hline A. eichleri-ES22 & Localidade: Estreito, MA. \\
\hline A. funifera $-1-15$ & Coleção particular do Carlos Alex na Bahia \\
\hline A. maripa-1- 12 & Coleção particular do Carlos Alex na Bahia \\
\hline A. phalerata $-\mathrm{P} 12$ & População (pop.15). Localidade: Tocantinópolis, TO. \\
\hline A. phalerata- $\mathrm{P} 30, \mathrm{P} 36$ & População (pop.17). Localidade: Carolina, MA. \\
\hline A. speciosa-CT46 e CT47 & Localidade: Caxias, MA. \\
\hline A. speciosa-S3, S4, S5,S6, S7, S8, S9 e S17 & População (pop.12). Localidade: Nazaré, TO. \\
\hline A. vitrivirir - 1BM, $2 \mathrm{BM}$ e $8 \mathrm{BM}$ & $\begin{array}{l}\text { Bonito de Minas (MG), próximo de Montes Claros - Fornecido pela } \\
\text { Universidade Estadual de Montes Claros }\end{array}$ \\
\hline A. vitrivirir - $1 \mathrm{M} 1 \mathrm{e} 2 \mathrm{M} 1$ & $\begin{array}{l}\text { Montalvânia - MG - Divisa de MG com o sul da Bahia - Fornecido pela } \\
\text { Universidade Estadual de Montes Claros }\end{array}$ \\
\hline
\end{tabular}


Tabela 6. Amostras de herbário utilizadas no estudo.

\begin{tabular}{|c|c|c|}
\hline \multirow[b]{2}{*}{ Espécies } & \multicolumn{2}{|l|}{ Amostras de Herbário } \\
\hline & Universidade de Brasília - UnB (UB) & Embrapa Cenargen (CEN) \\
\hline A. barreirensis & $\mathrm{n}^{\circ} 36868$ - W.R. Anderson, M.S. Stiebis, J.H. Kinkbride Jr. - 1972 & $\mathrm{n}^{\circ}$ 52072-A.O. Scariot \\
\hline A. eichleri & $\mathrm{n}^{\circ} 1091$ - R.C. Martins, M.S. Oliveira - 2010 & $\mathrm{n}^{\circ} 52073$ - A.O. Scariot - 2002 \\
\hline A. maripa & - & $\mathrm{n}^{\circ} 12546$ - A.O. Scariot - 1988 \\
\hline A. phalerata & $\mathrm{n}^{\circ} 238$ - R.C. Martins, T. Figueira - 1998 & $\mathrm{n}^{\circ} 56852$ - R.F.Viera et al.. - 1473 \\
\hline A. speciosa & n 10110 D. Mítiga, R.C. Martins - 2006 & $\mathrm{n}^{\circ} 58039-$ M.J Balick et al. \\
\hline A. vitrivir & - & $\mathrm{n}^{\circ} 10759-$ J.G. Vieira -1980 \\
\hline
\end{tabular}

Tabela 7. Sequências retiradas do GenBank para a construção das árvores

\begin{tabular}{|c|c|c|c|c|c|c|c|}
\hline \multirow[b]{2}{*}{ Espécies } & \multicolumn{7}{|c|}{$\mathrm{N}^{\circ}$ do acesso no GenBank } \\
\hline & ITS & matK & $p s b A-\operatorname{trn} H$ & $r b c L$ & PRK & RPB2 & $\operatorname{trn} L$ \\
\hline A. allenii & - & AM114636. 1 & - & AJ404829. 1 & AJ831346. 1 & AJ830207 & AJ241312. 1 \\
\hline A. butyracea & - & JQ586691. 1 & - & JQ590420. 1 & - & - & - \\
\hline A. cohune & - & - & - & - & AY601239. 1 & - & - \\
\hline A. crassispatha & - & - & - & - & - & - & AJ241321.1 \\
\hline A. cuatrecasana & - & - & - & - & AY601241. 1 & - & - \\
\hline A. oleifera & - & - & - & - & AY601238. 1 & - & - \\
\hline A. phalerata & - & *HQ265548. 1 & KC924913. 1 & - & AY601240. 2 & HQ265644. 1 & HQ265783. 1 \\
\hline A. rostrata & - & GQ981943. 1 & GQ982156. 1 & GQ981675. 1 & - & - & - \\
\hline A. speciosa & - & - & KC924916. 1 & - & AY601245.1 & - & - \\
\hline C. nucifera & HQ265515.1 & HQ265564. 1 & GQ435464. 1 & AY012507. 1 & AY601235. 1 & EF491150. 1 & AM113647. 1 \\
\hline
\end{tabular}

*Sequência de Attalea referenciada no CBOL.

\section{Extração de DNA}

Para os estudos de DNA barcode foi realizada a extração do DNA genômico das amostras de babaçu coletadas em campo e das amostras fornecidas pelos herbários de acordo com o protocolo CTAB (DOYLE \& DOYLE, 1987), adaptado. Primeiramente as folhas foram trituradas com Mini beadbeater (Biospec Products Inc.) e incubadas por 45 minutos a $65^{\circ} \mathrm{C}$ em uma solução com $700 \mu \mathrm{L}$ de CTAB $2 \%$ e $1 \%$ de $\beta$-mercaptoetanol. O CTAB lisa as membranas e o $\beta$-mercaptoetanol inibe a oxidação do material. Posteriormente, adicionou-se CIA (clorofórmio: álcool isoamílico, 24:1), foi feita homogeneização da solução e centrifugação para separação em duas fases. O CIA promove a extração dos lipídios, proteínas e polissacarídeos, que permanecem na fase inferior, enquanto que o DNA permanece na fase aquosa, superior. O DNA foi precipitado em álcool isopropílico e lavado com etanol. Ao final foi ressuspenso em $100 \mu \mathrm{L}$ de solução tampão Tris-EDTA e RNase (proporção de $1 \mathrm{~mL}: 2 \mu \mathrm{L}$, respectivamente). 


\section{Quantificação do DNA}

Os produtos da extração foram quantificados através de eletroforese horizontal em gel de agarose $1 \%$, corado com brometo de etídio e visualizados em transiluminador de luz ultravioleta (UV). A qualidade do DNA extraído foi avaliada visualmente e sua concentração estimada por comparação com uma amostra de DNA com concentração conhecida (DNA lambda).

\section{Reações de PCR (Polymerase Chain Reaction )}

Após a extração, quantificação e diluição do DNA, foi realizada a amplificação de regiões alvo por PCR com as regiões específicas definidas como potencialmente eficientes para discriminação de espécies. São elas: cloroplastidiais - matK, $r b c L$, $p s b A$-trnH, $\operatorname{trn} L$, e nucleares PRK, RPB2 e ITS. As sequêcias dos primers utilizados nas amplificações estão descritas na Tabela 8.

Tabela 8. Sequência e referência dos primers utilizados nas amplificações por PCR

\begin{tabular}{|c|c|c|}
\hline & Sequência & Referência \\
\hline \multirow{2}{*}{ matK } & 3F_Kim f (5' CGTACAGTACTTTTGTGTTTACGAG 3') & \multirow{2}{*}{ SUGITA et al.,1985; AVRAHAM et al., 1995} \\
\hline & 1R_kim r (5'ACCCAGTCCATCTGGAAATCTTGGTTC 3') & \\
\hline \multirow{2}{*}{$r b c L$} & $r b c L a \_\mathrm{f}\left(5^{\prime}\right.$ AGTTCACCACAAACAGAGACTAAAGC 3') & \multirow{2}{*}{$\begin{array}{c}\text { MORTON et al., 1993; KRESS \& } \\
\text { ERICKSON, } 2009\end{array}$} \\
\hline & $r b c L a \_\mathrm{r}\left(5^{\prime}\right.$ GTAAAATCAAGTCCACCCCRCG3') & \\
\hline \multirow{2}{*}{ psbA-trnH } & $p s b A$ (5' CGAAGCTCCATCTACAAATGG 3') & \multirow{2}{*}{ SANG et al., 1997} \\
\hline & $\operatorname{trnH}\left(5^{\prime}\right.$ ACTGCCTTGATCCACTTGGC 3') & \\
\hline \multirow{2}{*}{$\operatorname{trn} L$} & $\operatorname{trnL}$ F ( 5' CGAAATCGGTAGACGCTACG 3') & \multirow{2}{*}{ TABERLET et al., 1991} \\
\hline & $\operatorname{trnL}$ R (5' GGGGATAGAGGGACTTGAAC 3') & \\
\hline \multirow{2}{*}{ PRK } & prK F (5' GTGATATGGAAGAACGTGG 3') & \multirow{2}{*}{ LEWIS \& DOYLE, 2002} \\
\hline & prK R (5' ATTCCAGGGTATGAGCAGC 3') & \\
\hline \multirow{2}{*}{ RPB2 } & RPB2 F (5' CAACTTATTGAGTGCATCATGG 3') & \multirow{2}{*}{ LIU et al., 1999; RONCAL et al., 2005} \\
\hline & RPB2 R (5' CCACGCATCTGATATCCAC 3') & \\
\hline \multirow{2}{*}{ ITS } & ITS1 (5' TTCCGTAGGTGAACCTGCGG 3') & \multirow{2}{*}{ WHITE et al., 1990} \\
\hline & ITS4 (5' TCCTCCGCTTATTGATATGC 3') & \\
\hline
\end{tabular}

PCRs das regiões $p s b A$-trnH, matK, $r b c L$ e trnL

Para as PCRs dos marcadores $p s b A$-trnH, matK, $r b c L$, $\operatorname{trn} L-t r n F$, foi utilizado o seguinte protocolo, por reação: Tampão [(10X Platinum HF com Mg 600mM, Tris-SO4 (pH 8,9), 180mM $\left.\left.\left(\mathrm{NH}_{4}\right)_{2} \mathrm{SO}_{4}, 20 \mathrm{mM} \mathrm{MgSO} 4\right)\right]$ na concentração de $1 \mathrm{X}$; dNTPs a $0,2 \mathrm{mM}$; BSA a de 0,2 mg/mL; Primers forward e reverse a $0,25 \mu \mathrm{M}$ cada; O respectivo primer reverse na concentração de $0,25 \mu \mathrm{M}$; $1 \mathrm{U}$ de Taq DNA polimerase, DNA na concentração de $5 \mathrm{ng} / \mu \mathrm{L}$ e água ultrapura. O volume total de 
cada reação foi de 15,0 $\mu \mathrm{L}$. Foi utilizado o seguinte programa no termociclador: um ciclo inicial de 2 min a $95^{\circ} \mathrm{C}, 35$ ciclos de $30 \mathrm{~s}$ a $95^{\circ} \mathrm{C}, 1 \mathrm{~min}$ na temperatura de anelamento adequada, e $7 \mathrm{~min}$ a $72^{\circ} \mathrm{C}$, seguidos de um ciclo final de $1 \mathrm{~min}$ a $72^{\circ} \mathrm{C}$. A temperatura de anelamento para cada par de primer foi de $52^{\circ} \mathrm{C}$ para $p s b A$-trnH e $r b c L, 46^{\circ} \mathrm{C}$ para $m a t K, 54^{\circ} \mathrm{C}$ para $t r n L$.

\section{PCRs das regiões ITS, RPB2 e PRK}

Para as PCRs da região ITS, $R P B 2$ e $P R K$ foi utilizado o seguinte protocolo, por reação: Tampão [(10X Platinum HF com Mg 600mM, Tris-SO 4 (pH 8,9), 180mM (NH4)2 $\mathrm{SO}_{4}, 20 \mathrm{mM}$ $\left.\mathrm{MgSO}_{4}\right)$ ] na concentração de 1X; dNTPs na concentração de 0,2 mM; BSA na concetração de 0,2 $\mathrm{mg} / \mathrm{mL}$; O respectivo primer forward no concentração de $1,0 \mu \mathrm{M}$; O respectivo primer reverse no concentração de 1,0 $\mu \mathrm{M}$; $1 \mathrm{U}$ de Taq polimerase, DNA na concentração de $5 \mathrm{ng} / \mu \mathrm{L}$; Etilenoglicol na concentração de $6,66 \%$ e Trehalose na concentração de $3 \times 10^{-3} \mathrm{mM}$. O volume total de cada reação foi de $15,0 \mu \mathrm{L}$. Para o marcador ITS foi utilizado o seguinte programa no termociclador: um ciclo inicial de 2 min a $95^{\circ} \mathrm{C}, 35$ ciclos de $20 \mathrm{~s}$ a $95^{\circ} \mathrm{C}, 30 \mathrm{~s}$ a $60^{\circ} \mathrm{C}$ e $1 \mathrm{~min}$ a $72^{\circ} \mathrm{C}$ e um ciclo final $71 \mathrm{~min}$ a $72^{\circ} \mathrm{C}$. Para o marcador $P R K$ foi utilizado o seguinte programa no termociclador: um ciclo inicial de 2 min a $94^{\circ} \mathrm{C}, 35$ ciclos de $20 \mathrm{~s}$ a $94^{\circ} \mathrm{C}, 1 \mathrm{~min}$ a $56^{\circ} \mathrm{C}$ e $2 \mathrm{~min}$ a $72^{\circ} \mathrm{C}$ e um ciclo final de $7 \mathrm{~min}$ a $72^{\circ} \mathrm{C}$. Para o marcador RPB2 foi utilizado o seguinte programa no termociclador: um ciclo inicial de 2 min a $94^{\circ} \mathrm{C}, 35$ ciclos de $20 \mathrm{~s}$ a $94^{\circ} \mathrm{C}, 1 \mathrm{~min}$ a $54^{\circ} \mathrm{C}$ e $2 \min$ a $72^{\circ} \mathrm{C}$ e um ciclo final de $7 \mathrm{~min}$ a $72^{\circ} \mathrm{C}$.

A eficácia da amplificação foi avaliada em gel de agarose 1\%, corado com brometo de etídio e visualizados em transiluminador de luz ultravioleta (UV). O tamanho das sequências amplificadas em pares de base foi averiguado em comparação com marcador ladder $1 \mathrm{~Kb}$.

\section{Purificação dos produtos de PCR com as enzimas Exonuclease I (EXO I) e Shrimp Alkaline Phosphatase (SAP).}

Foi feita a purificação dos produtos de PCR com um coquetel contendo as enzimas EXO I para digerir o excesso de primers e SAP para degradar o excesso de nucleotídeos provenientes da PCR. Cada produto de PCR foi purificado com $2 \mu \mathrm{L}$ de solução contendo $0,725 \mu \mathrm{L}$ de Tris (pH 8, $50 \mathrm{mM}$ ); SAP na concentração de $0,25 \mathrm{U} / \mu \mathrm{L}$ e EXO I na concentração de $0,25 \mathrm{U} / \mu \mathrm{L}$ por $45 \mathrm{~min}$ a $37^{\circ} \mathrm{C}$, seguido de $20 \mathrm{~min}$ a $80^{\circ} \mathrm{C}$ para inativação das enzimas. 


\section{Reação de sequenciamento.}

As amplificações das fitas forward e reverse foram realizadas separadamente conforme o protocolo seguinte para cada reação: Tampão (10X) na concentração de 1,8 X; 0,5 $\mu \mathrm{L}$ de BigDye 3.1, (Applied Biosystems); 1,0 $\mu \mathrm{L}$ do produto da purificação com as enzimas Exo I e SAP; um dos primers utilizado para fazer a amplificação do gene barcode (uma reação com o primer do sentido forward e outra reação com o primer do sentido reverse) na concentração de $0,5 \mathrm{mM}$; e água ultrapura. O volume total de cada reação foi de $10,0 \mu \mathrm{L}$.

Para as PCRs realizadas com os primers de ITS foi utilizado o seguinte programa no termociclador: $96^{\circ} \mathrm{C}$ por $1 \mathrm{~min}, 35$ ciclos de $10 \mathrm{~s}$ a $96^{\circ} \mathrm{C}, 4 \mathrm{~min}$ a $60^{\circ} \mathrm{C}$. Para as PCRs realizadas com todos os outros primers foi utilizado o seguinte programa no termociclador: $96{ }^{\circ} \mathrm{C}$ por 1 min, 35 ciclos de $10 \mathrm{~s}$ a $96^{\circ} \mathrm{C}, 15 \mathrm{~s}$ a $50^{\circ} \mathrm{C}$ e 4 min a $60^{\circ} \mathrm{C}$.

\section{Purificação das reações e sequenciamento.}

Foi utilizado o protocolo de precipitação com etanol/etilenodiaminotetracético (EDTA/Acetato de Sódio) para purificação da PCR. Foram adicionados 2,5 $\mu \mathrm{L}$ de EDTA (125 mM) em cada poço, seguido de spin. Então, foram adicionados $30 \mu \mathrm{L}$ de etanol 100\% em cada poço. Os poços foram selados com fita selante. A placa foi invertida cinco vezes para misturar e depois foram deixadas em local escuro por $20 \mathrm{~min}$. A placa foi centrifugada a 2700 xg (r.p.m. máximo) por $30 \mathrm{~min}$, a $4{ }^{\circ} \mathrm{C}$. A fita selante foi removida. Gentilmente o excesso de álcool sobrenadante foi removido por inversão. A placa foi invertida sobre papel absorvente e centrifugada a 180 xg por $10 \mathrm{~s}$ para remoção do álcool. Foram adicicionados $75 \mu \mathrm{L}$ de etanol 70\% em cada poço. A placa foi centrifugada a 2700 xg por $10 \mathrm{~min}$, a $4{ }^{\circ} \mathrm{C}$. Gentilmente o excesso de álcool sobrenadante foi retirado por inversão. A placa foi invertida sobre papel absorvente e centrifugada a $180 \mathrm{xg}$ por $10 \mathrm{~s}$ para remover o álcool. A placa foi levada a um evaporador a vácuo (Eppendorf dryer) por $5 \mathrm{~min}$. As amostras foram ressuspensas em $50 \mu \mathrm{L}$ de solução $0,05 \mathrm{mM}$ de EDTA. A placa foi cuidadosamente submetida a um vortex, seguido por um spin em uma centrífuga.

Em seguida as amostras foram sequenciadas em analisador automático de DNA ABI 3730 (Applied Biosystems). 


\section{Análises das sequências.}

Todas as sequências obtidas foram analisadas, alinhadas e editadas utilizando-se o programa Chromas Pro v1.5, 2003-2009 (Technelysium Pty). Através da análise visual dos eletroferogramas, as sequências de qualidade foram selecionadas e analisadas conjuntamente no programa BioEdit Sequence Alignment Editor v7.0.8.0, 1997-2007 (HALL, 1999), através da interface com o programa ClustalW multiple sequence alignment (HIGGINS et al., 1988). Terminais que contribuíram significativamente para eventuais incongruências foram excluídos das análises. As sequências obtidas foram alinhadas com o programa MAFFT versão 7 (Multiple alignment program for nucleotide sequence) (KATOH \& STANDLEY, 2013). O programa Mesquite (V3.01) (MADDISON \& MADDISON, 2014) foi utilizado para transformar os dados para o programa MrBayes 3.0 (RONQUIST \& HUELSENBECK, 2003), e para o programa PAUP 4.0 (SWOFFORD, 2002).

\section{Modelo de Kimura 2-parâmetros (Kimura-2P)}

Análise da probabilidade das substituições nucleotídicas

Utilizando-se o programa MEGA 6.06 (TAMURA et al., 2013), foram calculadas as frequências nucleotídicas, probabilidades de transições e transversões, com cálculos das taxas $K_{l}$ (transições/transversões) para purinas e $K_{2}$ (transversões/transições). Também foram calculados o número de sítios conservados, o número de sítios variáveis e o número de sítios filogeneticamente informativos.

\section{Cálculo das Distâncias Intraespecíficas e Interespecíficas}

Com o programa MEGA 6.06 (TAMURA et al., 2013), utilizando-se o modelo evolutivo Kimura 2 parâmetros (KIMURA, 1980), foram calculadas as distâncias intraespecíficas e interespecíficas das espécies analisadas. A distância intraespecífica foi obtida pela média aritmética das distâncias entre pares de indivíduos dentro de cada espécie. O número de indivíduos por espécie variou nas análises de cada marcador. A diversidade interespecífica foi obtida pela média aritmética das distâncias aos pares entre indivíduos de diferentes espécies. Dessa forma, as divergências interespecíficas foram obtidas pelo cálculo da média aritmética dos valores de distância de todos os 
possíveis pares de grupos. Através do programa MEGA 6.06 (TAMURA et al., 2013) foram geradas matrizes de distâncias para as diferentes espécies par a par. A partir dos valores das distâncias, gráficos de distribuição e frequência das variações intraespecíficas e interespecíficas foram construídos no Microsoft Office Excel para visualização dos resultados de todos os conjuntos de dados.

\section{Construção das árvores de Inferência Bayesiana (IB), Máxima Parcimônia (MP) e Máxima Verossimilhança (MV)}

As árvores foram construídas para os marcadores matk, $r b c L$, trnL, $p s b A$-trnH, ITS e PRK utilizando-se os métodos de Inferência Bayesiana (IB), Máxima Parcimônia (MP) e Máxima Verossimilhança (MV). As árvores de IB foram geradas no programa MrBayes 3.2.6 (RONQUIST \& HUELSENBECK, 2003) e visualisadas no programa Fig Tree v1.4.2 (RAMBAUT, 2014). As árvores de Máxima Parcimônia foram geradas no programa PAUP 4.0 (SWOFFORD, 2002) e visualisadas no programa Fig Tree v1.4.2 (RAMBAUT, 2014). As árvores de MV foram construídas utilizando-se o programa MEGA 6.06 (TAMURA et al., 2013), e o melhor modelo de evolução molecular, GTR = General Time Reversible, foi selecionado utilizando-se o programa jModelTest 2.1.9 (POSADA, 2008). O teste de confiança de suporte dos nós das árvores foi o bootstrap (FELSENSTEIN, 1985), com 1000 repetições nas árvores de MV e MP, e de probabilidade posterior nas árvores de IB.

\section{RESULTADOS}

\section{Amplificação e sequenciamento das amostras de Attalea.}

Primeiramente foram realizadas PCRs e reações de sequenciamento com quatro amostras de cada espécie, além das dez amostras de herbário. O primer RPB2 não apresentou amplificação com nenhuma amostra em todas as espécies. Os primers $m a t K, r b c L$, trnL, psbAtrnH, PRK e ITS funcionaram para várias amostras, e a partir destas sequências, foram geradas árvores Bayesianas. Estas árvores foram analisadas quanto à eficácia na diferenciação das espécies. As regiões $m a t K, r b c L$ trnL não apresentaram poder discriminatório eficiente. Em decorrência disso, não foram feitas novas amplificações com as demais amostras das sete espécies para estes três locos. As árvores geradas para os primers psbA-trnH, PRK e ITS 
apresentaram potencial de discriminação interespecífico, por esta razão, foram realizadas novas PCRs com o número total de amostras que variou entre 16 e 20 por espécie.

A taxa de sucesso das amplificações e sequenciamento das amostras de Attalea foi abaixo do esperado, mesmo após tentativas de otimização de protocolos, principalmente com os primers que apresentaram potencial para barcode. Foram realizadas três extrações de DNA, sendo testado um protocolo de sorbitol (RUSSEL et al., 2010; SOUZA et al., 2012). A extração com sorbitol não melhorou o resultado das amplificações. As reações de PCR e sequenciamento foram repetidas duas vezes para os marcadores $m a t K, r b c L$ e trnL e sete vezes para os marcadores $p s b A$-trnH, ITS, PRK e RPB2. Essas repeticões foram realizadas com diferentes amostras de diluição dos reagentes, com o objetivo de agregar o maior número amostral das espécies nas análises.

As amostras de Attalea teixeirana foram agregadas ao trabalho. Para isso, foram realizadas PCRs e reações de sequenciamento com 13 amostras e os seis locos que apresentaram amplificação anteriormente. Além disso, nestas reações foram acrescentadas duas amostras de A. speciosa e duas amostras de A. eichleri que foram coletadas juntamente com as amostras dos híbridos.

Poucas amostras foram agregadas nas árvores finais. A eficácia das amplificações foi calculada em porcentagem e está demonstrada na Figura 18. A quantidade de amostras das espécies de Attalea que obtiveram amplificações de alta qualidade foi insatisfatória. Em PCRs realizadas com os marcador nuclear ITS muitas vezes, ao examinar-se o gel de agarose, a amplificação foi tida como bem sucedida. No entanto, ao realizar-se o sequenciamento, observaramse sequências que, ao serem comparadas no GenBanK foram identificadas como DNA de fungos. 


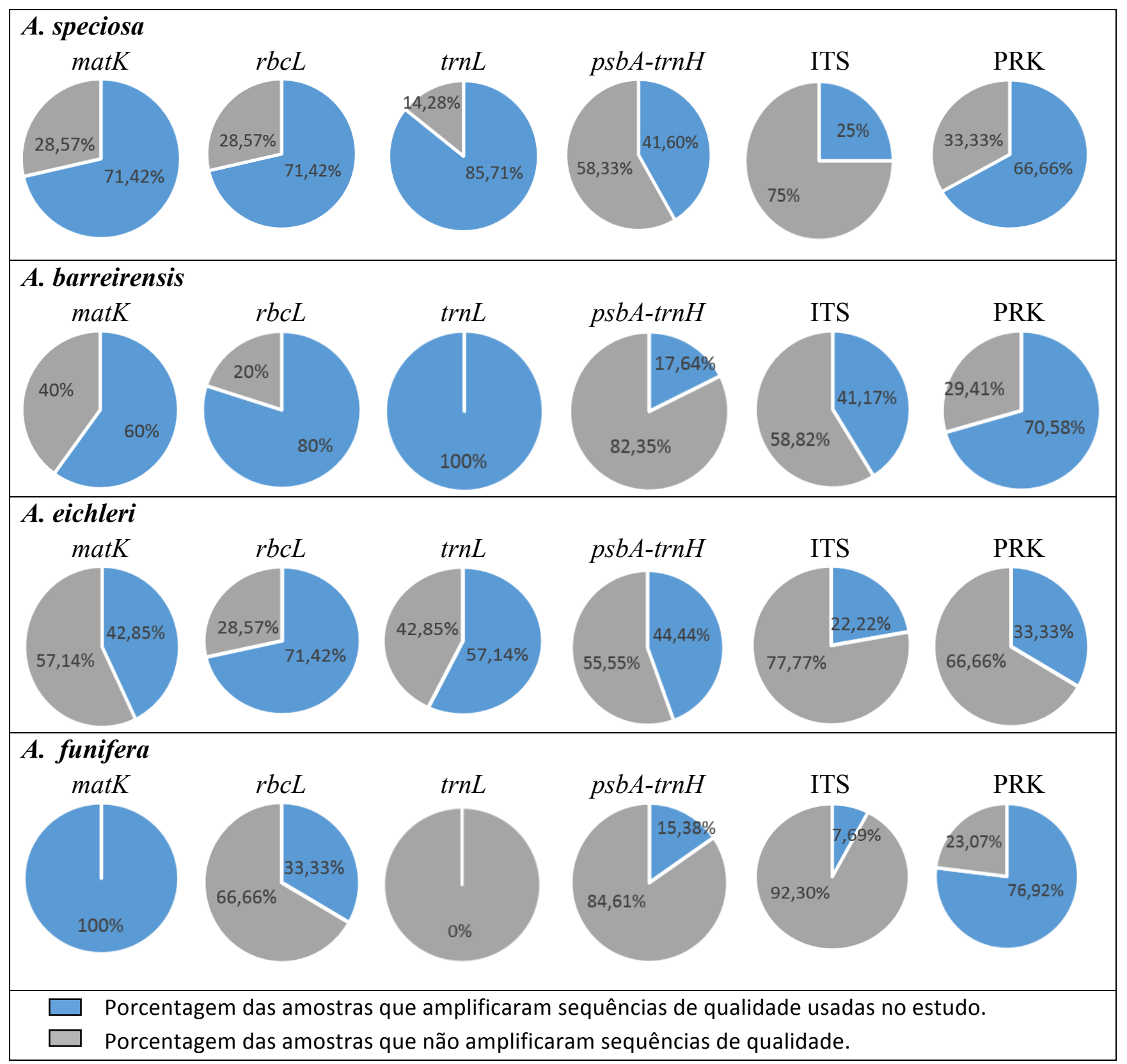

Figura 18. Eficácia da amplificação das sequências por marcador utilizado para as espécies $A$. speciosa, A. barreirensis, A. eichleri e A. funifera. 


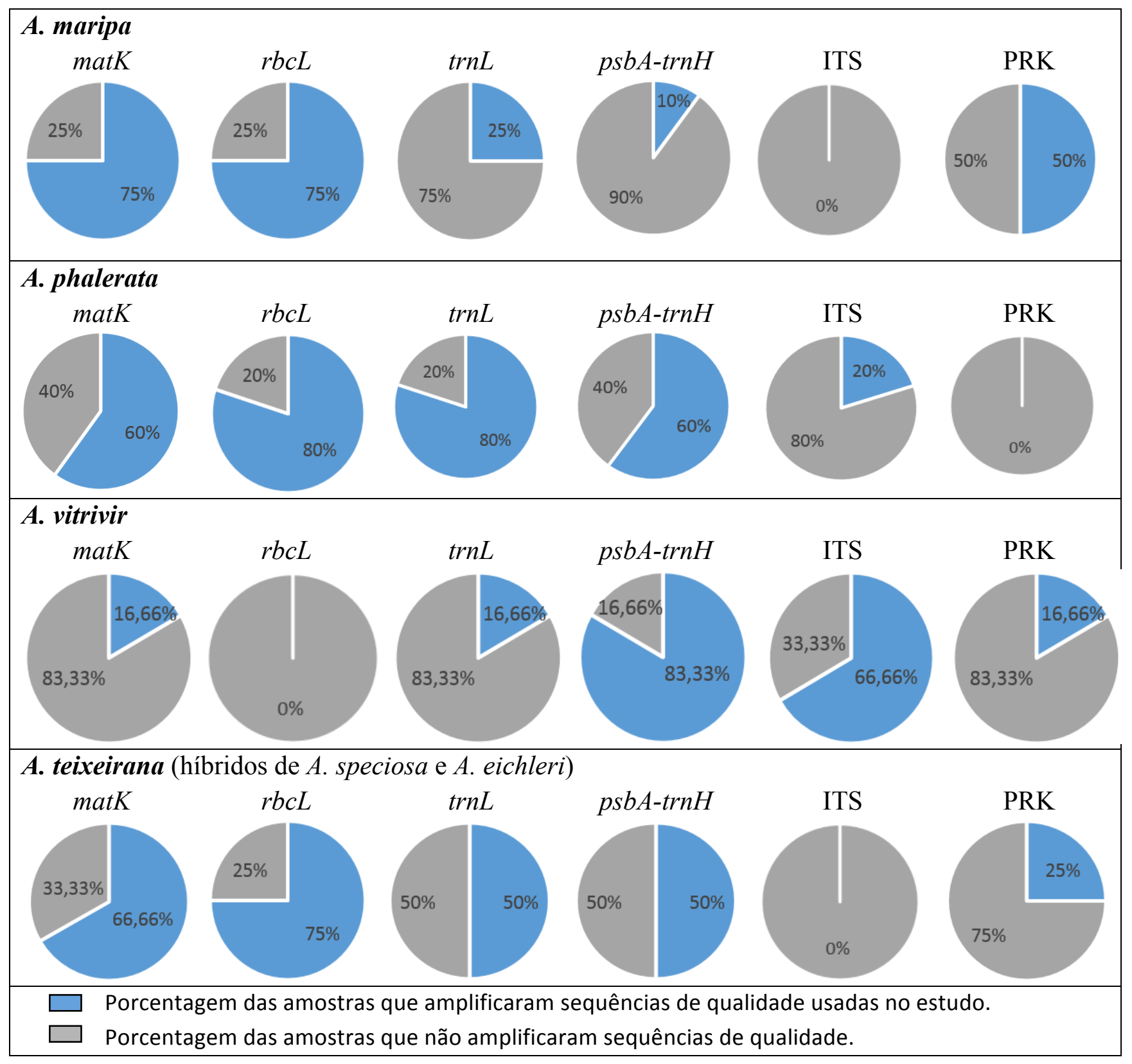

Figura 18 (continuação). Eficácia da amplificação das sequências por marcodor utilizado para as espécies A. maripa, A. phalerata, A. vitrivir e A. teixeirana.

As sequências geradas com todas as amostras analisadas para cada marcador utilizado podem ser observadas no anexo V (páginas 121-149). 


\section{Frequências nucleotídicas.}

As frequências nucleotídicas, por marcador barcode, estão relacionadas na Tabela 9. A quantidade de bases púricas, bases pirimídicas, transições, transversões, a razão das taxas de transições/transversões, a razão das taxas de transversões/transições com seus respectivos valores de viés, estão relacionados na Tabela 10. O número total de bases das sequências por marcador, de sítios conservados, de sítios variáveis e de sítios filogeneticamente informativos por marcador estão relacionados na Tabela 11. A probabilidade de substituições nucleotídicas em valores percentuais, calculadas para todas as amostras por loco de acordo com o modelo de substituição de Tamura-Nei (2004), indicando as taxas de transições e transversões estão indicados na Tabela 12.

Tabela 9. Porcentagem de bases das sequências analisadas por marcador utilizado. Cálculos realizados no programa MEGA 6.06.

\begin{tabular}{lcccc}
\hline & $\mathbf{A}$ & $\mathbf{T}$ & $\mathbf{C}$ & $\mathbf{G}$ \\
\hline matK & $35,85 \%$ & $29,56 \%$ & $16,28 \%$ & $18,31 \%$ \\
rbcL & $27,37 \%$ & $29,00 \%$ & $21,65 \%$ & $21,62 \%$ \\
trnL & $37,92 \%$ & $27,36 \%$ & $15,59 \%$ & $19,12 \%$ \\
psbA-trnH & $28,37 \%$ & $39,39 \%$ & $14,95 \%$ & $17,29 \%$ \\
ITS & $19,77 \%$ & $11,80 \%$ & $32,79 \%$ & $35,64 \%$ \\
PRK & $32,47 \%$ & $30,13 \%$ & $16,69 \%$ & $20,70 \%$ \\
\hline
\end{tabular}

Tabela 10. Porcentagem de bases púricas, bases pirimídicas, transições, transversões. Razão das taxas de transições/transversões, das taxas de transversões/transições por marcadores com seus respectivos valores de viés. Cálculos realizados no programa MEGA 6.06.

\begin{tabular}{lccccccc}
\hline & Purinas & Pirimidinas & Transições & Transversões & $\begin{array}{c}\boldsymbol{k}_{\boldsymbol{1}} \\
\text { purinas }\end{array}$ & $\begin{array}{c}\boldsymbol{k}_{\boldsymbol{2}} \\
\text { pirimidinas }\end{array}$ & Viés \\
\hline matK & $54,16 \%$ & $45,84 \%$ & $74,19 \%$ & $25,8 \%$ & 10,614 & 0 & 2,806 \\
rbcL & $48,99 \%$ & $50,65 \%$ & $20,42 \%$ & $79,58 \%$ & 0 & 1,013 & 0,254 \\
trnL & $57,04 \%$ & $42,95 \%$ & $75,96 \%$ & $24,04 \%$ & 4,69 & 8,495 & 2,867 \\
psb $\boldsymbol{A}$-trnH & $45,66 \%$ & $54,34 \%$ & $34,48 \%$ & $65,56 \%$ & 1,383 & 0,774 & 0,457 \\
ITS & $55,41 \%$ & $44,59 \%$ & $73,29 \%$ & $26,71 \%$ & 5,74 & 5,177 & 2,448 \\
PRK & $53,17 \%$ & $46,82 \%$ & $78,85 \%$ & $21,14 \%$ & 7,714 & 7,781 & 3,509 \\
\hline
\end{tabular}


Tabela 11. Número total de bases das sequências por marcador. Número total de sítios conservados, de sítios vaiáveis e de sítios filogeneticamente informativos por marcador. Cálculos realizados no programa MEGA 6.06.

\begin{tabular}{|c|c|c|c|c|}
\hline & $\begin{array}{c}\text { Total de } \\
\text { bases }\end{array}$ & $\begin{array}{c}\text { Sítios } \\
\text { conservados }\end{array}$ & $\begin{array}{c}\text { Sítios } \\
\text { variáveis }\end{array}$ & $\begin{array}{c}\text { Sítios filogeneticamente } \\
\text { informativos }\end{array}$ \\
\hline matK & 566 & 559 & 6 & 2 \\
\hline$r b c L$ & 490 & 481 & 5 & 0 \\
\hline $\operatorname{trn} L$ & 469 & 455 & 7 & 1 \\
\hline$p s b A-\operatorname{trn} H$ & 446 & 503 & 29 & 7 \\
\hline ITS & 340 & 246 & 65 & 27 \\
\hline PRK & 531 & 438 & 85 & 31 \\
\hline
\end{tabular}

Tabela 12. Probabilidade de substituições nucleotídicas, em valores percentuais, calculadas para todas as amostras, por loco, de acordo com o modelo de substituição de Tamura-Nei (2004). Valores em negrito indicam transições, em itálico transversões, cálculos realizados no programa MEGA 6.06.

\begin{tabular}{|c|c|c|c|c|c|}
\hline & & $\mathbf{A}$ & $T$ & $\mathrm{C}$ & G \\
\hline \multirow{4}{*}{ matK } & $\mathbf{A}$ & - & 3,81 & 2,1 & 25,08 \\
\hline & $\mathbf{T}$ & 4,63 & - & 0 & 2,36 \\
\hline & $\mathbf{C}$ & 4,63 & 0 & - & 2,36 \\
\hline & $\mathbf{G}$ & 49,11 & 3,81 & 2,1 & - \\
\hline \multirow{4}{*}{$r b c L$} & $\mathbf{A}$ & - & 11,54 & 8,61 & $\mathbf{0}$ \\
\hline & $\mathbf{T}$ & 11,03 & - & 8,73 & 8,61 \\
\hline & C & 11,03 & 11,69 & - & 8,61 \\
\hline & $\mathbf{G}$ & 0 & 11,54 & 8,61 & - \\
\hline \multirow{4}{*}{$\operatorname{trn} L$} & $\mathbf{A}$ & - & 3,29 & 1,87 & 10,77 \\
\hline & $\mathbf{T}$ & 4,56 & - & 15,91 & 2,3 \\
\hline & $\mathbf{C}$ & 4,56 & 27,92 & - & 2,3 \\
\hline & $\mathbf{G}$ & 21,36 & 3,29 & 1,87 & - \\
\hline \multirow{4}{*}{$p s b A-t r n H$} & $\mathbf{A}$ & - & 12,91 & 4,9 & 7,84 \\
\hline & $\mathbf{T}$ & 9,3 & - & 3,79 & 5,67 \\
\hline & $\mathbf{C}$ & 9,3 & 9,99 & - & 5,67 \\
\hline & $\mathbf{G}$ & 12,86 & 12,91 & 4,9 & - \\
\hline \multirow{4}{*}{ ITS } & $\mathbf{A}$ & - & 1,58 & 4,38 & 27,31 \\
\hline & $\mathbf{T}$ & 2,64 & - & 22,67 & 4,76 \\
\hline & C & 2,64 & 8,16 & - & 4,76 \\
\hline & $\mathbf{G}$ & 15,15 & 1,58 & 4,38 & - \\
\hline \multirow{4}{*}{ PRK } & $\mathbf{A}$ & - & 3,19 & 1,76 & 15,7 \\
\hline & $\mathbf{T}$ & 3,43 & - & 13,73 & 2,19 \\
\hline & $\mathrm{C}$ & 3,43 & 24,79 & - & 2,19 \\
\hline & $\mathbf{G}$ & 24,63 & 3,19 & 1,76 & - \\
\hline
\end{tabular}




\section{Cálculo das distâncias Intraespecíficas e Interespecíficas.}

As matrizes das distâncias genéticas K2P para os marcadores matK, $r b c L$, trnL, psbA-trnH, PRK e ITS podem ser visualizadas no Anexo III (páginas 96-109). Somente os marcadores psbAtrnH, ITS e PRK apresentaram média dos valores das distâncias interespecíficas diferentes de zero (Tabela 13). Nestes três marcadores, as médias interespecíficas encontradas foram maiores que as médias intraespecíficas. Apesar da média das distâncias intraespecíficas e interespecíficas do marcador $p s b A$-trnH terem sido próximas a zero, foram gerados para este marcador gráficos de distância, devido a ser o único marcador plastidial que mostrou a formação de clados nas árvores Bayesianas.

Tabela 13. Médias das distâncias par a par das amostras de Attalea e Cocos nucifera (outgroup).

\begin{tabular}{lccc}
\hline Intraespecífica & Interespecífica & $\begin{array}{c}\text { Com outro Gênero } \\
\text { (Cocos nucifera) }\end{array}$ \\
\hline $\boldsymbol{m a t K}$ & 0,000 & 0,000 & 0,01 \\
$\boldsymbol{r b c \boldsymbol { L }}$ & 0,000 & 0,000 & 0,00 \\
$\boldsymbol{t r n \boldsymbol { L }}$ & 0,000 & 0,000 & 0,00 \\
$\boldsymbol{p} \boldsymbol{s} \boldsymbol{b} \boldsymbol{A}$-trn $\boldsymbol{H}$ & 0,003 & 0,0035 & 0,02 \\
ITS & 0,003 & 0,068 & 0,22 \\
PRK & 0,003 & 0,020 & 0,06 \\
\hline
\end{tabular}

psbA-trnH

As estimativas de distâncias par a par entre as sequências de Attalea geradas para o marcador psbA-trnH está no Anexo III, Tabela 20 (Páginas 103-104). As distâncias genéticas médias intraespecíficas variaram de 0 a 0,006, e as distâncias genéticas médias interespecíficas variaram de 0 a 0,008 (Figura 19). As distâncias par a par intraespecíficas geradas com o marcador psbA-trnH para a espécie $A$. maripa não foi calculada devido a análise só apresentar um exemplar desta espécie. A distância K2P intraespecífica média foi de 0,003. A distância K2P interespecífica média foi de 0,0035. É possível observar que para as espécies $A$. eichleri e $A$ teixeirana, as médias das distâncias intraespecíficas foram maiores que a média das distâncias interespecíficas (Figura 20). 


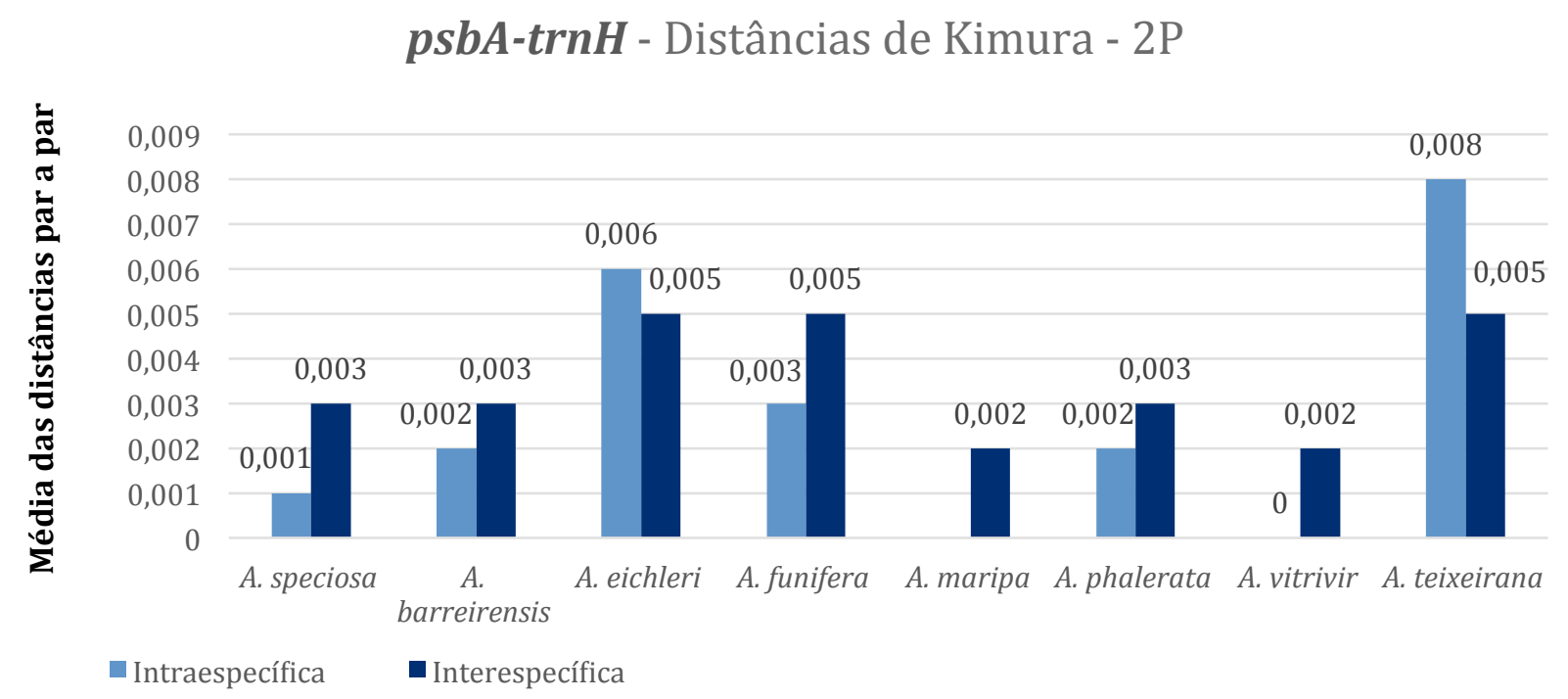

Figura 19. Distâncias médias K2P intraespecíficas e interespecíficas por espécie de Attalea para o marcador psbA-trnH.

$\mathrm{Na}$ distribuição das frequências das distâncias K2P para o marcador $p s b A$-trn $H$ observa-se uma sobreposição de valores nos intervalos 0,002 e 0,003 (Figura 20).

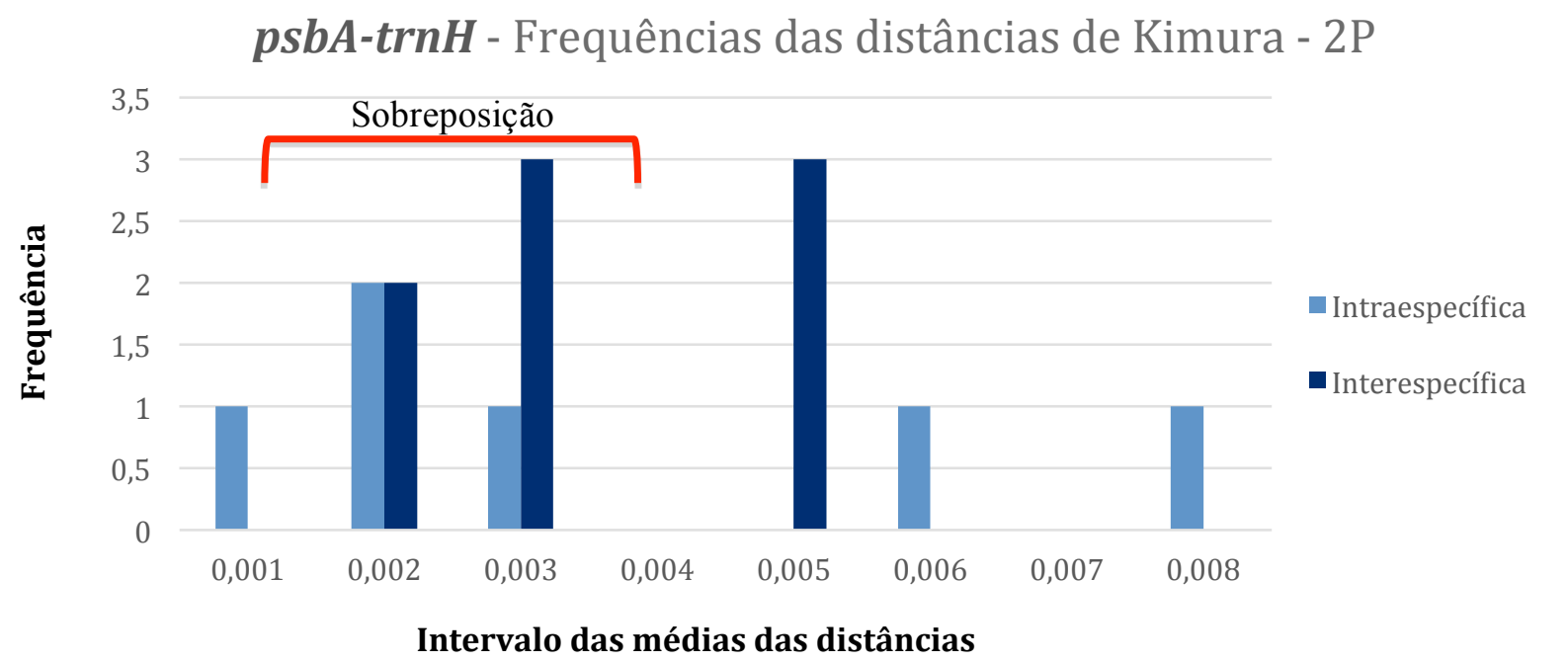

Figura 20. Distribuição das frequências das distâncias médias K2P intraespecíficas e interespecíficas para o marcador $p s b A$-trnH.

\section{PRK}

As estimativas de distâncias par a par entre as sequências de Attalea geradas para o marcador PRK, está no Anexo III, Tabela 22 (páginas 106-109). As distâncias genéticas médias intraespecíficas variaram de 0 a 0,003, e as distâncias genéticas médias interespecíficas variaram de 0 a 0,029 (Figura 21). As distâncias par a par intraespecíficas geradas com o marcador PRK para as espécies A. vitrivir, A. phalerata, A. allenii, A. cuatrecasana, A. cohune e A. oleifera não foram 
calculadas devido a análise só apresentar um exemplar de cada uma destas espécies. A distância K2P intraespecífica média foi de 0,003. A distância $2 \mathrm{P}$ interespecífica média foi de 0,02 . É possível observar que para todas as espécies, as médias das distâncias intraespecíficas foi menor que a média das distâncias interespecíficas (Figura 22).

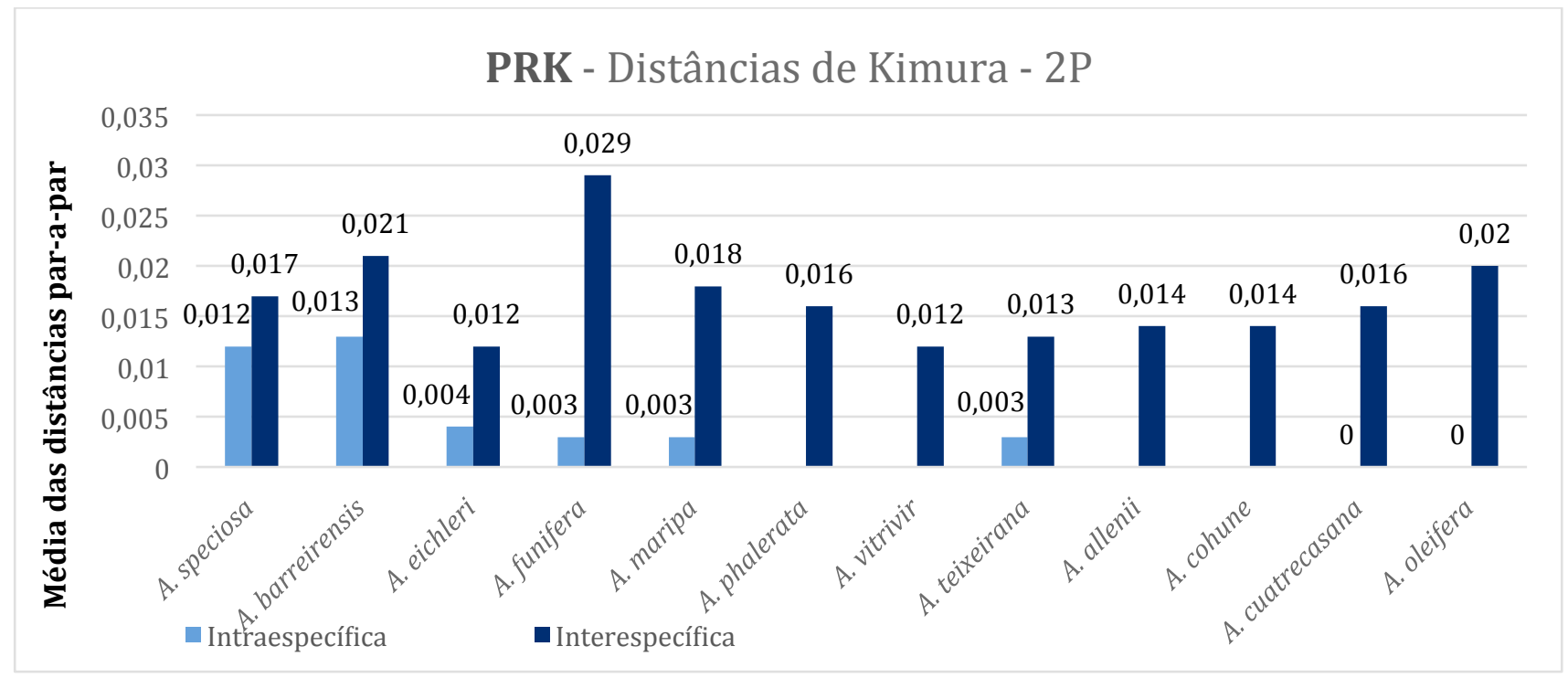

Figura 21. Distâncias médias K2P intraespecíficas e interespecíficas por espécies de Attalea para o marcador PRK.

Na distribuição das frequências das distâncias K2P para o marcador PRK observa-se uma sobreposição de valores no intervalo 0,01 a 0,014 (Figura 22).

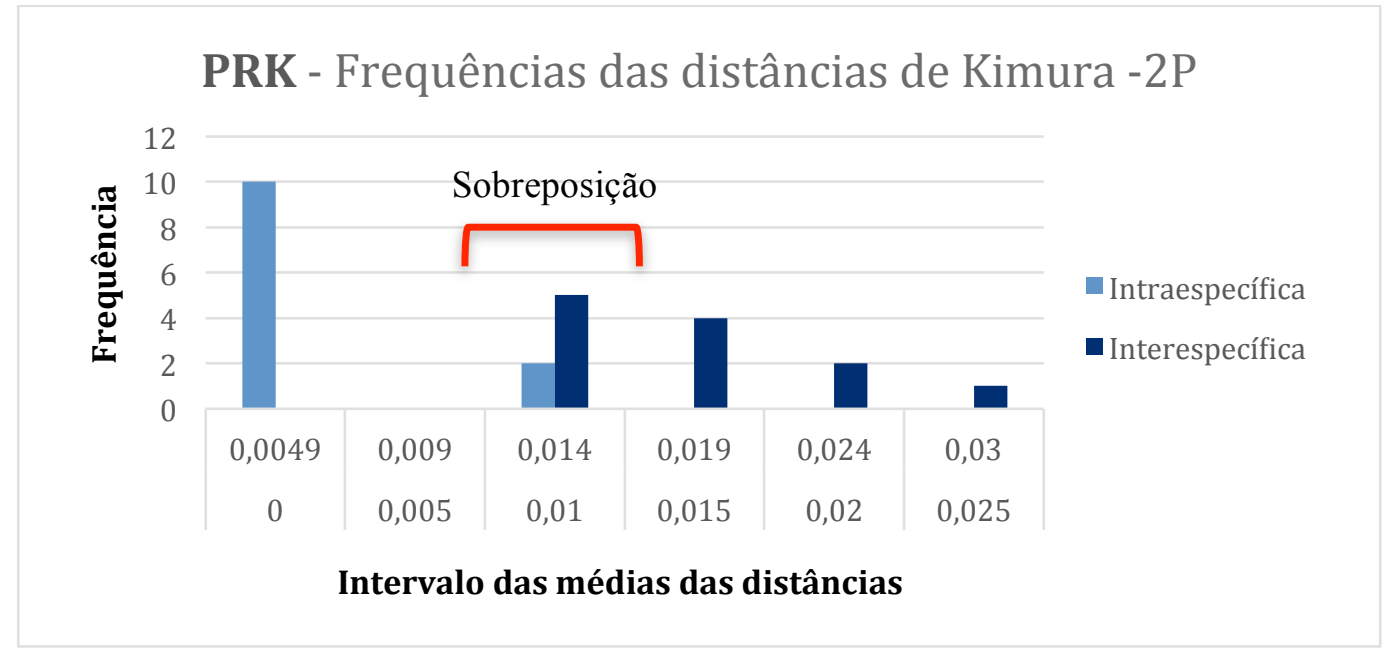

Figura 22. Distribuição das frequências das distâncias médias K2P intraespecíficas e interespecíficas para o marcador PRK.

\section{ITS}

As estimativas de distâncias par a par entre as sequências de Attalea geradas para o marcador ITS, está no Anexo III, Tabela 21 (página 105). As distâncias genéticas médias intraespecíficas 
variaram de 0 a 0,02 e as distâncias genéticas médias interespecíficas variaram de 0,05 a 0,1 (Figura 23). As distâncias intraespecíficas para as espécies A distância K2P intraespecífica média foi de 0,003. As distâncias par a par intraespecíficas geradas com o marcador ITS para as espécies $A$. funifera e A. phalerata não foram calculadas devido a análise só apresentar um exemplar de cada uma destas espécies. A distância K2P interespecífica média foi de 0,068. É possível observar que para todas as espécies, as médias das distâncias intraespecíficas foi menor que a média das distâncias interespecíficas (Figura 24).

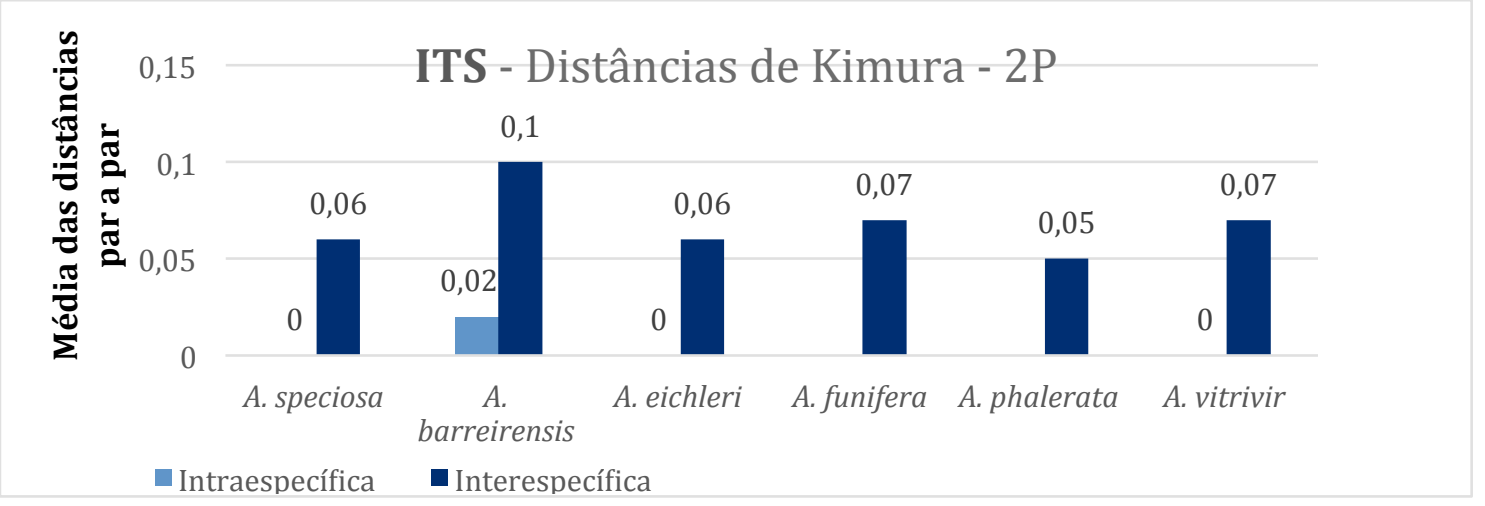

Figura 23. Distribuição das frequências das distâncias médias K2P intraespecíficas e interespecíficas para o marcador ITS.

$\mathrm{Na}$ distribuição das frequências das distâncias K2P para o marcador ITS observa-se um intervalo entre a maior frequência de valor médio de distâncias intraespecíficas e a menor frequência de valores médios de distâncias interespecíficas - intervalo de 0,02 a 0,05 (Figura 24). Este intervalo, chamado barcoding gap, apresentou-se somente no marcador ITS.

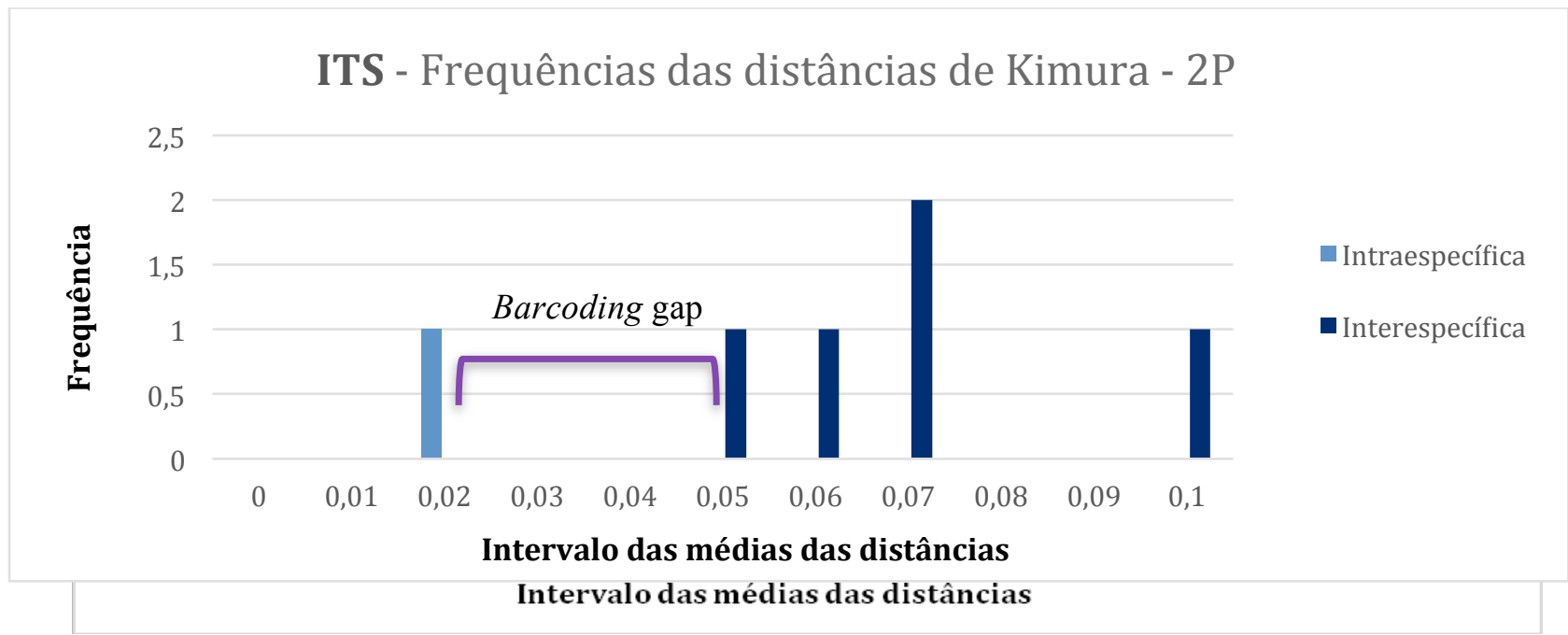

Figura 24. Distribuição das frequências das distâncias médias K2P intraespecíficas e interespecíficas para o marcador ITS. 


\section{Análise Bayesiana}

Nas árvores geradas por IB com os primers $m a t K, r b c L$ e $\operatorname{trn} L$ observa-se que as diferentes amostras de Attalea não foram agrupadas de forma a separar as espécies (Figuras 25, 26 e 27). A árvore de IB gerada a partir do marcador $p s b A-\operatorname{trn} H$ separou as espécies A. funifera e A. phalerata (colchete azul, Figura 28), no entanto, uma amostra de herbário de A. phalerata está localizada fora deste clado (colchete vermelho, Figura 28). As demais espécies avaliadas incluindo todos os híbridos agruparam-se.

$\mathrm{Na}$ árvore de IB gerada para o marcador ITS observa-se um clado significativo com todas as amostras de $A$. barreirensis e a única amostra de $A$. funifera que amplificou (colchete azul, Figura 29). As espécies A. speciosa, A. eichleri e $A$ vitrivir agruparam-se em um clado único (colchete vermelho, Figura 29). A única amostra de $A$. phalerata que amplificou foi separado em um clado significativo (colchete verde, Figura 29).

$\mathrm{Na}$ árvore de IB gerada para o marcador PRK observa-se uma separação muito clara de um clado com significância para a espécies A. funifera (colchete azul, Figura 30). Um clado signifivativo foi formado com todas as amostras de A. maripa (colchete vermelho, Figura 30). As amostras de $A$ barreirensis se dividiram em dois clados (colchete verde e amarelo, Figura 30). Observa-se também que o primeiro clado de $A$. barreirensis se agrupa, com baixa significância, com o clado de $A$. maripa (colchetes verde e vermelho, Figura 30). 


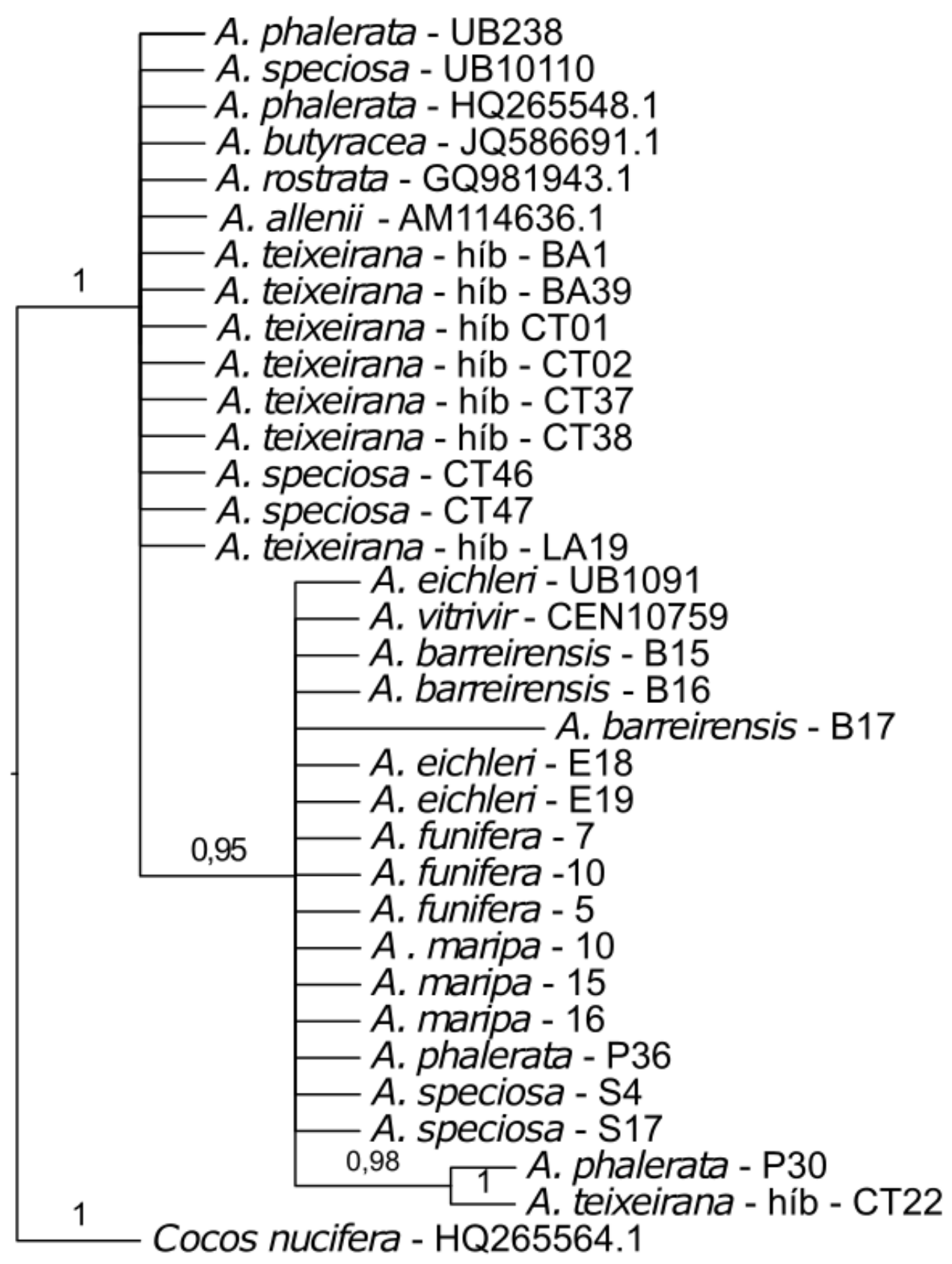

$\overline{0.04}$

Figura 25. Árvore filogenética de Inferência Bayesiana gerada a partir de sequências do gene matK, mostrando relações entre algumas espécies do gênero Attalea. Todos os valores de probabilidade posterior foram significativos (maiores que 90\%). Cocos nucifera (HQ265564.1) foi utilizado como outgroup. 


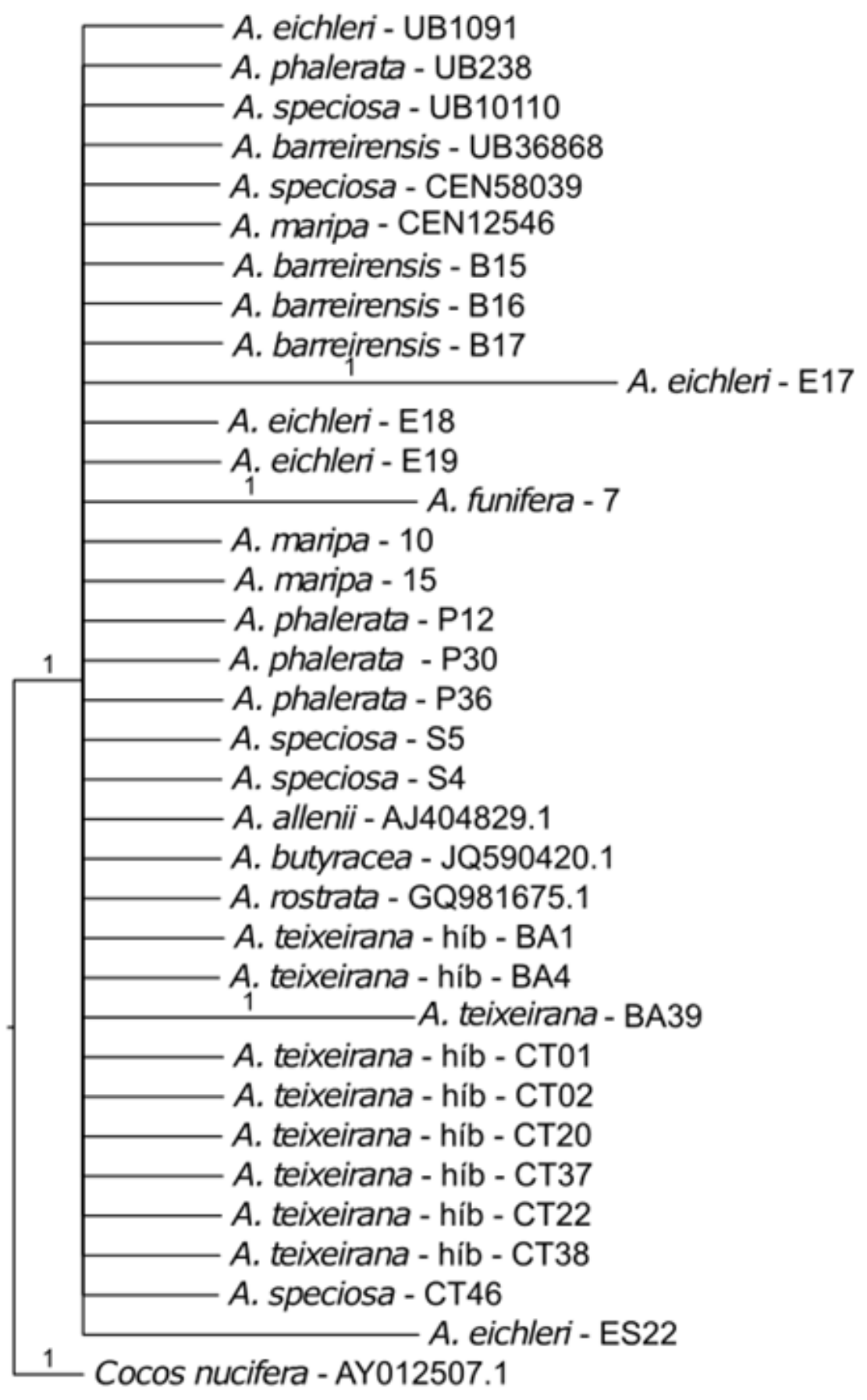

$\overline{0.03}$

Figura 26. Árvore filogenética de Inferência Bayesiana gerada a partir de sequências do gene $r b c L$, mostrando relações entre algumas espécies do gênero Attalea. Todos os valores de probabilidade posterior foram significativos (maiores que 90\%). Cocos nucifera (AY012507.1) foi utilizado como outgroup. 


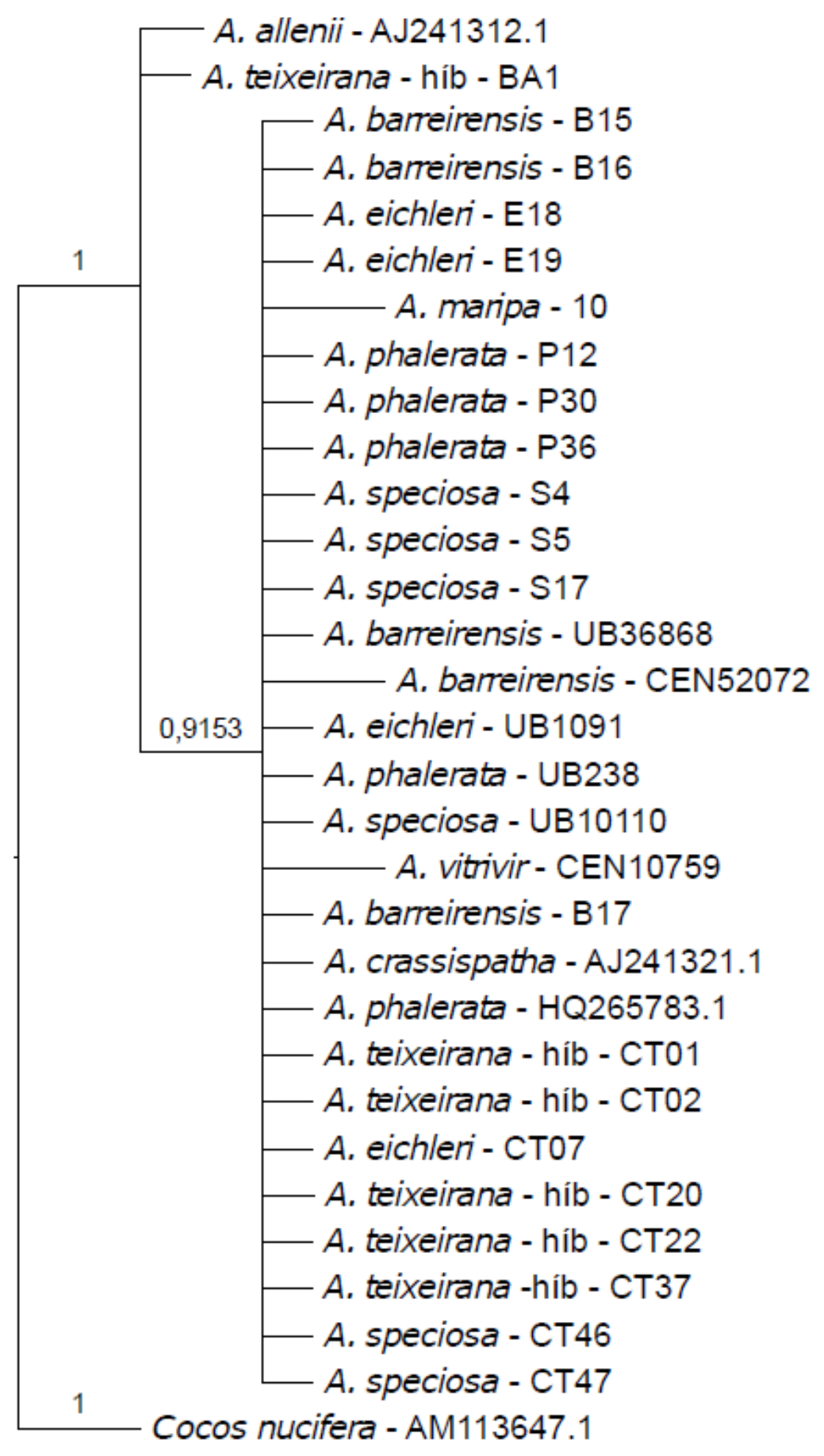

$\overline{0.05}$

Figura 27. Árvore filogenética de Inferência Bayesiana gerada a partir de sequências do gene $\operatorname{trn} L$, mostrando relações entre algumas espécies do gênero Attalea. Todos os valores de probabilidade posterior foram significativos (maiores que 90\%). Cocos nucifera (AM113647.1) foi utilizado como outgroup. 


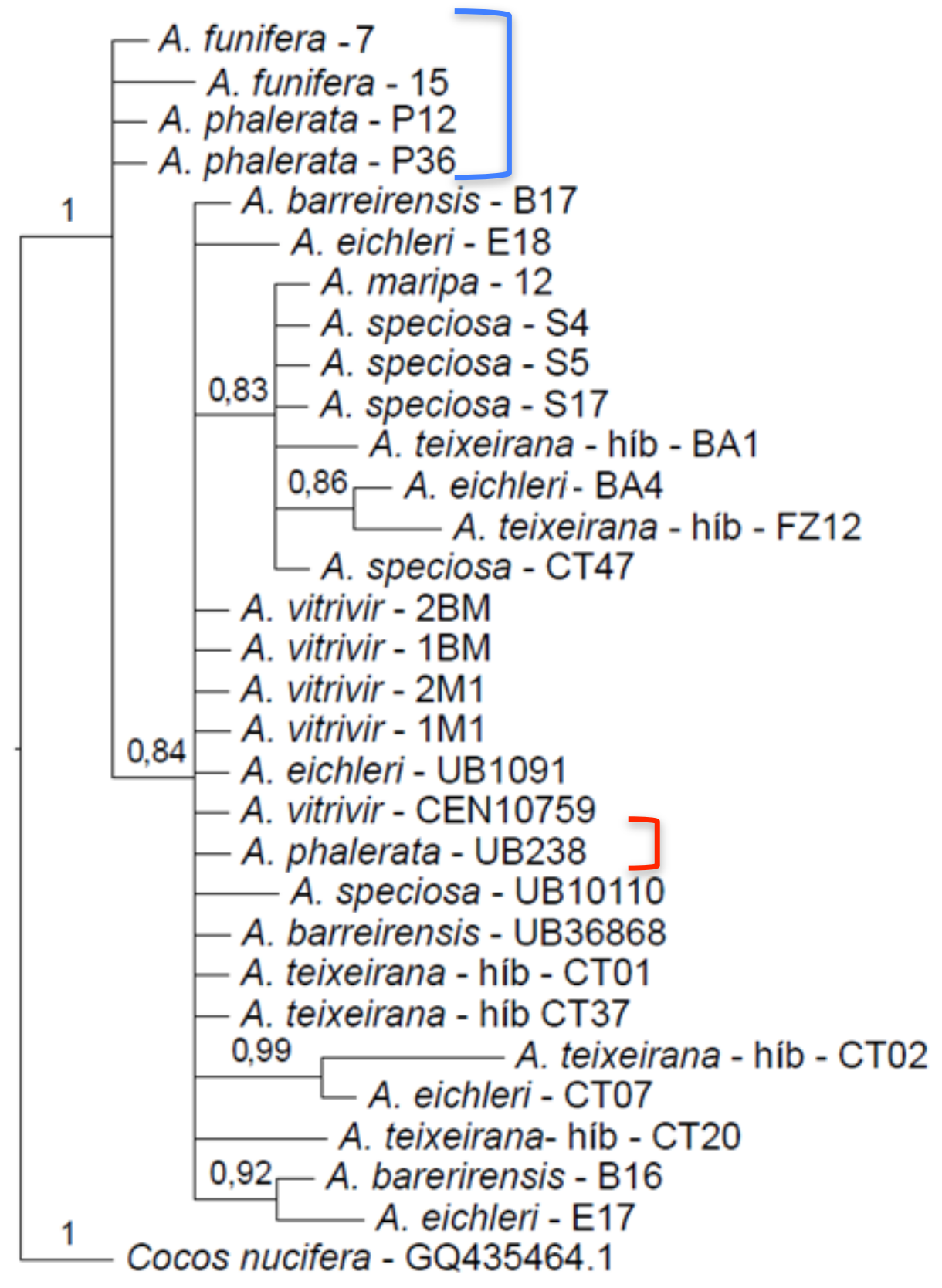

\subsection{6}

Figura 28. Árvore filogenética de Inferência Bayesiana gerada a partir de sequências do gene psbAtrnH, mostrando relações entre algumas espécies do gênero Attalea. Todos os valores de probabilidade posterior foram significativos (maiores que $90 \%$ ). O colchete azul destaca o clado com as espécies $A$. funifera e $A$. phalerata. O colchete vermelho destaca uma amostra de $A$. phalerata de herbário. Cocos nucifera (GQ435464.1) foi utilizado como outgroup. 


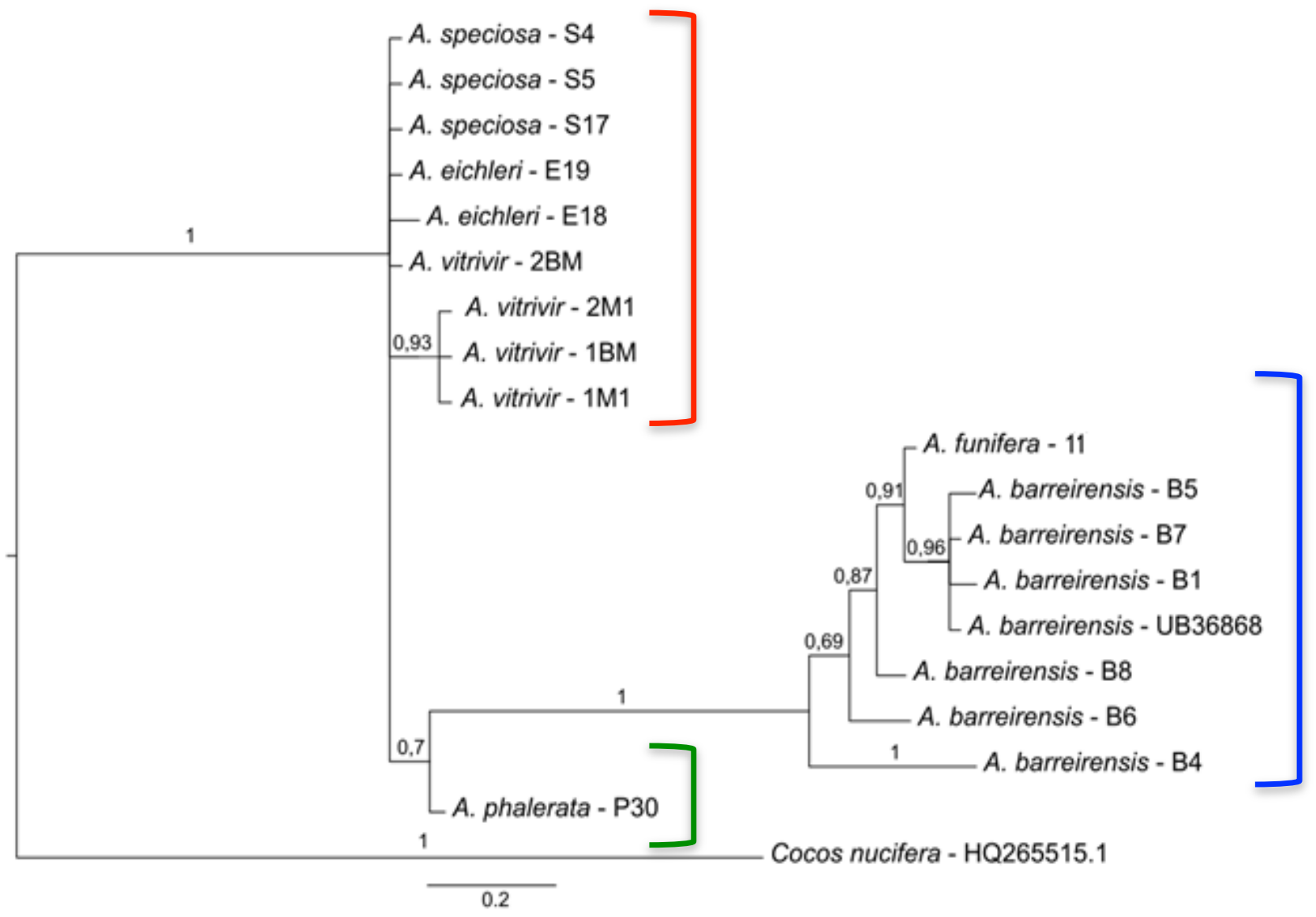

Figura 29. Árvore filogenética de Inferência Bayesiana gerada a partir de sequências do gene ITS, mostrando relações entre algumas espécies do gênero Attalea. A maioria dos valores da probabilidade posterior foram significativos (maiores que 90\%) O colchete vermelho destaca o clado com as espécies $A$. speciosa, A. eichleri e A. vitrivir. O colchete azul destaca o clado com as espécies A. funifera e $A$. barreirensis. O colchete verde destaca o clado com a espécie A. phalerata. Cocos nucifera (HQ265515.1) foi utilizado como outgroup. 


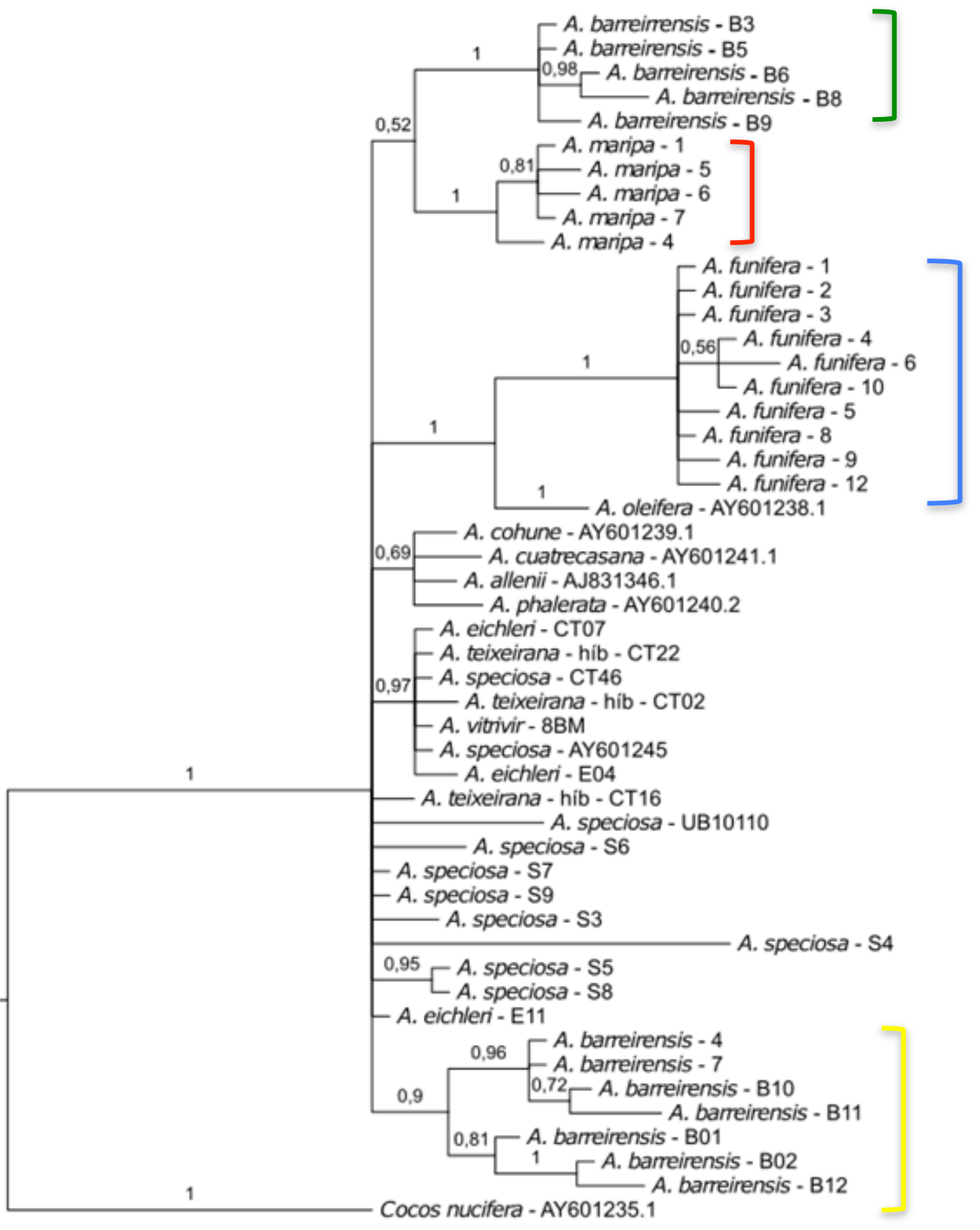

0.2

Figura 30. Árvore filogenética de Inferência Bayesiana gerada a partir de sequências do gene PRK, mostrando relações entre algumas espécies do gênero Attalea. A maioria dos valores da probabilidade posterior foram significativos (maiores que $90 \%$ ). O colchete vermelho destaca o clado com a espécie $A$. maripa. O colchete azul destaca o clado com a espécie $A$. funifera. Os colchetes verde e amarelo destacam os clados com a espécie $A$. barreirensis. Cocos nucifera (AY601235.1) foi utilizado como outgroup. 


\section{Análise por Máxima Parcimônia}

As árvores de MP não apresentaram agrupamentos com diferenças significativas das árvores de IB. As árvores geradas podem ser observadas no anexo IV (páginas 110-120). Estas árvores foram analisadas e geraram características conforme apresentado na tabela 14.

O marcador psbA-trnH apresentou uma região com grande presença de inserções e deleções, o que gerou um grande número de gaps na análise final (Anexo V, página 140). As amostras retiradas do GenBank, A. speciosa (KC924916. 1) e A. phalerata (KC924913. 1), apresentaram porção terminal de suas sequências justamente nesta região, como não é possível determinar quais são as bases que antecedem a porção terminal destas amostras, elas foram excluídas na construção das árvores. A matriz psbA-trnH alinhada mostrou-se rica em indels potencialmente informativos, os quais foram codificados e acrescentados à matriz de dados utilizando-se o programa Fastgap 1.2 (BORCHSENIUS, 2009). Foi gerada uma nova árvore para fins de comparação. Na árvore em que os indels foram codificados, apesar de terem sido formados novos clados, não ocorreram separações cladísticas importantes das espécies analisadas (Figura 31).

Tabela 14. Sumário das características das sequências e das estatísticas das árvores (análises de máxima parcimônia).

\begin{tabular}{|c|c|c|c|c|c|c|c|}
\hline & matK & $r b c L$ & trnL & $\begin{array}{l}p s b A \text {-trnH } \\
\text { (com gaps) }\end{array}$ & $\begin{array}{l}p s b A \text {-trnH } \\
\text { (sem gaps) }\end{array}$ & PRK & ITS \\
\hline \multicolumn{8}{|l|}{ Características das sequências } \\
\hline $\mathrm{N}^{\circ}$ de caracteres totais & 604 & 342 & 471 & 517 & 529 & 531 & 340 \\
\hline $\mathrm{N}^{\circ}$ de caracteres constantes & 598 & 195 & 464 & 501 & 499 & 446 & 275 \\
\hline Sítios variáveis e não informativos & 4 & 80 & 6 & 11 & 20 & 54 & 38 \\
\hline Sítios informativos por parcimônia & 2 & 67 & 1 & 5 & 10 & 31 & 27 \\
\hline \multicolumn{8}{|l|}{ Estatística das árvores } \\
\hline $\mathbf{N}^{\circ}$ de árvores mais parcimoniosas & 1 & 1 & 3 & 28 & 5000 & 16 & 1 \\
\hline Comprimento das árvores & 6 & 220 & 7 & 20 & 37 & 111 & 78 \\
\hline Índice de consistência (IC) & 1,0 & 0,82 & 1,0 & 0,90 & 0,86 & 0,81 & 0,94 \\
\hline Índice de Retenção (IR) & 1,0 & 0,85 & 1,0 & 0,88 & 0,87 & 0,89 & 0,97 \\
\hline Índice de Retenção Rescalonado (RC) & 1,0 & 0,70 & 1,0 & 0,79 & 0,75 & 0,73 & 0,92 \\
\hline
\end{tabular}


Análise com MP com psbA-trnH:

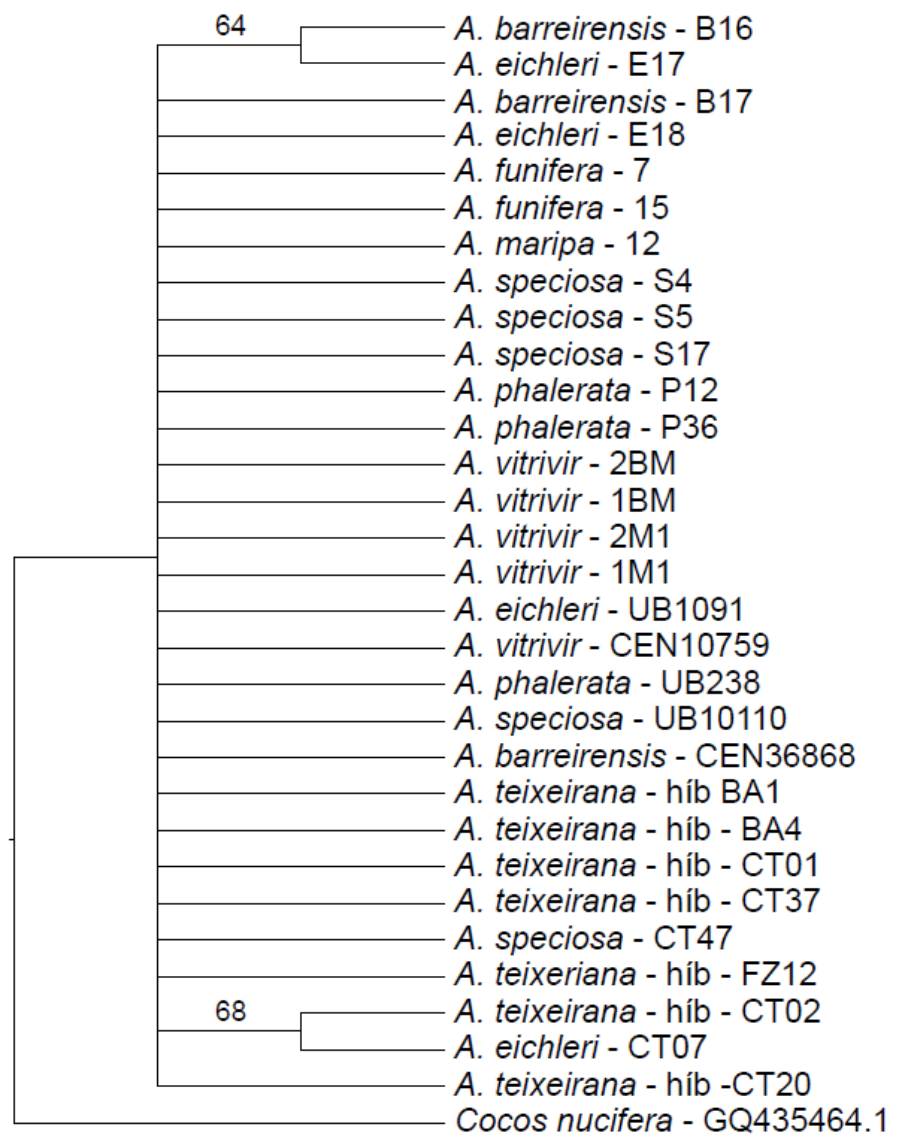

$\overline{0.3}$

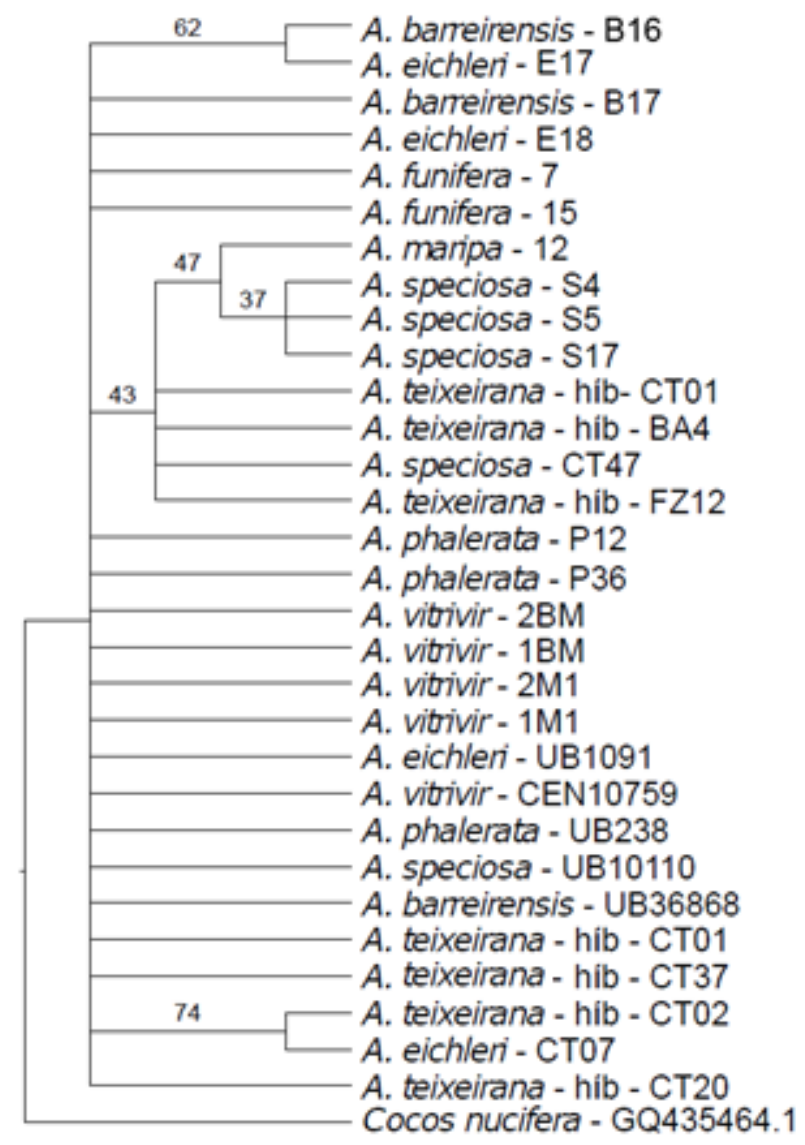

$\overline{0.5}$

Figura 31. Árvores filogenéticas de MP geradas a partir de sequências do marcador $p s b A-t r n H$. A árvore da esquerda foi gerada sem considerar os gaps, enquanto que a árvore da direita foi gerada com a atribuição numérica dos gaps. Cocos nucifera (GQ 435464.1) foi utilizado como outgroup. O valor indicado acimo dos ramos indica a porcentagem de bootstrap. 


\section{Máxima Verossimilhança}

As árvores de MV não apresentaram informações significativas diferentes das árvores de IB e de MP. As árvores geradas podem ser observadas no Anexo IV (páginas 115-120).

\section{DISCUSSÃO}

Em vista da escassez de estudos de barcode para o gênero Attalea, este trabalho representa um esforço pioneiro no sentido de ampliar o banco de dados de sequências nucleotídicas potencialmente informativas para auxiliar análises de identificação taxonômica nestas espécies. As análises filogenéticas moleculares levaram a mudanças dramáticas na classificação das palmeiras, como mostra a comparação entre a primeira e a segunda edições do Genera palmarum (UHL \& DRANSFIELD, 1987; DRANSFIELD et al., 2008). Elucidar regiões barcode potencialmente úteis para o gênero Attalea podem ajudar a fomentar a classificação taxonômica atual ou propor ajustes na já existente.

\section{Amplificação e sequenciamento das amostras de Attalea.}

O uso de sequências de DNA para a inferência da identidade taxonômica por barcode de um grupo de espécies necessita de uma ampla amostragem de sequências. A baixa quantidade de amostras com qualidade satisfatória ocorre devido a problemas na etapa de extração de DNA ou na etapa de sequenciamento, ou ainda devido à baixa qualidade da amostra utilizada.

A extração de DNA das amostras deste estudo foi repetida três vezes, sendo uma delas feita com o protocolo de sorbitol, portanto é mais provável que a baixa qualidade das amostras foliares tenha sido a causa do baixo rendimento.

O DNA extraído pode ser utilizado para a amplificação tanto de fragmentos, como para sequenciamento. Também é possível observar que a porcentagem de amplificação das amostras com os marcadores plastidiais foi expressivamente maior do que a amplificação observada com os marcadores nucleares (Figura 18). Como os marcadores barcode nucleares podem ser utilizados com praticamente todos os seres vivos, nas análises com marcador ITS observou-se a contaminação de muitas amostras com fungos.

Uma dificuldade que a amplificação com os marcadores pode ter apresentado se deve ao fato do DNA estar degradado. Outro problema se deve ao isolamento de polissacarídeos, fenóis e 
compostos secundários no isolamento e purificação de DNA vegetal, podendo danificar o DNA e inibir a ação da enzima Taq polimerase (MOLINARI \& CROCHEMORE, 2001). Esses compostos ligam-se ao DNA após a lise das células e muitas vezes não podem ser removidos por procedimentos convencionais de extração (MALIYAKAL, 1992).

Uma das premissas da metodologia barcode é a rápida identificação das espécies. Para que isso aconteça, é necessária a rápida extração e amplificação de DNA para conseguinte análise das sequências. A dificuldade observada neste trabalho para a amplificação das amostras de diferentes espécies de Attalea se mostra um empecilho para a aplicação da técnica barcode neste gênero. Outros protocolos de extração de DNA necessitam ser testados a fim de solucionar este problema. Danner e colaboradores (2011) testaram diferentes protocolos de extração de DNA de jabuticabeiras comparando diferentes tecidos vegetais. Os resultados demonstraram degradação e contaminação na extração em que se utilizaram folhas maceradas diretamente com tampão CTAB (2\%), e bons resultados com os demais tecidos vegetais. São necessários novos testes para otimizar a extração do DNA de espécies de Attalea para a utilização da técnica barcode.

\section{Distâncias Intraespecíficas e Interespecíficas (Kimura 2P).}

A caracterização dos intervalos de variação intraespecífica e interespecífica apresentaram-se como zero para os marcadores matk, $r b c L$ e trnL, muito próximas de zero para o marcador $p s b A$ trnH. Para os marcadores ITS e PRK as distâncias intraespecíficas foram menores do que as distâncias interespecíficas. Limiares para diferenciação entre distâncias intraespecíficas e interespecíficas e de matrizes de distância são utilizadas na construção de fenogramas (HEBERT et al., 2003). Hebert e colaboradores (2003) sugerem o uso de um limiar de 3\% para a distinção de espécies, enquanto Hebert e colaboradores (2004) defendem a utilização de estimativas grupoespecíficas obtidas pela multiplicação da distância média intraespecífica por 10. Alguns autores já haviam levantado o problema de utilizar um único valor de distância para identificação de espécies, principalmente daquelas proximamente relacionadas (MEYER \& PAULAY 2005; RUBINOFF, 2006). Assim, foi sugerido que um valor universal para delimitar os táxons não deve ser considerado como um critério objetivo para estabelecer o limite entre as espécies (DeSALLE et al., 2005).

Considerando-se as distâncias intraespecíficas e interespecíficas, os locos PRK e ITS apresentaram um menor nível de divergência genética dentro das espécies do que entre as espécies de Attalea analisadas (Figuras 20 e 22). De acordo com Meyer e Paulay (2005) este é um pré-requisito para que um marcador possa ser utilizado como barcode. Somente o marcador ITS apresentou barcode gap, intervalo que separa as frequências entre as variações intraespecíficas e 
interespecíficas. Meier e colaboradores (2006) concluíram que a utilização da distância média interespecífica superestima o barcode gap e pode conduzir a identificações errôneas, e sugeriram que a utilização da distância mínima interespecífica produz identificações mais precisas. O marcador PRK apresentou sobreposição das distâncias genéticas intraespecíficas e interespecíficas, o que não é desejável. Sobreposição na distribuição das distâncias genéticas entre os indivíduos de uma mesma espécie e indivíduos de espécies de um mesmo gênero podem ser originários de profundas divergências intraespecíficas, ou baixas divergências entre espécies irmãs (HUBERT et al., 2008). No entanto, os dados sugerem que mesmo sem um barcode gap, o marcador PRK foi eficiente na separação de algumas espécies. A caracterização dos intervalos de variação intraespecífica e interespecífica dos marcadores ITS e PRK resultaram em distribuições distintas, sugerindo grande potencial para auxiliar na resolução de conflitos taxonômicos, apesar de ser necessário ampliar esta caracterização para um maior número de amostras e número de espécies, além de validar o intervalo de variação intraespecífica e interespecífica para este gênero.

\section{Árvores de barcode com os métodos de IB, MP e MV}

Nas árvores geradas por IB, MP e MV com os primers $m a t K, r b c L$ e $t r n L$ observa-se que as diferentes amostras de Attalea não foram agrupadas de forma a separar espécies.

A árvore gerada a partir do marcador $p s b A-t r n H$ separou as espécies A. funifera $e A$. phalerata em um clado com significância, apesar de uma amostra de herbário de $A$. phalerata se apresentar fora deste clado, o que pode significar uma identificação errônea do acesso ou a baixa confiabilidade na identificação desta espécie para este marcador.

As regiões PRK e ITS apresentaram cladogramas com melhor discriminação entre as seis regiões barcode testadas. Para o marcador PRK, as espécies A. funifera, A. barreirensis e A. maripa separaram-se em clados, porém as amostras de $A$. barreirensis dividiram-se em dois grupos distintos. Considerando-se que todas as amostras de A. barreirensis foram coletadas dentro da mesma população (pop. 21, localidade: São Raimundo das Mangabeiras, MA), sugere-se que esta população represente um complexo de espécies crípticas (SILVA-BRANDÃO et al., 2009), que são definidas como duas ou mais espécies morfologicamente indistinguíveis, reprodutivamente isoladas e classificadas como uma única espécie nominal (GOODMAN et al., 2009). Portanto, novas análises necessitam ser feitas dentro desta população, com novas coletas e outros marcadores para um melhor diagnóstico deste resultado.

O marcador ITS apresentou boa separação entre as espécies - dois grupos, um que agregou as amostras de $A$. barreirensis com $A$. funifera e outro em que se agruparam as amostras de $A$. speciosa, 
A.eichleri e A.vitrivir. $\mathrm{O}$ fato de as espécies A.vitrivir e A. speciosa estarem no mesmo clado corroboram com Pintaud e calaboradores (2008) que, em sua revisão, definiram o complexo Attalea speciosa, no qual as espécies $A$. brejinhoensis, A. speciosa, A. spectabilis, A. vitrivir estão agrupadas.

As espécies $A$. eichleri., A. speciosa e $A$. vitrivir tenderam a agrupar-se em todos os marcadores analisados. As espécies A. funifera e A. maripa apresentaram boa resolução com o marcador PRK.

As palmeiras são bem conhecidas pela alta variabilidade das taxas de evolução do DNA plastidial (BAKER et al., 1999; ASMUSSEN et al., 2000; BAKER et al., 2000; DRANSFIELD et al., 2008). No entanto, os marcadores plastidiais apresentaram menos dados filogeneticamente informativos do que os dados dos marcadores nucleares, como demonstrado pela comparação das estatísticas das análises dos nucleotídios (Tabela 9) associadas com as distribuições das espécies nas árvore de IB, MP e MV ( Figuras de 25-42). Isso pode ser explicado porque, ao contrário do DNA plastidial, o DNA nuclear tem origem biparental, o que aumenta o poder de separação de espécies dos marcadores na região do ITS, como demonstrado por Hollingsworth (2011).

As amostras de A. teixeirana são híbridos de A. speciosa e A. eichleri. Como os plastídios são herdados pela mãe, se os marcadores tivessem apresentado discriminação cladística, seria possível distinguir quais das duas espécies de origem representaria a mãe de cada híbrido. No entanto, como estes marcadores não apresentaram resolução sequer para separar estas duas espécies parentais, não foi possível realizar este tipo de análise.

São ainda necessários mais testes com mais amostras para comprovar a distribuição cladística observada. Uma combinação de todos os marcadores é necessária para uma melhor visualização do conjunto de dados deste trabalho, porém esta junção não foi possível devido a dificuldade das mesmas amostras amplificarem para todos os marcadores analisados. 


\section{CONCLUSÕES}

Os relacionamentos entre as espécies estudadas do gênero Attalea ainda não estão claros. O uso de marcadores barcode em espécies do gênero Attalea necessita ser aprimorado.

Para o uso eficiente do uso da tecnologia barcode, é necessário o estabelecimento de protocolos de extração de DNA, PCR e sequenciamento eficientes que maximizem o aproveitamento e minimizem a contaminação das espécies de Attalea.

Os marcadores $r b c L$, $t r n L$ e matK não apresentaram resolução suficiente para a discriminação das espécies. Os marcadores psbA-trnH, ITS e PRK apresentaram resultados potencialmente satisfatórios para serem usados como regiões barcode para espécies de Attalea.

São necessárias novas análises com maior amostragem para ratificar a eficácia dos marcadores $p s b A$-trnH, ITS e PRK para as espécies mencionadas. Deve ser realizada a busca de outros marcadores que juntamente com os já elucidados sejam suficientes para distinguir todas as espécies dentro do gênero Attalea e auxiliar na identificação e classificação taxonômica destas espécies. 


\section{REFERÊNCIAS BIBLIOGRÁFICA}

ALBERT, V. A. et al. Parsimony, phylogeny, and genomics. Oxford University Press, 2005.

ALMEIDA, A. W. B. Quebradeiras de Coco Babaçu: identidade e mobilização. São Luís: III Encontro Estadual das Quebradeiras de Coco babaçu. 1995.

ALVARADO, G.; JÁUREGUI, D. Anatomía del raquis y la lámina foliar de Attalea butyracea (Mutis ex L.f) Wess. Boer y Attalea marypa (Aubl.) Mart.(Arecaceae, Arecoideae). Pittieria, v. 35, p. 71-83, 2011.

ANDERSON, A. B.; BALICK, M. J. Taxonomy of the Babassu complex (Orbignya spp.: Palmae). Systematic Botany, p. 32-50, 1988.

ANDERSON, A. B.; MAY, P. H.; BALICK, M. J. The subsidy from nature: Palm forests, peasantry, and development on an Amazon frontier. Columbia University Press, 230p. 1991.

ANDERSON, A. B.; BALICK, M. J. Taxonomy of the Babassu complex (Orbignya spp.: Palmae). Systematic Botany, p. 32-50, 1988.

ARAÚJO, M. G. P.; LEITÃO, A. M.; MENDONÇA, M. S. Morfologia do fruto e da semente de Inajá (Attalea maripa (Aubl.) Mart.) - Palmae. Revista Brasileira de Sementes, v. 22, n. 2, p. 31-38, 2000 .

ARAÚJO, E. C. E. Estado da arte e potencial do babaçu para a agroenergia. In: CONGRESSO BRASILEIRO DE PLANTAS OLEAGINOSAS, ÓLEOS, GORDURAS E BIODIESEL, 5.; CLÍNICA TECNOLÓGICA EM BIODIESEL, 2,. Lavras. Biodiesel: tecnologia limpa. Anais... Lavras: UFLA, 12p. 2008.

ASMUSSEN, C. B.; BAKER, W. J.; DRANSFIELD, J. Phylogeny of the palm family (Arecaceae) based on rps16 intron and trnL-trnF plastid DNA sequences. Monocots: systematics and evolution. Collingwood, Australia: CSIRO, p. 525-537, 2000.

AVRAHAM, S. et al. Structural and functional studies of the intracellular tyrosine kinase MATK gene and its translated product. Journal of Biological Chemistry, v. 270, n. 4, p. 1833-1842, 1995.

AZEREDO, A. M. L. O Código de barras da vida baseado no DNA "Barcoding of Life": considerações e perspectivas. Centro de Gestão e Estudos Estratégicos. SP, CBMEG UNICAMP, 2005 .

BAKER, W. J. et al. A phylogenetic study of the palm family (Palmae) based on chloroplast DNA sequences from the trnL-trnF region. Plant Systematics and Evolution, v. 219, n. 1-2, p. 111-126, 1999.

BAKER, W. J.; HEDDERSON, T. A.; DRANSFIELD, J. Molecular phylogenetics of subfamily Calamoideae (Palmae) based on nrDNA ITS and cpDNA rps16 intron sequence data. Molecular phylogenetics and evolution, v. 14, n. 2, p. 195-217, 2000.

BAKER, W. J.; DRANSFIELD, J. Beyond Genera Palmarum: progress and prospects in palm systematics. Botanical Journal of the Linnean Society, 2016. 
BALICK, M. J. Systematics and economic botany of the Oenocarpus-Jessenia (Palmae) complex. New York Botanical Garden, New York (EUA), Advances in Economic Botany. 3:1140.1986.

BALICK, M. J.; PINHEIRO, C. Babaçu Orbignya phalerata. In: CLAY, Jason W.; PAULO DE TARSO, B. Sampaio; CLEMENT, Charles R.. Biodiversidade amazônica: exemplos e estratégias de utilização. Manaus, Instituto Nacional de Pesquisa da Amazônia, SEBRAE. p. 255-263. 2000.

BARBOSA RODRIGUES, J. Palmae Mattogrossenses novae vel minus cognitae. Rio de Janeiro, p. $1-88,1898$.

BESPAlHOK, J. C.; GUERRA, E. P.; OLIVEIRA, R. Melhoramento de Plantas. Disponível em: www.bespa.agrarias.ufpr.br/conteudo (2007). Acesso em novembro de 2014.

BORCHSENIUS, F. FastGap 1.2. Department of Biological Sciences, University of Aarhus, Aarhus, Denmark, 2009.

BRANDÃO, M.; LACA-BUENDIA, J. P.; MACEDO, J. F. Árvores nativas e exóticas do Estado de Minas Gerais. Belo Horizonte: Empressa de Pesquisa Agropecuária de Minas Gerais 528p. Por Geog, v. 4, 2002.

CARRAZZA, L. R. et al. Manual tecnológico de aproveitamento integral do fruto e da folha do Babaçu. $2^{a}$ Ed. Brasília: Instituto Sociedade, População e Natureza. p.62. 2012.

CARVALHO, D.C. de et al. Identificação molecular de peixes: o caso do Surubim (Pseudoplatystoma spp.). Rev Bras Reprod Anim, v. 32, n. 5, 2008.

CAVALLARI, M.M. et al. What is the name of the babassu? A note on the confusing use of scientific names for this important palm tree. Rodriguésia 67(2): 533-538, 2016.

CHINA PLANT BOL GROUP. A DNA barcode for land plants. Proceedings of the National Academy of Sciences, v. 106, n. 31, p. 12794-12797, 2009.

CHINA PLANT BOL GROUP. Comparative analysis of a large dataset indicates that internal transcribed spacer (ITS) should be incorporated into the core barcode for seed plants. Proceedings of the National Academy of Sciences, v. 108, n. 49, p. 19641-19646, 2011.

CHOO, J. et al. Characterization of 14 microsatellite loci in a tropical palm, Attalea phalerata (Arecaceae). American journal of botany, v. 97, n. 11, p. e105-e106, 2010.

COELHO, A. S. G.. BOOD: avaliação de dendrogramas baseados em estimativas de distâncias/similaridades genéticas através do procedimento de bootstrap. Goiânia: UFG, v. 1, 2000.

COELHO, S. T. et al. Panorama do potencial de biomassa no Brasil. Agência Nacional de Energia Elétrica, MCT, Brasília, 75p. 2002.

COLLARES, D.G. Babaçu e seus coprodutos: uma alternativa de renda. Prosa Rural. Embrapa Agroenergia. Disponível em: <http://hotsites.sct.embrapa.br/prosarural/programação/2012>. Acesso em Novembro de 2014.

CORRÊA, C. E.; FISCHER, E.; DOS SANTOS, F. A.M. Seed banks on Attalea phalerata (Arecaceae) stems in the Pantanal wetland, Brazil. Annals of botany, v. 109, n. 4, p. 729-734, 2012. 
DANNER, M. A.; SASSO, S. A. Z.; BITTENCOURT, J. V. M.; CITADIN, I.; SACHET, M. R. Proposta de protocol para extração de DNA de jabuticabeira. Ciência Florestal, Santa Maria, v. 21, n. 2, p. 363-367, abr.-jun., 2011.

DE MESQUITA, B. A. AS MULHERES AGROEXTRATIVISTAS DO BABAÇU: a pobreza a serviço da preservação do meio ambiente.Revista Políticas Públicas, v. 12, n. 1, 2015.

DE OLIVEIRA, R. P.; LONGHI-WAGNER, H. M.; LEITE, K. R. B. A contribuição da anatomia foliar para a taxonomia de RaddiaBertol. (Poaceae: Bambusoideae). Acta bot. bras, v. 22, n. 1, p. 119, 2008.

DeSALLE, R.; EGAN, M. G.; SIDDALL, M. The unholy trinity: taxonomy, species delimitation and DNA barcoding. Philosophical Transactions of the Royal Society of London B: Biological Sciences, v. 360, n. 1462, p. 1905-1916, 2005.

DOYLE, J.J.; DOYLE, J.L. A rapid DNA isolation procedure for small quantities of fresh leaf tissue. Phytochem bull, v. 19, p. 11-15, 1987.

DRANSFIELD, J. et al. A new phylogenetic classification of the palm family, Arecaceae. Kew Bulletin, p. 559-569, 2005.

DRANSFIELD, J. et al. Genera Palmarum: The Evolution and Classification of Palms. Kew, UK: Royal Botanic Garden. 777p. 2008.

EISERHARDT, W. L. et al. Phylogeny and divergence times of Bactridinae (Arecaceae, Palmae) based on plastid and nuclear DNA sequences. Taxon, v. 60, n. 2, p. 485-498, 2011.

ELLIS, R.P. A review of comparative leaf blade anatomy in the systematics of the Poaceae: the past twenty-five years. Pp. 3-10. In: T.R. Soderstrom; K.W. Hilu; C.S. Campbell \& M.E. Barkworth (eds.). Grass Systematics and Evolution. Washington, Smithsonian Institution Press. 1987.

FELSENSTEIN, J. Evolutionary trees from DNA sequences: a maximum likelihood approach. Journal of molecular evolution, v. 17, n. 6, p. 368-376, 1981.

FELSENSTEIN, J. Confidence limits on phylogenies: an approach using the bootstrap. Evolution, p. 783-791, 1985.

FIGUEIREDO, L.D. Embates nos babaçuais. Do espaço doméstico ao espaço público - lutas das quebradeiras de coco babaçu no Maranhão. Dissertação de Mestrado. UFPA - Centro Agropecuário: Embrapa Amazônia Oriental, Belém, PA: 199p. , 2005.

FORD, C. S. et al. Selection of candidate coding DNA barcoding regions for use on land plants. Botanical Journal of the Linnean Society, v. 159, n. 1, p. 1-11, 2009.

GLASSMAN, S. F. A taxonomic treatment of the palm subtribe Attaleinae (Tribe Cocoeae). Illinois biol. Monogr, v. 59, p.416, 1999.

GONZÁLEZ-PÉREZ et al. Conhecimentos e usos do babaçu (Attalea speciosa Mart. E Attalea eichleri (Drude) A. J. Hend.) entre os Mebêngôkre-Kayapó da Terra Indígena Las Casas, estado do Pará, Brasil. Acta Bot. Bras. Vol26. no2. Feira de Santana, Apr/June. 2012. 
GOODMAN, S. M. et al. The use of molecular phylogenetic and morphological tools to identify cryptic and paraphyletic species: Examples from the diminutive long-fingered bats (Chiroptera: Miniopteridae: Miniopterus) on Madagascar. American Museum Novitates, p. 1-34, 2009.

GOVAERTS, R.; DRANSFIELD J. et al. World checklist of palms. Royal botanic gardens, 2005.

GUimarẽes, C. A. L.; SILVA, L. A. M. Piaçava da Bahia (Attalea funifera Martius): do extrativismo à cultura agrícola. 2012.

HALL, T. A. BioEdit: a user-friendly biological sequence alignment editor and analysis program for Windows 95/98/NT. In: Nucleic acids symposium series. p. 95-98.1999.

HEBERT, P. D. N. et al. Biological identifications through DNA barcodes. Proceedings of the Royal Society of London B: Biological Sciences, v. 270, n. 1512, p. 313-321, 2003.

HEBERT, P. D. N. et al. Ten species in one: DNA barcoding reveals cryptic species in the neotropical skipper butterfly Astraptes fulgerator. Proceedings of the National Academy of Sciences of the United States of America, v. 101, n. 41, p. 14812-14817, 2004.

HENDERSON, A.; CHÁVEZ, F. G. GALEANO \& R. BERNAL. Field guide to the palms of the Americas. Princeton University Press, Princepton, New Jersey. 1995.

HENDERSON, A. et al. The palms of the Amazon. Oxford University Press, p.362. 1995.

HIGGINS, D. G.; SHARP, P. M. CLUSTAL: a package for performing multiple sequence alignment on a microcomputer. Gene, v. 73, n. 1, p. 237-244, 1988.

HOLLINGSWORTH, P. M. Refining the DNA barcode for land plants. Proceedings of the National Academy of Sciences, v. 108, n. 49, p. 19451-19452, 2011.

HOLLINGSWORTH, P. M.; GRAHAM, S. W.; LITTLE, D. P. Choosing and using a plant DNA barcode. PloS one, v. 6, n. 5, p. e19254, 2011.

HORN, J. W. et al. Evolution of lamina anatomy in the palm family (Arecaceae). American Journal of Botany, v. 96, n. 8, p. 1462-1486, 2009.

HUBERT, N. et al. Identifying Canadian freshwater fishes through DNA barcodes. PLoS one, v. 3, n. 6, p. e2490, 2008.

IBGE - Instituto Brasileiro de Geografia e Estatística. Produção da Extração Vegetal e da Silvicultura 2009. Disponível em: $<$ http://www.ibge.gov.br/home/estatistica/economia/pevs/2009/default.shtm>. Comunicação Social. Acesso em: 24 nov. 42p. 2010.

IBGE. Instituto Brasileiro de Geografia e Estatística. Produção da extração vegetal e da silvicultura: babaçu. Rio de Janeiro, 2013. Disponível em: <http://www.sidra.ibge.gov.br>. Acesso em: 22 março 2013.

JOHANSEN, D. A. Plantmicrotechinique. MacGraw-Rill Publishing Company LID., Bombay, p.198, 1940.

KATOH, K.; STANDLEY, D. M. MAFFT multiple sequence alignment software version 7: 
improvements in performance and usability. Molecular biology and evolution, v. 30, n. 4, p. 772780, 2013.

KIMURA, M. A simple method for estimating evolutionary rates of base substitutions through comparative studies of nucleotide sequences. Journal of molecular evolution, v. 16, n. 2, p. 111$120,1980$.

KRESS, W. J. et al. Use of DNA barcodes to identify flowering plants.Proceedings of the National Academy of Sciences of the United States of America, v. 102, n. 23, p. 8369-8374, 2005.

KRESS, W. J.; ERICKSON, D. L. A two-locus global DNA barcode for land plants: the coding rbcL gene complements the non-coding trnH-psbA spacer region. Plos one, v. 2, n. 6, p. e508, 2007.

KRESS, W. J. et al. Plant DNA barcodes and a community phylogeny of a tropical forest dynamics plot in Panama. Proceedings of the National Academy of Sciences, v. 106, n. 44, p. 18621-18626, 2009.

LAHAYE, R. et al. DNA barcoding the floras of biodiversity hotspots. Proceedings of the National Academy of Sciences, v. 105, n. 8, p. 2923-2928, 2008.

LARGET, B. et al. A Bayesian analysis of metazoan mitochondrial genome arrangements. Molecular Biology and Evolution, v. 22, n. 3, p. 486-495, 2005.

LEITMAN, P.; HENDERSON, A.; NOBLICK, L. Arecaceae In: Lista de Espécies da Flora do Brasil, Jardim Botânico do Rio de Janeiro, (2014). Jardim Botânico do Rio de Janeiro.In: http://www.floradobrasil.jbrj.gov.br/jabot/listaBrasil/PrincipalUC/PrincipalUC.do. Acesso em novembro de 2014.

LEWIS, C. E.; DOYLE, J. J. A phylogenetic analysis of tribe Areceae (Arecaceae) using two lowcopy nuclear genes. Plant Systematics and Evolution, v. 236, n. 1-2, p. 1-17, 2002.

LIMA, A. M. et al. Utilização de fibras (epicarpo) de babaçu como matéria-prima alternativa na produção de chapas de madeira aglomerada. Revista Árvore, v. 30, n. 4, p. 645-650, 2006.

LIMA, J. R. O. et al. Biodiesel de babaçu (Orbignya sp.) obtido por via etanólica. Quim. Nova, v. 30, n. 3, p. 600-603, 2007.

LIU, Y. J.; WHELEN, S.; HALL, B. D. Phylogenetic relationships among ascomycetes: evidence from an RNA polymerse II subunit. Molecular Biology and Evolution, v. 16, n. 12, p. 1799-1808, 1999.

LOPES, D.N.; SANTOS, B.O.; ARAÚJO, M. G. P. Estudo anatômico dos folíolos de Attalea microcarpa (Arecaceae). 64${ }^{\circ}$ Congresso Nacional de Botânica, Belo Horizonte, Brasil 10-15 de Novembro, 2013.

LORENZI, H. et al. Palmeiras no Brasil: nativas e exóticas. Odessa, São Paulo: Editora Plantarum, 303p. 1996.

LORENZI, H. Árvores Brasileiras: manual de identificação e cultivo de plantas arbóreas do Brasil. 3. Ed. Nova Odessa: Plantarum, v1. 352p. 2000. 
LORENZI, H. et al. Flora brasileira Lorenzi: Arecaceae (palmeiras). Nova Odessa, São Paulo. Instituto Plantarum. 99p. 2010.

MADDISON, W. P.; MADDISON, D. R. Mesquite: a modular system for evolutionary analysis. Version 3.01. 2014.

MALIYAKAL, E. J. An efficient method for isolation of RNAand DNA from plants containing polyphenolics. Nucleic Acids Research, v.2 0, p.2 38 1, 1992.

MARTENS, J.; UHL, N. W.; BAILEY, L. H. Methods for the study of leaf anatomy in palms. Stain technology, v. 55, n. 4, p. 241-246, 1980.

MARTIN, J. T.; JUNIPER, B. E. The cuticles of plants. Edinburgh, Edward Arnold Ltda. 347 p. 1970 .

MARTINS, R. C. A família Arecaceae (Palmae) no estado de Goiás: Florística e etnobotânica. Tese (doutorado)-Universidade de Brasília, Programa de Pós-Graduação em Botânica, Universidade de Brasília. 297p. 2013.

MATOS, D. G. P.; BERNAL, F. S. M.; FARIAS FILHO, M. S. A importância social e econômica do extrativismo do babaçu na microrregião de Itapecuru-mirim, estado do maranhão. In: ANAIS DO XVI ENCONTRO NACIONAL DO GEÓGRAFOS. Anais... ISBN 978:85:99907:02:3 Porto Alegre - RS, 2010.

MAY, P. H. et al. Babassu palm in the agroforestry systems in Brazil's Mid-North region. Agroforestry systems, v. 3, n. 3, p. 275-295, 1985.

MEDEIROS-COSTA, J. T. Cooperação Técnica para fortalecer o Programa de Pesquisa em babaçu. Teresina - PI, 1985. (Relatório final - Pesquisa agropecuária 11.2.SB.1; K.02.SBB.1.10).

MEIER, R. et al. DNA barcoding and taxonomy in Diptera: a tale of high intraspecific variability and low identification success. Systematic biology, v. 55, n. 5, p. 715-728, 2006.

MEIRELLES, J.F. O Livro de Ouro da Amazônia: Mitos e verdades sobre a região mais cobiçada do planeta. 4 ed. São Paulo, Ediouro. 2004.

MEYER, C.P. \& PAULAY, G. DNA barcoding: error rates based on comprehensive sampling. PLoS biol, v. 3, n. 12, p. e422, 2005.

MOLINARI, H. B.; CROCHEMORE, M. L. Extração de DNA genômico de Passiflora spp. para análises PCRRAPD. Revista Brasileira de Fruticultura, v. 23, n. 2, p. 447-450, 2001.

MORTON, B. R.; CLEGG, M. T. A chloroplast DNA mutational hotspot and gene conversion in a noncoding region near rbcL in the grass family (Poaceae). Current Genetics, v. 24, n. 4, p. 357-365, 1993.

MOURA, G. S.; FRANZENER, G. Anatomia foliar de Corymbia citriodora (Hook.) KD Hill \& LAS Johnson oriundas da região noroeste do Paraná-Leaf anatomy of Corymbia citriodora (Hook.) KD Hill \& LAS Johnson coming from Northeast Paraná. Revista de Biologia Neotropical, v. 11, n. 2, p. 116-123, 2015. 
NELSON, L.A.; WALLMAN, J.F.; DOWNTON, M. Using COI barcodes to identify forensically and medically important blowflies. Medical and veterinary entomology, v. 21, n. 1, p. 44-52, 2007.

NEVES, S.C. et al. Diaspore structure and germination ecophysiology of the babassu palm (Attalea vitrivir). Flora-Morphology, Distribution, Functional Ecology of Plants, v. 208, n. 1, p. 68-78, 2013.

NORUP, M. V. et al. Homoplasious character combinations and generic delimitation: a case study from the Indo-Pacific arecoid palms (Arecaceae: Areceae). American journal of botany, v. 93, n. 7 , p. 1065-1080, 2006.

ORTIZ, M. F. Validação do DNA barcoding como identificador de espécies: um estudo de ampla amostragem com o gênero Pseudoplatystoma (siluriformes; pimelodidae) na Amazônia. Dissertação de Mestrado. Instituto Nacional de Pesquisas na Amazônia - INPA. Manaus, Amazonas.73p. 2010.

PINEDO, A. S. et al. Leaf anatomy in Allagoptera (Arecaceae). Botanical Journal of the Linnean Society. April, 2016.

PINHEIRO, C. U. B. Anatomia da folha de $\boldsymbol{O}$. phalerata Martius $\boldsymbol{O}$. eichleri Drude e $\boldsymbol{O}$. teixeirana Bondar (Palmae). Boletim de pesquisa $n^{\circ} 10$, EMBRAPA-UEPAE de Teresina, 31p. 1986.

PINTAUD, J, C. Las palmeras en América del Sur. An overview of the taxonomy of Attalea (Arecaceae). Rev. peru. biol. Novembro, 15(supl. 1): 055- 063. 2008.

POSADA, D. jModelTest: phylogenetic model averaging. Molecular biology and evolution, v. 25, n. 7, p. 1253-1256, 2008.

RABELO, A. Frutas Nativas do Cerrado. Inajá, fruteira amazônica de grande potencial alimentar, industrial e paisagístico. 2013. Disponíevl em: http://frutasnativasdaamazonia.blogspot.com.br/2012/05/normal-0-21-microsoftinternetexplorer 4.html. Acesso em 20/02/2016.

RAMBAUT, A. FigTree, v1. 4.2: Tree Figure Drawing Tool. Molecular evolution, phylogenetics and epidemiology. 2014.

REITZ, R. P. In: R. REITZ, Ed. Flora ilustrada catarinense. Herbário Barbosa Rodrigues, Itajaí.124p. 1974.

RONCAL, J. et al. Molecular phylogenetics of tribe Geonomeae (Arecaceae) using nuclear DNA sequences of phosphoribulokinase and RNA polymerase II. Systematic Botany, v. 30, n. 2, p. 275$283,2005$.

RONQUIST, F.; HUELSENBECK J. P. MrBayes 3: Bayesian phylogenetic inference under mixed models. Bioinformatics, v. 19, n. 12, p. 1572-1574, 2003.

RUBINOFF, D. Utility of mitochondrial DNA barcodes in species conservation. Conservation Biology, v. 20, n. 4, p. 1026-1033, 2006.

RUSSELL, A. et al. Phylogenetics and cytology of a pantropical orchid genus Polystachya (Polystachyinae, Vandeae, Orchidaceae): evidence from plastid DNA sequence data. Taxon, p. 389- 
404, 2010.

SANG, T. et al. Chloroplast DNA phylogeny, reticulate evolution, and biogeography of Paconia (Paconiaceae). American Journal of Botany. 84:1120-1136. 1997.

SANTOS, M. F. et al. Utilização de primers RAPD para estudo de diversidade genética de acessos de babaçu (orbignya phalerata mart) coletados de diferentes regiões. In: CONGRESSO BRASILEIRO DE PLANTAS OLEAGINOSAS, ÓLEOS, GORDURAS E BIODIESEL, 5.; CLÍNICA TECNOLÓGICA EM BIODIESEL, 2., 2008, Lavras. Biodiesel: tecnologia limpa. Anais... Lavras: UFLA, 6p. 2008.

SANTOS, N. C.; SILVA, L. B.; LEITE, K. R. B. Anatomia foliar comparada de Attalea barreirenses glassman e Attalea geraensis barb.rodr. (Arecaceae) como subsídio à taxonomia do gênero. In: $\mathbf{6 2}^{\circ}$ CONGRESSO NACIONAL DE BOTÂNICA, 07 a 12 de Agosto, Frotaleza, Ceará, Brasil. 2011.

SILVA-BRANDAO, K. L.; LYRA, M. L.; FREITAS, A. V. L. Barcoding Lepidoptera: current situation and perspectives on the usefulness of a contentious technique. Neotropical entomology, $v$. 38, n. 4, p. 441-451, 2009.

SILVA, R. J. F. \& POTIGUARA R. C. V. Aplicações taxonômicas da anatomia foliar de espécies amazônicas de Oenocarpus Mart. (Arecaceae). Acta Botanica Brasilica. 22: 999-1014. 2008.

SILVEIRA, A. Programa Ambiental: A Última Arca de Noé - Attalea funifera (Piaçava; Attalea palm). 2013. Disponíel em: http://www.aultimaarcadenoe.com.br/attalea-funifera/. Acesso em 20/02/2016.

SITTOLIN, I. M. et al. Documentação e informatização do banco ativo de germoplasma de babaçu da Embrapa Meio-Norte (EMBRAPA CPAMN), Teresina, PI. In: SIMPÓSIO BRASILEIRO DE RECURSOS GENÉTICOS, 2., 2008, Brasília, DF. Anais... Brasília, DF: Embrapa Recursos Genéticos e Biotecnologia, 2008.

SNEATH, P. H. A. \& SOKAL R. R. Numerical taxonomy. The principles and practice of numerical classification. 1973.

SOUZA M. H. S. L. et al. Ethnopharmacological use of babassu (Orbignya phalerata Mart) in communities of babassu nut breakers in Maranhão, Brazil. J. Ethnopharmacol. 133: 1-5, 2011.

SOUZA, H. A. et al. Isolation of high quality and polysaccharide-free DNA from leaves of Dimorphandra mollis (Leguminosae), a tree from the Brazilian Cerrado. Genet Mol Res, v. 11, p. 756-764, 2012.

STACE, C. A. Cuticular studies as an aid to plant taxonomy. Bull. Brit. Mus.(Nat. Hist.) Bot, v. 4, n. 1, p. 3-78, 1965.

SUGITA, M.; SHINOZAKI, K.; SUGIURA, M. Tobacco chloroplast tRNALys (UUU) gene contains a 2.5-kilobase-pair intron: an open reading frame and a conserved boundary sequence in the intron. Proceedings of the National Academy of Sciences, v. 82, n. 11, p. 3557-3561, 1985.

SWOFFORD, D. L. PAUP*: Phylogenetic analysis using parsimony, version 4.0 b4a. Illinois Natural History Survey, Champaign, Sunderland, MA: Sinauer Associates. 2002.

TABERLET, P. et al. Universal primers for amplification of three non-coding regions of chloroplast 
DNA. Plant molecular biology, v. 17, n. 5, p. 1105-1109, 1991.

TAMURA, K.; NEI, M.; KUMAR, S. Prospects for inferring very large phylogenies by using the neighbor-joining method. Proceedings of the National Academy of Sciences of the United States of America, v. 101, n. 30, p. 11030-11035, 2004.

TAMURA, K. et al. MEGA6: molecular evolutionary genetics analysis version 6.0. Molecular biology and evolution, p. mst197, 2013.

THOMAS, M. M. et al. Molecular phylogeny of the palm genus Chamaedorea, based on the lowcopy nuclear genes PRK and RPB2. Molecular phylogenetics and evolution, v. 38, n. 2, p. 398415, 2006.

TOMLINSON, P. B. Anatomy of the monocotyledons. II. Palmae. Oxford University Press, Oxford, UK. 1961.

TOMLINSON, P. B. The structural biology of palms. Oxford University Press, 465p. 1990.

TOMLINSON, P. B.; HORN, J. W.; FISHER, J. B. The anatomy of palms: Arecaceae-Palmae. New York: Oxford University Press, 2011.

UHL, N. W.; DRANSFIELD, J. Genera Palmarum A Classification of Palms Based on the Work of Harold E. Moore, Jr. Allen Press, Kansas, 610p.1987.

WHITE, T. J. et al. Amplification and direct sequencing of fungal ribosomal RNA genes for phylogenetics. PCR protocols: a guide to methods and applications, v. 18, n. 1, p. 315-322, 1990. 
ANEXOS 


\section{Anexo I}

Tabela 15. Dados morfológicos analisados como presença (1) e ausência (0) das características de cada uma das sete espécies de Attalea

\begin{tabular}{|c|c|c|c|c|c|c|c|}
\hline Caracteres morfológicos & A. speciosa & A. barreirensis & A. eichleri & A. funifera & A. maripa & A. phalerata & A. vitrivir \\
\hline $\begin{array}{l}\text { Lamina foliar plana adaxialmente (0) ou com } \\
\text { ondulações (1) }\end{array}$ & 0 & 1 & 1 & 1 & 1 & 0 & 1 \\
\hline $\begin{array}{l}\text { Lamina foliar plana abaxialmente (0) ou com } \\
\text { ondulações (1) }\end{array}$ & 1 & 1 & 1 & 1 & 1 & 1 & 1 \\
\hline Tricomas glandulares presentes em ambas as faces & 1 & 1 & 1 & 1 & 1 & 1 & 1 \\
\hline $\begin{array}{l}\text { Células da epiderma adaxial lisas(0) ou com } \\
\text { ondulações(1) }\end{array}$ & 1 & 0 & 0 & 1 & 1 & 0 & 0 \\
\hline $\begin{array}{l}\text { Células da epiderma abaxial lisas(0) ou com } \\
\text { ondulações(1) }\end{array}$ & 1 & 0 & 0 & 0 & 1 & 0 & 1 \\
\hline Cutícula adaxial delgada (0) ou espessa (1) & 0 & 1 & 1 & 0 & 1 & 0 & 0 \\
\hline Cutícula abaxial delgada(0) ou espessa (1) & 0 & 1 & 1 & 1 & 1 & 1 & 1 \\
\hline $\begin{array}{l}\text { Células comuns da epiderme adaxial } \\
\text { predominantemente retangulares }\end{array}$ & 1 & 1 & 1 & 1 & 1 & 1 & 1 \\
\hline $\begin{array}{l}\text { Células comuns da epiderme abaxial } \\
\text { predominantemente retangulares }\end{array}$ & 1 & 1 & 1 & 0 & 1 & 1 & 1 \\
\hline Pinas hipoestomáticas (1) ou anfiestomáticas (0) & 1 & 0 & 1 & 1 & 1 & 1 & 1 \\
\hline Complexo estomático tetracítico & 1 & 1 & 1 & 1 & 1 & 1 & 1 \\
\hline Estômatos dispostos regularmente em fileiras & 1 & 1 & 1 & 1 & 1 & 1 & 1 \\
\hline Câmaras subestomáticas presentes $(\mathbf{1})$ ausentes $(\mathbf{0})$ & 1 & 1 & 0 & 0 & 0 & 0 & 1 \\
\hline Cristas estomáticas ausentes & 1 & 1 & 1 & 1 & 1 & 1 & 1 \\
\hline
\end{tabular}


Continuação da Tabela 15. Dados morfológicos analisados como presença (1) e ausência (0) das características de cada uma das sete espécies de Attalea.

\begin{tabular}{|c|c|c|c|c|c|c|c|}
\hline Caracteres morfológicos & A. speciosa & A. barreirensis & A. eichleri & A. funifera & A. maripa & A. phalerata & A. vitrivir \\
\hline Células subsidiárias laterais reniformes & 1 & 1 & 1 & 0 & 0 & 1 & 1 \\
\hline $\begin{array}{l}\text { Células subsidiárias polares com formato reniforme (1) } \\
\text { ou trapezoides (0) }\end{array}$ & 1 & 1 & 1 & 1 & 1 & 0 & 0 \\
\hline Células buliformes retangulares & 1 & 1 & 1 & 1 & 1 & 1 & 1 \\
\hline Mesofilo dorsiventral & 1 & 1 & 1 & 1 & 1 & 1 & 1 \\
\hline $\begin{array}{l}\text { Parênquima paliçádico com } 1 \text { camadas de células }(0) \text { ou } \\
\text { com 2-3 camadas de células (1) }\end{array}$ & 0 & 1 & 1 & 0 & 0 & 0 & 1 \\
\hline Hipoderme adaxial delgada (0) ou espessa (1) & 1 & 1 & 1 & 0 & 0 & 0 & 0 \\
\hline Hipoderme abaxial delgada (0) ou espessa (1) & 1 & 1 & 1 & 0 & 0 & 0 & 0 \\
\hline Feixe vascular principal colateral, ovoide, livre & 1 & 1 & 1 & 1 & 1 & 1 & 1 \\
\hline $\begin{array}{l}\text { Segmento da nervura principal com formato triangular } \\
\text { (0) ou com formato trapezoide (1) }\end{array}$ & 1 & 0 & 1 & 0 & 1 & 1 & 0 \\
\hline $\begin{array}{l}\text { Segmento da nervura principal com ângulos } \\
\text { arredondados (0) ou com ângulos obtusos (1) }\end{array}$ & 1 & 1 & 1 & 1 & 0 & 0 & 1 \\
\hline $\begin{array}{l}\text { Feixes vasculares de primeira ordem adaxialmente } \\
\text { livres }(0) \text { ou travados (1) }\end{array}$ & 1 & 1 & 1 & 0 & 0 & 0 & 1 \\
\hline $\begin{array}{l}\text { Feixes vasculares de primeira ordem abaxialmente } \\
\text { livres (0) ou travados (1) }\end{array}$ & 1 & 0 & 1 & 0 & 1 & 1 & 0 \\
\hline $\begin{array}{l}\text { Feixes vasculares de segunda ordem adaxialmente } \\
\text { livres (0) ou travados (1) }\end{array}$ & 0 & 0 & 0 & 0 & 0 & 0 & 0 \\
\hline $\begin{array}{l}\text { Feixes vasculares de segunda ordem abaxialmente } \\
\text { livres (0) ou travados (1) }\end{array}$ & 1 & 0 & 1 & 1 & 1 & 1 & 0 \\
\hline
\end{tabular}


Continuação da Tabela 15. Dados morfológicos analisados como presença (1) e ausência (0) das características de cada uma das sete espécies de Attalea.

\begin{tabular}{|c|c|c|c|c|c|c|c|}
\hline Caracteres morfológicos & A. speciosa & A. barreirensis & A. eichleri & A. funifera & A. maripa & A. phalerata & A. vitrivir \\
\hline $\begin{array}{l}\text { Feixes vasculares de terceira ordem } \\
\text { adaxialmente livres (0) ou travados (1) }\end{array}$ & 0 & 0 & 0 & 0 & 0 & 0 & 0 \\
\hline $\begin{array}{l}\text { Feixes vasculares de terceira ordem abaxialmente } \\
\text { livres (0) ou travados (1) }\end{array}$ & 1 & 1 & 1 & 1 & 1 & 1 & 1 \\
\hline $\begin{array}{l}\text { Fibras permeando a hipoderme adaxial, ausência(0) ou } \\
\text { presença(1) }\end{array}$ & 1 & 1 & 1 & 1 & 1 & 1 & 0 \\
\hline $\begin{array}{l}\text { Fibras permeando a hipoderme abaxial ausência(0) ou } \\
\text { presença(1) }\end{array}$ & 1 & 1 & 0 & 0 & 1 & 0 & 1 \\
\hline $\begin{array}{l}\text { Margem foliar com ângulo agudo ou obtuso (1),ou } \\
\text { arredondado (0) }\end{array}$ & 1 & 0 & 1 & 1 & 0 & 0 & 1 \\
\hline $\begin{array}{l}\text { Grupos de fibras marginais circulares permeando as } \\
\text { células buliformes }\end{array}$ & 1 & 1 & 1 & 1 & 1 & 1 & 1 \\
\hline $\begin{array}{l}\text { Células buliformes na margem foliar ausência (0) ou } \\
\text { presença(1) }\end{array}$ & 0 & 0 & 0 & 0 & 0 & 1 & 0 \\
\hline
\end{tabular}




\section{Anexo II.}

Tabela 16. Amostras de Attalea com suas respectivas informações de coleta.

\begin{tabular}{|c|c|}
\hline A. teixeirana-híb-BA1 & Perinã. Localidade: Grajaú, MA, S 06 00' 45.80640" W 46 03' 34.06680" \\
\hline A. teixeirana-híb-BA4 & "eichleri grande". Localidade: Grajaú, MA, S 06 00' 46.72440" W 46 03' 32.02920" \\
\hline A. teixeirana-híb-BA39 & "speciosa alta". Localidade: Grajaú, MA, S 06 00' 52.92000" W 46 03' 40.46040" \\
\hline A. teixeirana - híb-CT22 & $\begin{array}{l}\text { Intermediária entre pindova e "eichleri grande". Localidade: Caxias, MA, S } 0453 \text { ' 46.26240"W } 4315 \text { ' } \\
41.78160 "\end{array}$ \\
\hline A. teixeirana- híb-CT01 & Pindova, acaule. Localidade: Caxias, MA, S 04 53' 47.64840" W 43 15' 38.33280" \\
\hline A. teixeirana-híb-CT02 & Pindova, acaule. Localidade: Caxias, MA, S 04 53' 47.40720"' W 43 15' 38.81520" \\
\hline A. teixeirana-híb-CT16 & "eichleri grande". Localidade: Caxias, MA, S 04 53' 46.28040" W 43 15' 41.41440" \\
\hline A. teixeirana - híb - СТ20 & "eichleri grande". Localidade: Caxias, MA, S 04 53' 46.19400" W 43 15' 41.55840" \\
\hline A. teixeirana-híb-CT37 & Pindova. Localidade: Caxias, MA, S 04 53' 44.21760"' W 43 15' 39.17520"' \\
\hline A. teixeirana-híb-CT38 & "eichleri grande". Localidade: Caxias, MA, S 04 53' 43.52640" W 43 15' 38.57400" \\
\hline A. teixeirana - híb - LA19 & "speciosa baixa", talvez perinã. Localidade: Lajeado Novo, MA, S 06 12' 13.68720" W 4702 ' 48.35040" \\
\hline A. teixeirana-híb-FZ12 & Localidade: Grajaú, MA, S 05 37' 24.43440" W 46 13' 58.97280" \\
\hline A. barreirensis - B1 & População (pop. 21). Localidade: São Raimundo das Mangabeiras, MA, S $07^{\circ} 11^{\prime} 32.5^{\prime \prime}$ W $45^{\circ} 48^{\prime} 12.8^{\prime \prime}$ \\
\hline A. barreirensis - B2 & 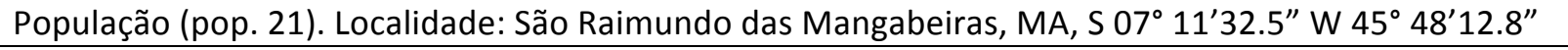 \\
\hline A. barreirensis - B3 & População (pop. 21). Localidade: São Raimundo das Mangabeiras, MA, S $07^{\circ} 11^{\prime} 32.5^{\prime \prime}$ W $45^{\circ} 48^{\prime} 12.8^{\prime \prime}$ \\
\hline A. barreirensis - B4 & 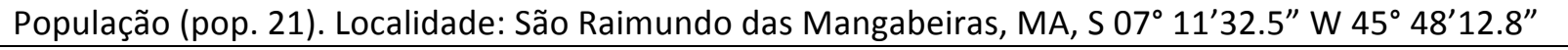 \\
\hline A. barreirensis - B5 & População (pop. 21). Localidade: São Raimundo das Mangabeiras, MA, S $07^{\circ} 11^{\prime} 32.5^{\prime \prime}$ W $45^{\circ} 48^{\prime} 12.8^{\prime \prime}$ \\
\hline A. barreirensis - B6 & População (pop. 21). Localidade: São Raimundo das Mangabeiras, MA, S $07^{\circ} 11^{\prime} 32.5^{\prime \prime}$ W $45^{\circ} 48^{\prime} 12.8^{\prime \prime}$ \\
\hline A. barreirensis - B7 & 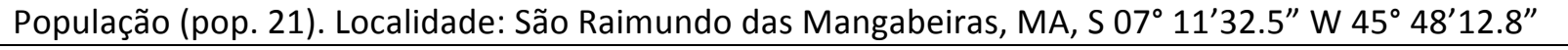 \\
\hline A. barreirensis - B8 & 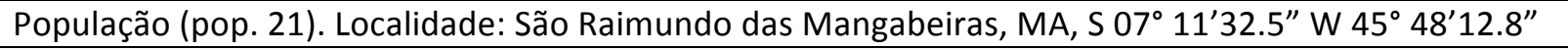 \\
\hline A. barreirensis - B9 & 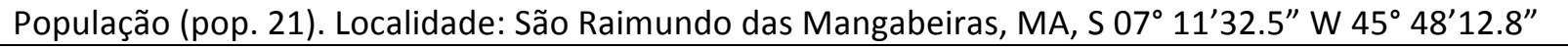 \\
\hline A. barreirensis - B10 & 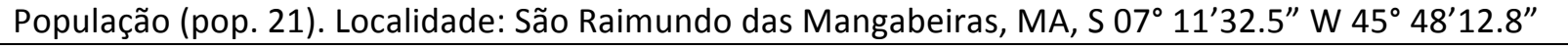 \\
\hline A. barreirensis - B11 & População (pop. 21). Localidade: São Raimundo das Mangabeiras, MA, S $07^{\circ} 11^{\prime} 32.5^{\prime \prime}$ W $45^{\circ} 48^{\prime} 12.8^{\prime \prime}$ \\
\hline A. barreirensis - B12 & População (pop. 21). Localidade: São Raimundo das Mangabeiras, MA, S $07^{\circ} 11^{\prime} 32.5^{\prime \prime}$ W $45^{\circ} 48^{\prime} 12.8^{\prime \prime}$ \\
\hline A. barreirensis - B15 & 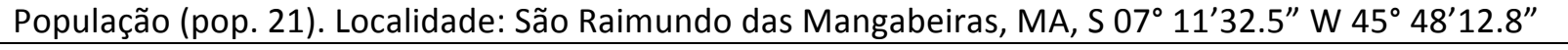 \\
\hline A. barreirensis - B16 & População (pop. 21). Localidade: São Raimundo das Mangabeiras, MA, S $07^{\circ} 11^{\prime} 32.5^{\prime \prime}$ W $45^{\circ} 48^{\prime} 12.8^{\prime \prime}$ \\
\hline A. barreirensis - B17 & 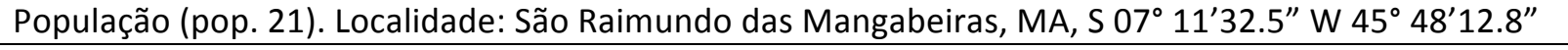 \\
\hline A. eichleri - E04 & População (pop. 18). Localidade: Carolina, MA, S $07^{\circ} 24^{\prime} 40.9^{\prime \prime}$ W $47^{\circ} 04^{\prime} 46.2^{\prime \prime}$ \\
\hline
\end{tabular}




\begin{tabular}{|c|c|}
\hline A. eichleri - E17 & População (pop. 18). Localidade: Carolina, MA, S $07^{\circ} 24^{\prime} 40.9^{\prime \prime}$ W 4704' 46.2" \\
\hline A. eichleri-E18 & População (pop. 18). Localidade: Carolina, MA, S $07^{\circ} 24^{\prime} 40.9^{\prime \prime}$ W $47^{\circ} 04^{\prime} 46.2^{\prime \prime}$ \\
\hline A. eichleri-E19 & População (pop. 18). Localidade: Carolina, MA, S $07^{\circ} 24^{\prime} 40.9^{\prime \prime}$ W 4704' 46.2" \\
\hline A. eichleri - E11 & População (pop. 18). Localidade: Carolina, MA, S $07^{\circ} 24^{\prime} 40.9^{\prime \prime}$ W $47^{\circ} 04^{\prime} 46.2^{\prime \prime}$ \\
\hline A. eichleri - СТ07 & População (pop. 18). Localidade: Carolina, MA, S $07^{\circ} 24^{\prime} 40.9^{\prime \prime}$ W $47^{\circ} 04^{\prime} 46.2^{\prime \prime}$ \\
\hline A. eichleri-ES22 & Localidade: Estreito, MA, S 06 50' 19.00680" W 47 26' 34.05480" \\
\hline A. funifera - 1 & Coleção particular do Carlos Alex na Bahia \\
\hline A. funifera - 2 & Coleção particular do Carlos Alex na Bahia \\
\hline A. funifera - 3 & Coleção particular do Carlos Alex na Bahia \\
\hline A. funifera - 4 & Coleção particular do Carlos Alex na Bahia \\
\hline A. funifera - 5 & Coleção particular do Carlos Alex na Bahia \\
\hline A. funifera - 6 & Coleção particular do Carlos Alex na Bahia \\
\hline A. funifera - 7 & Coleção particular do Carlos Alex na Bahia \\
\hline A. funifera - 8 & Coleção particular do Carlos Alex na Bahia \\
\hline A. funifera - 9 & Coleção particular do Carlos Alex na Bahia \\
\hline A. funifera - 10 & Coleção particular do Carlos Alex na Bahia \\
\hline A. funifera - 11 & Coleção particular do Carlos Alex na Bahia \\
\hline A. funifera - 12 & Coleção particular do Carlos Alex na Bahia \\
\hline A. funifera - 15 & Coleção particular do Carlos Alex na Bahia \\
\hline A. maripa - 1 & Coleção particular do Carlos Alex na Bahia \\
\hline A. maripa - 4 & Coleção particular do Carlos Alex na Bahia \\
\hline A. maripa - 5 & Coleção particular do Carlos Alex na Bahia \\
\hline A. maripa - 6 & Coleção particular do Carlos Alex na Bahia \\
\hline A. maripa - 7 & Coleção particular do Carlos Alex na Bahia \\
\hline A. maripa - 10 & Coleção particular do Carlos Alex na Bahia \\
\hline A. maripa - 15 & Coleção particular do Carlos Alex na Bahia \\
\hline A. maripa - 16 & Coleção particular do Carlos Alex na Bahia \\
\hline A. maripa - 12 & Coleção particular do Carlos Alex na Bahia \\
\hline A. phalerata - P12 & População (pop.15). Localidade: Tocantinópolis, TO, S $06^{\circ} 30^{\prime} 15.7^{\prime \prime W} 47^{\circ} 28^{\prime} 51.0^{\prime \prime}$ \\
\hline A. phalerata - P30 & População (pop.17). Localidade: Carolina, MA, S 07²4' 47.9"W 47 10' 45.3" \\
\hline A. phalerata-P36 & População (pop.17). Localidade: Carolina, MA, S 07² 24' 47.9"W 47 10' 45.3" \\
\hline A. speciosa-CT46 & Localidade: Caxias, MA, S 04 53' 41.67960" W 43 15' 38.52000" \\
\hline A. speciosa-CT47 & Localidade: Caxias, MA, S 04 53' 41.44560" W 43 15' 39.18240" \\
\hline A. speciosa-S6 & População (pop.12). Localidade: Nazaré, TO, S 06² 23' 26.6"W 47 38' 01.4" \\
\hline
\end{tabular}




\begin{tabular}{|c|c|}
\hline A. speciosa-S7 & População (pop.12). Localidade: Nazaré, TO, S 06² 23' 26.6"W 47³8' 01.4" \\
\hline A. speciosa-S9 & População (pop.12). Localidade: Nazaré, TO, S $06^{\circ} 23^{\prime} 26.6^{\prime \prime W ~ 47^{\circ} 38^{\prime} 01.4^{\prime \prime}}$ \\
\hline A. speciosa-S3 & População (pop.12). Localidade: Nazaré, TO, S 06² 23' 26.6"W 47³ 38' 01.4" \\
\hline A. speciosa-S4 & População (pop.12). Localidade: Nazaré, TO, S $06^{\circ} 23^{\prime} 26.6^{\prime \prime W ~ 47^{\circ} 38^{\prime} 01.4^{\prime \prime}}$ \\
\hline A. speciosa-S5 & População (pop.12). Localidade: Nazaré, TO, S 06² 23' 26.6"W 47³ 38' 01.4" \\
\hline A. speciosa-S8 & População (pop.12). Localidade: Nazaré, TO, S 06² 23' 26.6"W 47 38' 01.4" \\
\hline A. speciosa-S17 & População (pop.12). Localidade: Nazaré, TO, S 06² 23' 26.6"W 47³ 38' 01.4" \\
\hline A. vitriviri - 1BM & Bonito de Minas (MG), próximo de Montes Claros - Fornecido Universidade Estadual de Montes Claros \\
\hline A. vitriviri - 2BM & Bonito de Minas (MG), próximo de Montes Claros - Fornecido Universidade Estadual de Montes Claros \\
\hline A. vitriviri - 1M1 & Montalvânia - MG - Divisa de MG com o sul da Bahia - Fornecido Universidade Estadual de Montes Claros \\
\hline A. vitriviri - $2 \mathrm{M} 1$ & Montalvânia - MG - Divisa de MG com o sul da Bahia - Fornecido Universidade Estadual de Montes Claros \\
\hline A. vitriviri - 8BM & Bonito de Minas (MG), próximo de Montes Claros - Fornecido Universidade Estadual de Montes Claros \\
\hline
\end{tabular}


Anexo III. Tabelas de distâncias de Kimura 2P

Tabela 17. Estimativa de distâncias par a par entre as sequências de Attalea geradas para o marcador $\boldsymbol{r b c \boldsymbol { L }}$ (Kimura 2P)

\begin{tabular}{|c|c|c|c|c|c|c|c|c|c|c|c|c|c|c|c|c|c|c|c|}
\hline & & 1 & 2 & 3 & 4 & 5 & 6 & 7 & 8 & 9 & 10 & 11 & 12 & 13 & 14 & 15 & 16 & 17 & 18 \\
\hline 1 & A. eichleri-UB1091 & & & & & & & & & & & & & & & & & & \\
\hline 2 & A. phalerata - UB238 & 0,00 & & & & & & & & & & & & & & & & & \\
\hline 3 & A. speciosa - UB10110 & 0,00 & 0,00 & & & & & & & & & & & & & & & & \\
\hline 4 & A. barreirensis - UB36868 & 0,00 & 0,00 & 0,00 & & & & & & & & & & & & & & & \\
\hline 5 & A. speciosa - CEN58039 & 0,00 & 0,00 & 0,00 & 0,00 & & & & & & & & & & & & & & \\
\hline 6 & A. maripa - CEN12546 & 0,00 & 0,00 & 0,00 & 0,00 & 0,00 & & & & & & & & & & & & & \\
\hline 7 & A. barreirensis - B15 & 0,00 & 0,00 & 0,00 & 0,00 & 0,00 & 0,00 & & & & & & & & & & & & \\
\hline 8 & A. barreirensis - B16 & 0,00 & 0,00 & 0,00 & 0,00 & 0,00 & 0,00 & 0,00 & & & & & & & & & & & \\
\hline 9 & A. barreirensis - B17 & 0,00 & 0,00 & 0,00 & 0,00 & 0,00 & 0,00 & 0,00 & 0,00 & & & & & & & & & & \\
\hline 10 & A. eichleri-E17 & 0,00 & 0,00 & 0,00 & 0,00 & 0,00 & 0,00 & 0,00 & 0,00 & 0,00 & & & & & & & & & \\
\hline 11 & A. eichleri-E18 & 0,00 & 0,00 & 0,00 & 0,00 & 0,00 & 0,00 & 0,00 & 0,00 & 0,00 & 0,00 & & & & & & & & \\
\hline 12 & A. eichleri-E19 & 0,00 & 0,00 & 0,00 & 0,00 & 0,00 & 0,00 & 0,00 & 0,00 & 0,00 & 0,00 & 0,00 & & & & & & & \\
\hline 13 & A. funifera -7 & 0,00 & 0,00 & 0,00 & 0,00 & 0,00 & 0,00 & 0,00 & 0,00 & 0,00 & 0,01 & 0,00 & 0,00 & & & & & & \\
\hline 14 & A. maripa -10 & 0,00 & 0,00 & 0,00 & 0,00 & 0,00 & 0,00 & 0,00 & 0,00 & 0,00 & 0,00 & 0,00 & 0,00 & 0,00 & & & & & \\
\hline 15 & A. maripa -15 & 0,00 & 0,00 & 0,00 & 0,00 & 0,00 & 0,00 & 0,00 & 0,00 & 0,00 & 0,00 & 0,00 & 0,00 & 0,00 & 0,00 & & & & \\
\hline 16 & A. phalerata-P12 & 0,00 & 0,00 & 0,00 & 0,00 & 0,00 & 0,00 & 0,00 & 0,00 & 0,00 & 0,00 & 0,00 & 0,00 & 0,00 & 0,00 & 0,00 & & & \\
\hline 17 & A. phalerata-P30 & 0,00 & 0,00 & 0,00 & 0,00 & 0,00 & 0,00 & 0,00 & 0,00 & 0,00 & 0,00 & 0,00 & 0,00 & 0,00 & 0,00 & 0,00 & 0,00 & & \\
\hline 18 & A. phalerata-P36 & 0,00 & 0,00 & 0,00 & 0,00 & 0,00 & 0,00 & 0,00 & 0,00 & 0,00 & 0,00 & 0,00 & 0,00 & 0,00 & 0,00 & 0,00 & 0,00 & 0,00 & \\
\hline 19 & A. speciosa - \$5 & 0,00 & 0,00 & 0,00 & 0,00 & 0,00 & 0,00 & 0,00 & 0,00 & 0,00 & 0,00 & 0,00 & 0,00 & 0,00 & 0,00 & 0,00 & 0,00 & 0,00 & 0,00 \\
\hline 20 & A. speciosa - \$4 & 0,00 & 0,00 & 0,00 & 0,00 & 0,00 & 0,00 & 0,00 & 0,00 & 0,00 & 0,00 & 0,00 & 0,00 & 0,00 & 0,00 & 0,00 & 0,00 & 0,00 & 0,00 \\
\hline 21 & A. allenii - AJ404829.1 & 0,00 & 0,00 & 0,00 & 0,00 & 0,00 & 0,00 & 0,00 & 0,00 & 0,00 & 0,00 & 0,00 & 0,00 & 0,00 & 0,00 & 0,00 & 0,00 & 0,00 & 0,00 \\
\hline 22 & A. butyracea - JQ590420.1 & 0,00 & 0,00 & 0,00 & 0,00 & 0,00 & 0,00 & 0,00 & 0,00 & 0,00 & 0,00 & 0,00 & 0,00 & 0,00 & 0,00 & 0,00 & 0,00 & 0,00 & 0,00 \\
\hline 23 & A. rostrata - GQ981675.1 & 0,00 & 0,00 & 0,00 & 0,00 & 0,00 & 0,00 & 0,00 & 0,00 & 0,00 & 0,00 & 0,00 & 0,00 & 0,00 & 0,00 & 0,00 & 0,00 & 0,00 & 0,00 \\
\hline 24 & A. teixeirana - híb - BA1 & 0,00 & 0,00 & 0,00 & 0,00 & 0,00 & 0,00 & 0,00 & 0,00 & 0,00 & 0,00 & 0,00 & 0,00 & 0,00 & 0,00 & 0,00 & 0,00 & 0,00 & 0,00 \\
\hline 25 & A. teixeirana - híb-BA4 & 0,00 & 0,00 & 0,00 & 0,00 & 0,00 & 0,00 & 0,00 & 0,00 & 0,00 & 0,00 & 0,00 & 0,00 & 0,00 & 0,00 & 0,00 & 0,00 & 0,00 & 0,00 \\
\hline 26 & A. teixeirana - híb - BA39 & 0,00 & 0,00 & 0,00 & 0,00 & 0,00 & 0,00 & 0,00 & 0,00 & 0,00 & 0,01 & 0,00 & 0,00 & 0,00 & 0,00 & 0,00 & 0,00 & 0,00 & 0,00 \\
\hline 27 & A. teixeirana - híb-CT01 & 0,00 & 0,00 & 0,00 & 0,00 & 0,00 & 0,00 & 0,00 & 0,00 & 0,00 & 0,00 & 0,00 & 0,00 & 0,00 & 0,00 & 0,00 & 0,00 & 0,00 & 0,00 \\
\hline 28 & A. teixeirana - híb - CT02 & 0,00 & 0,00 & 0,00 & 0,00 & 0,00 & 0,00 & 0,00 & 0,00 & 0,00 & 0,00 & 0,00 & 0,00 & 0,00 & 0,00 & 0,00 & 0,00 & 0,00 & 0,00 \\
\hline 29 & A. teixeirana - híb - CT20 & 0,00 & 0,00 & 0,00 & 0,00 & 0,00 & 0,00 & 0,00 & 0,00 & 0,00 & 0,00 & 0,00 & 0,00 & 0,00 & 0,00 & 0,00 & 0,00 & 0,00 & 0,00 \\
\hline 30 & A. teixeirana - híb-CT37 & 0,00 & 0,00 & 0,00 & 0,00 & 0,00 & 0,00 & 0,00 & 0,00 & 0,00 & 0,00 & 0,00 & 0,00 & 0,00 & 0,00 & 0,00 & 0,00 & 0,00 & 0,00 \\
\hline 31 & A. teixeirana - híb-CT22 & 0,00 & 0,00 & 0,00 & 0,00 & 0,00 & 0,00 & 0,00 & 0,00 & 0,00 & 0,00 & 0,00 & 0,00 & 0,00 & 0,00 & 0,00 & 0,00 & 0,00 & 0,00 \\
\hline 32 & A. teixeirana - híb - СТ38 & 0,00 & 0,00 & 0,00 & 0,00 & 0,00 & 0,00 & 0,00 & 0,00 & 0,00 & 0,00 & 0,00 & 0,00 & 0,00 & 0,00 & 0,00 & 0,00 & 0,00 & 0,00 \\
\hline 33 & A. speciosa - CT47 & 0,00 & 0,00 & 0,00 & 0,00 & 0,00 & 0,00 & 0,00 & 0,00 & 0,00 & 0,00 & 0,00 & 0,00 & 0,00 & 0,00 & 0,00 & 0,00 & 0,00 & 0,00 \\
\hline 34 & A. eichleri-ES22 & 0,00 & 0,00 & 0,00 & 0,00 & 0,00 & 0,00 & 0,00 & 0,00 & 0,00 & 0,01 & 0,00 & 0,00 & 0,00 & 0,00 & 0,00 & 0,00 & 0,00 & 0,00 \\
\hline 35 & Cocos nucifera - AY012507.1 & 0,00 & 0,00 & 0,00 & 0,00 & 0,00 & 0,00 & 0,00 & 0,00 & 0,00 & 0,00 & 0,00 & 0,00 & 0,00 & 0,00 & 0,00 & 0,00 & 0,00 & 0,00 \\
\hline
\end{tabular}


Continuação da Tabela 17. Continuação das estimativas de distâncias par a par entre as sequências de Attalea geradas para o marcador $r b c L$ (Kimura 2P)

\begin{tabular}{|c|c|c|c|c|c|c|c|c|c|c|c|c|c|c|c|c|c|c|c|}
\hline & & 1 & 2 & 3 & 4 & 5 & 6 & 7 & 8 & 9 & 10 & 11 & 12 & 13 & 14 & 15 & 16 & 17 & 18 \\
\hline 1 & A. eichleri-UB1091 & & & & & & & & & & & & & & & & & & \\
\hline 2 & A. phalerata-UB238 & 0,00 & & & & & & & & & & & & & & & & & \\
\hline 3 & A. speciosa - UB10110 & 0,00 & 0,00 & & & & & & & & & & & & & & & & \\
\hline 4 & A. barreirensis - UB36868 & 0,00 & 0,00 & 0,00 & & & & & & & & & & & & & & & \\
\hline 5 & A. speciosa - CEN58039 & 0,00 & 0,00 & 0,00 & 0,00 & & & & & & & & & & & & & & \\
\hline 6 & A. maripa - CEN12546 & 0,00 & 0,00 & 0,00 & 0,00 & 0,00 & & & & & & & & & & & & & \\
\hline 7 & A. barreirensis - B15 & 0,00 & 0,00 & 0,00 & 0,00 & 0,00 & 0,00 & & & & & & & & & & & & \\
\hline 8 & A. barreirensis - B16 & 0,00 & 0,00 & 0,00 & 0,00 & 0,00 & 0,00 & 0,00 & & & & & & & & & & & \\
\hline 9 & A. barreirensis - B17 & 0,00 & 0,00 & 0,00 & 0,00 & 0,00 & 0,00 & 0,00 & 0,00 & & & & & & & & & & \\
\hline 10 & A. eichleri-E17 & 0,00 & 0,00 & 0,00 & 0,00 & 0,00 & 0,00 & 0,00 & 0,00 & 0,00 & & & & & & & & & \\
\hline 11 & A. eichleri- E18 & 0,00 & 0,00 & 0,00 & 0,00 & 0,00 & 0,00 & 0,00 & 0,00 & 0,00 & 0,00 & & & & & & & & \\
\hline 12 & A. eichleri-E19 & 0,00 & 0,00 & 0,00 & 0,00 & 0,00 & 0,00 & 0,00 & 0,00 & 0,00 & 0,00 & 0,00 & & & & & & & \\
\hline 13 & A. funifera -7 & 0,00 & 0,00 & 0,00 & 0,00 & 0,00 & 0,00 & 0,00 & 0,00 & 0,00 & 0,01 & 0,00 & 0,00 & & & & & & \\
\hline 14 & A. maripa -10 & 0,00 & 0,00 & 0,00 & 0,00 & 0,00 & 0,00 & 0,00 & 0,00 & 0,00 & 0,00 & 0,00 & 0,00 & 0,00 & & & & & \\
\hline 15 & A. maripa -15 & 0,00 & 0,00 & 0,00 & 0,00 & 0,00 & 0,00 & 0,00 & 0,00 & 0,00 & 0,00 & 0,00 & 0,00 & 0,00 & 0,00 & & & & \\
\hline 16 & A. phalerata-P12 & 0,00 & 0,00 & 0,00 & 0,00 & 0,00 & 0,00 & 0,00 & 0,00 & 0,00 & 0,00 & 0,00 & 0,00 & 0,00 & 0,00 & 0,00 & & & \\
\hline 17 & A. phalerata-P30 & 0,00 & 0,00 & 0,00 & 0,00 & 0,00 & 0,00 & 0,00 & 0,00 & 0,00 & 0,00 & 0,00 & 0,00 & 0,00 & 0,00 & 0,00 & 0,00 & & \\
\hline 18 & A. phalerata-P36 & 0,00 & 0,00 & 0,00 & 0,00 & 0,00 & 0,00 & 0,00 & 0,00 & 0,00 & 0,00 & 0,00 & 0,00 & 0,00 & 0,00 & 0,00 & 0,00 & 0,00 & \\
\hline 19 & A. speciosa - S5 & 0,00 & 0,00 & 0,00 & 0,00 & 0,00 & 0,00 & 0,00 & 0,00 & 0,00 & 0,00 & 0,00 & 0,00 & 0,00 & 0,00 & 0,00 & 0,00 & 0,00 & 0,00 \\
\hline 20 & A. speciosa-\$4 & 0,00 & 0,00 & 0,00 & 0,00 & 0,00 & 0,00 & 0,00 & 0,00 & 0,00 & 0,00 & 0,00 & 0,00 & 0,00 & 0,00 & 0,00 & 0,00 & 0,00 & 0,00 \\
\hline 21 & A. allenii - AJ404829.1 & 0,00 & 0,00 & 0,00 & 0,00 & 0,00 & 0,00 & 0,00 & 0,00 & 0,00 & 0,00 & 0,00 & 0,00 & 0,00 & 0,00 & 0,00 & 0,00 & 0,00 & 0,00 \\
\hline 22 & A. butyracea - JQ590420.1 & 0,00 & 0,00 & 0,00 & 0,00 & 0,00 & 0,00 & 0,00 & 0,00 & 0,00 & 0,00 & 0,00 & 0,00 & 0,00 & 0,00 & 0,00 & 0,00 & 0,00 & 0,00 \\
\hline 23 & A. rostrata - GQ981675.1 & 0,00 & 0,00 & 0,00 & 0,00 & 0,00 & 0,00 & 0,00 & 0,00 & 0,00 & 0,00 & 0,00 & 0,00 & 0,00 & 0,00 & 0,00 & 0,00 & 0,00 & 0,00 \\
\hline 24 & A. teixeirana - híb - BA1 & 0,00 & 0,00 & 0,00 & 0,00 & 0,00 & 0,00 & 0,00 & 0,00 & 0,00 & 0,00 & 0,00 & 0,00 & 0,00 & 0,00 & 0,00 & 0,00 & 0,00 & 0,00 \\
\hline 25 & A. teixeirana - híb - BA4 & 0,00 & 0,00 & 0,00 & 0,00 & 0,00 & 0,00 & 0,00 & 0,00 & 0,00 & 0,00 & 0,00 & 0,00 & 0,00 & 0,00 & 0,00 & 0,00 & 0,00 & 0,00 \\
\hline 26 & A. teixeirana - híb - BA39 & 0,00 & 0,00 & 0,00 & 0,00 & 0,00 & 0,00 & 0,00 & 0,00 & 0,00 & 0,01 & 0,00 & 0,00 & 0,00 & 0,00 & 0,00 & 0,00 & 0,00 & 0,00 \\
\hline 27 & A. teixeirana - híb-CT01 & 0,00 & 0,00 & 0,00 & 0,00 & 0,00 & 0,00 & 0,00 & 0,00 & 0,00 & 0,00 & 0,00 & 0,00 & 0,00 & 0,00 & 0,00 & 0,00 & 0,00 & 0,00 \\
\hline 28 & A. teixeirana - híb - СТ02 & 0,00 & 0,00 & 0,00 & 0,00 & 0,00 & 0,00 & 0,00 & 0,00 & 0,00 & 0,00 & 0,00 & 0,00 & 0,00 & 0,00 & 0,00 & 0,00 & 0,00 & 0,00 \\
\hline 29 & A. teixeirana - híb-CT20 & 0,00 & 0,00 & 0,00 & 0,00 & 0,00 & 0,00 & 0,00 & 0,00 & 0,00 & 0,00 & 0,00 & 0,00 & 0,00 & 0,00 & 0,00 & 0,00 & 0,00 & 0,00 \\
\hline 30 & A. teixeirana - híb-CT37 & 0,00 & 0,00 & 0,00 & 0,00 & 0,00 & 0,00 & 0,00 & 0,00 & 0,00 & 0,00 & 0,00 & 0,00 & 0,00 & 0,00 & 0,00 & 0,00 & 0,00 & 0,00 \\
\hline 31 & A. teixeirana - híb-CT22 & 0,00 & 0,00 & 0,00 & 0,00 & 0,00 & 0,00 & 0,00 & 0,00 & 0,00 & 0,00 & 0,00 & 0,00 & 0,00 & 0,00 & 0,00 & 0,00 & 0,00 & 0,00 \\
\hline 32 & A. teixeirana - híb-CT38 & 0,00 & 0,00 & 0,00 & 0,00 & 0,00 & 0,00 & 0,00 & 0,00 & 0,00 & 0,00 & 0,00 & 0,00 & 0,00 & 0,00 & 0,00 & 0,00 & 0,00 & 0,00 \\
\hline 33 & A. speciosa - CT47 & 0,00 & 0,00 & 0,00 & 0,00 & 0,00 & 0,00 & 0,00 & 0,00 & 0,00 & 0,00 & 0,00 & 0,00 & 0,00 & 0,00 & 0,00 & 0,00 & 0,00 & 0,00 \\
\hline 34 & A. eichleri-ES22 & 0,00 & 0,00 & 0,00 & 0,00 & 0,00 & 0,00 & 0,00 & 0,00 & 0,00 & 0,01 & 0,00 & 0,00 & 0,00 & 0,00 & 0,00 & 0,00 & 0,00 & 0,00 \\
\hline 35 & Cocos nucifera - AY012507.1 & 0,00 & 0,00 & 0,00 & 0,00 & 0,00 & 0,00 & 0,00 & 0,00 & 0,00 & 0,00 & 0,00 & 0,00 & 0,00 & 0,00 & 0,00 & 0,00 & 0,00 & 0,00 \\
\hline
\end{tabular}


Continuação da Tabela 17. Estimativas de distâncias par a par entre as sequências de Attalea geradas para o marcador rbcL (Kimura 2P)

\begin{tabular}{|c|c|c|c|c|c|c|c|c|c|c|c|c|c|c|c|c|c|c|}
\hline & & 19 & 20 & 21 & 22 & 23 & 24 & 25 & 26 & 27 & 28 & 29 & 30 & 31 & 32 & 33 & 34 & 35 \\
\hline 1 & A. eichleri-UB1091 & & & & & & & & & & & & & & & & & \\
\hline 2 & A. phalerata - UB238 & & & & & & & & & & & & & & & & & \\
\hline 3 & A. speciosa - UB10110 & & & & & & & & & & & & & & & & & \\
\hline 4 & A. barreirensis - UB36868 & & & & & & & & & & & & & & & & & \\
\hline 5 & A. speciosa - CEN58039 & & & & & & & & & & & & & & & & & \\
\hline 6 & A. maripa - CEN12546 & & & & & & & & & & & & & & & & & \\
\hline 7 & A. barreirensis - B15 & & & & & & & & & & & & & & & & & \\
\hline 8 & A. barreirensis - B16 & & & & & & & & & & & & & & & & & \\
\hline 9 & A. barreirensis - B17 & & & & & & & & & & & & & & & & & \\
\hline 10 & A. eichleri-E17 & & & & & & & & & & & & & & & & & \\
\hline 11 & A. eichleri-E18 & & & & & & & & & & & & & & & & & \\
\hline 12 & A. eichleri-E19 & & & & & & & & & & & & & & & & & \\
\hline 13 & A. funifera -7 & & & & & & & & & & & & & & & & & \\
\hline 14 & A. maripa -10 & & & & & & & & & & & & & & & & & \\
\hline 15 & A. maripa -15 & & & & & & & & & & & & & & & & & \\
\hline 16 & A. phalerata-P12 & & & & & & & & & & & & & & & & & \\
\hline 17 & A. phalerata- $\mathrm{P} 30$ & & & & & & & & & & & & & & & & & \\
\hline 18 & A. phalerata-P36 & & & & & & & & & & & & & & & & & \\
\hline 19 & A. speciosa-S5 & & & & & & & & & & & & & & & & & \\
\hline 20 & A. speciosa-S4 & 0,00 & & & & & & & & & & & & & & & & \\
\hline 21 & A. allenii - AJ404829.1 & 0,00 & 0,00 & & & & & & & & & & & & & & & \\
\hline 22 & A. butyracea - JQ590420.1 & 0,00 & 0,00 & 0,00 & & & & & & & & & & & & & & \\
\hline 23 & A. rostrata - GQ981675.1 & 0,00 & 0,00 & 0,00 & 0,00 & & & & & & & & & & & & & \\
\hline 24 & A. teixeirana - híb - BA1 & 0,00 & 0,00 & 0,00 & 0,00 & 0,00 & & & & & & & & & & & & \\
\hline 25 & A. teixeirana - híb-BA4 & 0,00 & 0,00 & 0,00 & 0,00 & 0,00 & 0,00 & & & & & & & & & & & \\
\hline 26 & A. teixeirana - híb-BA39 & 0,00 & 0,00 & 0,00 & 0,00 & 0,00 & 0,00 & 0,00 & & & & & & & & & & \\
\hline 27 & A. teixeirana - híb-CT01 & 0,00 & 0,00 & 0,00 & 0,00 & 0,00 & 0,00 & 0,00 & 0,00 & & & & & & & & & \\
\hline 28 & A. teixeirana - híb-CT02 & 0,00 & 0,00 & 0,00 & 0,00 & 0,00 & 0,00 & 0,00 & 0,00 & 0,00 & & & & & & & & \\
\hline 29 & A. teixeirana - híb-CT20 & 0,00 & 0,00 & 0,00 & 0,00 & 0,00 & 0,00 & 0,00 & 0,00 & 0,00 & 0,00 & & & & & & & \\
\hline 30 & A. teixeirana - híb-CT37 & 0,00 & 0,00 & 0,00 & 0,00 & 0,00 & 0,00 & 0,00 & 0,00 & 0,00 & 0,00 & 0,00 & & & & & & \\
\hline 31 & A. teixeirana - híb-CT22 & 0,00 & 0,00 & 0,00 & 0,00 & 0,00 & 0,00 & 0,00 & 0,00 & 0,00 & 0,00 & 0,00 & 0,00 & & & & & \\
\hline 32 & A. teixeirana - híb-CT38 & 0,00 & 0,00 & 0,00 & 0,00 & 0,00 & 0,00 & 0,00 & 0,00 & 0,00 & 0,00 & 0,00 & 0,00 & 0,00 & & & & \\
\hline 33 & A. speciosa - CT47 & 0,00 & 0,00 & 0,00 & 0,00 & 0,00 & 0,00 & 0,00 & 0,00 & 0,00 & 0,00 & 0,00 & 0,00 & 0,00 & 0,00 & & & \\
\hline 34 & A. eichleri-ES22 & 0,00 & 0,00 & 0,00 & 0,00 & 0,00 & 0,00 & 0,00 & 0,00 & 0,00 & 0,00 & 0,00 & 0,00 & 0,00 & 0,00 & 0,00 & & \\
\hline 35 & Cocos nucifera - AY012507.1 & 0,00 & 0,00 & 0,00 & 0,00 & 0,00 & 0,00 & 0,00 & 0,00 & 0,00 & 0,00 & 0,01 & 0,00 & 0,00 & 0,00 & 0,00 & 0,00 & \\
\hline
\end{tabular}


Tabela 18. Estimativa de distâncias par a par entre as sequências de Attalea geradas para o marcador matK (Kimura 2P)

\begin{tabular}{|c|c|c|c|c|c|c|c|c|c|c|c|c|c|c|c|c|c|c|c|}
\hline & & 1 & 2 & 3 & 4 & 5 & 6 & 7 & 8 & 9 & 10 & 11 & 12 & 13 & 14 & 15 & 16 & 17 & 18 \\
\hline 1 & A. eichleri-UB1091 & & & & & & & & & & & & & & & & & & \\
\hline 2 & A. phalerata - UB238 & 0,00 & & & & & & & & & & & & & & & & & \\
\hline 3 & A. speciosa - UB10110 & 0,00 & 0,00 & & & & & & & & & & & & & & & & \\
\hline 4 & A. vitrivir - CEN10759 & 0,00 & 0,00 & 0,00 & & & & & & & & & & & & & & & \\
\hline 5 & A. barreirensis - B15 & 0,00 & 0,00 & 0,00 & 0,00 & & & & & & & & & & & & & & \\
\hline 6 & A. barreirensis - B16 & 0,00 & 0,00 & 0,00 & 0,00 & 0,00 & & & & & & & & & & & & & \\
\hline 7 & A. barreirensis - B17 & 0,00 & 0,01 & 0,01 & 0,00 & 0,00 & 0,00 & & & & & & & & & & & & \\
\hline 8 & A. eichleri-E18 & 0,00 & 0,00 & 0,00 & 0,00 & 0,00 & 0,00 & 0,00 & & & & & & & & & & & \\
\hline 9 & A. eichleri- E19 & 0,00 & 0,00 & 0,00 & 0,00 & 0,00 & 0,00 & 0,00 & 0,00 & & & & & & & & & & \\
\hline 10 & A. funifera -7 & 0,00 & 0,00 & 0,00 & 0,00 & 0,00 & 0,00 & 0,00 & 0,00 & 0,00 & & & & & & & & & \\
\hline 11 & A. funifera -10 & 0,00 & 0,00 & 0,00 & 0,00 & 0,00 & 0,00 & 0,00 & 0,00 & 0,00 & 0,00 & & & & & & & & \\
\hline 12 & A. funifera -25 & 0,00 & 0,00 & 0,00 & 0,00 & 0,00 & 0,00 & 0,00 & 0,00 & 0,00 & 0,00 & 0,00 & & & & & & & \\
\hline 13 & A. maripa -10 & 0,00 & 0,00 & 0,00 & 0,00 & 0,00 & 0,00 & 0,00 & 0,00 & 0,00 & 0,00 & 0,00 & 0,00 & & & & & & \\
\hline 14 & A. maripa -15 & 0,00 & 0,00 & 0,00 & 0,00 & 0,00 & 0,00 & 0,00 & 0,00 & 0,00 & 0,00 & 0,00 & 0,00 & 0,00 & & & & & \\
\hline 15 & A. maripa -16 & 0,00 & 0,00 & 0,00 & 0,00 & 0,00 & 0,00 & 0,00 & 0,00 & 0,00 & 0,00 & 0,00 & 0,00 & 0,00 & 0,00 & & & & \\
\hline 16 & A. phalerata- $\mathrm{P} 30$ & 0,00 & 0,00 & 0,00 & 0,00 & 0,00 & 0,00 & 0,01 & 0,00 & 0,00 & 0,00 & 0,00 & 0,00 & 0,00 & 0,00 & 0,00 & & & \\
\hline 17 & A. phalerata-P36 & 0,00 & 0,00 & 0,00 & 0,00 & 0,00 & 0,00 & 0,00 & 0,00 & 0,00 & 0,00 & 0,00 & 0,00 & 0,00 & 0,00 & 0,00 & 0,00 & & \\
\hline 18 & A. speciosa - \$4 & 0,00 & 0,00 & 0,00 & 0,00 & 0,00 & 0,00 & 0,00 & 0,00 & 0,00 & 0,00 & 0,00 & 0,00 & 0,00 & 0,00 & 0,00 & 0,00 & 0,00 & \\
\hline 19 & A. speciosa - $\mathrm{S} 17$ & 0,00 & 0,00 & 0,00 & 0,00 & 0,00 & 0,00 & 0,00 & 0,00 & 0,00 & 0,00 & 0,00 & 0,00 & 0,00 & 0,00 & 0,00 & 0,00 & 0,00 & 0,00 \\
\hline 20 & A. phalerata-HQ265548.1 & 0,00 & 0,00 & 0,00 & 0,00 & 0,00 & 0,00 & 0,01 & 0,00 & 0,00 & 0,00 & 0,00 & 0,00 & 0,00 & 0,00 & 0,00 & 0,00 & 0,00 & 0,00 \\
\hline 21 & A. butyracea - JQ586691.1 & 0,00 & 0,00 & 0,00 & 0,00 & 0,00 & 0,00 & 0,01 & 0,00 & 0,00 & 0,00 & 0,00 & 0,00 & 0,00 & 0,00 & 0,00 & 0,00 & 0,00 & 0,00 \\
\hline 22 & A. rostrata - GQ981943.1 & 0,00 & 0,00 & 0,00 & 0,00 & 0,00 & 0,00 & 0,01 & 0,00 & 0,00 & 0,00 & 0,00 & 0,00 & 0,00 & 0,00 & 0,00 & 0,00 & 0,00 & 0,00 \\
\hline 23 & A. butyracea - JQ586691.1 & 0,00 & 0,00 & 0,00 & 0,00 & 0,00 & 0,00 & 0,01 & 0,00 & 0,00 & 0,00 & 0,00 & 0,00 & 0,00 & 0,00 & 0,00 & 0,00 & 0,00 & 0,00 \\
\hline 24 & A. allenii-AM114636.1 & 0,00 & 0,00 & 0,00 & 0,00 & 0,00 & 0,00 & 0,01 & 0,00 & 0,00 & 0,00 & 0,00 & 0,00 & 0,00 & 0,00 & 0,00 & 0,00 & 0,00 & 0,00 \\
\hline 25 & A. teixeirana - híb-BA1 & 0,00 & 0,00 & 0,00 & 0,00 & 0,00 & 0,00 & 0,01 & 0,00 & 0,00 & 0,00 & 0,00 & 0,00 & 0,00 & 0,00 & 0,00 & 0,00 & 0,00 & 0,00 \\
\hline 26 & A. teixeirana - híb-BA39 & 0,00 & 0,00 & 0,00 & 0,00 & 0,00 & 0,00 & 0,01 & 0,00 & 0,00 & 0,00 & 0,00 & 0,00 & 0,00 & 0,00 & 0,00 & 0,00 & 0,00 & 0,00 \\
\hline 27 & A. teixeirana - híb-CT01 & 0,00 & 0,00 & 0,00 & 0,00 & 0,00 & 0,00 & 0,01 & 0,00 & 0,00 & 0,00 & 0,00 & 0,00 & 0,00 & 0,00 & 0,00 & 0,00 & 0,00 & 0,00 \\
\hline 28 & A. teixeirana - híb-CT02 & 0,00 & 0,00 & 0,00 & 0,00 & 0,00 & 0,00 & 0,01 & 0,00 & 0,00 & 0,00 & 0,00 & 0,00 & 0,00 & 0,00 & 0,00 & 0,00 & 0,00 & 0,00 \\
\hline 29 & A. teixeirana - híb - СТ22 & 0,00 & 0,00 & 0,00 & 0,00 & 0,00 & 0,00 & 0,01 & 0,00 & 0,00 & 0,00 & 0,00 & 0,00 & 0,00 & 0,00 & 0,00 & 0,00 & 0,00 & 0,00 \\
\hline 30 & A. teixeirana - híb - СТ37 & 0,00 & 0,00 & 0,00 & 0,00 & 0,00 & 0,00 & 0,01 & 0,00 & 0,00 & 0,00 & 0,00 & 0,00 & 0,00 & 0,00 & 0,00 & 0,00 & 0,00 & 0,00 \\
\hline 31 & A. teixeirana - híb - СТ38 & 0,00 & 0,00 & 0,00 & 0,00 & 0,00 & 0,00 & 0,01 & 0,00 & 0,00 & 0,00 & 0,00 & 0,00 & 0,00 & 0,00 & 0,00 & 0,00 & 0,00 & 0,00 \\
\hline 32 & A. speciosa - CT46 & 0,00 & 0,00 & 0,00 & 0,00 & 0,00 & 0,00 & 0,01 & 0,00 & 0,00 & 0,00 & 0,00 & 0,00 & 0,00 & 0,00 & 0,00 & 0,00 & 0,00 & 0,00 \\
\hline 33 & A. speciosa - CT47 & 0,00 & 0,00 & 0,00 & 0,00 & 0,00 & 0,00 & 0,01 & 0,00 & 0,00 & 0,00 & 0,00 & 0,00 & 0,00 & 0,00 & 0,00 & 0,00 & 0,00 & 0,00 \\
\hline 34 & A. teixeirana - híb-LA19 & 0,00 & 0,00 & 0,00 & 0,00 & 0,00 & 0,00 & 0,01 & 0,00 & 0,00 & 0,00 & 0,00 & 0,00 & 0,00 & 0,00 & 0,00 & 0,00 & 0,00 & 0,00 \\
\hline 35 & Cocos nucifera - HQ265564.1 & 0,01 & 0,00 & 0,00 & 0,01 & 0,01 & 0,01 & 0,01 & 0,01 & 0,01 & 0,01 & 0,01 & 0,01 & 0,01 & 0,01 & 0,01 & 0,01 & 0,01 & 0,01 \\
\hline
\end{tabular}


Continuação da Tabela 18. Estimativa de distâncias par a par entre as sequências de Attalea geradas para o marcador matK (Kimura 2P)

\begin{tabular}{|c|c|c|c|c|c|c|c|c|c|c|c|c|c|c|c|c|c|c|}
\hline & & 19 & 20 & 21 & 22 & 23 & 24 & 25 & 26 & 27 & 28 & 29 & 30 & 31 & 32 & 33 & 34 & 35 \\
\hline 1 & A. eichleri-UB1091 & & & & & & & & & & & & & & & & & \\
\hline 2 & A. phalerata - UB238 & & & & & & & & & & & & & & & & & \\
\hline 3 & A. speciosa - UB10110 & & & & & & & & & & & & & & & & & \\
\hline 4 & A. vitrivir - CEN10759 & & & & & & & & & & & & & & & & & \\
\hline 5 & A. barreirensis - B15 & & & & & & & & & & & & & & & & & \\
\hline 6 & A. barreirensis - B16 & & & & & & & & & & & & & & & & & \\
\hline 7 & A. barreirensis - B17 & & & & & & & & & & & & & & & & & \\
\hline 8 & A. eichleri-E18 & & & & & & & & & & & & & & & & & \\
\hline 9 & A. eichleri-E19 & & & & & & & & & & & & & & & & & \\
\hline 10 & A. funifera -7 & & & & & & & & & & & & & & & & & \\
\hline 11 & A. funifera - 10 & & & & & & & & & & & & & & & & & \\
\hline 12 & A. funifera -25 & & & & & & & & & & & & & & & & & \\
\hline 13 & A. maripa -10 & & & & & & & & & & & & & & & & & \\
\hline 14 & A. maripa -15 & & & & & & & & & & & & & & & & & \\
\hline 15 & A. maripa -16 & & & & & & & & & & & & & & & & & \\
\hline 16 & A. phalerata-P30 & & & & & & & & & & & & & & & & & \\
\hline 17 & A. phalerata-P36 & & & & & & & & & & & & & & & & & \\
\hline 18 & A. speciosa - S4 & & & & & & & & & & & & & & & & & \\
\hline 19 & A. speciosa - S17 & & & & & & & & & & & & & & & & & \\
\hline 20 & A. phalerata - HQ265548.1 & 0,00 & & & & & & & & & & & & & & & & \\
\hline 21 & A. butyracea - JQ586691.1 & 0,00 & 0,00 & & & & & & & & & & & & & & & \\
\hline 22 & A. rostrata - GQ981943.1 & 0,00 & 0,00 & 0,00 & & & & & & & & & & & & & & \\
\hline 23 & A. butyracea - JQ586691.1 & 0,00 & 0,00 & 0,00 & 0,00 & & & & & & & & & & & & & \\
\hline 24 & A. allenii - AM114636.1 & 0,00 & 0,00 & 0,00 & 0,00 & 0,00 & & & & & & & & & & & & \\
\hline 25 & A. teixeirana - híb - BA1 & 0,00 & 0,00 & 0,00 & 0,00 & 0,00 & 0,00 & & & & & & & & & & & \\
\hline 26 & A. teixeirana - híb - BA39 & 0,00 & 0,00 & 0,00 & 0,00 & 0,00 & 0,00 & 0,00 & & & & & & & & & & \\
\hline 27 & A. teixeirana - híb-CT01 & 0,00 & 0,00 & 0,00 & 0,00 & 0,00 & 0,00 & 0,00 & 0,00 & & & & & & & & & \\
\hline 28 & A. teixeirana - híb - СТ02 & 0,00 & 0,00 & 0,00 & 0,00 & 0,00 & 0,00 & 0,00 & 0,00 & 0,00 & & & & & & & & \\
\hline 29 & A. teixeirana - híb - CT22 & 0,00 & 0,00 & 0,00 & 0,00 & 0,00 & 0,00 & 0,00 & 0,00 & 0,00 & 0,00 & & & & & & & \\
\hline 30 & A. teixeirana - híb - СТ37 & 0,00 & 0,00 & 0,00 & 0,00 & 0,00 & 0,00 & 0,00 & 0,00 & 0,00 & 0,00 & 0,00 & & & & & & \\
\hline 31 & A. teixeirana - híb - CT38 & 0,00 & 0,00 & 0,00 & 0,00 & 0,00 & 0,00 & 0,00 & 0,00 & 0,00 & 0,00 & 0,00 & 0,00 & & & & & \\
\hline 32 & A. speciosa - CТ46 & 0,00 & 0,00 & 0,00 & 0,00 & 0,00 & 0,00 & 0,00 & 0,00 & 0,00 & 0,00 & 0,00 & 0,00 & 0,00 & & & & \\
\hline 33 & A. speciosa - CT47 & 0,00 & 0,00 & 0,00 & 0,00 & 0,00 & 0,00 & 0,00 & 0,00 & 0,00 & 0,00 & 0,00 & 0,00 & 0,00 & 0,00 & & & \\
\hline 34 & A. teixeirana - híb - LA19 & 0,00 & 0,00 & 0,00 & 0,00 & 0,00 & 0,00 & 0,00 & 0,00 & 0,00 & 0,00 & 0,00 & 0,00 & 0,00 & 0,00 & 0,00 & & \\
\hline 35 & Cocos nucifera - HQ265564.1 & 0,01 & 0,00 & 0,00 & 0,00 & 0,00 & 0,00 & 0,00 & 0,00 & 0,00 & 0,00 & 0,01 & 0,00 & 0,00 & 0,00 & 0,00 & 0,00 & \\
\hline
\end{tabular}


Tabela19. Estimativa de distâncias par a par entre as sequências de Attalea geradas para o marcador trnL (Kimura 2P)

\begin{tabular}{|c|c|c|c|c|c|c|c|c|c|c|c|c|c|c|c|c|}
\hline & & 1 & 2 & 3 & 4 & 5 & 6 & 7 & 8 & 9 & 10 & 11 & 12 & 13 & 14 & 15 \\
\hline 1 & A. barreirensis - B15 & & & & & & & & & & & & & & & \\
\hline 2 & A. barreirensis - B16 & 0,00 & & & & & & & & & & & & & & \\
\hline 3 & A. eichleri-E18 & 0,00 & 0,00 & & & & & & & & & & & & & \\
\hline 4 & A. eichleri-E19 & 0,00 & 0,00 & 0,00 & & & & & & & & & & & & \\
\hline 5 & A. maripa - 15 & 0,00 & 0,00 & 0,00 & 0,00 & & & & & & & & & & & \\
\hline 6 & A. phalerata-P12 & 0,00 & 0,00 & 0,00 & 0,00 & 0,00 & & & & & & & & & & \\
\hline 7 & A. phalerata- $\mathrm{P} 30$ & 0,00 & 0,00 & 0,00 & 0,00 & 0,00 & 0,00 & & & & & & & & & \\
\hline 8 & A. phalerata-P36 & 0,00 & 0,00 & 0,00 & 0,00 & 0,00 & 0,00 & 0,00 & & & & & & & & \\
\hline 9 & A. speciosa- $\mathrm{S} 4$ & 0,00 & 0,00 & 0,00 & 0,00 & 0,00 & 0,00 & 0,00 & 0,00 & & & & & & & \\
\hline 10 & A. speciosa - S5 & 0,00 & 0,00 & 0,00 & 0,00 & 0,00 & 0,00 & 0,00 & 0,00 & 0,00 & & & & & & \\
\hline 11 & A. speciosa - $\mathrm{S} 17$ & 0,00 & 0,00 & 0,00 & 0,00 & 0,00 & 0,00 & 0,00 & 0,00 & 0,00 & 0,00 & & & & & \\
\hline 12 & A. barreirensis - UB36868 & 0,00 & 0,00 & 0,00 & 0,00 & 0,00 & 0,00 & 0,00 & 0,00 & 0,00 & 0,00 & 0,00 & & & & \\
\hline 13 & A. barreirensis - CEN52072 & 0,00 & 0,00 & 0,00 & 0,00 & 0,00 & 0,00 & 0,00 & 0,00 & 0,00 & 0,00 & 0,00 & 0,00 & & & \\
\hline 14 & A. eichleri - UB1091 & 0,00 & 0,00 & 0,00 & 0,00 & 0,00 & 0,00 & 0,00 & 0,00 & 0,00 & 0,00 & 0,00 & 0,00 & 0,00 & & \\
\hline 15 & A. phalerata - UB238 & 0,00 & 0,00 & 0,00 & 0,00 & 0,00 & 0,00 & 0,00 & 0,00 & 0,00 & 0,00 & 0,00 & 0,00 & 0,00 & 0,00 & \\
\hline 16 & A. speciosa - UB10110 & 0,00 & 0,00 & 0,00 & 0,00 & 0,00 & 0,00 & 0,00 & 0,00 & 0,00 & 0,00 & 0,00 & 0,00 & 0,00 & 0,00 & 0,00 \\
\hline 17 & A. vitrivir-CEN10759 & 0,00 & 0,00 & 0,00 & 0,00 & 0,00 & 0,00 & 0,00 & 0,00 & 0,00 & 0,00 & 0,00 & 0,00 & 0,00 & 0,00 & 0,00 \\
\hline 18 & A. barreirensis - B17 & 0,00 & 0,00 & 0,00 & 0,00 & 0,00 & 0,00 & 0,00 & 0,00 & 0,00 & 0,00 & 0,00 & 0,00 & 0,00 & 0,00 & 0,00 \\
\hline 19 & A. crassispatha - AJ241321.1 & 0,00 & 0,00 & 0,00 & 0,00 & 0,00 & 0,00 & 0,00 & 0,00 & 0,00 & 0,00 & 0,00 & 0,00 & 0,00 & 0,00 & 0,00 \\
\hline 20 & A. phalerata-HQ265783.1 & 0,00 & 0,00 & 0,00 & 0,00 & 0,00 & 0,00 & 0,00 & 0,00 & 0,00 & 0,00 & 0,00 & 0,00 & 0,00 & 0,00 & 0,00 \\
\hline 21 & A. allenii-AJ241312.1 & 0,00 & 0,00 & 0,00 & 0,00 & 0,00 & 0,00 & 0,00 & 0,00 & 0,00 & 0,00 & 0,00 & 0,00 & 0,00 & 0,00 & 0,00 \\
\hline 22 & A. teixeirana - híb-BA1 & 0,00 & 0,00 & 0,00 & 0,00 & 0,00 & 0,00 & 0,00 & 0,00 & 0,00 & 0,00 & 0,00 & 0,00 & 0,00 & 0,00 & 0,00 \\
\hline 23 & A. teixeirana - híb - СТ01 & 0,00 & 0,00 & 0,00 & 0,00 & 0,00 & 0,00 & 0,00 & 0,00 & 0,00 & 0,00 & 0,00 & 0,00 & 0,00 & 0,00 & 0,00 \\
\hline 24 & A. teixeirana - híb-CT02 & 0,00 & 0,00 & 0,00 & 0,00 & 0,00 & 0,00 & 0,00 & 0,00 & 0,00 & 0,00 & 0,00 & 0,00 & 0,00 & 0,00 & 0,00 \\
\hline 25 & A. eichleri-híb-CT07 & 0,00 & 0,00 & 0,00 & 0,00 & 0,00 & 0,00 & 0,00 & 0,00 & 0,00 & 0,00 & 0,00 & 0,00 & 0,00 & 0,00 & 0,00 \\
\hline 26 & A. teixeirana - híb-CT20 & 0,00 & 0,00 & 0,00 & 0,00 & 0,00 & 0,00 & 0,00 & 0,00 & 0,00 & 0,00 & 0,00 & 0,00 & 0,00 & 0,00 & 0,00 \\
\hline 27 & A. teixeirana - híb-CT22 & 0,00 & 0,00 & 0,00 & 0,00 & 0,00 & 0,00 & 0,00 & 0,00 & 0,00 & 0,00 & 0,00 & 0,00 & 0,00 & 0,00 & 0,00 \\
\hline 28 & A. teixeirana - híb-CT37 & 0,00 & 0,00 & 0,00 & 0,00 & 0,00 & 0,00 & 0,00 & 0,00 & 0,00 & 0,00 & 0,00 & 0,00 & 0,00 & 0,00 & 0,00 \\
\hline 29 & A. speciosa - híb-CT46 & 0,00 & 0,00 & 0,00 & 0,00 & 0,00 & 0,00 & 0,00 & 0,00 & 0,00 & 0,00 & 0,00 & 0,00 & 0,00 & 0,00 & 0,00 \\
\hline 30 & A. speciosa - híb-CT47 & 0,00 & 0,00 & 0,00 & 0,00 & 0,00 & 0,00 & 0,00 & 0,00 & 0,00 & 0,00 & 0,00 & 0,00 & 0,00 & 0,00 & 0,00 \\
\hline 31 & Cocos nucifera - AM113647.1 & 0,01 & 0,01 & 0,01 & 0,01 & 0,01 & 0,01 & 0,01 & 0,01 & 0,01 & 0,01 & 0,01 & 0,01 & 0,01 & 0,01 & 0,01 \\
\hline
\end{tabular}


Continuação da Tabela 19. Estimativa de distâncias par a par entre as sequências de Attalea geradas para o marcador trnL (Kimura 2P)

\begin{tabular}{|c|c|c|c|c|c|c|c|c|c|c|c|c|c|c|c|c|c|}
\hline & & 16 & 17 & 18 & 19 & 20 & 21 & 22 & 23 & 24 & 25 & 26 & 27 & 28 & 29 & 30 & 31 \\
\hline 1 & A. barreirensis - B15 & & & & & & & & & & & & & & & & \\
\hline 2 & A. barreirensis - B16 & & & & & & & & & & & & & & & & \\
\hline 3 & A. eichleri-E18 & & & & & & & & & & & & & & & & \\
\hline 4 & A. eichleri-E19 & & & & & & & & & & & & & & & & \\
\hline 5 & A. maripa -15 & & & & & & & & & & & & & & & & \\
\hline 6 & A. phalerata-P12 & & & & & & & & & & & & & & & & \\
\hline 7 & A. phalerata-P30 & & & & & & & & & & & & & & & & \\
\hline 8 & A. phalerata-P36 & & & & & & & & & & & & & & & & \\
\hline 9 & A. speciosa - $\mathrm{S} 4$ & & & & & & & & & & & & & & & & \\
\hline 10 & A. speciosa - S5 & & & & & & & & & & & & & & & & \\
\hline 11 & A. speciosa - S17 & & & & & & & & & & & & & & & & \\
\hline 12 & A. barreirensis - UB36868 & & & & & & & & & & & & & & & & \\
\hline 13 & A. barreirensis - CEN52072 & & & & & & & & & & & & & & & & \\
\hline 14 & A. eichleri-UB1091 & & & & & & & & & & & & & & & & \\
\hline 15 & A. phalerata - UB238 & & & & & & & & & & & & & & & & \\
\hline 16 & A. speciosa - UB10110 & & & & & & & & & & & & & & & & \\
\hline 17 & A. vitrivir - CEN10759 & 0,00 & & & & & & & & & & & & & & & \\
\hline 18 & A. barreirensis - B17 & 0,00 & 0,00 & & & & & & & & & & & & & & \\
\hline 19 & A. crassispatha - AJ241321.1 & 0,00 & 0,00 & 0,00 & & & & & & & & & & & & & \\
\hline 20 & A. phalerata-HQ265783.1 & 0,00 & 0,00 & 0,00 & 0,00 & & & & & & & & & & & & \\
\hline 21 & A. allenii - AJ241312.1 & 0,00 & 0,00 & 0,00 & 0,00 & 0,00 & & & & & & & & & & & \\
\hline 22 & A. teixeirana - híb - BA1 & 0,00 & 0,00 & 0,00 & 0,00 & 0,00 & 0,00 & & & & & & & & & & \\
\hline 23 & A. teixeirana - híb - СТ01 & 0,00 & 0,00 & 0,00 & 0,00 & 0,00 & 0,00 & 0,00 & & & & & & & & & \\
\hline 24 & A. teixeirana - híb-СT02 & 0,00 & 0,00 & 0,00 & 0,00 & 0,00 & 0,00 & 0,00 & 0,00 & & & & & & & & \\
\hline 25 & A. eichleri- híb-CT07 & 0,00 & 0,00 & 0,00 & 0,00 & 0,00 & 0,00 & 0,00 & 0,00 & 0,00 & & & & & & & \\
\hline 26 & A. teixeirana - híb-CT20 & 0,00 & 0,00 & 0,00 & 0,00 & 0,00 & 0,00 & 0,00 & 0,00 & 0,00 & 0,00 & & & & & & \\
\hline 27 & A. teixeirana - híb - CT22 & 0,00 & 0,00 & 0,00 & 0,00 & 0,00 & 0,00 & 0,00 & 0,00 & 0,00 & 0,00 & 0,00 & & & & & \\
\hline 28 & A. teixeirana - híb - СТ37 & 0,00 & 0,00 & 0,00 & 0,00 & 0,00 & 0,00 & 0,00 & 0,00 & 0,00 & 0,00 & 0,00 & 0,00 & & & & \\
\hline 29 & A. speciosa - híb-CT46 & 0,00 & 0,00 & 0,00 & 0,00 & 0,00 & 0,00 & 0,00 & 0,00 & 0,00 & 0,00 & 0,00 & 0,00 & 0,00 & & & \\
\hline 30 & A. speciosa - híb-CT47 & 0,00 & 0,00 & 0,00 & 0,00 & 0,00 & 0,00 & 0,00 & 0,00 & 0,00 & 0,00 & 0,00 & 0,00 & 0,00 & 0,00 & & \\
\hline 31 & Cocos nucifera - AM113647.1 & 0,01 & 0,01 & 0,01 & 0,01 & 0,01 & 0,01 & 0,00 & 0,01 & 0,01 & 0,01 & 0,01 & 0,01 & 0,01 & 0,01 & 0,01 & \\
\hline
\end{tabular}


Tabela 20. Estimativa de distâncias par a par entre as sequências de Attalea geradas para o marcador psbA-trnH (Kimura 2P)

\begin{tabular}{|c|c|c|c|c|c|c|c|c|c|c|c|c|c|c|c|c|}
\hline & & 1 & 2 & 3 & 4 & 5 & 6 & 7 & 8 & 9 & 10 & 11 & 12 & 13 & 14 & 15 \\
\hline 1 & A. barreirensis - B16 & & & & & & & & & & & & & & & \\
\hline 2 & A. barreirensis - B17 & 0,00 & & & & & & & & & & & & & & \\
\hline 3 & A. eichleri-E18 & 0,00 & 0,00 & & & & & & & & & & & & & \\
\hline 4 & A. eichleri-E17 & 0,00 & 0,00 & 0,01 & & & & & & & & & & & & \\
\hline 5 & A. funifera -7 & 0,00 & 0,00 & 0,00 & 0,01 & & & & & & & & & & & \\
\hline 6 & A. funifera -15 & 0,01 & 0,00 & 0,01 & 0,01 & 0,00 & & & & & & & & & & \\
\hline 7 & A. maripa -12 & 0,00 & 0,00 & 0,00 & 0,00 & 0,00 & 0,00 & & & & & & & & & \\
\hline 8 & A. speciosa - S4 & 0,00 & 0,00 & 0,00 & 0,00 & 0,00 & 0,00 & 0,00 & & & & & & & & \\
\hline 9 & A. speciosa - S5 & 0,00 & 0,00 & 0,00 & 0,00 & 0,00 & 0,00 & 0,00 & 0,00 & & & & & & & \\
\hline 10 & A. speciosa - S17 & 0,00 & 0,00 & 0,00 & 0,00 & 0,00 & 0,00 & 0,00 & 0,00 & 0,00 & & & & & & \\
\hline 11 & A. phalerata-P12 & 0,00 & 0,00 & 0,00 & 0,01 & 0,00 & 0,00 & 0,00 & 0,00 & 0,00 & 0,00 & & & & & \\
\hline 12 & A. phalerata-P36 & 0,00 & 0,00 & 0,00 & 0,01 & 0,00 & 0,00 & 0,00 & 0,00 & 0,00 & 0,00 & 0,00 & & & & \\
\hline 13 & A. vitrivir - $2 \mathrm{BM}$ & 0,00 & 0,00 & 0,00 & 0,00 & 0,00 & 0,00 & 0,00 & 0,00 & 0,00 & 0,00 & 0,00 & 0,00 & & & \\
\hline 14 & A. vitrivir - $1 \mathrm{BM}$ & 0,00 & 0,00 & 0,00 & 0,00 & 0,00 & 0,00 & 0,00 & 0,00 & 0,00 & 0,00 & 0,00 & 0,00 & 0,00 & & \\
\hline 15 & A. vitrivir - $2 \mathrm{M} 1$ & 0,00 & 0,00 & 0,00 & 0,00 & 0,00 & 0,00 & 0,00 & 0,00 & 0,00 & 0,00 & 0,00 & 0,00 & 0,00 & 0,00 & \\
\hline 16 & A. vitrivir - $1 \mathrm{M} 1$ & 0,00 & 0,00 & 0,00 & 0,00 & 0,00 & 0,00 & 0,00 & 0,00 & 0,00 & 0,00 & 0,00 & 0,00 & 0,00 & 0,00 & 0,00 \\
\hline 17 & A. eichleri - UB1091 & 0,00 & 0,00 & 0,00 & 0,00 & 0,00 & 0,00 & 0,00 & 0,00 & 0,00 & 0,00 & 0,00 & 0,00 & 0,00 & 0,00 & 0,00 \\
\hline 18 & A. vitrivir - CEN10759 & 0,00 & 0,00 & 0,00 & 0,00 & 0,00 & 0,00 & 0,00 & 0,00 & 0,00 & 0,00 & 0,00 & 0,00 & 0,00 & 0,00 & 0,00 \\
\hline 19 & A. phalerata - UB238 & 0,00 & 0,00 & 0,00 & 0,00 & 0,00 & 0,00 & 0,00 & 0,00 & 0,00 & 0,00 & 0,00 & 0,00 & 0,00 & 0,00 & 0,00 \\
\hline 20 & A. speciosa - UB10110 & 0,00 & 0,00 & 0,00 & 0,01 & 0,00 & 0,01 & 0,00 & 0,00 & 0,00 & 0,00 & 0,00 & 0,00 & 0,00 & 0,00 & 0,00 \\
\hline 21 & A. barreirensis - UB36868 & 0,00 & 0,00 & 0,00 & 0,00 & 0,00 & 0,00 & 0,00 & 0,00 & 0,00 & 0,00 & 0,00 & 0,00 & 0,00 & 0,00 & 0,00 \\
\hline 22 & A. teixeirana - híb - BA1 & 0,01 & 0,01 & 0,01 & 0,01 & 0,01 & 0,01 & 0,01 & 0,01 & 0,01 & 0,01 & 0,01 & 0,01 & 0,01 & 0,01 & 0,01 \\
\hline 23 & A. teixeirana - híb - BA4 & 0,00 & 0,00 & 0,00 & 0,01 & 0,00 & 0,01 & 0,00 & 0,00 & 0,00 & 0,00 & 0,00 & 0,00 & 0,00 & 0,00 & 0,00 \\
\hline 24 & A. teixeirana - híb - СТ01 & 0,00 & 0,00 & 0,00 & 0,00 & 0,00 & 0,00 & 0,00 & 0,00 & 0,00 & 0,00 & 0,00 & 0,00 & 0,00 & 0,00 & 0,00 \\
\hline 25 & A. teixeirana - híb - СТ37 & 0,00 & 0,00 & 0,00 & 0,00 & 0,00 & 0,00 & 0,00 & 0,00 & 0,00 & 0,00 & 0,00 & 0,00 & 0,00 & 0,00 & 0,00 \\
\hline 26 & A. speciosa - CT47 & 0,00 & 0,00 & 0,00 & 0,00 & 0,00 & 0,00 & 0,00 & 0,00 & 0,00 & 0,00 & 0,00 & 0,00 & 0,00 & 0,00 & 0,00 \\
\hline 27 & A. teixeirana - híb - FZ12 & 0,01 & 0,00 & 0,01 & 0,01 & 0,01 & 0,01 & 0,00 & 0,00 & 0,00 & 0,00 & 0,01 & 0,01 & 0,00 & 0,00 & 0,00 \\
\hline 28 & A. teixeirana - híb - CTO2 & 0,01 & 0,01 & 0,01 & 0,02 & 0,01 & 0,02 & 0,01 & 0,01 & 0,01 & 0,01 & 0,01 & 0,01 & 0,01 & 0,01 & 0,01 \\
\hline 29 & A. eichleri-СТ07 & 0,01 & 0,00 & 0,01 & 0,01 & 0,01 & 0,01 & 0,00 & 0,00 & 0,00 & 0,00 & 0,01 & 0,01 & 0,00 & 0,00 & 0,00 \\
\hline 30 & A. teixeirana - híb - CT20 & 0,01 & 0,00 & 0,01 & 0,01 & 0,01 & 0,01 & 0,00 & 0,00 & 0,00 & 0,00 & 0,01 & 0,01 & 0,00 & 0,00 & 0,00 \\
\hline 31 & Cocos nucifera - GQ435464.1 & 0,03 & 0,03 & 0,03 & 0,03 & 0,02 & 0,03 & 0,03 & 0,03 & 0,03 & 0,03 & 0,02 & 0,02 & 0,03 & 0,03 & 0,03 \\
\hline
\end{tabular}


Continuação da Tabela 20. Estimativa de distâncias par a par entre as sequências de Attalea geradas para o marcador psbA-trnH (Kimura 2P)

\begin{tabular}{|c|c|c|c|c|c|c|c|c|c|c|c|c|c|c|c|c|c|}
\hline & & 16 & 17 & 18 & 19 & 20 & 21 & 22 & 23 & 24 & 25 & 26 & 27 & 28 & 29 & 30 & 31 \\
\hline 1 & A. barreirensis - B16 & & & & & & & & & & & & & & & & \\
\hline 2 & A. barreirensis - B17 & & & & & & & & & & & & & & & & \\
\hline 3 & A. eichleri-E18 & & & & & & & & & & & & & & & & \\
\hline 4 & A. eichleri-E17 & & & & & & & & & & & & & & & & \\
\hline 5 & A. funifera -7 & & & & & & & & & & & & & & & & \\
\hline 6 & A. funifera -15 & & & & & & & & & & & & & & & & \\
\hline 7 & A. maripa -12 & & & & & & & & & & & & & & & & \\
\hline 8 & A. speciosa - S4 & & & & & & & & & & & & & & & & \\
\hline 9 & A. speciosa - S5 & & & & & & & & & & & & & & & & \\
\hline 10 & A. speciosa - $\mathrm{S} 17$ & & & & & & & & & & & & & & & & \\
\hline 11 & A. phalerata- $\mathrm{P} 12$ & & & & & & & & & & & & & & & & \\
\hline 12 & A. phalerata - P36 & & & & & & & & & & & & & & & & \\
\hline 13 & A. vitrivir - $2 \mathrm{BM}$ & & & & & & & & & & & & & & & & \\
\hline 14 & A. vitrivir - 1BM & & & & & & & & & & & & & & & & \\
\hline 15 & A. vitrivir $-2 \mathrm{M} 1$ & & & & & & & & & & & & & & & & \\
\hline 16 & A. vitrivir - $1 \mathrm{M} 1$ & & & & & & & & & & & & & & & & \\
\hline 17 & A. eichleri - UB1091 & 0,00 & & & & & & & & & & & & & & & \\
\hline 18 & A. vitrivir - CEN10759 & 0,00 & 0,00 & & & & & & & & & & & & & & \\
\hline 19 & A. phalerata - UB238 & 0,00 & 0,00 & 0,00 & & & & & & & & & & & & & \\
\hline 20 & A. speciosa - UB10110 & 0,00 & 0,00 & 0,00 & 0,00 & & & & & & & & & & & & \\
\hline 21 & A. barreirensis - UB36868 & 0,00 & 0,00 & 0,00 & 0,00 & 0,00 & & & & & & & & & & & \\
\hline 22 & A. teixeirana - híb - BA1 & 0,00 & 0,00 & 0,00 & 0,00 & 0,00 & 0,00 & & & & & & & & & & \\
\hline 23 & A. teixeirana - híb - BA4 & 0,01 & 0,01 & 0,01 & 0,01 & 0,01 & 0,01 & 0,01 & & & & & & & & & \\
\hline 24 & A. teixeirana - híb - CT01 & 0,00 & 0,00 & 0,00 & 0,00 & 0,00 & 0,00 & 0,00 & 0,01 & & & & & & & & \\
\hline 25 & A. teixeirana - híb - CT37 & 0,00 & 0,00 & 0,00 & 0,00 & 0,00 & 0,00 & 0,00 & 0,01 & 0,00 & & & & & & & \\
\hline 26 & A. speciosa - CT47 & 0,00 & 0,00 & 0,00 & 0,00 & 0,00 & 0,00 & 0,00 & 0,01 & 0,00 & 0,00 & & & & & & \\
\hline 27 & A. teixeirana - híb - FZ12 & 0,00 & 0,00 & 0,00 & 0,00 & 0,00 & 0,00 & 0,00 & 0,01 & 0,00 & 0,00 & 0,00 & & & & & \\
\hline 28 & A. teixeirana - híb - CT02 & 0,00 & 0,00 & 0,00 & 0,00 & 0,00 & 0,01 & 0,00 & 0,01 & 0,00 & 0,00 & 0,00 & 0,00 & & & & \\
\hline 29 & A. eichleri - СТ07 & 0,01 & 0,01 & 0,01 & 0,01 & 0,01 & 0,01 & 0,01 & 0,02 & 0,01 & 0,01 & 0,01 & 0,01 & 0,01 & & & \\
\hline 30 & A. teixeirana - híb - CT20 & 0,00 & 0,00 & 0,00 & 0,00 & 0,00 & 0,01 & 0,00 & 0,01 & 0,00 & 0,00 & 0,00 & 0,00 & 0,00 & 0,01 & & \\
\hline 31 & Cocos nucifera - GQ435464.1 & 0,00 & 0,00 & 0,00 & 0,00 & 0,00 & 0,01 & 0,00 & 0,01 & 0,01 & 0,00 & 0,00 & 0,00 & 0,01 & 0,02 & 0,01 & \\
\hline
\end{tabular}


Tabela 21. Estimativa de distâncias par a par entre as sequências de Attalea geradas para o marcador ITS (Kimura 2P)

\begin{tabular}{|c|c|c|c|c|c|c|c|c|c|c|c|c|c|c|c|c|c|c|c|c|}
\hline & & 1 & 2 & 3 & 4 & 5 & 6 & 7 & 8 & 9 & 10 & 11 & 12 & 13 & 14 & 15 & 16 & 17 & 18 & 19 \\
\hline 1 & A. speciosa - S4 & & & & & & & & & & & & & & & & & & & \\
\hline 2 & A. speciosa - S5 & 0,00 & & & & & & & & & & & & & & & & & & \\
\hline 3 & A. speciosa- $\mathrm{S} 17$ & 0,00 & 0,00 & & & & & & & & & & & & & & & & & \\
\hline 4 & A. eichleri-E19 & 0,00 & 0,00 & 0,00 & & & & & & & & & & & & & & & & \\
\hline 5 & A. eichleri-E18 & 0,00 & 0,00 & 0,00 & 0,00 & & & & & & & & & & & & & & & \\
\hline 6 & A. vitrivir $-2 \mathrm{M} 1$ & 0,00 & 0,00 & 0,00 & 0,00 & 0,01 & & & & & & & & & & & & & & \\
\hline 7 & A. vitrivir - 1BM & 0,00 & 0,00 & 0,00 & 0,00 & 0,01 & 0,00 & & & & & & & & & & & & & \\
\hline 8 & A. vitrivir - $2 \mathrm{BM}$ & 0,00 & 0,00 & 0,00 & 0,00 & 0,00 & 0,00 & 0,00 & & & & & & & & & & & & \\
\hline 9 & A. vitrivir - $1 \mathrm{M} 1$ & 0,00 & 0,00 & 0,00 & 0,00 & 0,01 & 0,00 & 0,00 & 0,00 & & & & & & & & & & & \\
\hline 10 & A. funifera -11 & 0,10 & 0,10 & 0,10 & 0,10 & 0,11 & 0,11 & 0,11 & 0,10 & 0,11 & & & & & & & & & & \\
\hline 11 & A. phalerata-P30 & 0,01 & 0,01 & 0,01 & 0,01 & 0,01 & 0,01 & 0,01 & 0,01 & 0,01 & 0,09 & & & & & & & & & \\
\hline 12 & A. barreirensis - B6 & 0,11 & 0,11 & 0,11 & 0,11 & 0,11 & 0,11 & 0,11 & 0,11 & 0,11 & 0,02 & 0,10 & & & & & & & & \\
\hline 13 & A. barreirensis - B8 & 0,10 & 0,10 & 0,10 & 0,10 & 0,11 & 0,11 & 0,11 & 0,10 & 0,11 & 0,01 & 0,09 & 0,02 & & & & & & & \\
\hline 14 & A. barreirensis - B5 & 0,11 & 0,11 & 0,11 & 0,11 & 0,12 & 0,12 & 0,12 & 0,11 & 0,12 & 0,01 & 0,10 & 0,02 & 0,02 & & & & & & \\
\hline 15 & A. barreirensis - B4 & 0,12 & 0,12 & 0,12 & 0,12 & 0,12 & 0,12 & 0,12 & 0,12 & 0,12 & 0,05 & 0,11 & 0,05 & 0,05 & 0,06 & & & & & \\
\hline 16 & A. barreirensis - B7 & 0,11 & 0,11 & 0,11 & 0,11 & 0,11 & 0,11 & 0,11 & 0,11 & 0,11 & 0,00 & 0,10 & 0,02 & 0,01 & 0,00 & 0,05 & & & & \\
\hline 17 & A. barreirensis - B1 & 0,11 & 0,11 & 0,11 & 0,11 & 0,11 & 0,11 & 0,11 & 0,11 & 0,11 & 0,01 & 0,10 & 0,02 & 0,02 & 0,01 & 0,05 & 0,00 & & & \\
\hline 18 & A. barreirensis - UB36868 & 0,11 & 0,11 & 0,11 & 0,11 & 0,11 & 0,11 & 0,11 & 0,11 & 0,11 & 0,00 & 0,10 & 0,02 & 0,01 & 0,00 & 0,05 & 0,00 & 0,00 & & \\
\hline 19 & Cocos nucifera - HQ265515.1 & 0,18 & 0,18 & 0,18 & 0,18 & 0,18 & 0,18 & 0,18 & 0,18 & 0,18 & 0,27 & 0,18 & 0,27 & 0,28 & 0,28 & 0,27 & 0,28 & 0,27 & 0,28 & \\
\hline
\end{tabular}


Tabela 22. Estimativa de distâncias par a par entre as sequências de Attalea geradas para o marcador PRK (Kimura 2P)

\begin{tabular}{|c|c|c|c|c|c|c|c|c|c|c|c|c|c|c|c|c|c|c|c|c|c|c|c|c|c|c|}
\hline & & 1 & 2 & 3 & 4 & 5 & 6 & 7 & 8 & 9 & 10 & 11 & 12 & 13 & 14 & 15 & 16 & 17 & 18 & 19 & 20 & 21 & 22 & 23 & 24 & 25 \\
\hline 1 & A. barreirensis - B1 & & & & & & & & & & & & & & & & & & & & & & & & & \\
\hline 2 & A. barrerensis - B2 & 0,01 & & & & & & & & & & & & & & & & & & & & & & & & \\
\hline 3 & A. barreirensis - B3 & 0,02 & 0,02 & & & & & & & & & & & & & & & & & & & & & & & \\
\hline 4 & A. barreirensis - B4 & 0,01 & 0,01 & 0,01 & & & & & & & & & & & & & & & & & & & & & & \\
\hline 5 & A. barreirensis - B5 & 0,02 & 0,02 & 0,00 & 0,01 & & & & & & & & & & & & & & & & & & & & & \\
\hline 6 & A. barreirensis - B6 & 0,02 & 0,02 & 0,00 & 0,01 & 0,00 & & & & & & & & & & & & & & & & & & & & \\
\hline 7 & A. barreirensis - B7 & 0,01 & 0,01 & 0,01 & 0,00 & 0,01 & 0,01 & & & & & & & & & & & & & & & & & & & \\
\hline 8 & A. barreirensis - $\mathrm{B} 8$ & 0,02 & 0,03 & 0,01 & 0,02 & 0,01 & 0,00 & 0,02 & & & & & & & & & & & & & & & & & & \\
\hline 9 & A. barreirensis - B9 & 0,02 & 0,02 & 0,00 & 0,01 & 0,00 & 0,00 & 0,01 & 0,01 & & & & & & & & & & & & & & & & & \\
\hline 10 & A. barreirensis - B10 & 0,01 & 0,01 & 0,01 & 0,00 & 0,01 & 0,02 & 0,00 & 0,02 & 0,02 & & & & & & & & & & & & & & & & \\
\hline 11 & A. barreirensis - B11 & 0,01 & 0,01 & 0,02 & 0,01 & 0,02 & 0,02 & 0,01 & 0,02 & 0,01 & 0,01 & & & & & & & & & & & & & & & \\
\hline 12 & A. barreirensis - B12 & 0,01 & 0,00 & 0,03 & 0,01 & 0,03 & 0,03 & 0,01 & 0,03 & 0,02 & 0,01 & 0,01 & & & & & & & & & & & & & & \\
\hline 13 & A. funifera -1 & 0,03 & 0,03 & 0,03 & 0,03 & 0,03 & 0,03 & 0,03 & 0,04 & 0,03 & 0,03 & 0,04 & 0,04 & & & & & & & & & & & & & \\
\hline 14 & A. funifera - 2 & 0,03 & 0,03 & 0,03 & 0,03 & 0,03 & 0,03 & 0,03 & 0,04 & 0,03 & 0,03 & 0,04 & 0,04 & 0,00 & & & & & & & & & & & & \\
\hline 15 & A. funifera - 3 & 0,03 & 0,03 & 0,03 & 0,03 & 0,03 & 0,03 & 0,03 & 0,04 & 0,03 & 0,03 & 0,04 & 0,04 & 0,00 & 0,00 & & & & & & & & & & & \\
\hline 16 & A. funifera - 4 & 0,03 & 0,03 & 0,03 & 0,03 & 0,03 & 0,03 & 0,03 & 0,03 & 0,03 & 0,03 & 0,03 & 0,04 & 0,00 & 0,00 & 0,00 & & & & & & & & & & \\
\hline 17 & A. funifera -5 & 0,03 & 0,04 & 0,03 & 0,03 & 0,03 & 0,03 & 0,03 & 0,04 & 0,04 & 0,04 & 0,04 & 0,04 & 0,00 & 0,00 & 0,00 & 0,00 & & & & & & & & & \\
\hline 18 & A. funifera -6 & 0,03 & 0,03 & 0,03 & 0,03 & 0,03 & 0,03 & 0,03 & 0,04 & 0,03 & 0,03 & 0,04 & 0,04 & 0,01 & 0,01 & 0,01 & 0,00 & 0,01 & & & & & & & & \\
\hline 19 & A. funifera -8 & 0,03 & 0,03 & 0,03 & 0,03 & 0,03 & 0,03 & 0,03 & 0,04 & 0,03 & 0,03 & 0,04 & 0,04 & 0,00 & 0,00 & 0,00 & 0,00 & 0,00 & 0,01 & & & & & & & \\
\hline 20 & A. funifera -9 & 0,03 & 0,03 & 0,03 & 0,03 & 0,03 & 0,03 & 0,03 & 0,03 & 0,03 & 0,03 & 0,03 & 0,04 & 0,00 & 0,00 & 0,00 & 0,00 & 0,00 & 0,01 & 0,00 & & & & & & \\
\hline 21 & A. funifera - 10 & 0,03 & 0,03 & 0,03 & 0,03 & 0,03 & 0,03 & 0,03 & 0,03 & 0,03 & 0,03 & 0,03 & 0,04 & 0,00 & 0,00 & 0,00 & 0,00 & 0,00 & 0,00 & 0,00 & 0,00 & & & & & \\
\hline 22 & A. funifera - 12 & 0,03 & 0,04 & 0,03 & 0,03 & 0,03 & 0,03 & 0,03 & 0,04 & 0,04 & 0,04 & 0,03 & 0,04 & 0,00 & 0,00 & 0,00 & 0,00 & 0,00 & 0,01 & 0,00 & 0,00 & 0,00 & & & & \\
\hline 23 & A. maripa - 1 & 0,01 & 0,02 & 0,01 & 0,02 & 0,01 & 0,02 & 0,02 & 0,02 & 0,02 & 0,02 & 0,02 & 0,02 & 0,03 & 0,03 & 0,03 & 0,03 & 0,03 & 0,03 & 0,03 & 0,02 & 0,03 & 0,03 & & & \\
\hline 24 & A. maripa - 4 & 0,01 & 0,02 & 0,01 & 0,02 & 0,01 & 0,02 & 0,02 & 0,02 & 0,02 & 0,02 & 0,02 & 0,02 & 0,03 & 0,03 & 0,03 & 0,03 & 0,03 & 0,03 & 0,03 & 0,03 & 0,03 & 0,03 & 0,00 & & \\
\hline 25 & A. maripa -5 & 0,02 & 0,02 & 0,02 & 0,02 & 0,02 & 0,02 & 0,02 & 0,02 & 0,02 & 0,02 & 0,02 & 0,03 & 0,03 & 0,03 & 0,03 & 0,03 & 0,03 & 0,03 & 0,03 & 0,03 & 0,03 & 0,03 & 0,00 & 0,01 & \\
\hline 26 & A. maripa -6 & 0,02 & 0,02 & 0,02 & 0,02 & 0,02 & 0,01 & 0,02 & 0,02 & 0,02 & 0,02 & 0,02 & 0,03 & 0,03 & 0,03 & 0,03 & 0,03 & 0,03 & 0,03 & 0,03 & 0,02 & 0,03 & 0,03 & 0,00 & 0,01 & 0,00 \\
\hline 27 & A. maripa - 7 & 0,01 & 0,02 & 0,01 & 0,02 & 0,01 & 0,02 & 0,02 & 0,02 & 0,02 & 0,02 & 0,02 & 0,02 & 0,03 & 0,03 & 0,03 & 0,03 & 0,03 & 0,03 & 0,03 & 0,02 & 0,03 & 0,03 & 0,00 & 0,00 & 0,00 \\
\hline 28 & A. cohune - AY601239. 1 & 0,01 & 0,02 & 0,01 & 0,01 & 0,01 & 0,02 & 0,01 & 0,02 & 0,02 & 0,02 & 0,02 & 0,02 & 0,03 & 0,03 & 0,03 & 0,02 & 0,03 & 0,03 & 0,03 & 0,02 & 0,02 & 0,03 & 0,01 & 0,01 & 0,01 \\
\hline 29 & A. cuatrecasana - AY601241.1 & 0,01 & 0,02 & 0,01 & 0,02 & 0,01 & 0,01 & 0,02 & 0,02 & 0,01 & 0,02 & 0,02 & 0,02 & 0,03 & 0,03 & 0,03 & 0,03 & 0,03 & 0,03 & 0,03 & 0,03 & 0,03 & 0,03 & 0,01 & 0,01 & 0,02 \\
\hline 30 & A. oleifera - AY601238.1 & 0,02 & 0,03 & 0,02 & 0,02 & 0,02 & 0,02 & 0,02 & 0,03 & 0,03 & 0,03 & 0,03 & 0,03 & 0,02 & 0,02 & 0,02 & 0,02 & 0,02 & 0,02 & 0,02 & 0,02 & 0,02 & 0,02 & 0,02 & 0,02 & 0,02 \\
\hline
\end{tabular}


Continuação da Tabela 22. Estimativa de distâncias par a par entre as sequências de Attalea geradas para o marcador PRK (Kimura 2P)

\begin{tabular}{|c|c|c|c|c|c|c|c|c|c|c|c|c|c|c|c|c|c|c|c|c|c|c|c|c|c|c|}
\hline & & 26 & 27 & 28 & 29 & 30 & 31 & 32 & 33 & 34 & 35 & 36 & 37 & 38 & 39 & 40 & 41 & 42 & 43 & 44 & 45 & 46 & 47 & 48 & 49 & 50 \\
\hline 1 & A. barreirensis - B1 & & & & & & & & & & & & & & & & & & & & & & & & & \\
\hline 2 & A. barreirensis - B2 & & & & & & & & & & & & & & & & & & & & & & & & & \\
\hline 3 & A. barreirensis - B3 & & & & & & & & & & & & & & & & & & & & & & & & & \\
\hline 4 & A. barreirensis - B4 & & & & & & & & & & & & & & & & & & & & & & & & & \\
\hline 5 & A. barreirensis - B5 & & & & & & & & & & & & & & & & & & & & & & & & & \\
\hline 6 & A. barreirensis - B6 & & & & & & & & & & & & & & & & & & & & & & & & & \\
\hline 7 & A. barreirensis - B7 & & & & & & & & & & & & & & & & & & & & & & & & & \\
\hline 8 & A. barreirensis - B8 & & & & & & & & & & & & & & & & & & & & & & & & & \\
\hline 9 & A. barreirensis - B9 & & & & & & & & & & & & & & & & & & & & & & & & & \\
\hline 10 & A. barreirensis - B10 & & & & & & & & & & & & & & & & & & & & & & & & & \\
\hline 11 & A. barreirensis - B11 & & & & & & & & & & & & & & & & & & & & & & & & & \\
\hline 12 & A. barreirensis - B12 & & & & & & & & & & & & & & & & & & & & & & & & & \\
\hline 13 & A. funifera - 1 & & & & & & & & & & & & & & & & & & & & & & & & & \\
\hline 14 & A. funifera -2 & & & & & & & & & & & & & & & & & & & & & & & & & \\
\hline 15 & A. funifera -3 & & & & & & & & & & & & & & & & & & & & & & & & & \\
\hline 16 & A. funifera -4 & & & & & & & & & & & & & & & & & & & & & & & & & \\
\hline 17 & A. funifera -5 & & & & & & & & & & & & & & & & & & & & & & & & & \\
\hline 18 & A. funifera -6 & & & & & & & & & & & & & & & & & & & & & & & & & \\
\hline 19 & A. funifera -8 & & & & & & & & & & & & & & & & & & & & & & & & & \\
\hline 20 & A. funifera -9 & & & & & & & & & & & & & & & & & & & & & & & & & \\
\hline 21 & A. funifera -10 & & & & & & & & & & & & & & & & & & & & & & & & & \\
\hline 22 & A. funifera -12 & & & & & & & & & & & & & & & & & & & & & & & & & \\
\hline 23 & A. maripa - 1 & & & & & & & & & & & & & & & & & & & & & & & & & \\
\hline 24 & A. maripa - 4 & & & & & & & & & & & & & & & & & & & & & & & & & \\
\hline 25 & A. maripa - 5 & & & & & & & & & & & & & & & & & & & & & & & & & \\
\hline 26 & A. maripa -6 & & & & & & & & & & & & & & & & & & & & & & & & & \\
\hline 27 & A. maripa -7 & 0,00 & & & & & & & & & & & & & & & & & & & & & & & & \\
\hline 28 & A. cohune - AY601239. 1 & 0,01 & 0,01 & & & & & & & & & & & & & & & & & & & & & & & \\
\hline 29 & A. cuatrecasana - AY601241.1 & 0,02 & 0,01 & 0,01 & & & & & & & & & & & & & & & & & & & & & & \\
\hline 30 & A. oleifera - AY601238.1 & 0,02 & 0,02 & 0,02 & 0,02 & & & & & & & & & & & & & & & & & & & & & \\
\hline
\end{tabular}


Continuação da Tabela 22. Estimativa de distâncias par a par entre as sequências de Attalea geradas para o marcador PRK (Kimura 2P)

\begin{tabular}{|c|c|c|c|c|c|c|c|c|c|c|c|c|c|c|c|c|c|c|c|c|c|c|c|c|c|c|}
\hline & & 1 & 2 & 3 & 4 & 5 & 6 & 7 & 8 & 9 & 10 & 11 & 12 & 13 & 14 & 15 & 16 & 17 & 18 & 19 & 20 & 21 & 22 & 23 & 24 & 25 \\
\hline 31 & A. allenii - AJ831346.1 & 0,01 & 0,02 & 0,01 & 0,01 & 0,01 & 0,02 & 0,01 & 0,02 & 0,02 & 0,02 & 0,02 & 0,02 & 0,03 & 0,03 & 0,03 & 0,02 & 0,03 & 0,03 & 0,03 & 0,02 & 0,02 & 0,03 & 0,01 & 0,01 & 0,01 \\
\hline 32 & eichleri- СТ07 & 0,01 & 0,01 & 0,01 & 0,01 & 0,01 & 0,01 & 0,01 & 0,02 & 0,01 & 0,01 & 0,02 & 0,02 & 0,02 & 0,02 & 0,02 & 0,02 & 0,03 & 0,02 & 0,02 & 0,02 & 0,02 & 0,03 & 0,01 & 0,01 & 0,01 \\
\hline 33 & A. teixeirana - híb-CT16 & 0,01 & 0,01 & 0,01 & 0,01 & 0,01 & 0,01 & 0,01 & 0,02 & 0,01 & 0,01 & 0,02 & 0,02 & 0,02 & 0,02 & 0,02 & 0,02 & 0,03 & 0,02 & 0,02 & 0,02 & 0,02 & 0,03 & 0,01 & 0,01 & 0,01 \\
\hline 34 & A. teixeirana - híb - CT22 & 0,01 & 0,01 & 0,01 & 0,01 & 0,01 & 0,01 & 0,01 & 0,02 & 0,01 & 0,01 & 0,02 & 0,02 & 0,02 & 0,02 & 0,02 & 0,02 & 0,03 & 0,02 & 0,02 & 0,02 & 0,02 & 0,03 & 0,01 & 0,01 & 0,01 \\
\hline 35 & A. speciosa - СТ46 & 0,01 & 0,01 & 0,01 & 0,01 & 0,01 & 0,01 & 0,01 & 0,02 & 0,01 & 0,01 & 0,02 & 0,02 & 0,02 & 0,02 & 0,02 & 0,02 & 0,03 & 0,02 & 0,02 & 0,02 & 0,02 & 0,03 & 0,01 & 0,01 & 0,01 \\
\hline 36 & A. teixeirana - híb - СТ02 & 0,01 & 0,02 & 0,01 & 0,01 & 0,01 & 0,02 & 0,01 & 0,02 & 0,02 & 0,02 & 0,02 & 0,02 & 0,03 & 0,03 & 0,03 & 0,02 & 0,03 & 0,03 & 0,03 & 0,02 & 0,02 & 0,03 & 0,01 & 0,01 & 0,01 \\
\hline 37 & A. vitrivir-8BM & 0,01 & 0,01 & 0,01 & 0,01 & 0,01 & 0,01 & 0,01 & 0,02 & 0,01 & 0,01 & 0,02 & 0,02 & 0,02 & 0,02 & 0,02 & 0,02 & 0,03 & 0,02 & 0,02 & 0,02 & 0,02 & 0,03 & 0,01 & 0,01 & 0,01 \\
\hline 38 & A. speciosa - AY601245.1 & 0,01 & 0,01 & 0,01 & 0,01 & 0,01 & 0,01 & 0,01 & 0,02 & 0,01 & 0,01 & 0,02 & 0,02 & 0,02 & 0,02 & 0,02 & 0,02 & 0,03 & 0,02 & 0,02 & 0,02 & 0,02 & 0,03 & 0,01 & 0,01 & 0,01 \\
\hline 39 & A. speciosa - UB10110 & 0,02 & 0,02 & 0,02 & 0,02 & 0,02 & 0,02 & 0,02 & 0,03 & 0,02 & 0,02 & 0,02 & 0,02 & 0,03 & 0,03 & 0,03 & 0,03 & 0,03 & 0,03 & 0,03 & 0,03 & 0,03 & 0,04 & 0,02 & 02 & 0,02 \\
\hline 40 & A. speciosa- $\mathbf{S} 6$ & 0,01 & 0,02 & 0,02 & 0,02 & 0,02 & 0,02 & 0,02 & 0,02 & 0,02 & 0,02 & 0,02 & 0,02 & 0,03 & 0,03 & ,03 & 0,03 & 0,03 & 0,03 & 0,03 & 0,03 & 0,03 & 0,03 & 0,01 & 0,01 & 0,02 \\
\hline 41 & A. specios & 0,01 & 0,01 & 0,01 & 0,01 & 0,01 & 0,01 & 0,01 & 0,02 & 0,01 & 0,01 & 0,01 & 0,02 & 0,02 & 0,02 & 0,02 & 0,02 & 0,02 & 0,02 & 0,02 & 0,02 & 0,02 & 0,02 & 0,01 & 0,01 & 0,01 \\
\hline 42 & A. speciosa - S9 & 0,01 & 0,01 & 0,01 & 0,01 & 0,01 & 0,01 & 0,01 & 0,02 & 0,01 & 0,01 & 0,01 & 0,02 & 0,02 & 0,02 & 0,02 & 0,02 & 0,02 & 0,02 & 0,02 & 0,02 & 0,02 & 0,02 & 0,01 & 01 & 0,01 \\
\hline 43 & A. speciosa-S3 & 0,01 & 0,02 & 0,01 & 0,01 & 0,01 & 0,02 & 0,01 & 0,02 & 0,02 & 0,02 & 0,02 & 0,02 & 0,03 & 0,03 & 0,03 & 0,02 & 0,03 & 0,03 & 0,03 & 0,02 & 0,02 & 0,03 & 0,01 & 0,01 & 0,01 \\
\hline 44 & A. speciosa - $\mathbf{S 4}$ & 0,03 & 0,04 & 0,03 & 0,03 & 0,03 & 0,04 & 0,03 & 0,04 & 0,04 & 0,04 & 0,04 & 0,04 & 0,05 & 0,05 & 0,05 & 0,05 & 0,05 & 0,05 & 0,05 & 0,05 & 0,05 & 0,05 & 0,03 & 03 & 0,04 \\
\hline 45 & A. speciosa-S5 & 0,01 & 0,02 & 0,01 & 0,01 & 0,01 & 0,02 & 0,01 & 0,02 & 0,02 & 0,02 & 0,02 & 0,02 & 0,03 & 0,03 &, 03 & 0,02 & 0,03 & 0,03 & 0,03 & 0,02 & 0,02 & 0,03 & 0,01 & 01 & 0,01 \\
\hline 46 & A. spe & 0,01 & 0,02 & 0,01 & 0,01 & 0,01 & 0,02 & 0,01 & 0,02 & 0,02 & 0,02 & 0,02 & 0,02 & 0,03 & 0,03 & ,03 & 02 & 0,03 & 0,03 & 03 & ,02 & 0,02 & 0,03 & 0,01 & 01 & 0,01 \\
\hline 47 & A. eic & 0,01 & 0,02 & 0,01 & 0,01 & 0,01 & 0,02 & 0,01 & 0,02 & 0,02 & 0,02 & 0,02 & 0,02 & 0,03 & 0,03 & 0,03 & 0,02 & 0,03 & 0,03 & 0,03 & 0,02 & 0,02 & 0,03 & 0,01 & 01 & 0,01 \\
\hline 48 & A. eichleri-E11 & 0,01 & 0,01 & 0,01 & 0,01 & 0,01 & 0,01 & 0,01 & 0,02 & 0,01 & 0,01 & 0,01 & 0,02 & 0,02 & 0,02 & 02 & 0,02 & 0,02 & 0,02 & 0,02 & 0,02 & 0,02 & 0,02 & 0,01 & 01 & 0,01 \\
\hline 49 & A. phalerata - AY601240.2 & 0,01 & 0,02 & 0,02 & 0,02 & 0,02 & 0,02 & 0,02 & 0,02 & 0,02 & 0,02 & 0,02 & 0,02 & 0,03 & 0,03 & 0,03 & 0,03 & 0,03 & 0,03 & 0,03 & 0,03 & 0,03 & 0,03 & 0,01 & 0,01 & 0,02 \\
\hline 50 & Cocos nucifera - AY601235.1 & 0,06 & 0,07 & 0,07 & 0,06 & 0,07 & 0,07 & 0,06 & 0,08 & 0,07 & 0,07 & 0,07 & 0,07 & 0,07 & 0,07 & 0,07 & 0,07 & 0,07 & 0,07 & 0,07 & 0,07 & 0,07 & 0,08 & 0,07 & 0,07 & 0,07 \\
\hline
\end{tabular}


Continuação da Tabela 22. Estimativa de distâncias par a par entre as sequências de Attalea geradas para o marcador PRK (Kimura 2P)

\begin{tabular}{|c|c|c|c|c|c|c|c|c|c|c|c|c|c|c|c|c|c|c|c|c|c|c|c|c|c|c|}
\hline & & 26 & 27 & 28 & 29 & 30 & 31 & 32 & 33 & 34 & 35 & 36 & 37 & 38 & 39 & 40 & 41 & 42 & 43 & 44 & 45 & 46 & 47 & 48 & 49 & 50 \\
\hline 31 & A. allenii - AJ831346.1 & 0,01 & 0,01 & 0,00 & 0,01 & 0,02 & & & & & & & & & & & & & & & & & & & & \\
\hline 32 & A. eichleri- Ст07 & 0,01 & 0,01 & 0,01 & 0,01 & 0,02 & 0,01 & & & & & & & & & & & & & & & & & & & \\
\hline 33 & A. teixeirana - híb - CT16 & 0,01 & 0,01 & 0,01 & 0,01 & 0,02 & 0,01 & 0,00 & & & & & & & & & & & & & & & & & & \\
\hline 34 & A. teixeirana - híb - CT22 & 0,01 & 0,01 & 0,01 & 0,01 & 0,02 & 0,01 & 0,00 & 0,00 & & & & & & & & & & & & & & & & & \\
\hline 35 & A. speciosa - СТ46 & 0,01 & 0,01 & 0,01 & 0,01 & 0,02 & 0,01 & 0,00 & 0,00 & 0,00 & & & & & & & & & & & & & & & & \\
\hline 36 & A. teixeirana - híb - CT02 & 0,01 & 0,01 & 0,01 & 0,01 & 0,02 & 0,01 & 0,00 & 0,01 & 0,00 & 0,00 & & & & & & & & & & & & & & & \\
\hline 37 & A. vitrivir-8BM & 0,01 & 0,01 & 0,01 & 0,01 & 0,02 & 0,01 & 0,00 & 0,00 & 0,00 & 0,00 & 0,00 & & & & & & & & & & & & & & \\
\hline 38 & A. speciosa - AY601245.1 & 0,01 & 0,01 & 0,01 & 0,01 & 0,02 & 0,01 & 0,00 & 0,00 & 0,00 & 0,00 & 0,00 & 0,00 & & & & & & & & & & & & & \\
\hline 39 & A. speciosa - UB10110 & 0,02 & 0,02 & 0,02 & 0,02 & 0,03 & 0,02 & 0,01 & 0,01 & 0,01 & 0,01 & 0,02 & 0,01 & 0,01 & & & & & & & & & & & & \\
\hline 40 & A. speciosa - S6 & 0,02 & 0,01 & 0,01 & 0,01 & 0,02 & 0,01 & 0,01 & 0,01 & 0,01 & 0,01 & 0,01 & 0,01 & 0,01 & 0,02 & & & & & & & & & & & \\
\hline 41 & A. speciosa - $\mathbf{s 7}$ & 0,01 & 0,01 & 0,00 & 0,01 & 0,01 & 0,00 & 0,00 & 0,00 & 0,00 & 0,00 & 0,00 & 0,00 & 0,00 & 0,01 & 0,01 & & & & & & & & & & \\
\hline 42 & A. speciosa-S9 & 0,01 & 0,01 & 0,00 & 0,01 & 0,01 & 0,00 & 0,00 & 0,00 & 0,00 & 0,00 & 0,00 & 0,00 & 0,00 & 0,01 & 0,01 & 0,00 & & & & & & & & & \\
\hline 43 & A. speciosa - $\mathbf{s 3}$ & 0,01 & 0,01 & 0,01 & 0,01 & 0,02 & 0,01 & 0,01 & 0,01 & 0,01 & 0,01 & 0,01 & 0,01 & 0,01 & 0,02 & 0,01 & 0,00 & 0,00 & & & & & & & & \\
\hline 44 & A. speciosa-S4 & 0,04 & 0,03 & 0,03 & 0,03 & 0,04 & 0,03 & 0,03 & 0,03 & 0,03 & 0,03 & 0,03 & 0,03 & 0,03 & 0,04 & 0,03 & 0,03 & 0,03 & 0,03 & & & & & & & \\
\hline 45 & A. speciosa- S5 & 0,01 & 0,01 & 0,01 & 0,01 & 0,02 & 0,01 & 0,01 & 0,01 & 0,01 & 0,01 & 0,01 & 0,01 & 0,01 & 0,02 & 0,01 & 0,00 & 0,00 & 0,01 & 0,03 & & & & & & \\
\hline 46 & A. speciosa - S8 & 0,01 & 0,01 & 0,01 & 0,01 & 0,02 & 0,01 & 0,01 & 0,01 & 0,01 & 0,01 & 0,01 & 0,01 & 0,01 & 0,02 & 0,01 & 0,00 & 0,00 & 0,01 & 0,03 & 0,00 & & & & & \\
\hline 47 & A. eichleri - E4 & 0,01 & 0,01 & 0,01 & 0,01 & 0,02 & 0,01 & 0,00 & 0,01 & 0,00 & 0,00 & 0,00 & 0,00 & 0,00 & 0,02 & 0,01 & 0,00 & 0,00 & 0,01 & 0,03 & 0,01 & 0,01 & & & & \\
\hline 48 & A. eichleri - E11 & 0,01 & 0,01 & 0,00 & 0,01 & 0,01 & 0,00 & 0,00 & 0,00 & 0,00 & 0,00 & 0,00 & 0,00 & 0,00 & 0,01 & 0,01 & 0,00 & 0,00 & 0,00 & 0,03 & 0,00 & 0,00 & 0,00 & & & \\
\hline 49 & A. phalerata - AY601240.2 & 0,02 & 0,01 & 0,01 & 0,01 & 0,02 & 0,01 & 0,01 & 0,01 & 0,01 & 0,01 & 0,01 & 0,01 & 0,01 & 0,02 & 0,01 & 0,01 & 0,01 & 0,01 & 0,03 & 0,01 & 0,01 & 0,01 & 0,01 & & \\
\hline 50 & Cocos nucifera - AY601235.1 & 0,07 & 0,07 & 0,06 & 0,06 & 0,07 & 0,06 & 0,06 & 0,06 & 0,06 & 0,06 & 0,06 & 0,06 & 0,06 & 0,07 & 0,06 & 0,06 & 0,06 & 0,06 & 0,09 & 0,06 & 0,06 & 0,06 & 0,06 & 0,06 & \\
\hline
\end{tabular}


Anexo IV. Árvores de MP e MV

matK - MP

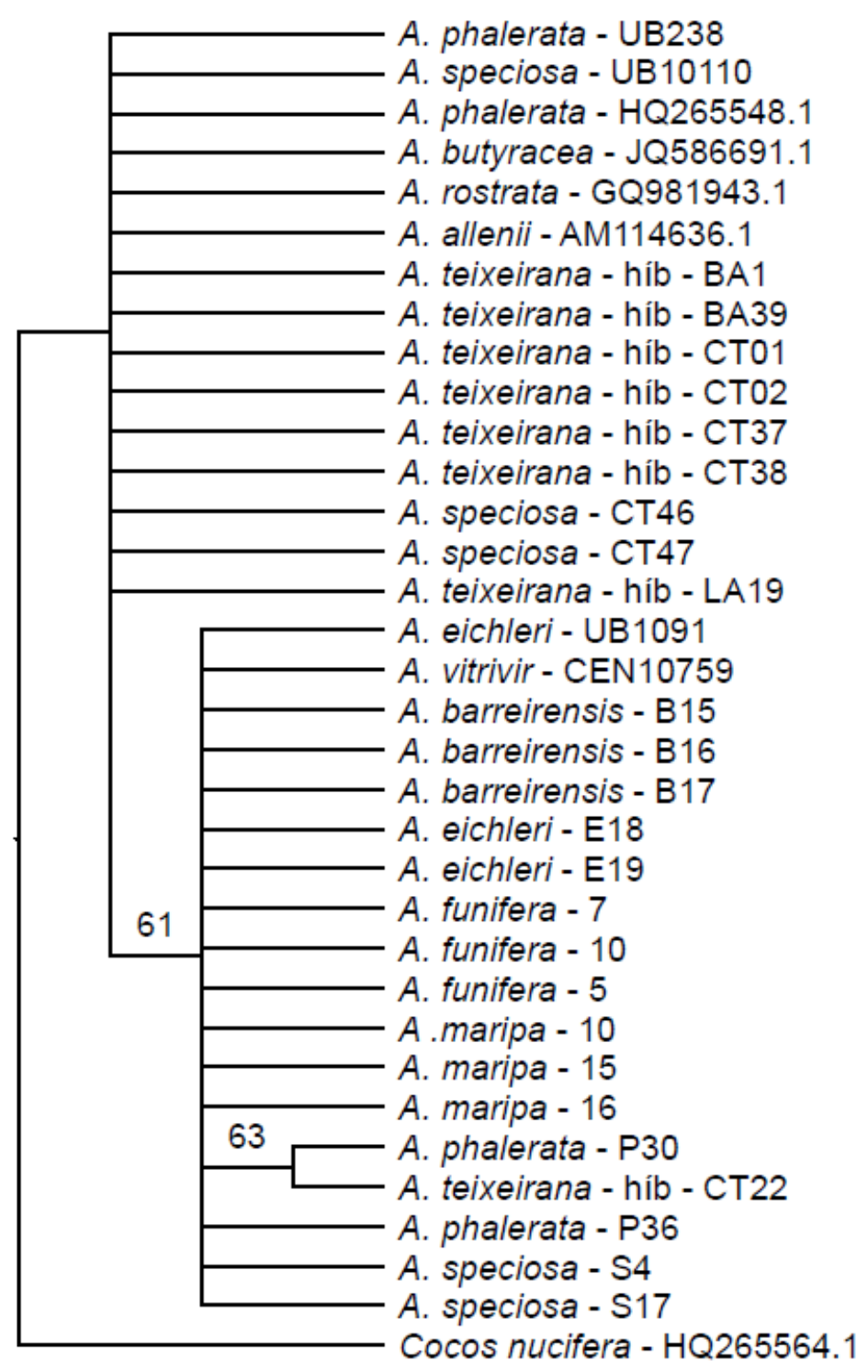

$\overline{0.3}$

Figura 32. Árvore filogenética de Máxima Parcimônia gerada a partir de sequências do gene matK, mostrando relações entre espécies do gênero Attalea. $\mathrm{O}$ valores de bootstrap significativos (maior que 50\%) estão representados nos nós. Cocos nucifera (HQ265564.1) foi utilizado como outgroup. As árvores de consenso de bootstrap foram inferidas a partir de 1.000 repetições. 


\section{$\operatorname{rbcL}-\mathrm{MP}$}

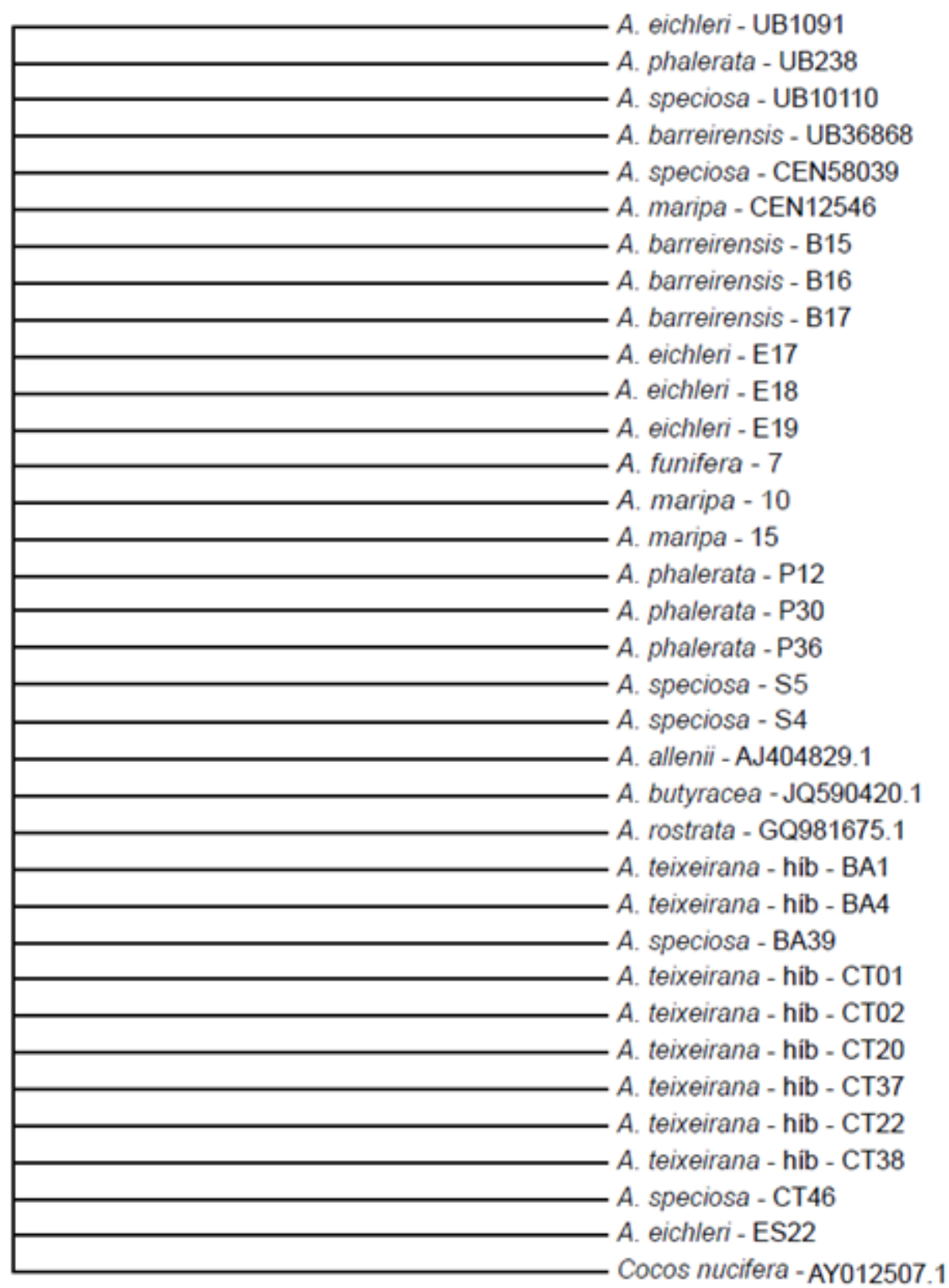

Figura 33. Árvore filogenética de Máxima Parcimônia gerada a partir de sequências do gene $r b c L$, mostrando relações entre espécies do gênero Attalea. O valores de bootstrap significativos (maior que 50\%) estão representados nos nós. Cocos nucifera (AY012507.1) foi utilizado como outgroup. As árvores de consenso de bootstrap foram inferidas a partir de 1.000 repetições. 


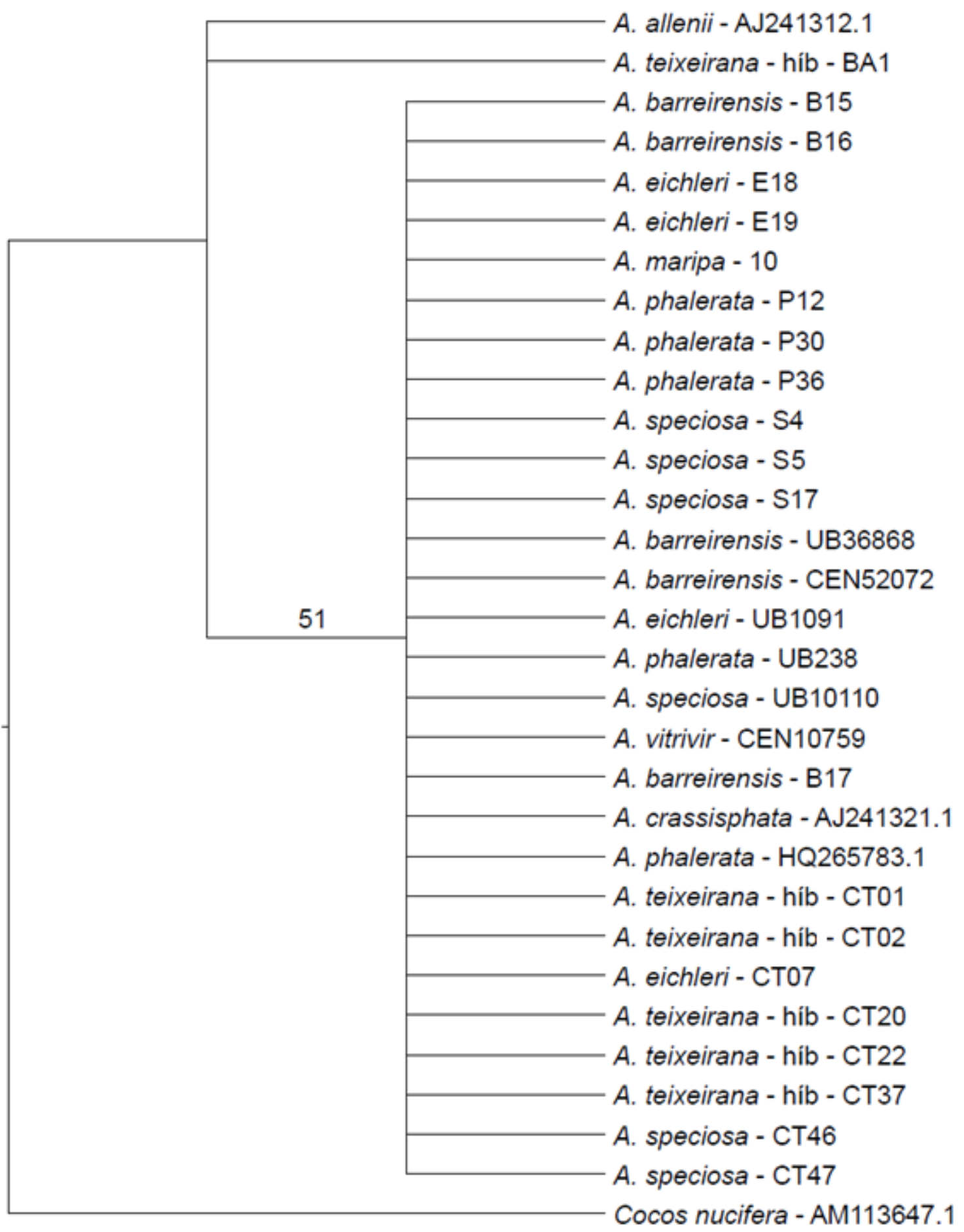

Figura 34. Árvore filogenética de Máxima Parcimônia gerada a partir de sequências do gene $\operatorname{trnL}$, mostrando relações entre espécies do gênero Attalea. O valores de bootstrap significativos (maior que 50\%) estão representados nos nós. Cocos nucifera (AM113647.1) foi utilizado como outgroup. As árvores de consenso de bootstrap foram inferidas a partir de 1.000 repetições. 


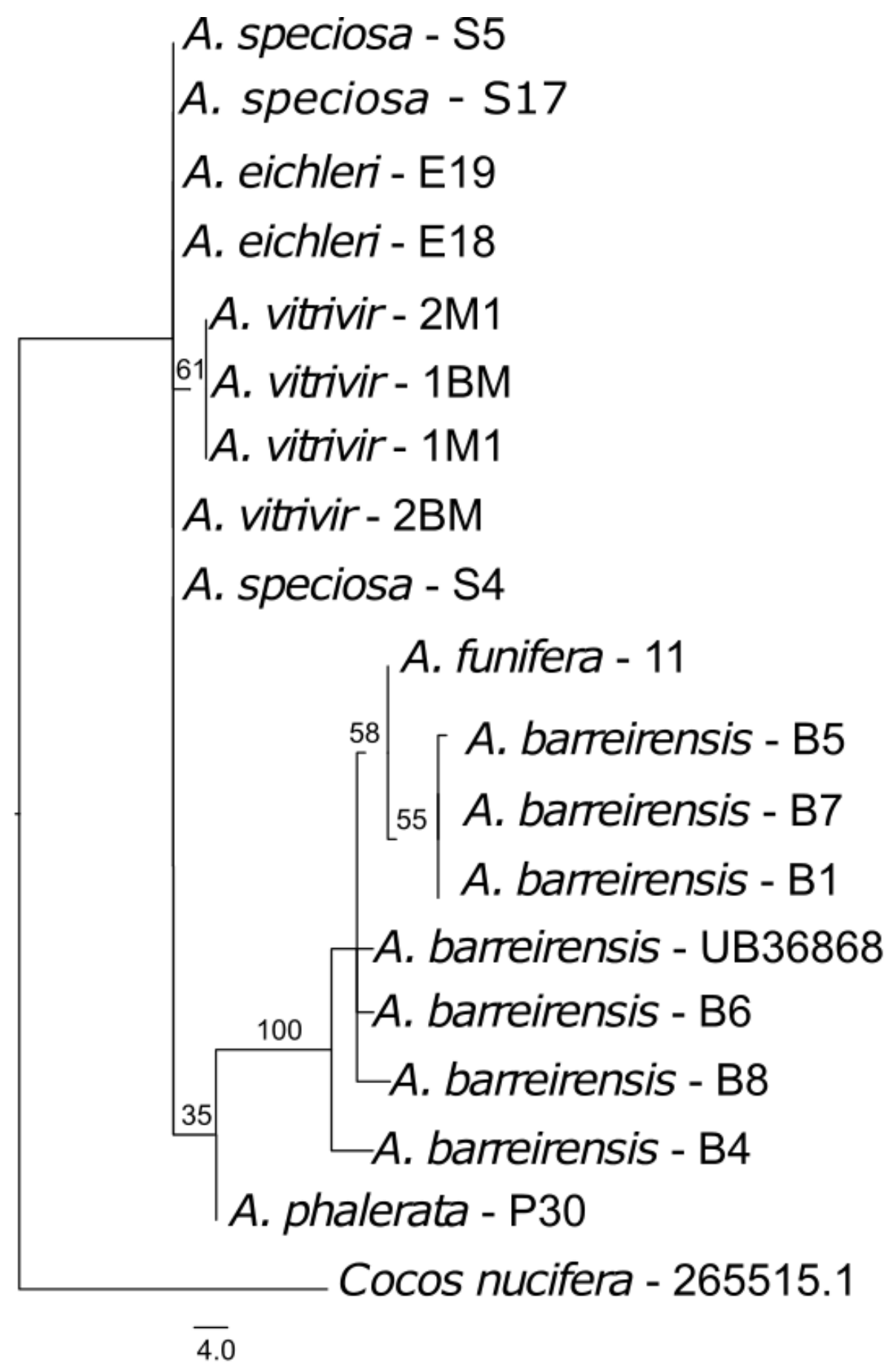

Figura 35. Árvore filogenética de Máxima Parcimônia gerada a partir de sequências do gene ITS, mostrando relações entre espécies do gênero Attalea. $\mathrm{O}$ valores de bootstrap significativos (maior que 50\%) estão representados nos nós. Cocos nucifera (HQ265515.1) foi utilizado como outgroup. As árvores de consenso de bootstrap foram inferidas a partir de 1.000 repetições. 


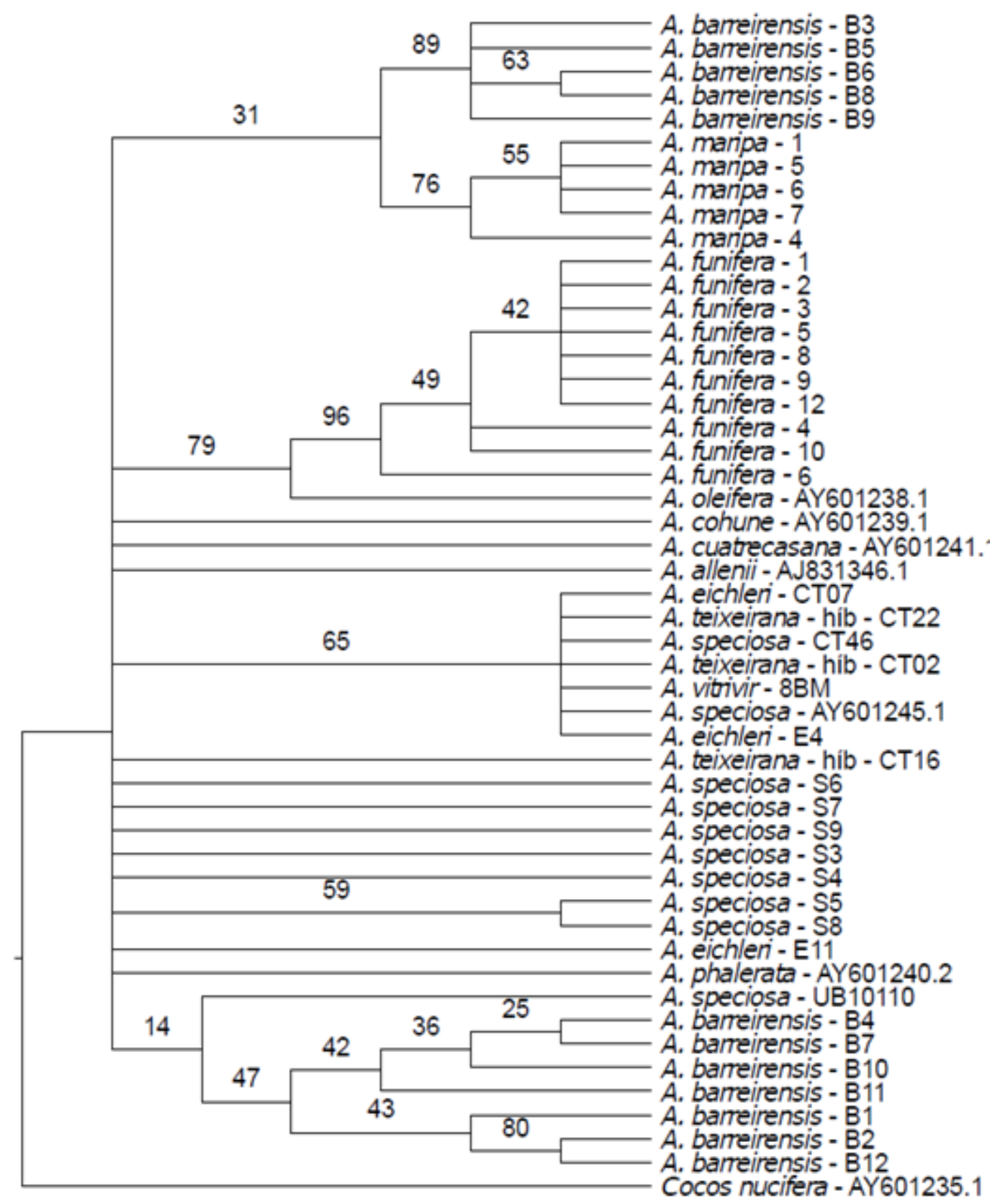

\section{9}

Figura 36. Árvore filogenética de Máxima Parcimônia gerada a partir de sequências do gene PRK, mostrando relações entre espécies do gênero Attalea. O valores de bootstrap significativos (maior que 50\%) estão representados nos nós. Cocos nucifera (AY601235.1) foi utilizado como outgroup. As árvores de consenso de bootstrap foram inferidas a partir de 1.000 repetições. 
Anexo IV - Árvores de MV

matK - MV

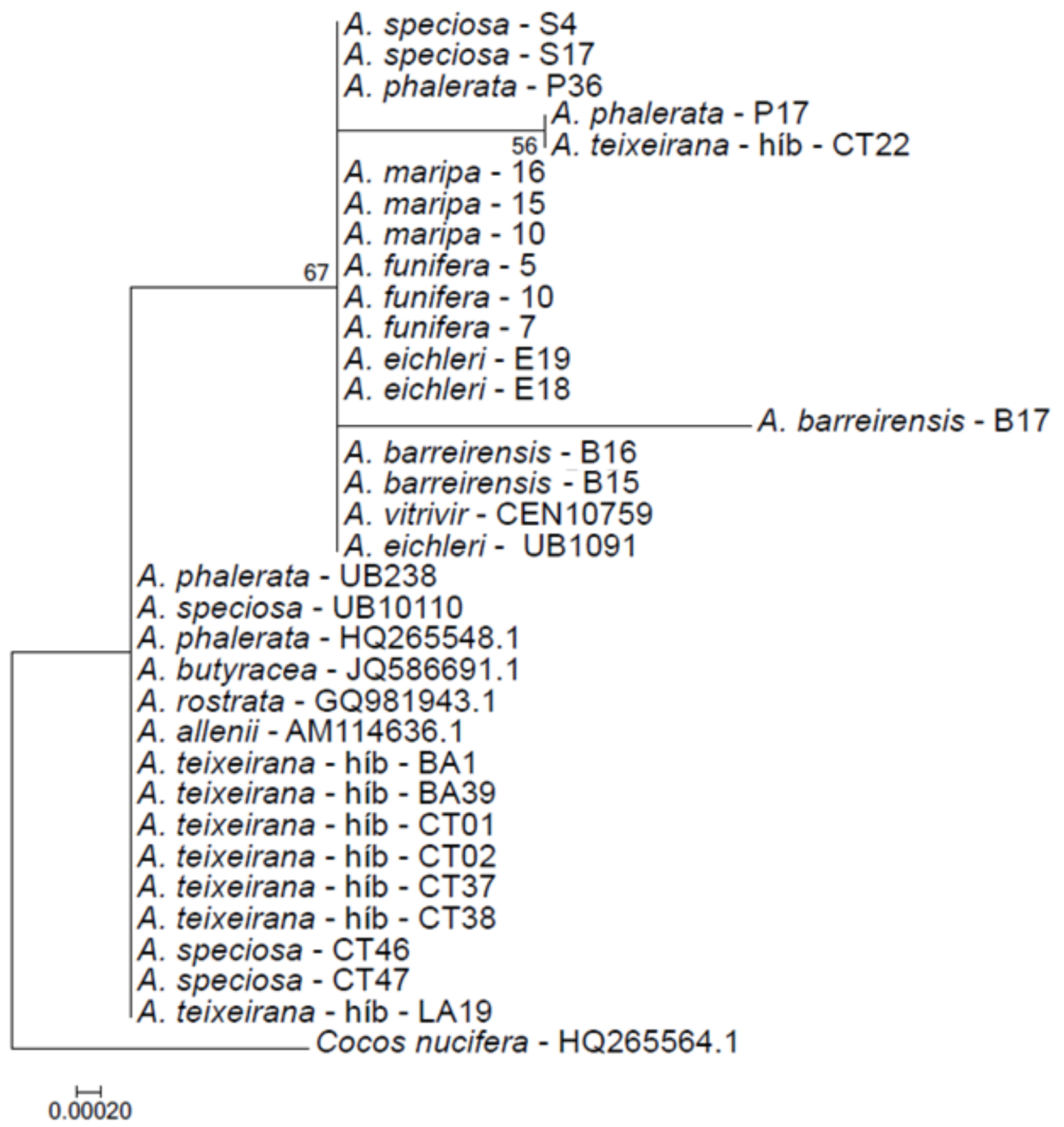

Figura 37. Árvore filogenética de Máxima Verossimilhança inferida a partir de sequências do gene matK, mostrando relações entre algumas espécies do gênero Attalea. Os valores significativos (maior que 50\%) de bootstrap (1.000 repetições) estão representados na na árvore. Cocos nucifera (HQ265564.1) foi utilizado como outgroup. 
rbcL - MV

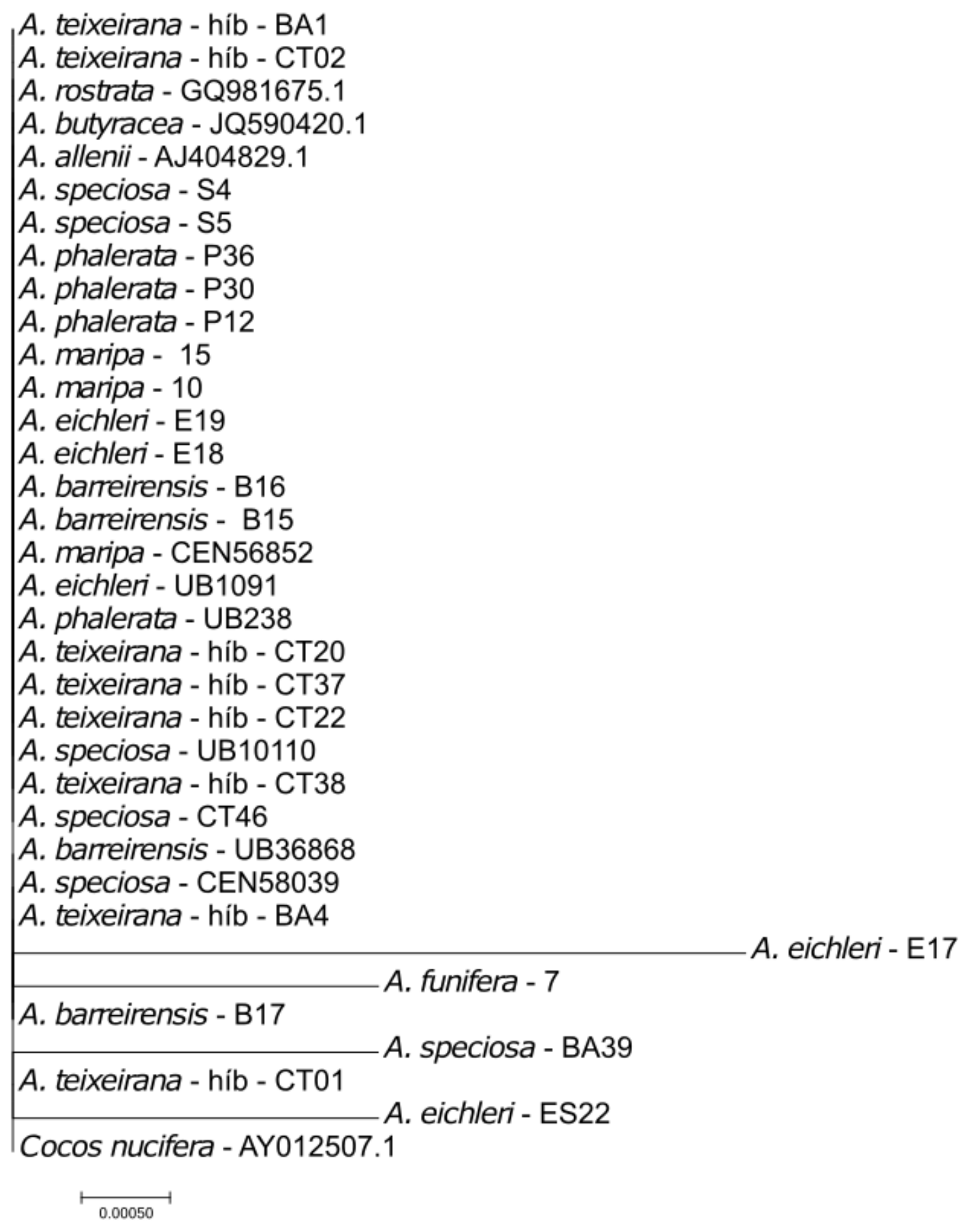

Figura 38. Árvore filogenética de Máxima Verossimilhança inferida a partir de sequências do gene $r b c L$, mostrando relações entre algumas espécies do gênero Attalea. Os valores significativos (maior que 50\%) de bootstrap (1.000 repetições) estão representados na árvore. Cocos nucifera (AY012507.1) foi utilizado como outgroup. 


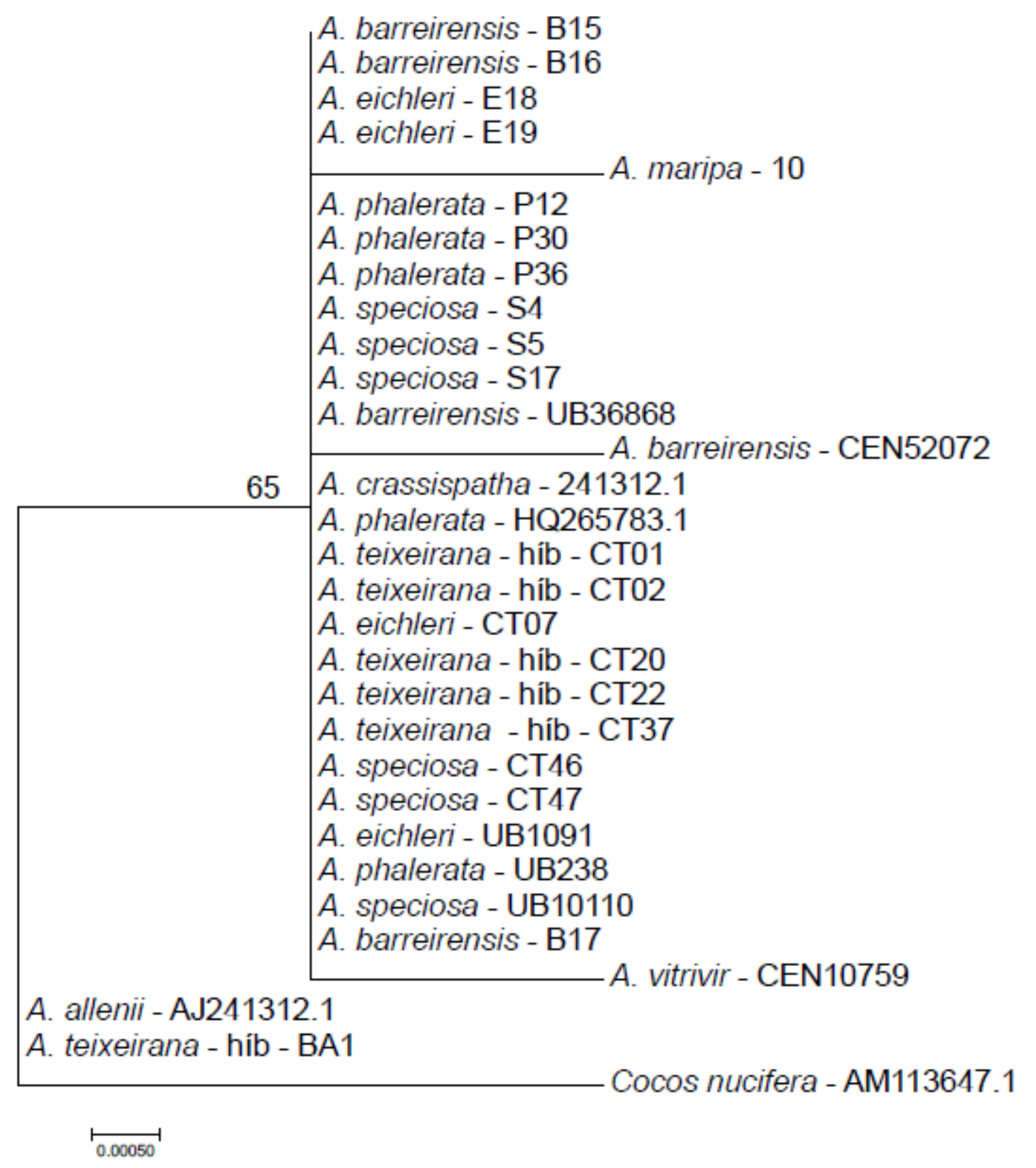

Figura 39. Árvore filogenética de Máxima Verossimilhança inferida a partir de sequências do gene trnL, mostrando relações entre algumas espécies do gênero Attalea. Os valores significativos (maior que 50\%) de bootstrap (1.000 repetições) estão representados na na árvore. Cocos nucifera (AM.113647.1) foi utilizado como outgroup. 


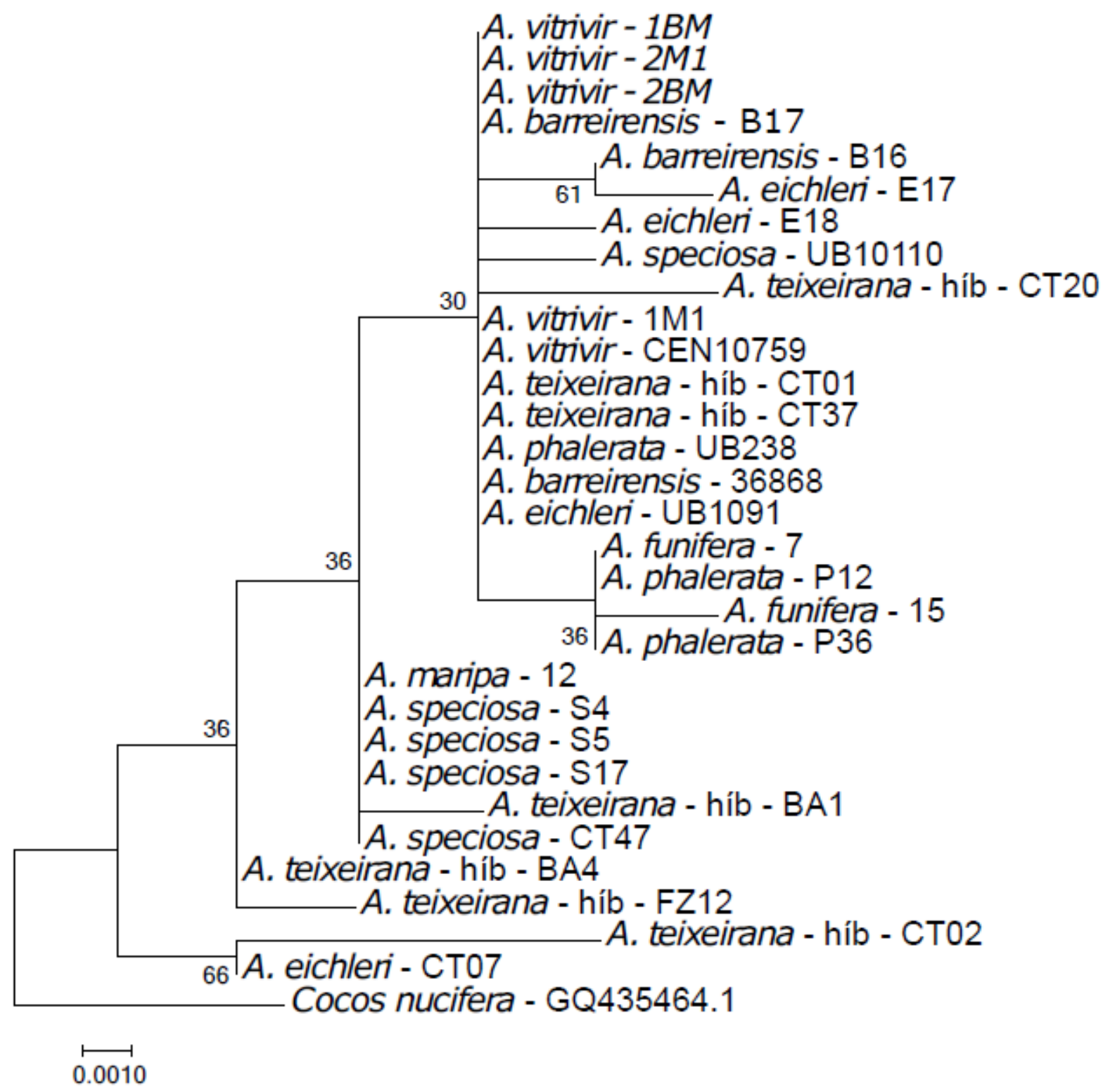

Figura 40. Árvore filogenética de Máxima Verossimilhança inferida a partir de sequências do gene psbA-trnH, mostrando relações entre algumas espécies do gênero Attalea. Os valores significativos (maior que 50\%) de bootstrap (1.000 repetições) estão representados estão representados na árvore. Cocos nucifera (GQ435464.1) foi utilizado como outgroup. 


\section{PRK - MV}

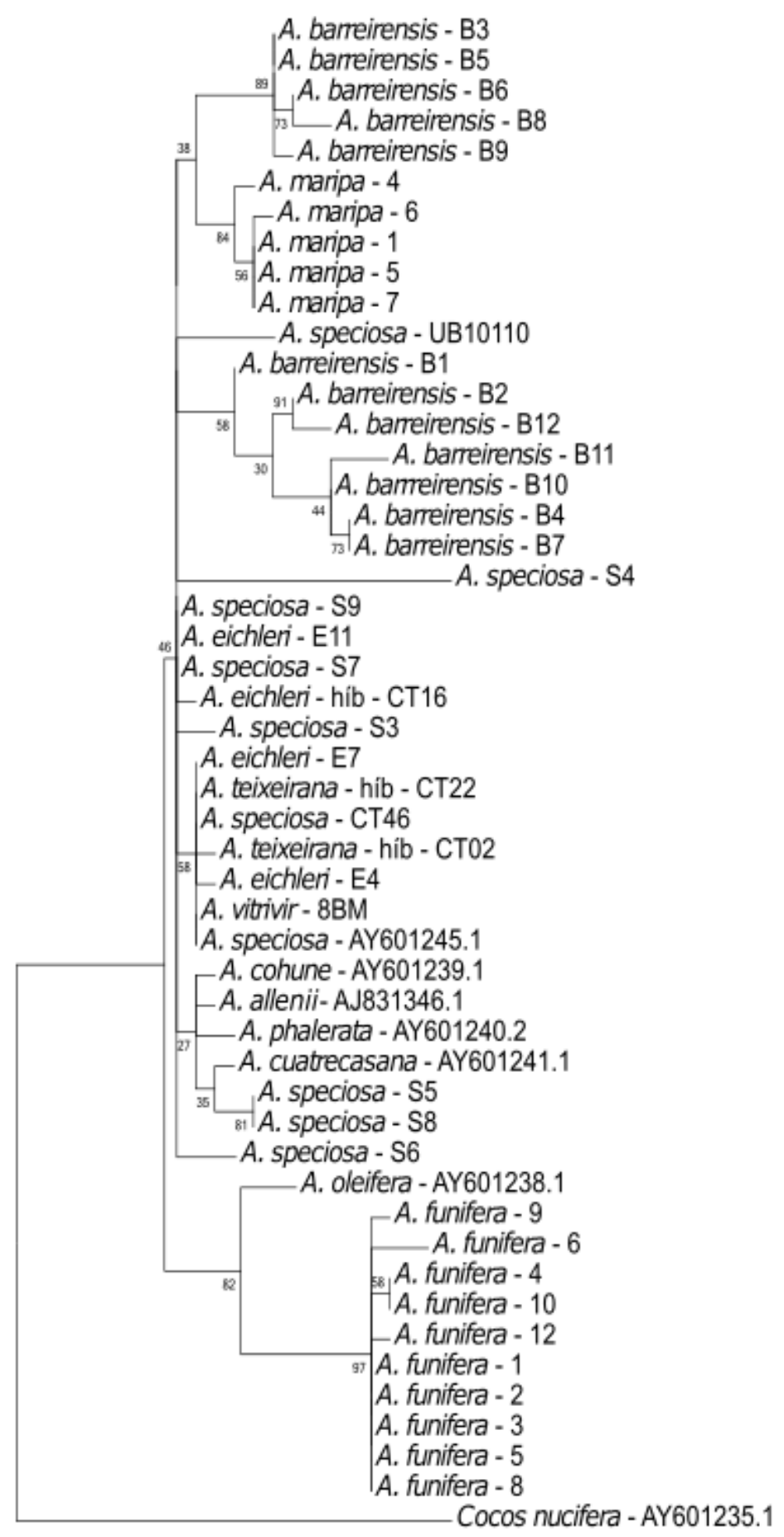

$\widehat{0.005}$

Figura 41. Árvore filogenética de Máxima Verossimilhança inferida a partir de sequências do gene PRK, mostrando relações entre algumas espécies do gênero Attalea. Os valores significativos (maior que $50 \%)$ de bootstrap (1.000 repetições) estão representados na árvore. Cocos nucifera (AY601235.1) foi utilizado como outgroup. 


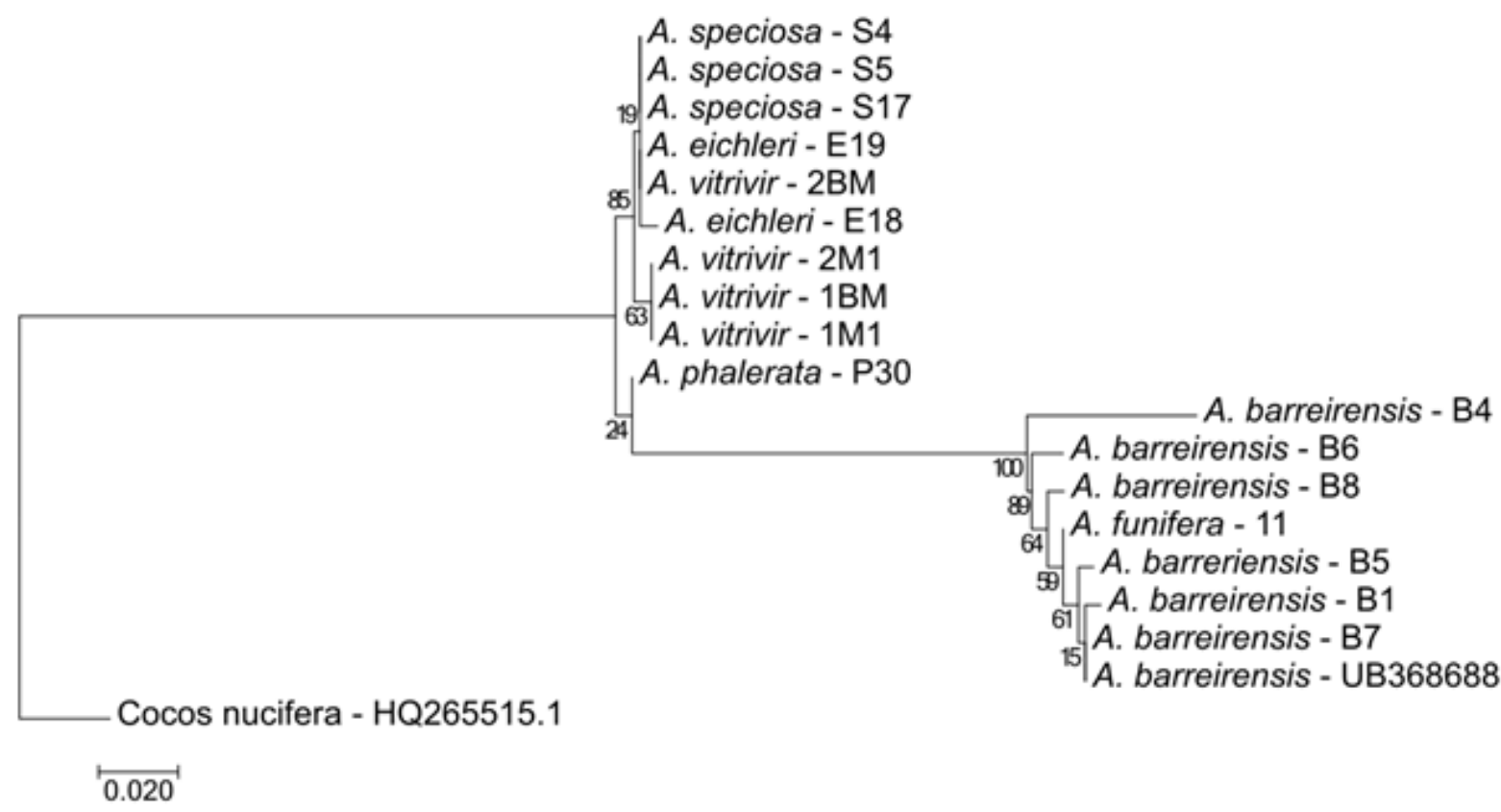

Figura 42. Árvore filogenética de Máxima Verossimilhança inferida a partir de sequências do gene ITS, mostrando relações entre algumas espécies do gênero Attalea. Os valores significativos (maior que 50\%) de bootstrap (1.000 repetições) estão representados na árvore. Cocos nucifera (HQ265515.1) foi utilizado como outgroup. 
Anexo V - Sequências das amostras de Attalea geradas pelos marcadores matK, $r b c L$, $\operatorname{trn} L$, $p s b A$-trnH, ITS e PRK.

Sequências de $m a t K$
10
$20 \quad 30$
60
80
90
100

A. eichleri - UB1091

A. phalerata - UB238

A. speciosa - UB10110

A. vitrivir - CEN10759

$A$. barreirensis - B15

A. barreirensis - B16
A. barreirensis - B17

A. eichleri - E18

A. eichleri - E19

A. funifera - 7

A. funifera - 10

A. funifera - 25

A. maripa - 10

A. maripa - 16

A. phalerata - P30

A. phalerata - P36

A. speciosa - S4

A. phalerata - HQ265548.1

A. butyracea - JQ586691.

A. rostrata - GQ981943.1

A. butyracea - JQ586690.1

A. allenii - AM114636.1
A. teixeirana - híb - BA1

A. teixeirana - híb - BA1
A. teixeirana - híb - BA39

A. teixeirana - híb - BA39

A. teixeirana - híb - СТ02

A. teixeirana - híb - CT22

A. teixeirana - híb - СТ 37

A. teixeirana- híb - СТ38

A. speciosa - CT46

A. speciosa - CT47

A. teixeirana - híb - LA19

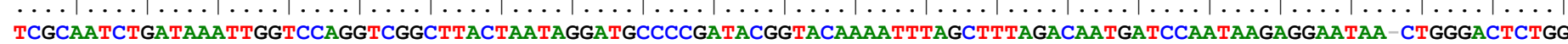

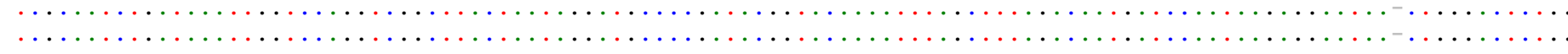


Continuação das sequências de matK
A. eichleri - UB1091
A. speciosa - UB10110
A. speciosa - UB10110
A. vitrivir - CEN10759
A. vitrivir - CEN 10759
A. barreirensis - B15
A. barreirensis - B15
A. barreirensis - B16
A. barreirensis - B1
A. eichleri - E18
A. eichleri - E19
A. funifera -7
A. funifera - 7
A. funifera - 10
A. funifera -10
A. funifera -25
A. maripa - 10
A. maripa - 15
A. maripa - 16
A. phalerata - P30
A. phalerata - P36
A. speciosa - S4
A. phalerata - HQ265548.1
A. butyracea - JQ586691.1
A. rostrata - GQ981943.1
A. rostrata - GQ981943.1
A. butyracea - JQ586690.
A. allenii - AM114636.1
A. teixeirana - híb - BA1
A. teixeirana - híb - BA1
A. teixeirana - híb - СТ01
A. teixeirana - híb - Ст02
A. teixeirana - híb - CT22
A. teixeirana - híb - СT37
A. teixeirana - híb - СТ38
A. speciosa - CT46
A. speciosa - CT47
A. teixeirana - híb - LA19
Cocos nucifera - HQ265564. $130 \quad 140$

150

160

170

180

190

200

210

220

TATCGAATTTTTTAATAAGAGTATCTATTAGAAATGAATTCTCTAGCGTTTGATTCCTTACCGCCGÄGATTTATTAGTACACTTGAAAGATAACCTAGAAAATAGAA

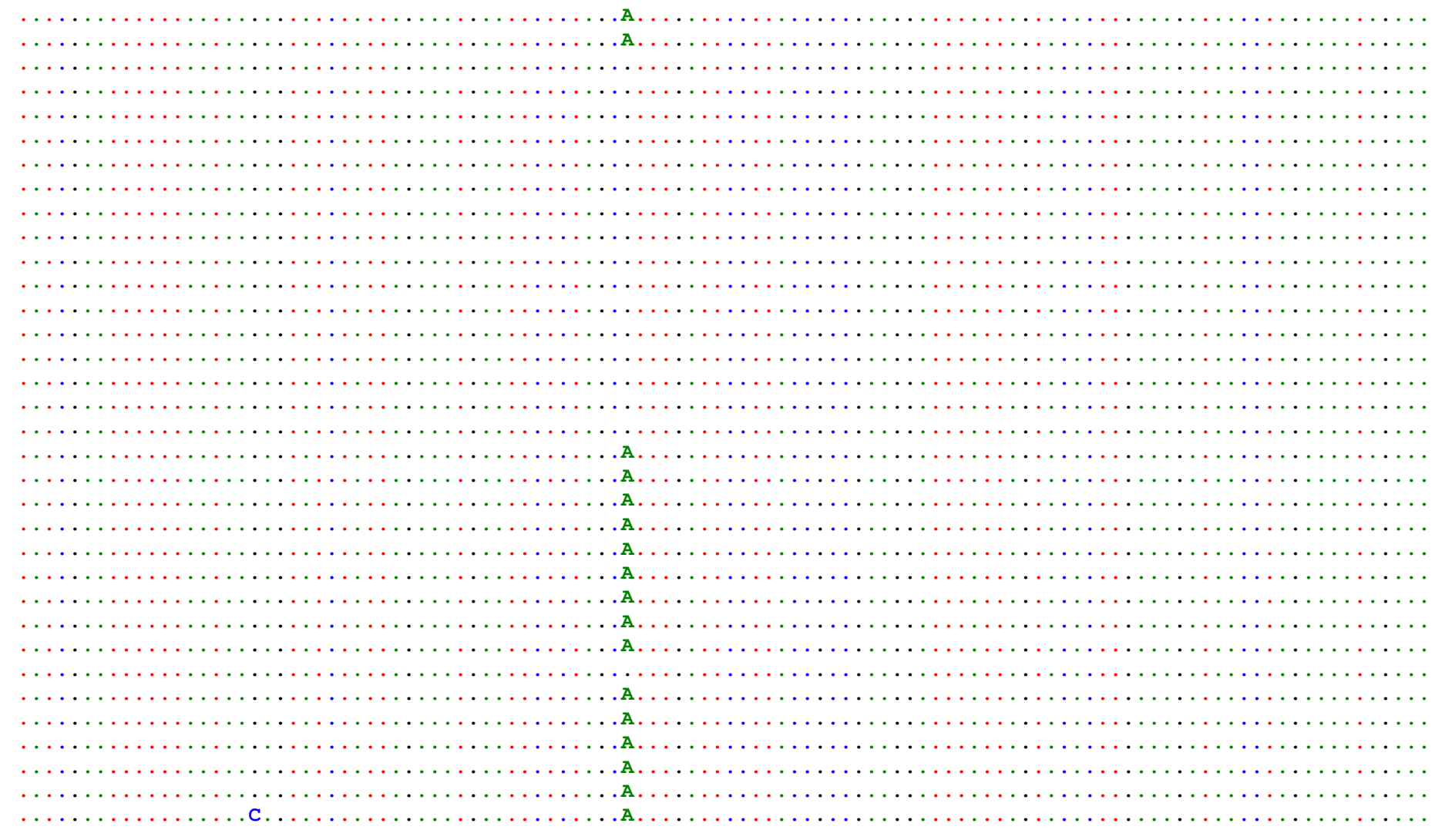


A. eichleri - UB1091

A. phalerata - UB238

A. vitrivir - CEN10759

Tir - CEN10759

A. barreirensis - B15

A. barreirensis - B16
A. barreirensis - B17

A. eichleri - E18

A. eichleri - E18
A. eichleri - E19

A. funifera - 7

A. funifera - 7

A. funifera - 10
A. funifera -25

A. maripa - 10

A. maripa - 15

A. maripa - 16

A. phalerata - P30

A. phalerata - P36

A. speciosa - S4

A. phalerata - HQ265548.1

A. butyracea - JQ586691.1

A. rostrata - GQ981943.1

A. butyracea - JQ586690.1

A. allenii - AM114636.1

A. allenii - AM114636.1
A. teixeirana - híb - BA1

A. teixeirana - híb - BA1

A. teixeirana - híb - BA39
A. teixeirana - híb - СТ01

A. teixeirana - híb - СТ02

A. teixeirana - hib - CT02

A. teixeirana - híb - СT37

A. teixeirana - híb - СТ38

A. speciosa - СТ46

A. speciosa - СТ4 7

A. teixeirana - híb - LA19

Cocos nucifera - HQ265564.1
GAACAGCTTGATAATTGGTTTATATGGATCCTGTACGGTTGAGACCAAAATGAAAATAATATTGCCAGAAATTGACAAGATGACATTTCCATTTCTTCATCAGAGATG

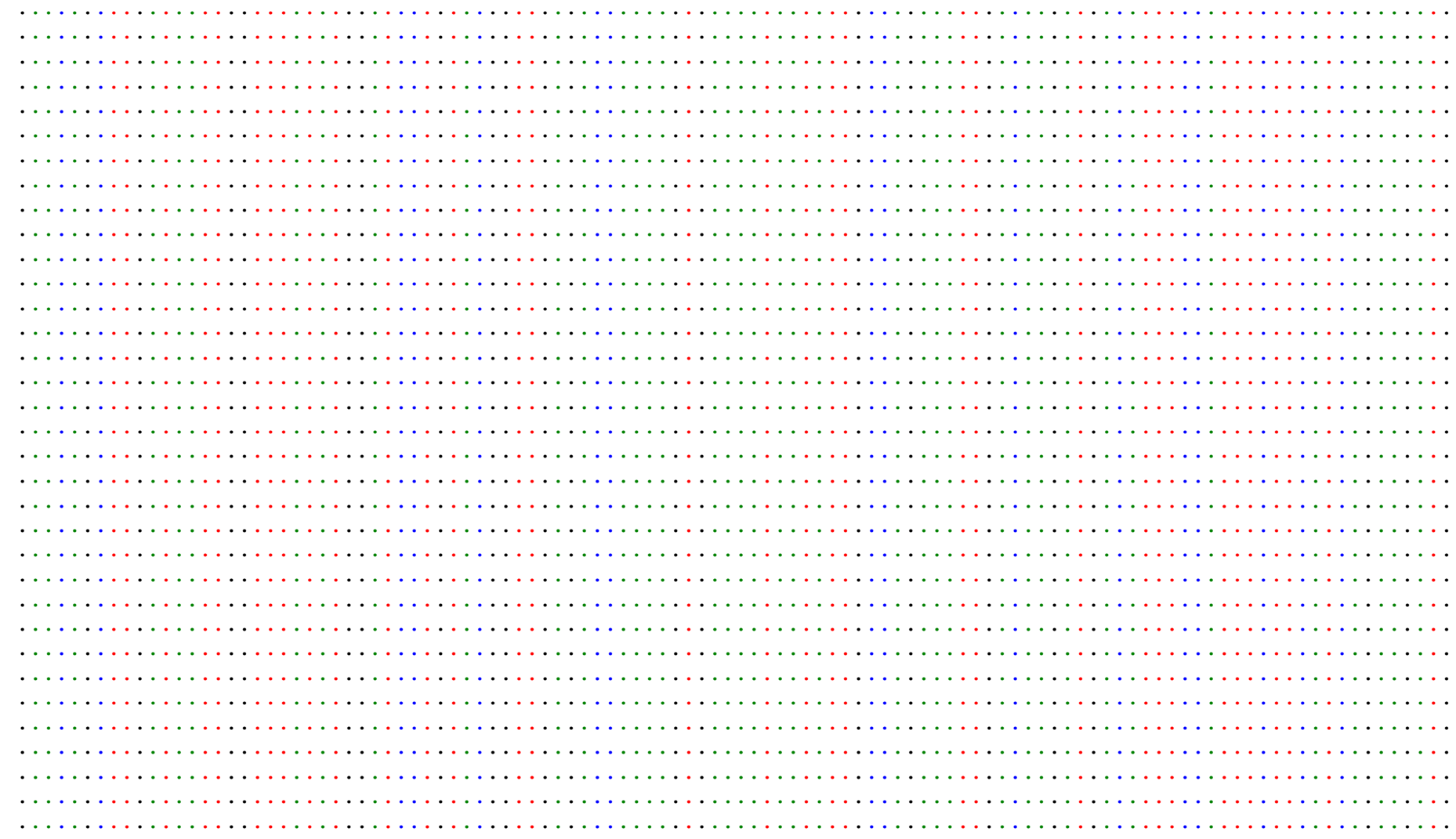


34

A. eichleri - UB1091

A. phalerata - UB238

A. speciosa - UB10110

A. barreirensis - B15

A. barreirensis - B16
A. barreirensis - B17

A. eichleri - E18

A. eichleri - E19

A. funifera - 7

A. funifera - 10

A. funifera -25

A. funifera -10

A. maripa - 10
A. maripa - 15

A. maripa - 16

A. phalerata - P30

A. phalerata - P36

A. speciosa - S4

A. phalerata - HQ265548.1

A. butyracea - JQ586691.1

A. rostrata - GQ981943.1

A. butyracea - JQ586690.1

A. allenii - AM114636.1

A. teixeirana - híb - BA1

A. teixeirana - híb - BA39

A. teixeirana - híb - BA39
A. teixeirana - híb - СТ01

A. teixeirana - híb - СТ01

A. teixeirana - híb - СТ22

A. teixeirana - híb - СТ22
A. teixeirana - híb - СT37

A. teixeirana - híb - СТ38

A. speciosa - СT46

A. speciosa - CT47

A. teixeirana - híb - LA19

Cocos nucifera - HQ265564.
AGTCCCCTTTGAAACCAGAATTGCTTTTCCTTGATATCGAACATAATGCATGAAGGGATCCTTGAAGAACCATAGGGTCTTCTGAAAATAATTACGGCGCACTACTATAA

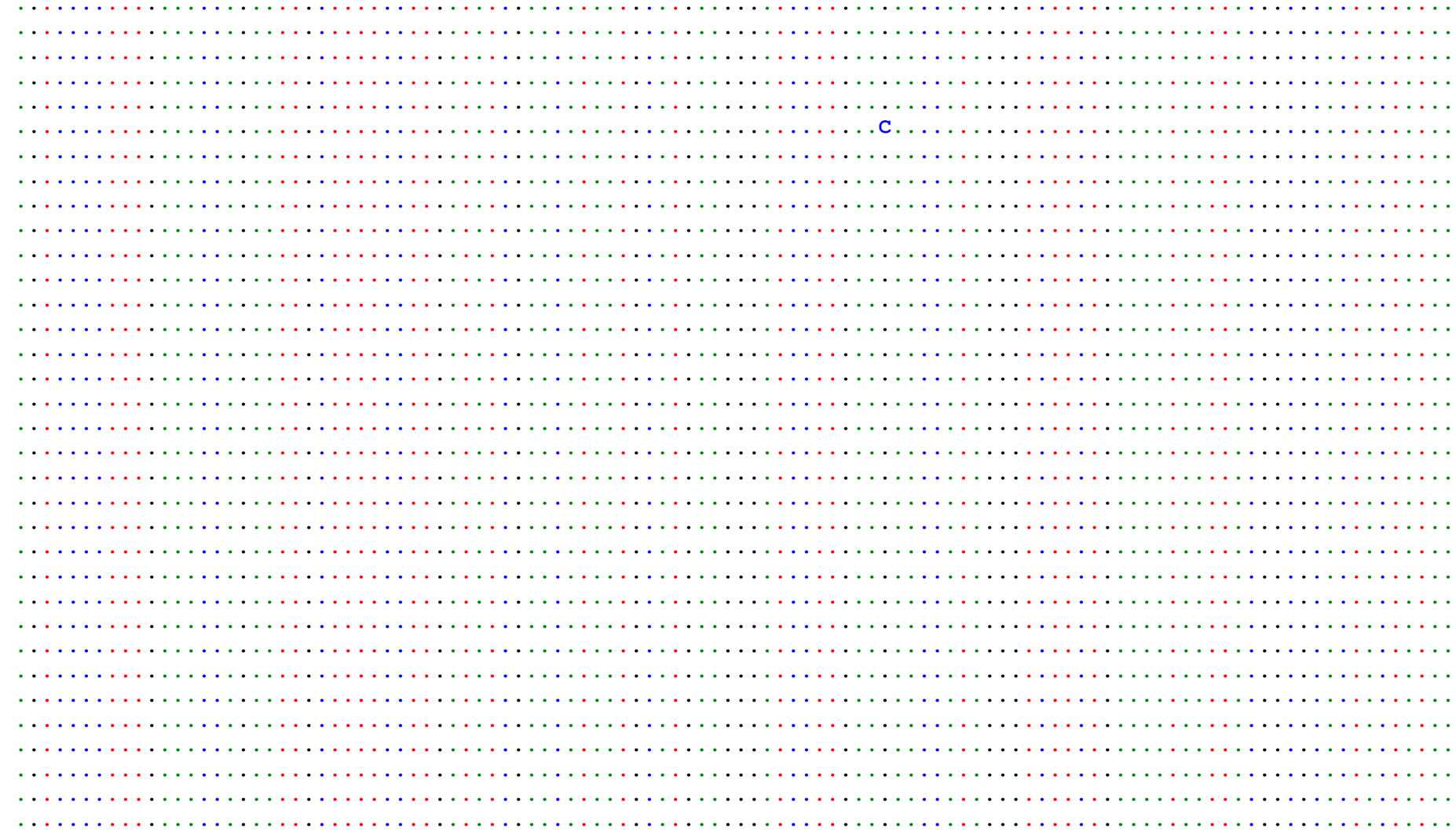


A. eichleri - UB1091

A. phalerata - UB238

A. vitrivir - CEN10759

A. barreirensis 10759

A. barreirensis - B15

A. barreirensis - B16
A. barreirensis - B17

A. eichleri - E18

A. eichleri - E19

A. funifera - 7

A. funifera - 10
A. funifera -25

A. funifera -25
A. maripa -10

A. maripa - 10
A. maripa - 15

A. maripa - 16

A. phalerata - P30

A. phalerata - P36

A. speciosa - S4

A. phalerata - HQ265548.1

A. butyracea - JQ586691.1

A. rostrata - GQ981943.1

A. butyracea - JQ586690.1

A. allenii - AM114636.1

A. allenii - AM114636.1
A. teixeirana - híb - BA1

A. teixeirana - híb - BA1

A. teixeirana - híb - BA39
A. teixeirana - híb - СТ01

A. teixeirana - híb - CT02

A. teixeirana - híb - СТ02

A. teixeirana - híb - СТ 37

A. teixeirana - híb - СТ38

A. speciosa - СТ46

A. speciosa - СТ4 7

A. teixeirana - híb - LA19

Cocos nucifera - HQ265564.
GATGTTCTATTTTTCCATAGAAATGTGTTGCTCAAGAAAAGCTCAGA GATGTTAATCGTAAATAAGAAGATTGTTTACGAAGAAAAACTAATACAAATTCGCATTCA

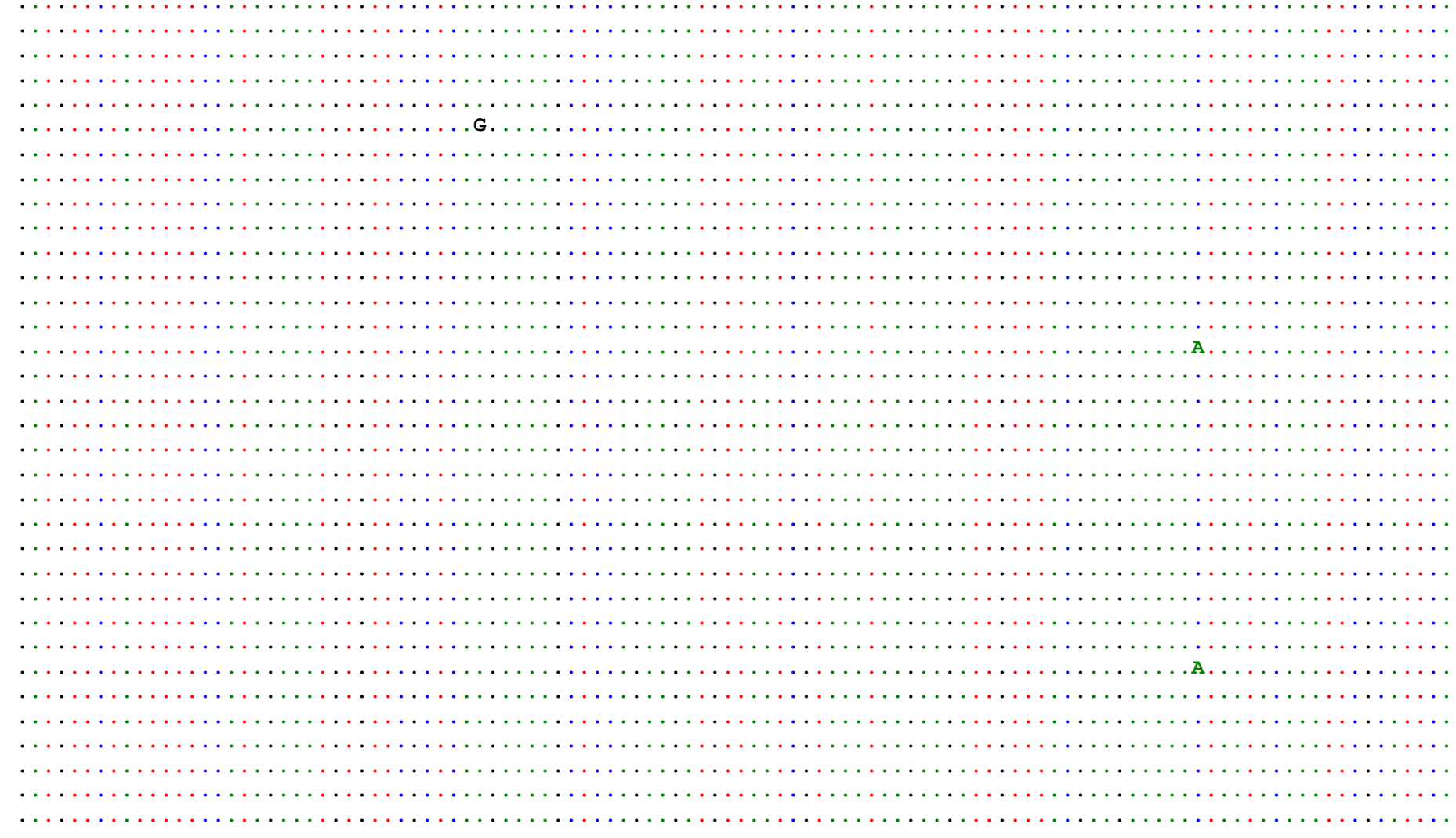


Continuação das sequências de matK
A. eichleri - UB1091
A. phalerata - UB238
A. Speciosa - UB10110
A. barreirensis - B15
A. barreirensis - B15
A. barreirensis - B17
. eichleri - E18
. eichleri - E19
. funifera - 7
A. funifera -10
A. funifera -25
A. maripa -10
A. maripa - 10
A. maripa - 15
A. maripa - 16
A. phalerata - P30
A. phalerata - P36
speciosa - S4
A. phalerata - HQ265548.1
A. butyracea - JQ586691.1
A. rostrata - GQ981943.1
A. butyracea - JQ586690.1
A. butyracea - JQ586690.1
A. teixeirana - híb - BA1
A. teixeirana - híb - BA39
A. teixeirana - híb - СT01
A. teixeirana - híb - СТ02
A. teixeirana - híb - СT22
A. teixeirana - híb - СT37
A. teixeirana - híb - CT38
A. speciosa - СТ46
A. speciosa - CT47
A. teixeirana - híb - LA19
Cocos nucifera - HQ265564.1

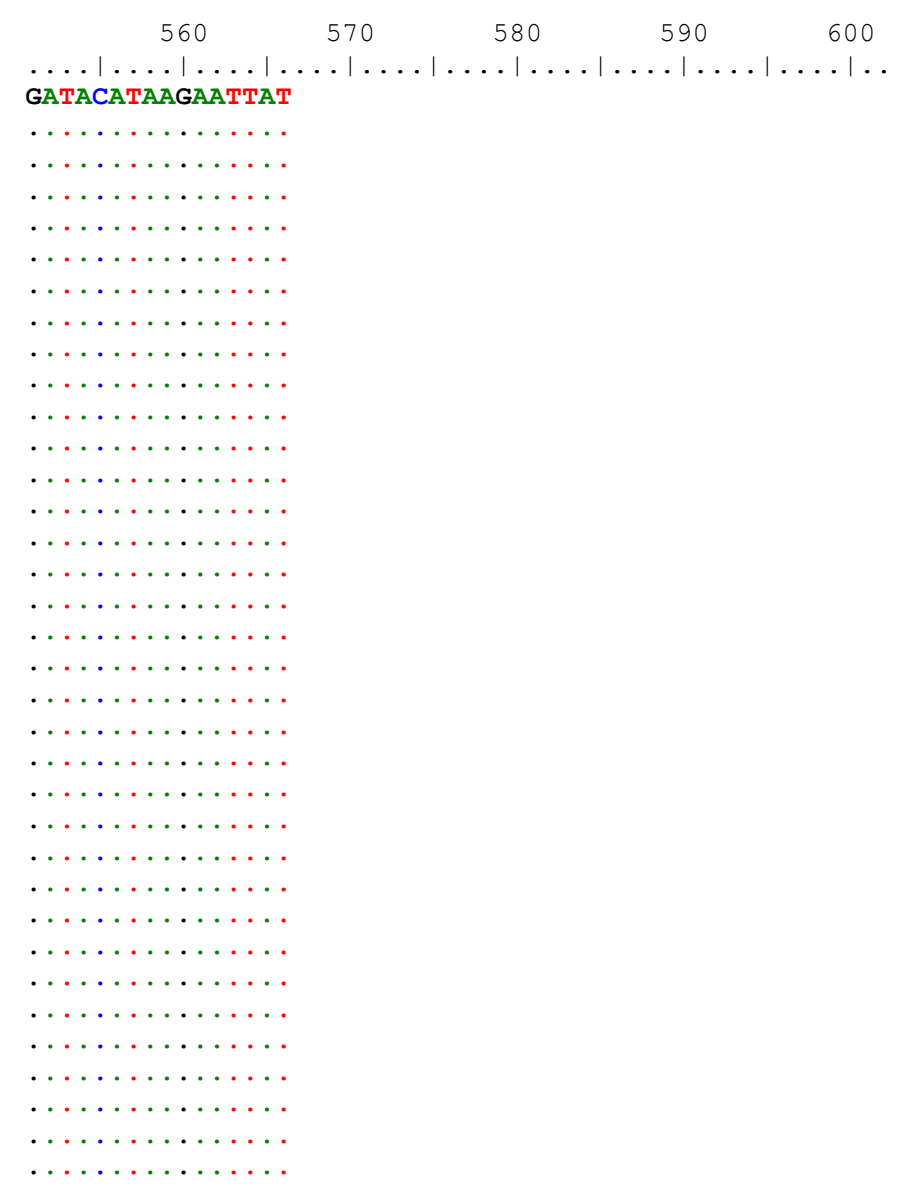


Sequências de $r b c L$

30

40

50

60

70

80

90

100

110

GATTACAAATTGACTTATTATACTCCTGACTACGAAACCAAAGATACTGATATCTTGGCAGCATTCCGAGTAACTCCTCAACCCGGAGTTCCG-CCTGAGGAAGCAGGG

A. eichleri - UB1091

A. phalerata - UB238
A. speciosa - UB10110

A. speciosa - UB10110
A. barreirensis - UB36868

A. barreirensis - UB368
A. speciosa - CEN58039

A. speciosa - CEN58039

A. barreirensis - B15

A. barreirensis - B16

$A$. barreirensis - B17

A. eichleri - E17

A. eichleri - E18

A. eichleri - E19

A. funifera -7

A. maripa - 10

A. maripa - 15

A. phalerata - P12

A. phalerata - P30

A. phalerata - P36

A. phalerata - $\mathrm{P} 36$

A. speciosa - S5
A. speciosa - S4

A. Speciosa - S4
A. allenii - AJ404829.1

A. butyracea - JQ590420.1

A. butyracea - JQ590420.1

A. rostrata - GQ981675.1

A. teixeirana - híb - BA1

A. teixeirana - híb - BA4

A. teixeirana - híb - СT01

A. teixeirana - híb - СT02

A. teixeirana - híb - CT20

A. teixeirana - híb - CT37

A. teixeirana - híb - СT22

A. teixeirana - híb - СT38

A. speciosa - CT46

Cocos nucifera - AY012507.1

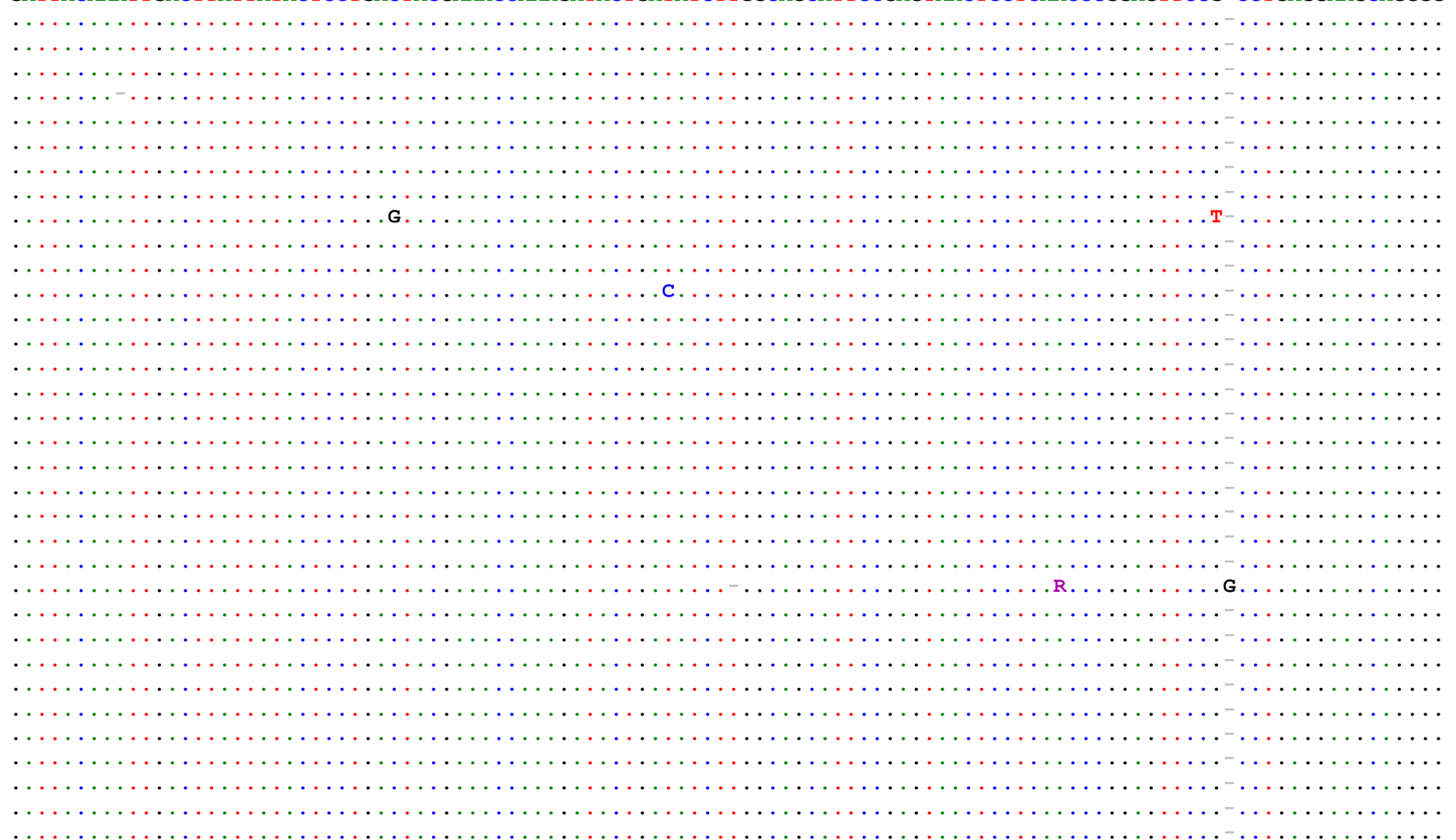


Continuação das sequências de $r b c L$

A. eichleri - UB1091

A. phalerata - UB238

A. speciosa - UB10110

A. barreirensis - UB36868

A. speciosa - CEN58039

A. maripa - CEN12546

A. barreirensis - B15

A. barreirensis - B16

A. barreirensis - B17

A. eichleri - E17

A. eichleri - E18
A. eichleri - E19

A. eichleri - E19

A. funifera -
A. maripa - 10

A. maripa - 15

A. maripa - 15

A. phalerata - P30

A. phalerata - P36

A. speciosa - S5
A. speciosa - S4

A. speciosa - S4
A. allenii - AJ404829.1

A. butyracea - JQ590420.1

A. rostrata - GQ981675.1

A. teixeirana - híb - BA1

A. teixeirana - híb - BA4

A. teixeirana - híb - BA39

A. teixeirana - híb - СТ01

A. teixeirana - híb - СT02

A. teixeirana - híb - CT20

A. teixeirana - híb - СT37
A. teixeirana - híb - CT22

A. teixeirana - híb - СT22

A. speciosa - СT46

A. eichleri - ES22

Cocos nucifera - AY012507.1

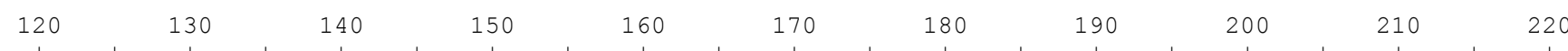
CAGCGGTAGCTGCCGAATCTTCTACTGGTACATGGACAACTGTGTGGACT GATGGACTTACCAGTCTTGATCGTTACAAAGGACGATGCTACCACATCGAAACCGTTGTC 
Continuação das sequências de $r b c L$

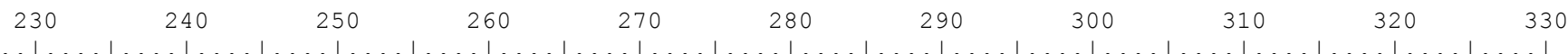

A. eichleri - UB1091

A. phalerata - UB238

A. speciosa - UB10110
A. barreirensis - UB36868

A. barreirensis - UB36868
A. speciosa - CEN58039

A. speciosa - CEN58039

A. maripa - CEN12546
A. barreirensis - B15

A. barreirensis - B15
A. barreirensis - B16

A. barreirensis - B17

A. eichleri - E17

A. eichleri - E18

A. eichleri - E19

A. funifera - 7

A. maripa - 10

A. phalerata - P12

A. phalerata - P30

A. phalerata - P36

A. phalerata - $\mathrm{P} 5$

A. speciosa - S5
A. speciosa - S4

A. Speciosa - S4

A. allenii - AJ404829.1

$A$. butyracea - JQ590420.1
$A$. rostrata - GQ981675.1

A. teixeirana - híb - BA1

A. teixeirana - híb - BA4
A. teixeirana - híb - BA39

A. teixeirana - híb - BA39
A. teixeirana - híb - СТ01

A. teixeirana - híb - СT0

A. teixeirana - híb - CT20

A. teixeirana - híb - СT37

A. teixeirana - híb - Ст22

A. teixeirana - híb - СТ38

A. speciosa - СТ46

Cocos nucifera - AY012507.1

GGGGAGGAAAATCAATATATTGCTTATGTAGCCTATCCTTTAGACCTTTTTGAAGAAGTTCTGTTACTAACATGTTTACTTCCATTGTGGGTAATGTATTTGGTTTCAA

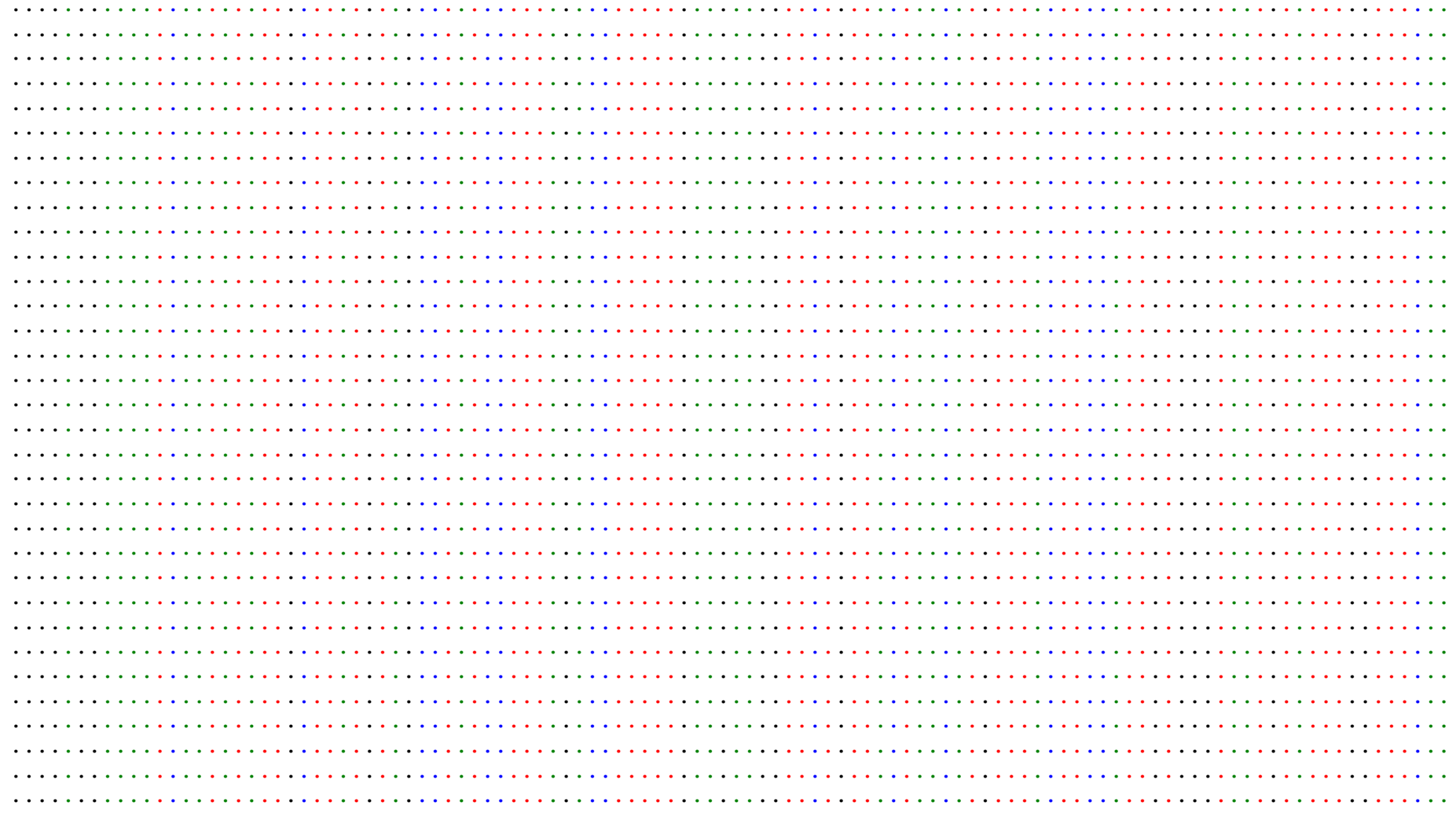




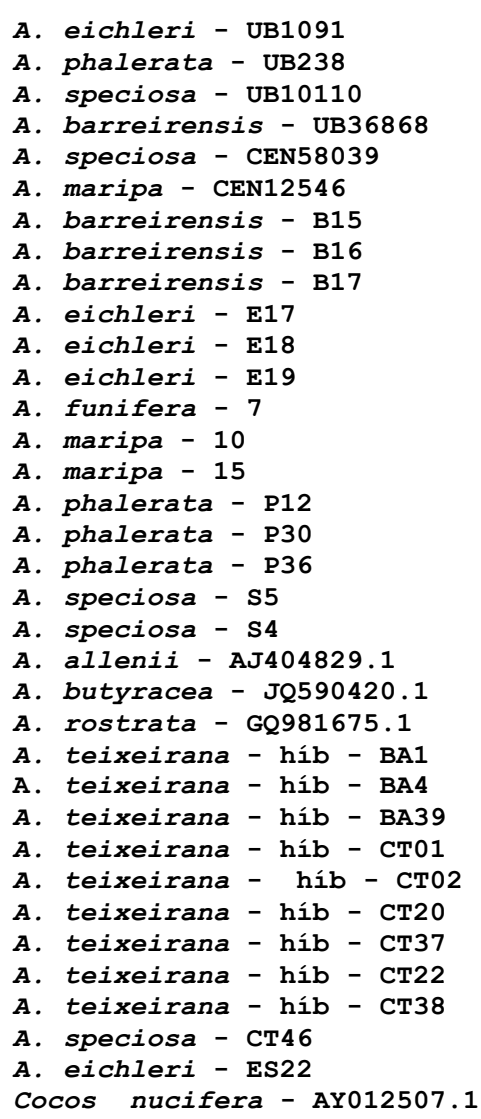

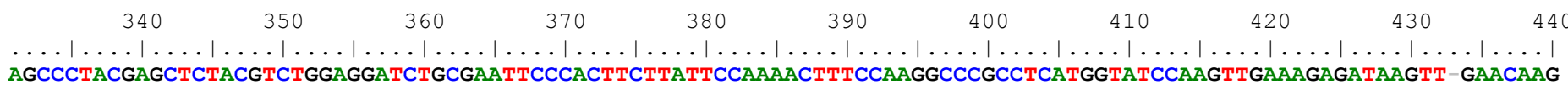

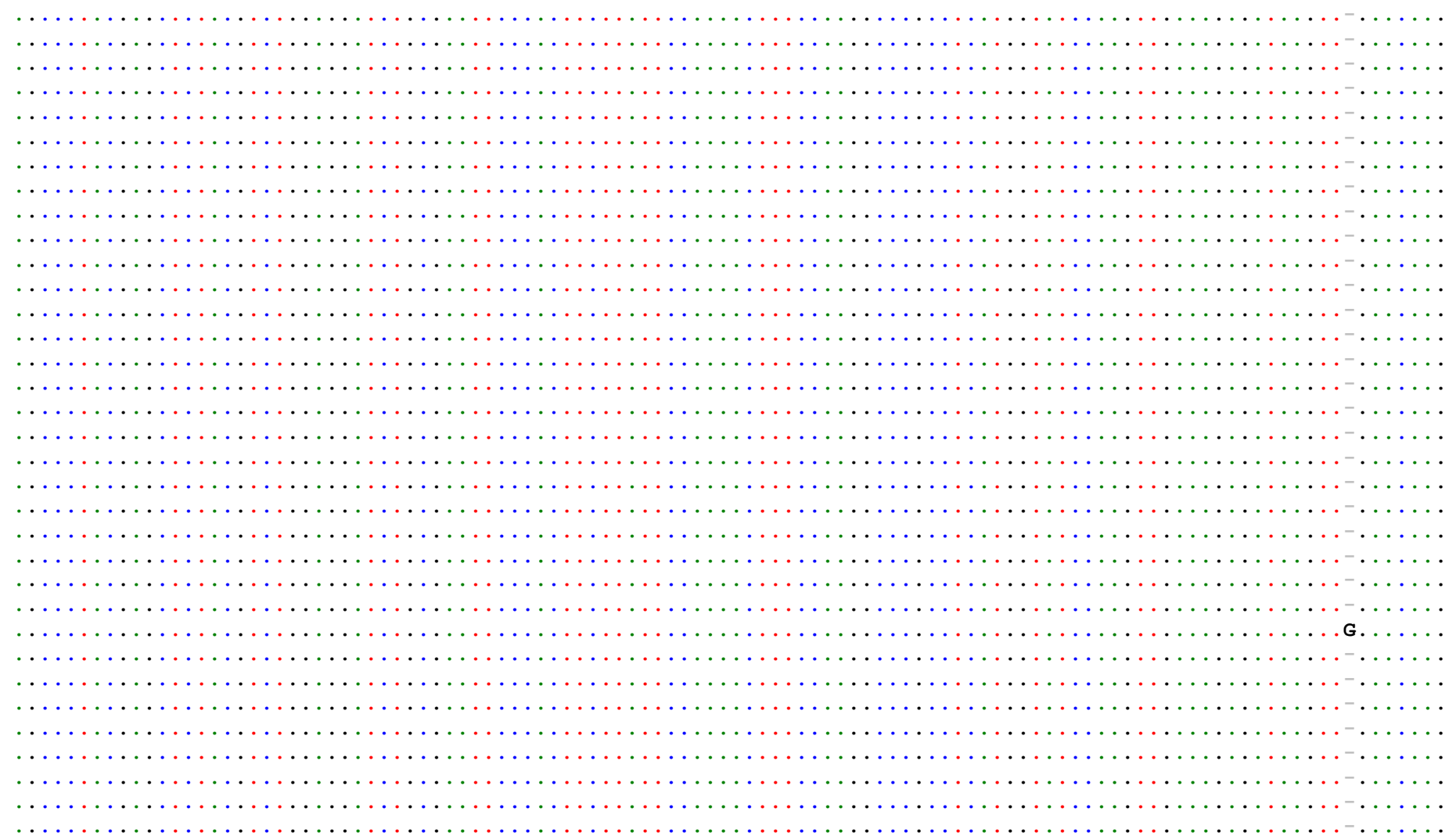


Continuação das sequências de $r b c L$

$\begin{array}{lllll}450 & 460 & 470 & 480 & 490\end{array}$

A. eichleri - UB1091

A. phalerata - UB238

A. speciosa - UB10110
A. barreirensis - UB36868

A. barreirensis - UB368
A. speciosa - CEN58039

A. speciosa - CEN58039
A. maripa - CEN12546

A. maripa - CEN12546

A. barreirensis - B15
A. barreirensis - B16

A. barreirensis - B17

A. eichleri - E17

A. eichleri - E18
A. eichleri - E19

A. eichleri - E19
A. funifera - 7

A. funifera -7

A. maripa - 15

A. phalerata - P12

A. phalerata - P30

A. phalerata - P36

A. speciosa - S5

A. speciosa - S4
A. allenii - AJ404829.

A. allenii - AJ404829.1

A. rostrata - GQ981675.1

A. teixeirana - híb - BA1

A. teixeirana - hib - BA4

A. teixeirana - híb - BA39

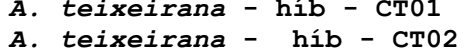

A. teixeirana - híb - СT02

A. teixeirana - híb - СТ20
A. teixeirana - híb - СТ 37

A. teixeirana - híb - СT22

A. teixeirana - híb - CT38

A. speciosa - СТ46

A. eichleri - ES22

Cocos nucifera - AY012507.1

TATGGTCGTCCT-CTATTGGGATGTACTATTAAACCAAAATTGGGATTA

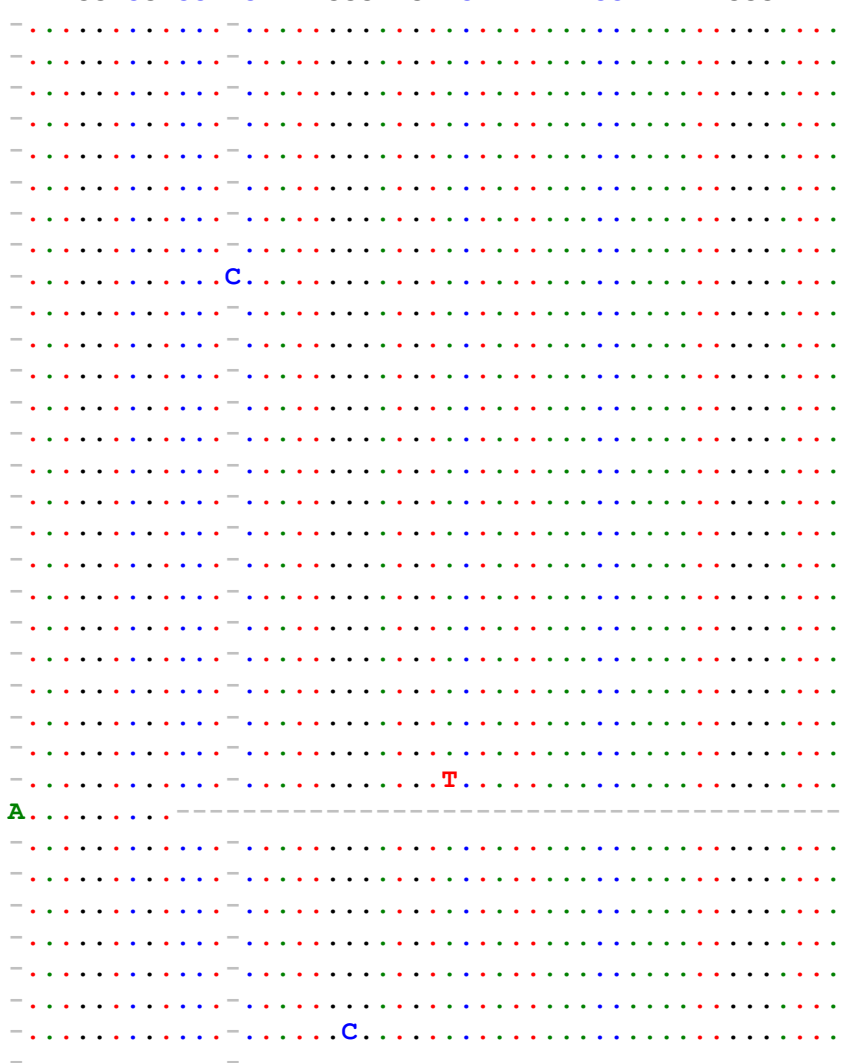



A. barreirensis - B15
A. eichleri - E18
A. eichleri - E19
A. maripa - 10
A. phalerata - P12
A. phalerata - P12
A. phalerata - P30
A. phalerata - P30
A. phalerata - P36
A. phalerata - $\mathrm{P} 3$
A. Speciosa - S4
A. speciosa - S5
A. speciosa - S17
A. barreirensis - UB36868
A. barreirensis - CEN52072
A. eichleri - UB1091
A. phalerata - UB238
A. speciosa - UB10110
A. vitrivir - CEN10759
A. barreirensis - B17
A. crassispatha - AJ241321.1
A. phalerata - HQ265783.1
A. allenii - AJ241312.1
A. teixeirana - híb - BA1
A. teixeirana - híb - СT01
A. teixeirana - híb - СТ02
A. eichleri - СТ07
A. teixeirana - híb - СТ20
A. teixeirana - híb - СT22
A. teixeirana - híb - СТ37
A. speciosa - CT46
A. speciosa - CT47
Aocos nucifera - AM113647.1

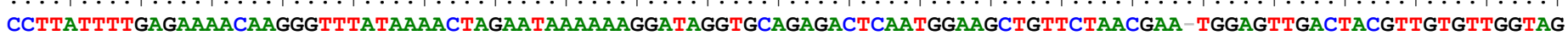

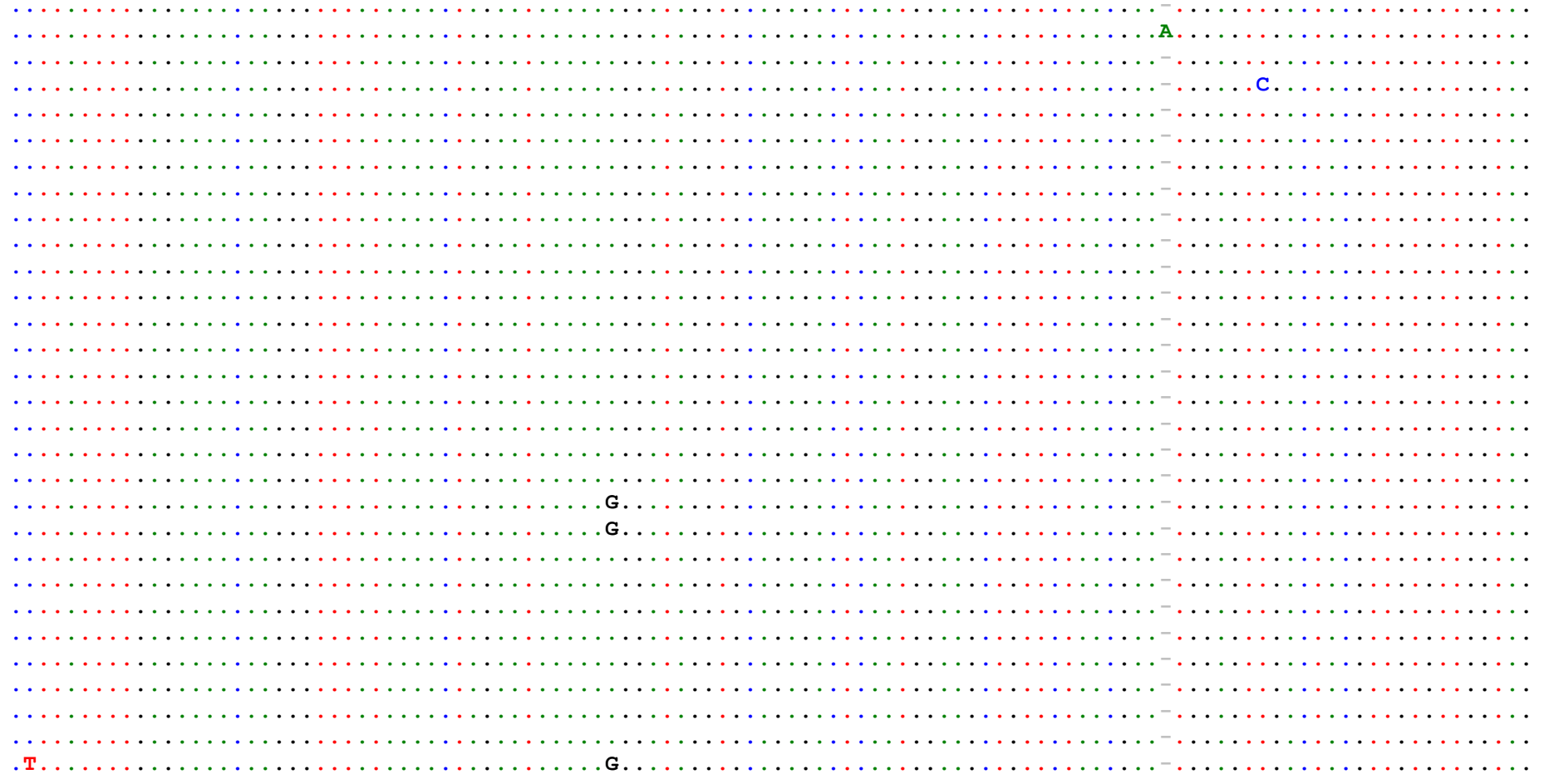


Continuação das sequências de $\operatorname{trn} L$

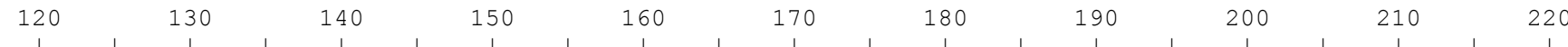

A. barreirensis - B15

A. barreirensis - B1

A. eichleri - E18

A. eichleri - E19

A. maripa - 10

A. phalerata - P12
A. phalerata - P30

A. phalerata - P36

A. phalerata - $\mathrm{P} 36$

A. speciosa - S5

A. speciosa - S17
A. barreirensis - UB 36868

A. barreirensis - CEN52072

A. eichleri - UB1091

A. phalerata - UB238

A. speciosa - UB10110

A. vitrivir - CEN10759

A. barreirensis - B17

A. crassispatha - AJ241321.1

A. phalerata - HQ265783.1

A. allenii - AJ241312.1

A. teixeirana - híb - BA1

A. teixeirana - híb - BA1

A. teixeirana - híb - СТ01

A. teixeirana - híb - СТ02

A. teixeirana - híb - СT20

A. teixeirana - híb - СT22

A. teixeirana - híb - СТ37

A. speciosa - CT46
A. speciosa - CT47

Aocos nucifera - AM113647.1

CTGGAA-тTCCTCTATCG-AAATTACA GAAAGGACGCCCTATATAATATATCTAATACGTACGTATACATACTAACATATCAAACGATTAATCACGACCCGATCTATC

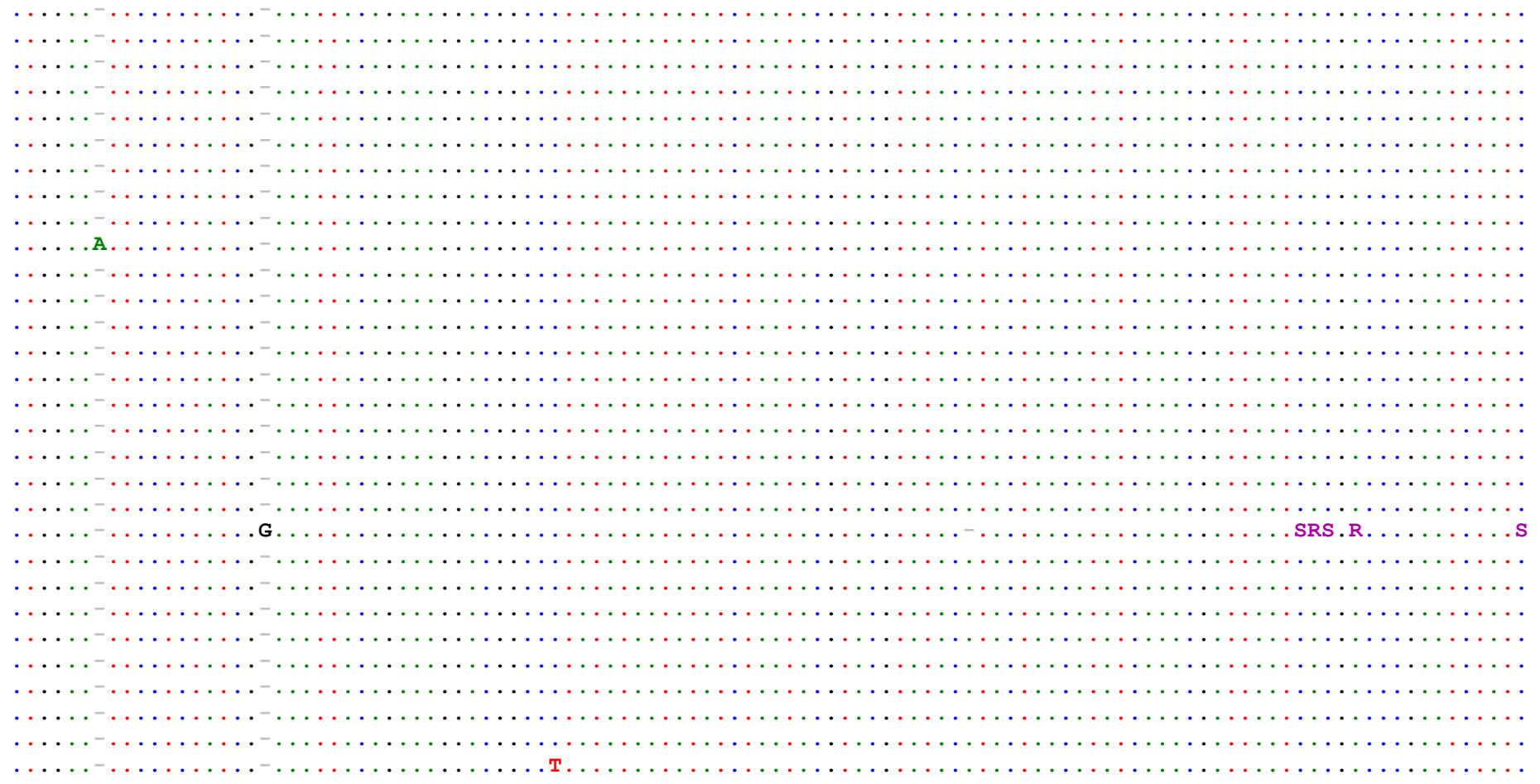


Continuação das sequências de $\operatorname{trn} L$
A. barreirensis - B15
A. barreirensis - B1
A. eichleri - E18
A. eichleri $-\mathbf{E}$
A. maripa - 10
A. phalerata - P12
A. phalerata - P30
A. phalerata - P36
A. phalerata - $\mathrm{P} 36$
A. speciosa - S5
A. speciosa - S17
A. barreirensis - UB36868
A. barreirensis - CEN52072
A. eichleri - UB1091
A. phalerata - UB238
A. speciosa - UB10110
A. vitrivir - CEN10759
A. crassispatha - AJ241321.1
A. phalerata - HO265783 1
A. allenii - AJ241312
A. teixeirana - híb - BA1
A. teixeirana - híb - BA1
A. teixeirana - híb - Ст01
A. teixeirana - híb - Ст02
A. teixeirana - híb
A. teixeirana - híb - Ст20
A. teixeirana - híb - Ст20
A. teixeirana - híb - Ст22
A. teixeirana - híb - CT37
A. speciosa - СТ46
A. speciosa - CT47
Cocos nucifera - AM113647.1

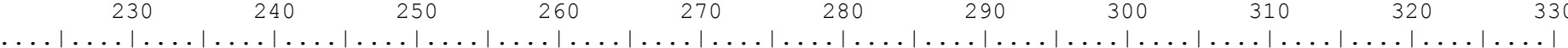

GAA- TATATATATATGAAAGAAAAAATTCAGAGTTATTGTGA- TCCATTCCAATCGAAGTTGAAGGAGAATCGAATATTCAGTGATCAAATCATTCATTCCAGAG

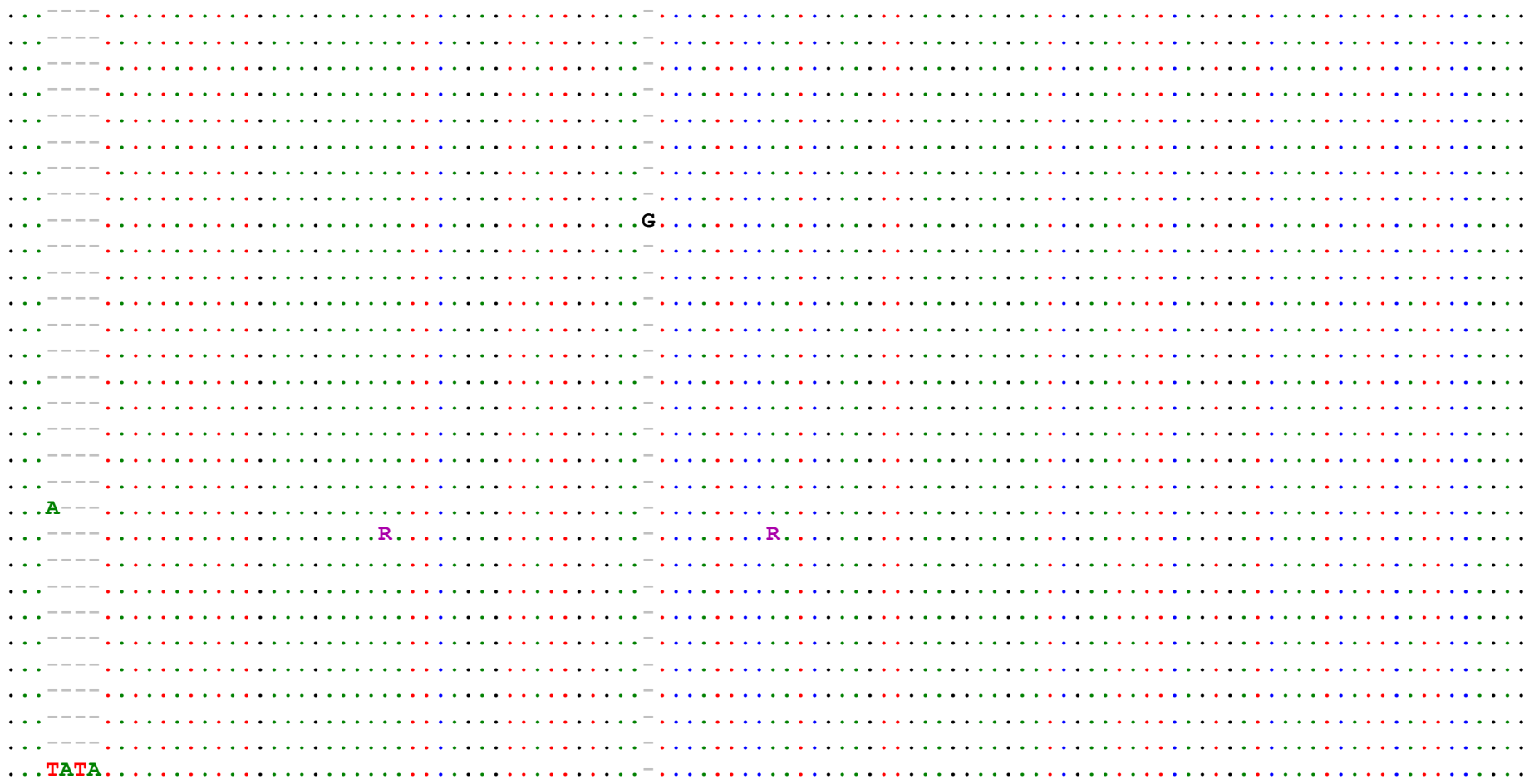


Continuação das sequências de $\operatorname{trn} L$

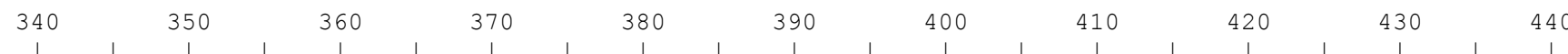

A. barreirensis - B15

A. barreirensis - B16

A. eichleri - E18

A. eichleri - $\mathbf{E}$

A. maripa - 10

A. phalerata - P30

A. phalerata - P36

A. speciosa - $\mathrm{S4}$

A. speciosa - S5

A. speciosa - S17

A. barreirensis - UB36868

A. barreirensis - CEN52072

A. eichleri - UB1091

A. phalerata - UB238

A. speciosa - UB10110

A. vitrivir - CEN10759

A. vitrivir - CEN10759
A. barreirensis - B17

A. barreirensis - B17
A. crassispatha - AJ241321.1

A. phalerata - HQ265783.1

A. allenii - AJ241312.1

A. teixeirana - híb - BA1
A. teixeirana - híb - СТ01

A. teixeirana - híb - Ст02

A. eichleri - СТ07

A. teixeirana - híb - Ст20

A. teixeirana - híb - CT22

A. teixeirana - híb - CT37

A. speciosa - CT46
A. speciosa - СT47

Cocos nucifera - AM113647.1

TTTGATAGATCTTTTGAAAAACTGATTAATCGGACGAGAATAAAGAGAGA GTCCGTTCTACATGTCAATACCGACAACAATGAAATTTATAGTAAGAGGAAAATCCGTC
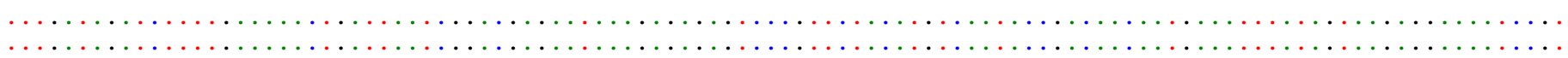

A. barreirensis - B15
A. barreirensis - B1
A. eichleri - E18
A. maripa - 10
A. phalerata - P12
A. phalerata - P30
A. phalerata - P36
A. speciosa - 54
A. speciosa - S5
A. speciosa - S17
A. speciosa - S17
A. barreirensis - UB36868
A. barreirensis - CEN52072
A. eichleri - UB1091
A. phalerata - UB238
A. speciosa - UB10110
A. barreirensis - B17
A. crassispatha - AJ241321.1
A. phalerata - HQ265783.1
A. allenii - AJ241312.1
A. teixeirana - híb - BA1
A. teixeirana - híb - BA1
A. teixeirana - híb - СТ01
A. teixeirana - híb - СT02
A. teixeirana - híb
A. teixeirana - híb - Ст20
A. teixeirana - híb - СT20
A. teixeirana - híb - CT22
A. teixeirana - híb - СТ 37
A. speciosa - CT46
A. speciosa - CT47
A. speciosa - CT47
Cocos nucifera - AM113647.1

450 460

GACTTTAGAAATCGTGAGGGTTCAAGTCC

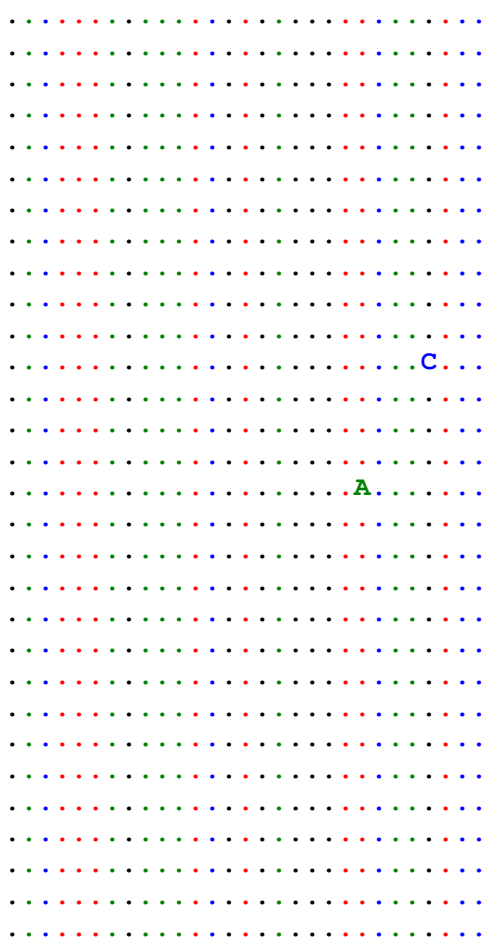



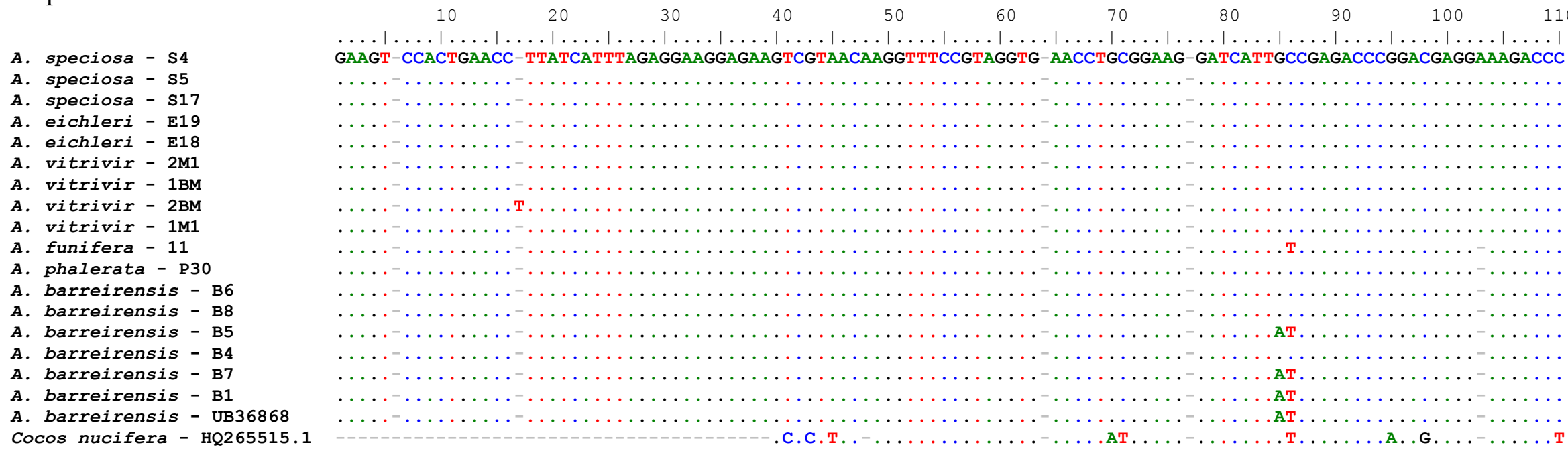

Continuação das sequências de ITS
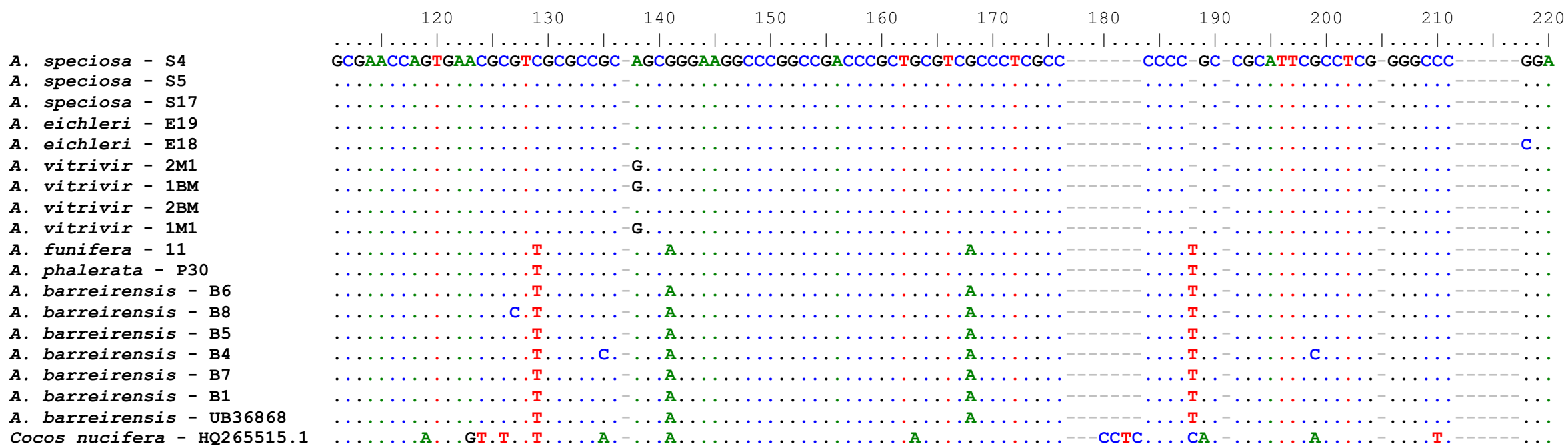
Continuação das sequências de ITS

$\begin{array}{llllllllll}230 & 240 & 250 & 260 & 270 & 280 & 290 & 300 & 310 & 320\end{array}$

A. speciosa - $\mathrm{S4}$

A. speciosa - S5

A. Speciosa - S17

A. eichleri - E19

A. eichleri - E18

A. vitrivir - 2M1

A. vitrivir - 1BM
A. vitrivir - 2BM

A. vitrivir - 1M1

A. funifera - 11
A. phalerata - P30

A. phalerata - P30
A. barreirensis - B6

A. barreirensis - B8

A. barreirensis - B5

A. barreirensis - B4

A. barreirensis - B7

A. barreirensis - UB36868

Cocos nucifera - HQ265515. 1

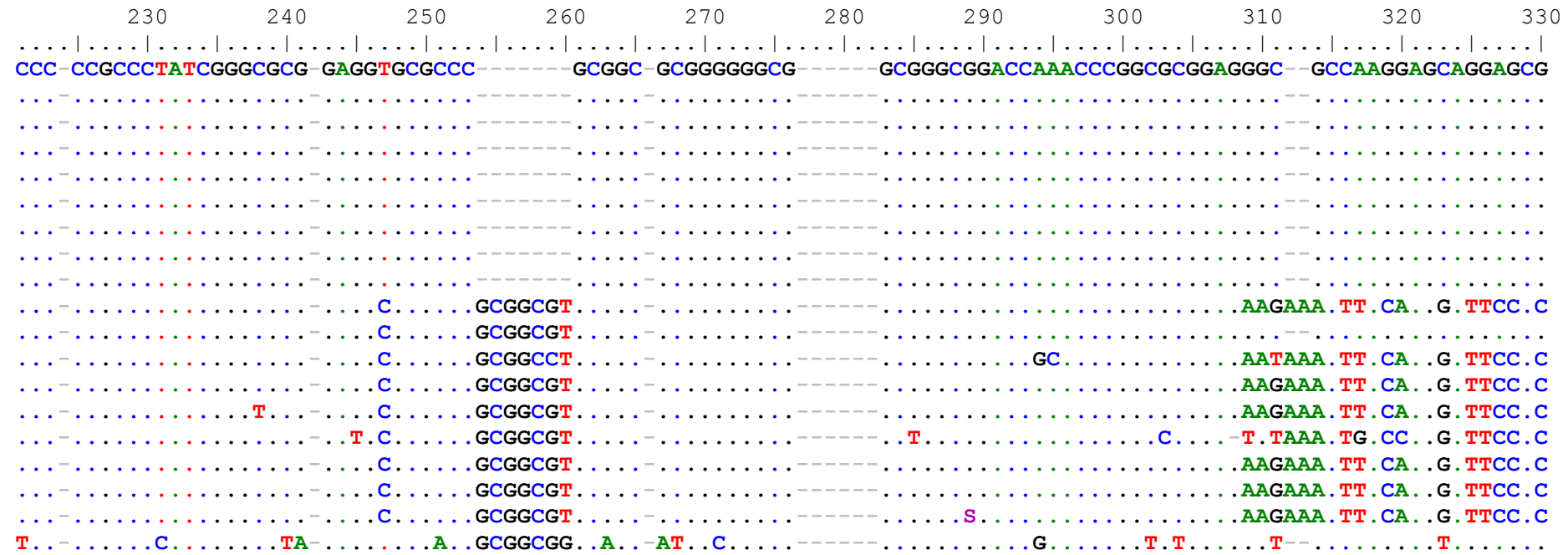

Continuação das sequências de ITS
A. speciosa - S4
A. speciosa - S5
A. speciosa - S17
A. eichleri - E19
A. eichleri - E18
A. vitrivir - 2M1
A. vitrivir - 1BM
A. vitrivir - 2BM
A. vitrivir - 1M1
A. funifera - 11
A. funifera - 11
A. barreirensis - B6
A. barreirensis - B8
A. barreirensis - B5
A. barreirensis - B4
A. barreirensis - B4
A. barreirensis - B7
A. barreirensis - B1
A. barreirensis - B1
A. barreirensis - UB3686

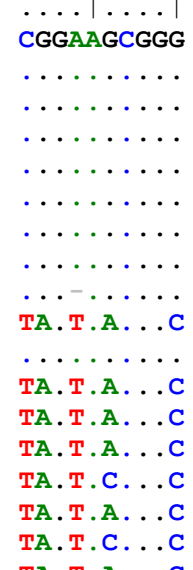
Cocos nucifera - H0265515.1 A....... 
A. barreirensis - B16

A. eichleri - E18

A. eichleri - E17

A. funifera - 7

A. funifera -15

A. funifera -15

A. speciosa - S4

A. speciosa - S5

A. speciosa - S17
A. phalerata - P12

A. phalerata - P36

$A$. vitrivir - 2BM

A. vitrivir - 1BM

A. vitrivir - 2M1

A. vitrivir - 1M1

A. eichleri - UB1091

A. vitrivir - CEN1075
A. phalerata - UB238

A. speciosa - UB10110

A. barreirensis - UB36868

A. teixeirana - híb -

A. eichleri - BA4

A. teixeirana - híb - СТ01

A. teixeirana - híb - CT01
A. teixeirana - híb - CT37

A. teixeirana - hib

A. teixeirana - híb - FZ12

A. teixeirana - híb - Ст02

A. eichleri - СТ07

A. teixeirana - híb - Ст20

Cocos nucifera - GQ435464.1

10 20 30

40

50

60

70

80

90

100

110

СтTTTGTCTTAGTGTATATGAATCGTTGAAGGATGGAGCAATACCCAA- тATCTTGTTTTAGTTGGTATTGCTCCATTGTTTGATTCAATAGTGTTTTGCACACAACA

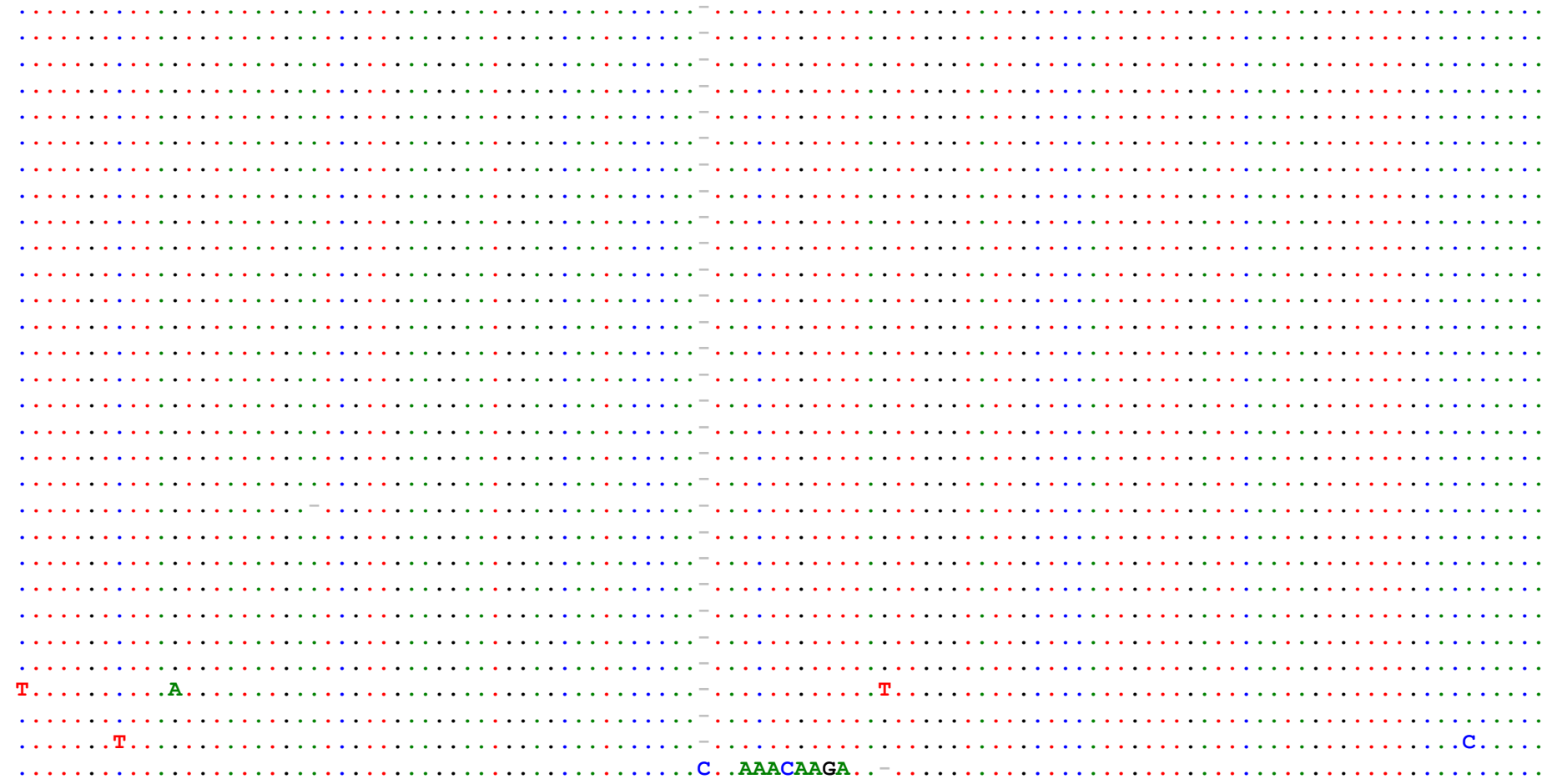




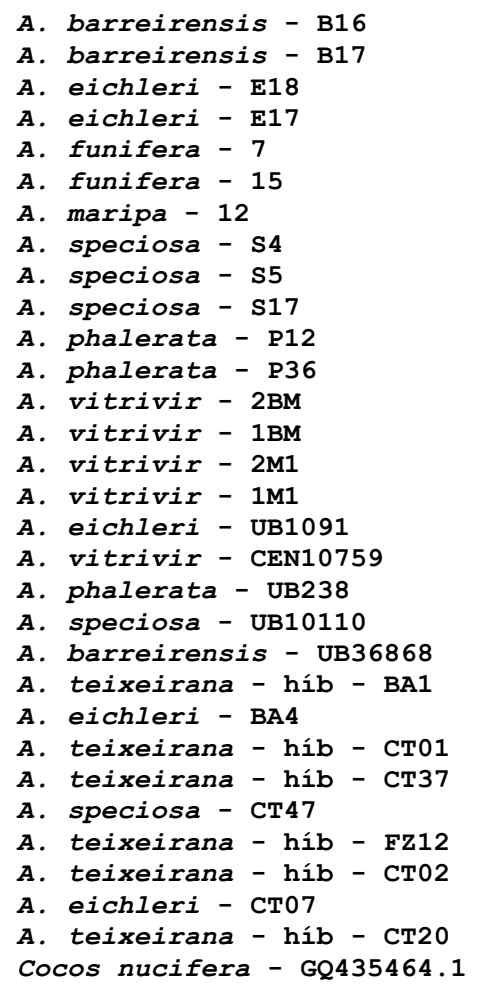

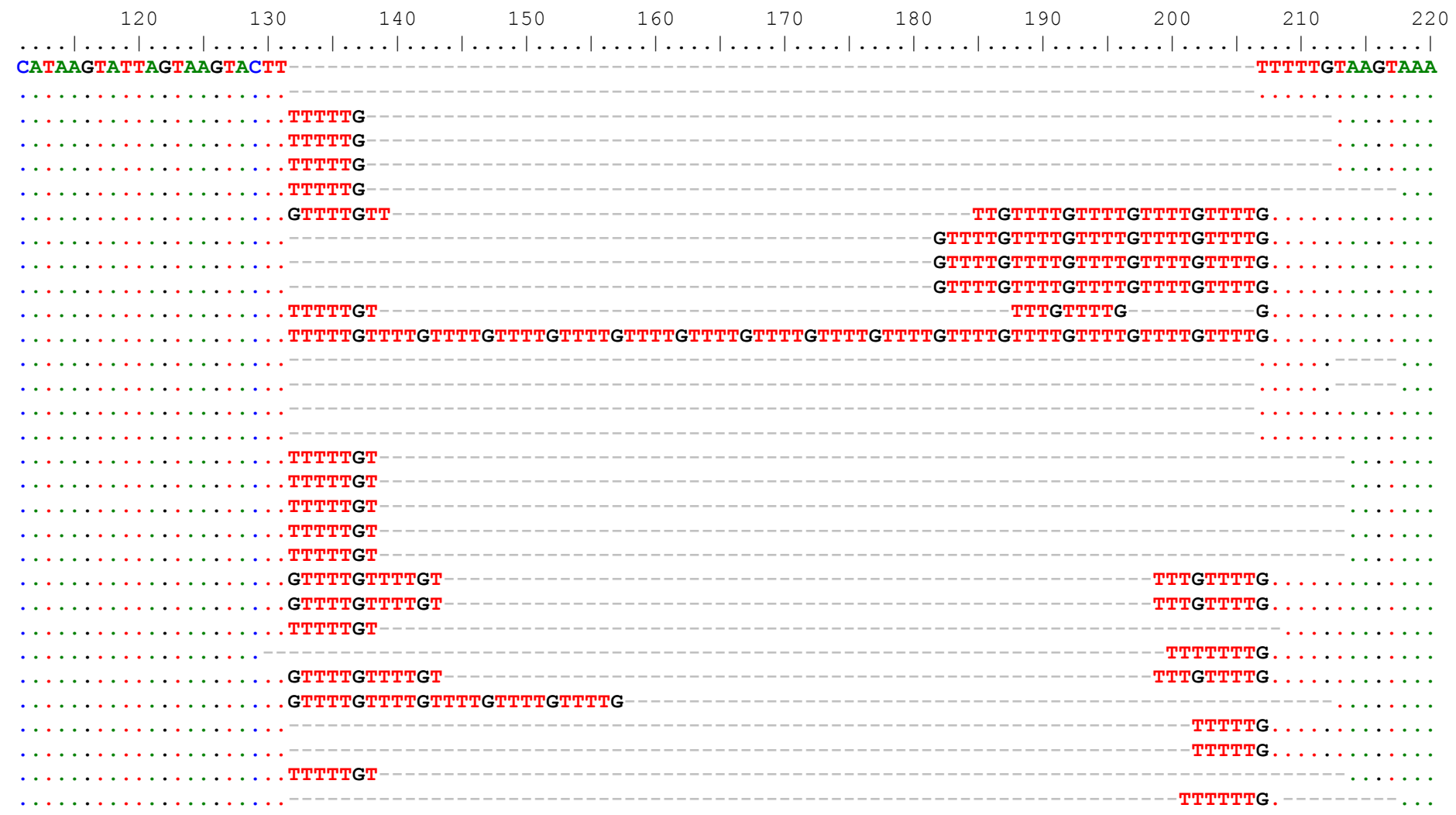


Continuação das sequências de $p s b A$-trn $H$

A. barreirensis - B16
A. barreirensis - B17
A. eichleri - E18
A. eichleri - E17
A. funifera - 7
A. funifera - 15
A. maripa - 12
A. speciosa - S4
A. speciosa - S5
A. speciosa - S17
A. phalerata - P12
A. phalerata - P36
A. vitrivir - 2BM
A. vitrivir - 1BM
A. vitrivir - 2M1
A. vitrivir - 1M1
A. eichleri - UB1091
A. vitrivir - CEN10759
A. phalerata - UB238
A. speciosa - UB10110
A. barreirensis - UB36868
A. teixeirana - híb - BA1
A. eichleri - BA4
A. teixeirana - híb - CT01
A. teixeirana - híb - CT37
A. speciosa - CT47
A. teixeirana - híb - FZ12
A. teixeirana - híb - CT02
A. eichleri - CT07
A. teixeirana - híb - CT20
Cocos nucifera - GQ435464.1

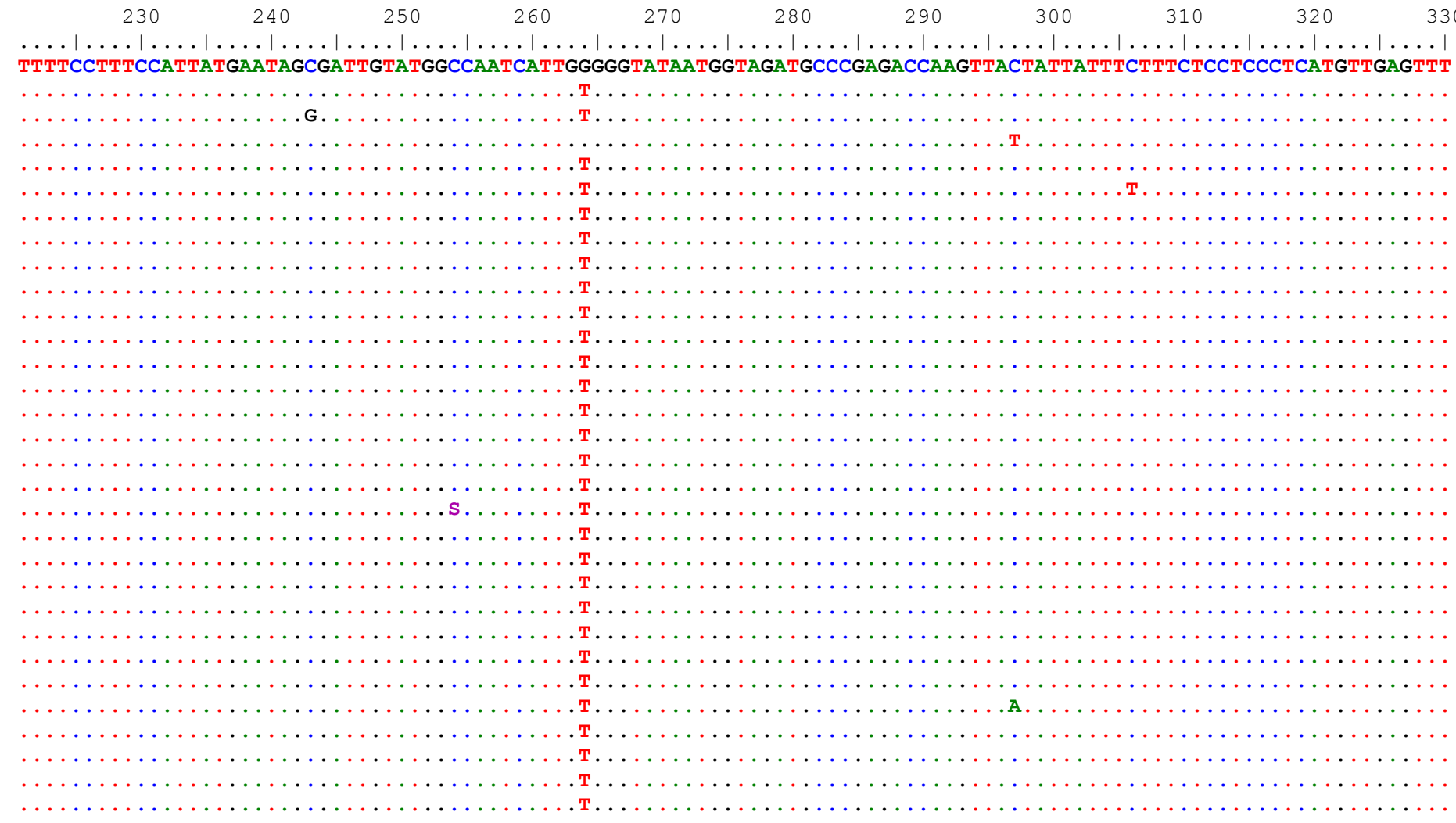


Continuação das sequências de $p s b A$-trnH

A. barreirensis - B16

A. barreirensis - B17

A. eichleri - E18

A. eichleri - E17

A. funifera - 7

A. funifera -15

A. maripa - 12

A. speciosa - S4

A. speciosa - S5

A. Speciosa - $\mathrm{S} 17$

A. phalerata - P12

A. phalerata - P36

A. vitrivir - 2BM

A. vitrivir - $1 \mathrm{BM}$

A. vitrivir - 2M1

A. vitrivir - 1M1

A. eichleri - UB1091
A. vitrivir - CEN10759

A. vitrivir - CEN10759
A. phalerata - UB238

A. phalerata - UB238
A. speciosa - UB10110

A. barreirensis - UB36868

A. teixeirana - híb - BAI

A. eichleri - BA4

A. teixeirana - híb - Ст01

A. teixeirana - híb - СТ37

A. speciosa - СT47

A. teixeirana - híb - FZ12

A. teixeirana - híb - CT02

A. teixeirana - híb

A. eichleri - СT07

A. teixeirana - híb - CT20
Cocos nucifera - G0435464.1 $\begin{array}{llllllllll}340 & 350 & 360 & 370 & 380 & 390 & 400 & 410 & 420 & 430\end{array} 440$ TTCCATTTTCCCGATAAATGATTAGCTACAAAAGGATTTTTTTTAGTGA.

A

$\cdots$

A. A.

. A

$\ldots$
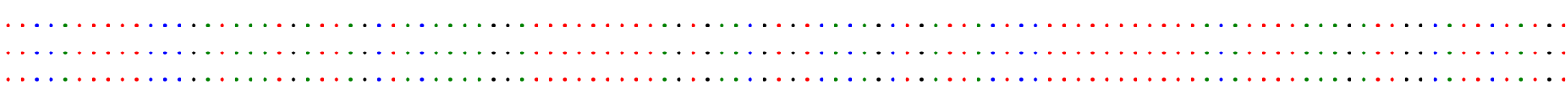

A 
Continuação das sequências de $p s b A$-trn $H$
A. barreirensis - B16
A. barreirensis - B17
A. eichleri - E18
A. eichleri - E17
A. funifera - 7
A. funifera - 15
A. speciosa - S4
A. speciosa - S5
A. speciosa - S17
A. phalerata - P12
A. phalerata - P36
A. vitrivir - 2BM
A. vitrivir - 1BM
A. vitrivir - 2M1
A. vitrivir - $1 \mathrm{M} 1$
A. eichleri - UB1091
A. vitrivir - CEN10759
A. phalerata - UB238
A. speciosa - UB10110
A. barreirensis - UB36868
A. teixeirana - híb - BA1
A. eichleri - BA4
A. teixeirana - híb - Ст01
A. teixeirana - híb - СT37
A. speciosa - CT47
A. teixeirana - híb - FZ12
A. teixeirana - híb - СТ02
A. eichleri - СТ07
A. teixeirana - híb -
A. teixeirana - hib - CT20

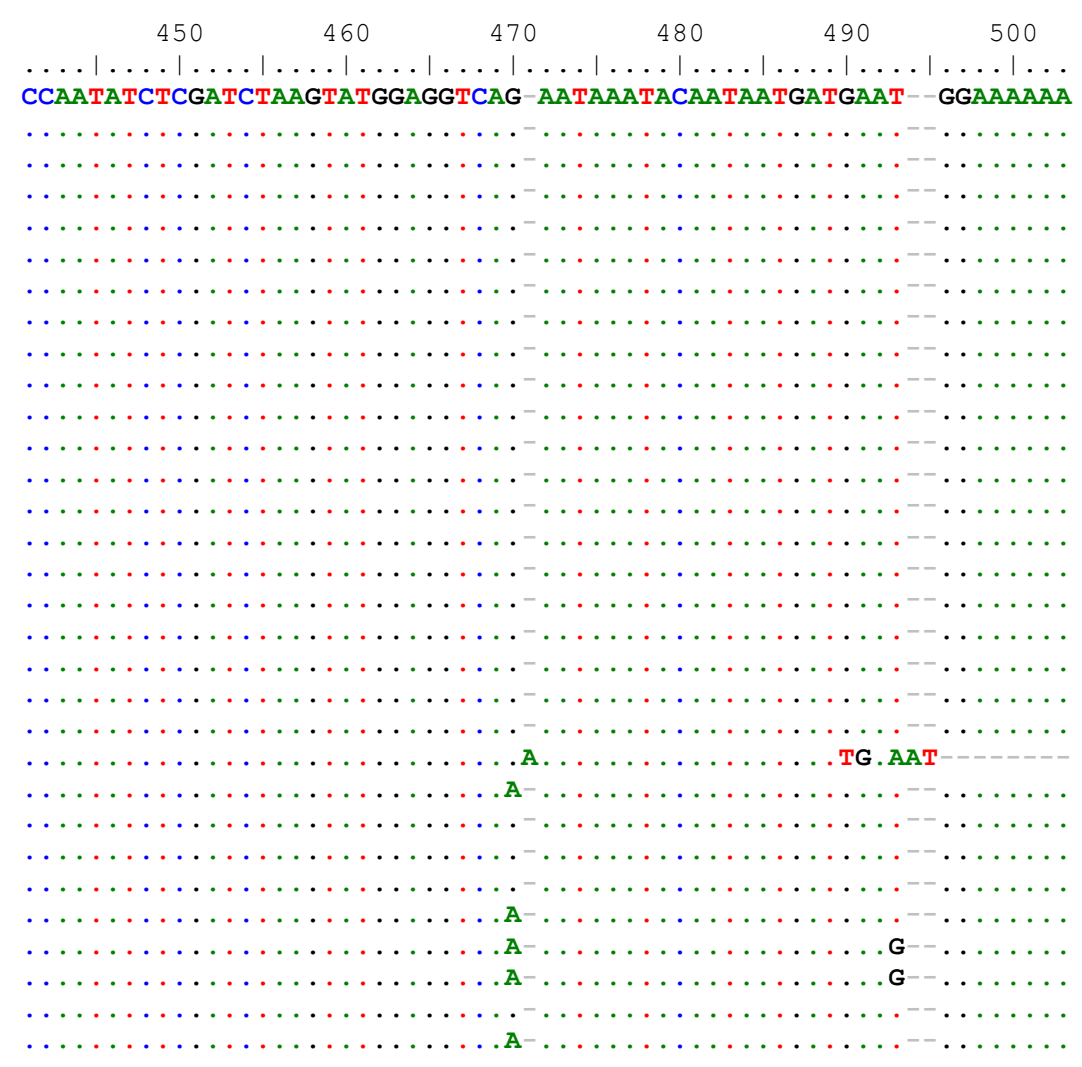


Sequências de PRK

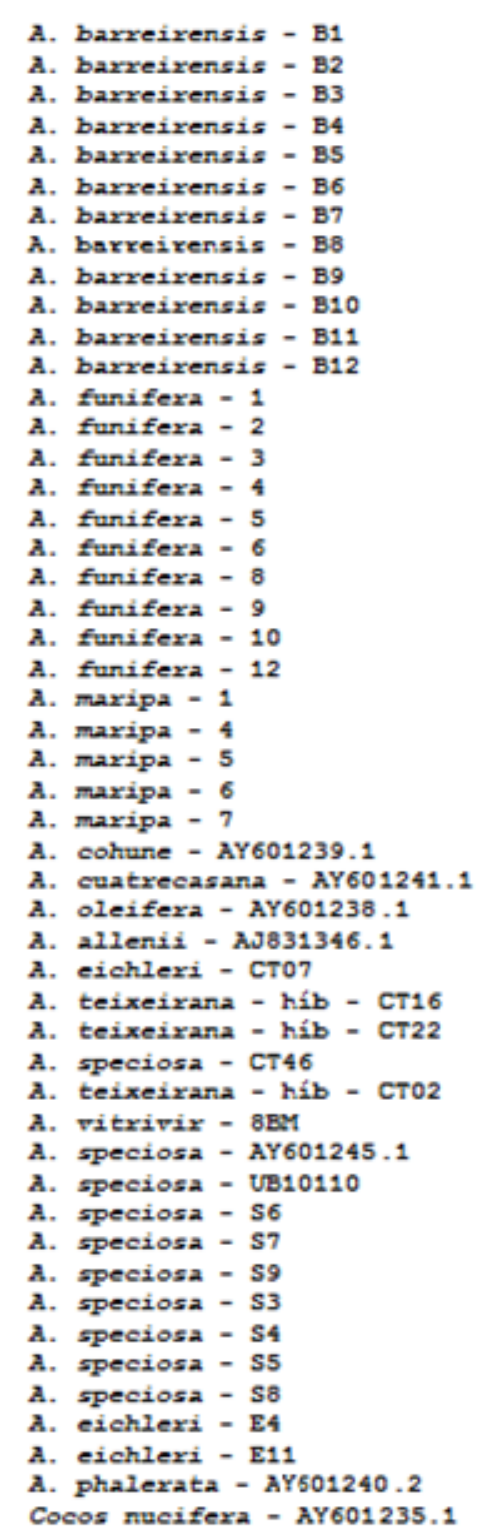

Gс..1...

20

30

40

50

60

70

80

90

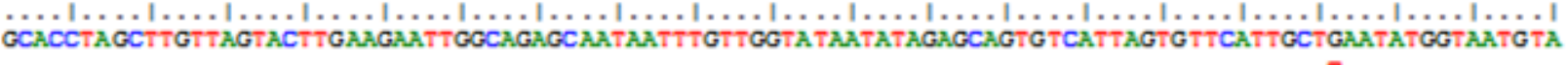

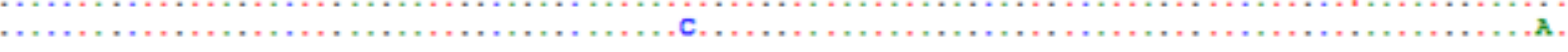

$$
\begin{aligned}
& \text { c. } \\
& \text { c. } \\
& \text { c. }
\end{aligned}
$$

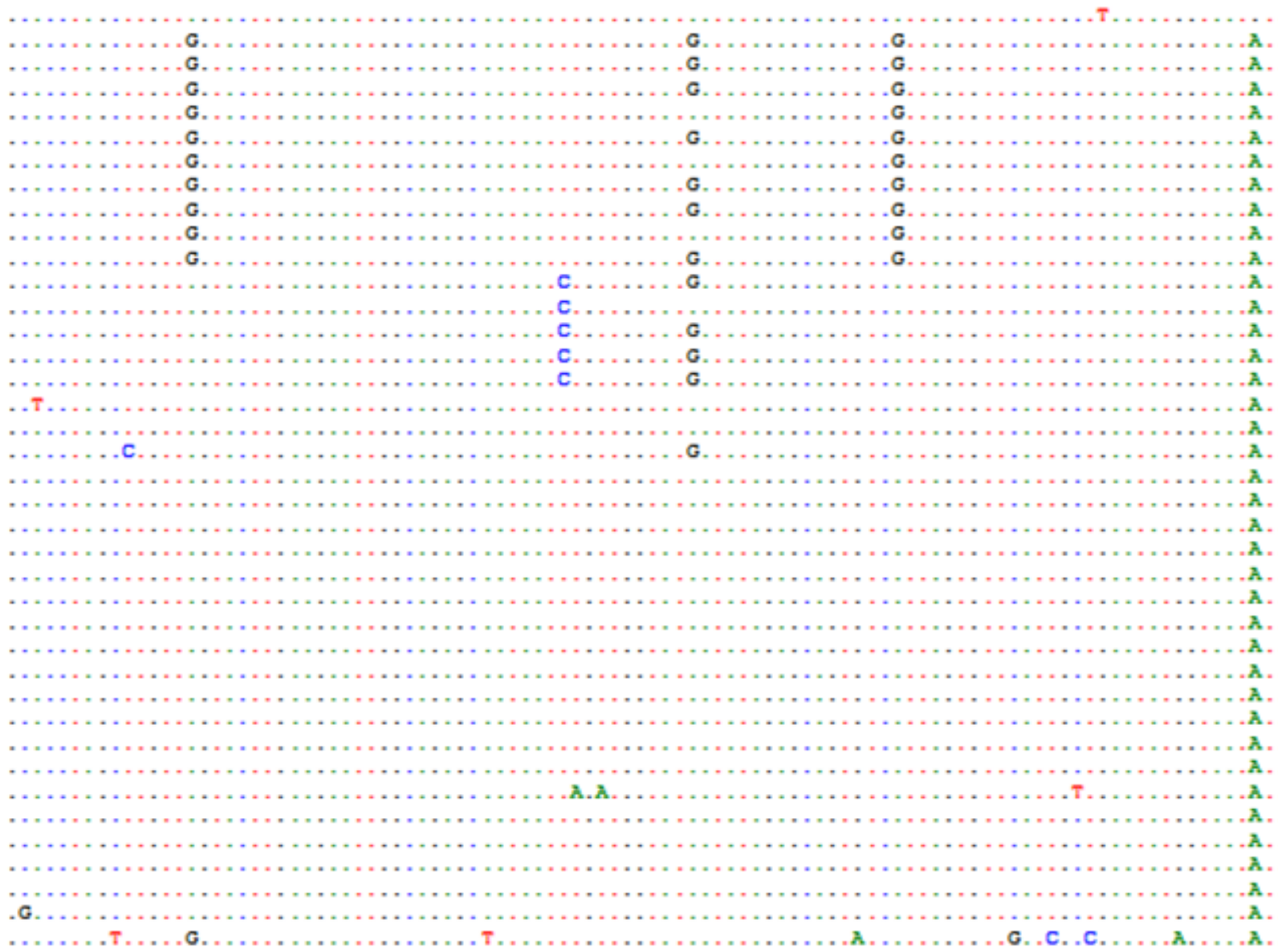


Continuação das sequências de PRK

$\begin{array}{llllllllll}110 & 120 & 130 & 140 & 150 & 160 & 170 & 180 & 190 & 200\end{array}$

A. barreirensis - B1

A. barreirensis - B2

A. barreirensis - B4

A. barreirensis - B5

A. barreirensis - B6

A. barreirensis - B7

A. barreirensis - B9

A. barreirensis - B10

A. barreirensis - B11

A. funifera -1

A. funifera - 2

A. funifera - 3

A. funifera -4

A. funifera -5
A. funifera -6

A. funifera - 8

A. funifera - 9

A. funifera - 10

A. funifera -

A. Maxipa -1

A. maxipa $=4$

A. maxipa -5

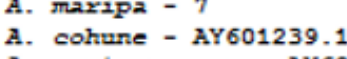

A. cuatrecasana - AY601241.1

A. oleifera - AY601238.1

A. oleifera - AY601238.1
A. 2llenii - AJ831346.1
A. eichleri - CT07

A. teixeirana - híb - CT16

A. teixeirana - híb - CT16
A. teixeirana - híb - CT22

A. Tpeciosa - CT46

A. teixeirana $-\mathrm{h}$

A. vitrivix - 8BM
A. speciosa - AY601245.1

A. speciosa - UB10110

A. Speciosa - UB10
A. Speciosa - S6

A. speciosa - S7

A. speciosa - 59

A. speciosa - $\$ 3$

A. Speciosa - 54

A. speciosa - S5

A. Speciosa - S

A. elchlexi - E4

A. eichleri - E11

A. phalerata - AY601240.2

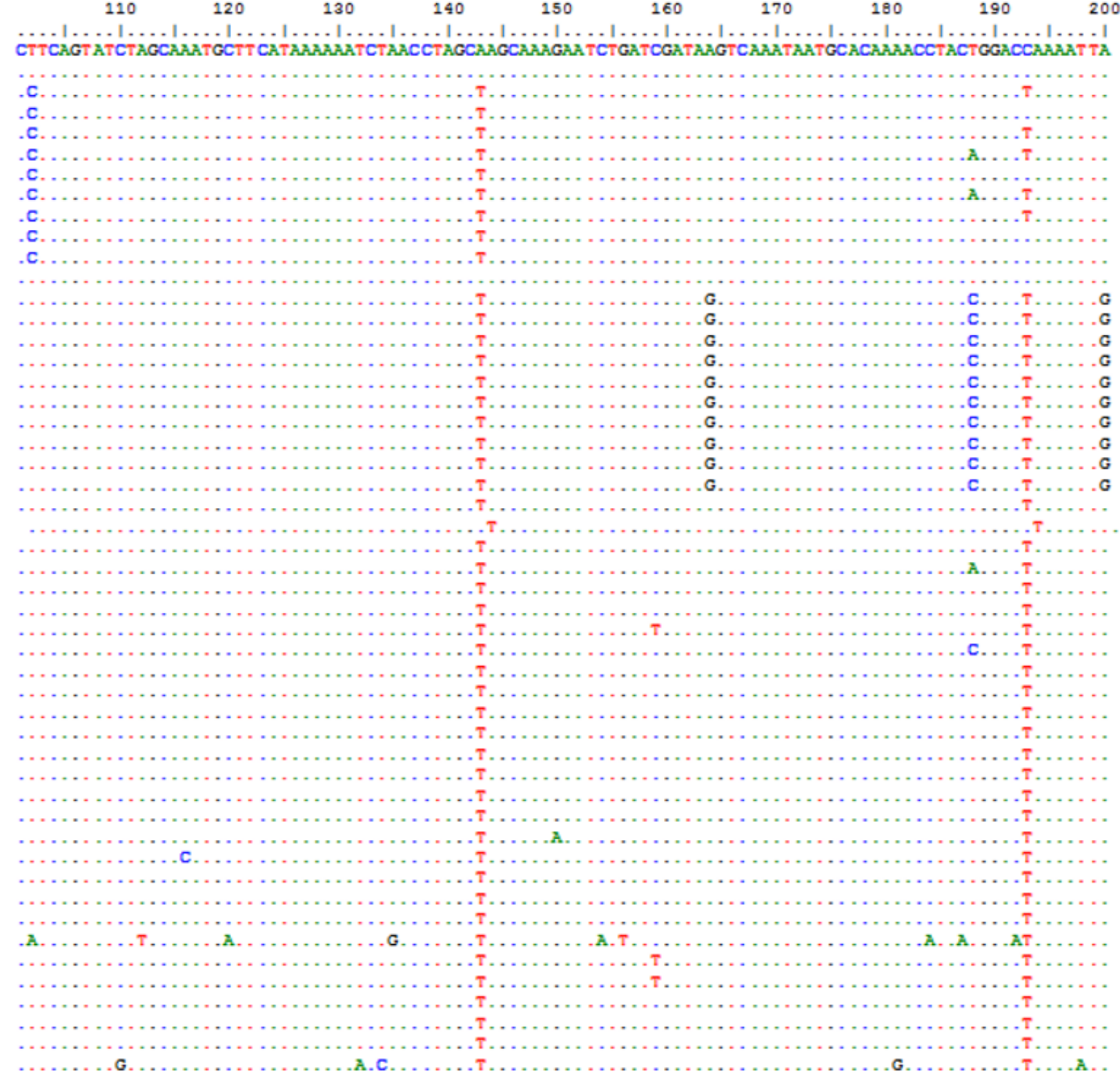


Continuação das sequências de PRK

A. barreirensis - B1
A. barreirensis - B2
A. barreirensis - B3
A. barreirensis - B4
A. barreriensis - B5
A. barreirensis - B6
A. barreirensis - B7
A. barreirensis - B8
A. barreirensis - B9
A. barreirensis - B10
A. barreirensis - B11
A. barreirensis - B12
A. funifera - 1
A. funifera - 2
A. funifera - 3
A. funifera - 4
A. funifera - 5
A. funifera - 6
A. funifera - 8
A. funifera - 9
A. funifera - 10
A. funifera - 12
A. maripa - 1
A. maripa - 4
A. maripa - 5
A. maripa - 6
A. maripa - 7
A. cohune - AY601239.1
A. cuatrecasana - AY601241.1
A. oleifera - AY601238.1
A. allenii - AJ831346.1
A. eichleri - CT07
A. teixeirana - híb - CT16
A. teixeirana - híb - CT22
A. speciosa - CT46
A. teixeirana - híb - CT02
A. vitrivir - 8BM
A. speciosa - AY601245.1
A. speciosa - UB10110
A. speciosa - S6
A. speciosa - S7
A. speciosa - S9
A. speciosa - S3
A. speciosa - S4
A. speciosa - S5
A. speciosa - S8
A. eichleri - E4
A. eichleri - E11
A. phalerata - AY601240.2
Cocos nucifera - AY601235.1

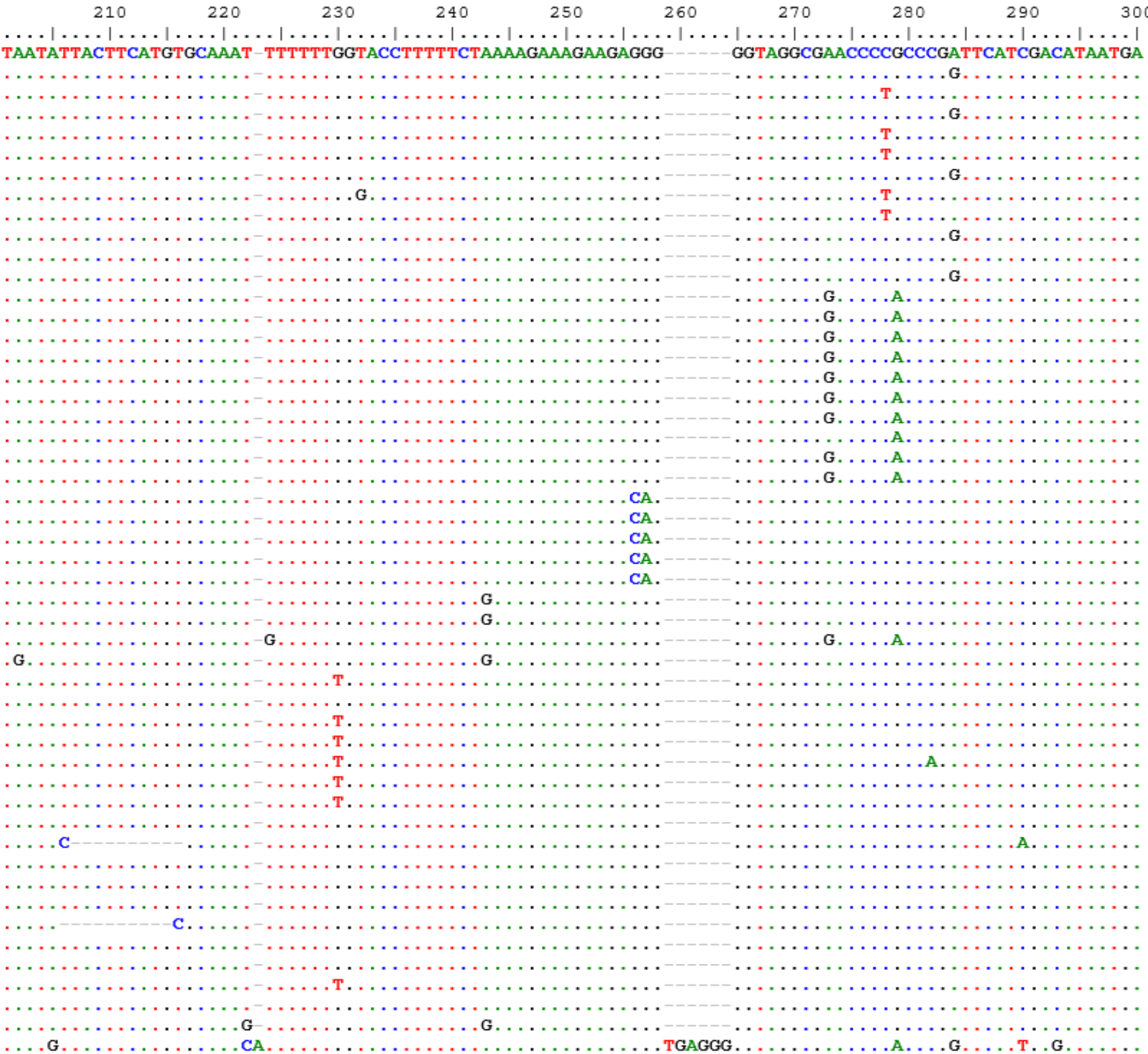


Continuação das sequências de PRK

A. barreirensis - B1

A. barreirensis - B2

A. barreirensis - B3

A. barreirensis - B4

A. barreriensis - B5

A. barreirensis - B6

A. barreirensis - B7

A. barreirensis - B8

A. barreirensis - B9

A. barreirensis - B10

A. barreirensis - B11

A. barreirensis - B12

A. funifera - 1

A. funifera - 3

A. funifera - 4

A. funifera - 5

A. funifera - 6

A. funifera - 8

A. funifera - 10

A. funifera - 12

A. maripa - 1

A. maripa

A. maripa - 5

A. maripa - 6

A. maripa - 7
A. Cohune - AY601239.1

A. cuatrecasana - AY601241.1

A. oleifera - AY601238.1

A. allenii - AJ831346.1

A. eichleri - CT07

A. teixeirana - híb - CT16
A. teixeirana - híb - СT22

A. speciosa - CT46

A. teixeirana - híb - СТ02

A. vitrivir - 8BM

A. speciosa - AY601245.1

A. speciosa - UB10110

A. speciosa - S6

A. speciosa - S9

A. speciosa - S3

A. speciosa - S4

A. speciosa - S5

A. speciosa - S8

A. eichleri - E4

A. eichleri - E11

A. phalerata - AY601240.2

Cocos nucifera - AY601235.

320

330

340

350

360

370

380

390

GACAATTAGAT-TGCTGAGTCTTATGTTCTCAGATATCAGAATATCCATTCTTTCTTTAGCAC-GTTTGGATTATTGACGGCTATAGATTGCTACCCT

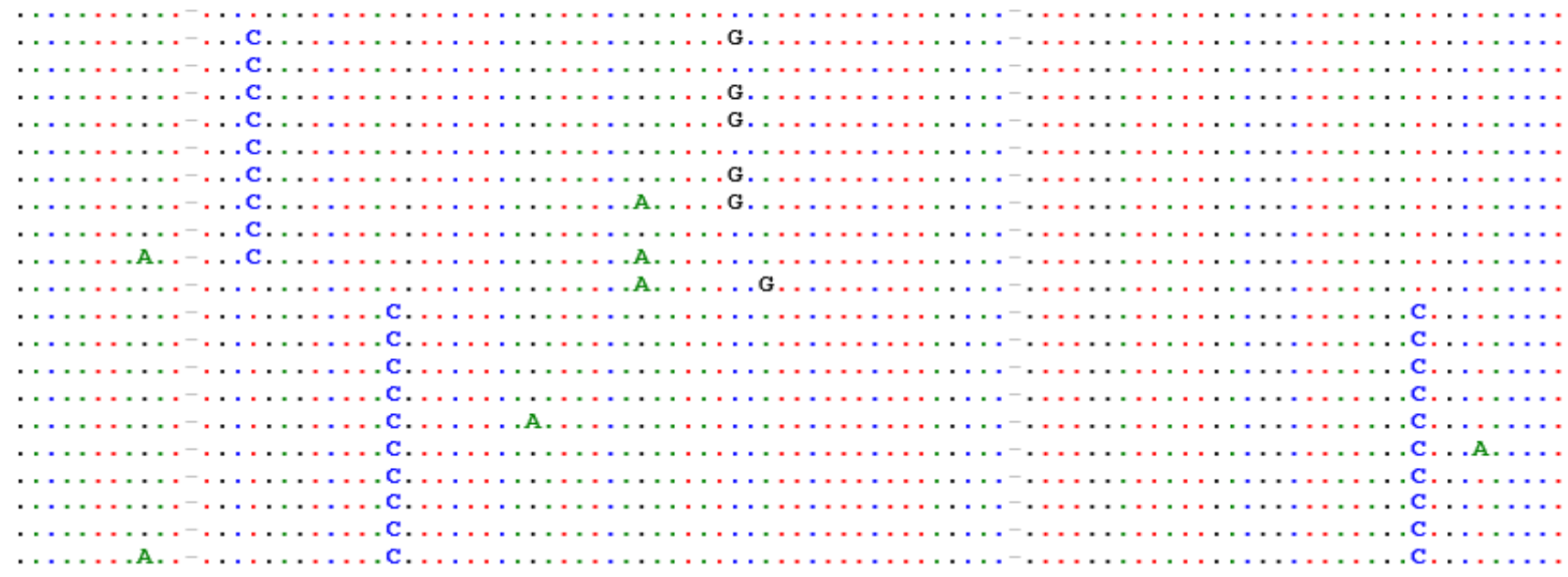

.........

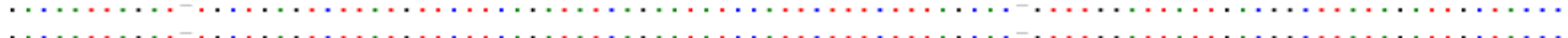

(1...

.

…

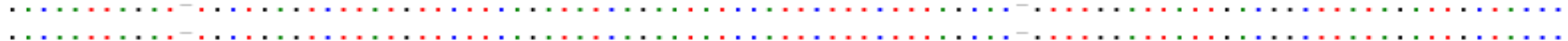



.

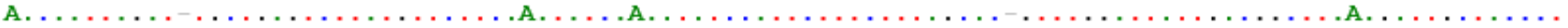



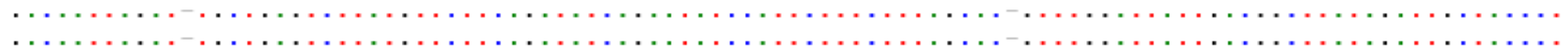

…



… 
Continuação das sequências de PRK

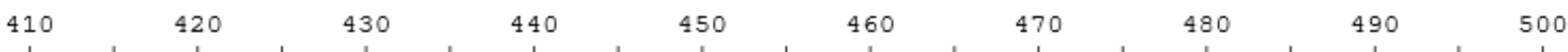

A. barreirensis - B1

A. barreirensis - B2

A. barreirensis - B3

A. barreirensis - B3

A. barreriensis - B5

A. barreirensis - B6

A. barreirensis - B7

A. barreirensis - B8

A. barreirensis - B9

A. barreirensis - B10

A. barreirensis - B12

A. funifera - 1

A. funifera - 2

A. funifera - 3

A. funifera - 5

A. funifera - 6

A. funifera - 8

A. funifera - 10

A. funifera - 10

A. funifera -

A. maripa - 1

A. maripa - 5

A. maripa - 6

A. maripa - 7
A. cohune - AY601239.1

A. cuatrecasana - AY601241.1

A. oleifera - AY601238.1

A. allenii - AJ831346.
A. eichleri - CT07

A. teixeirana - híb - CT16

A. teixeirana - híb - CT16
A. teixeirana - híb - CT22

A. teixeirana - híb - CT22

A. teixeirana - híb - СТ02

A. teixeirana - hib
A. vitrivir - 8BM
A. speciosa - AY601245.1

A. speciosa - AY601245

A. speciosa - S6

. speciosa - S7

. speciosa - S9

. speciosa - S3

A. speciosa - 54

. speciosa - S5

Apeciosa - $\mathbf{5 8}$

A. eichleri - E4

A. eichleri - E11

A. phalerata - AY601240.2
Cocos nucifera - AY601235.1

GGCAGACCCACAGAAGCAATATGCTGATGTCGTAATTGAGTTTTACCGACACAATTAATTCCTGATGACAATGAAAGGAAGGTGCTGAGAGTTCGATTC

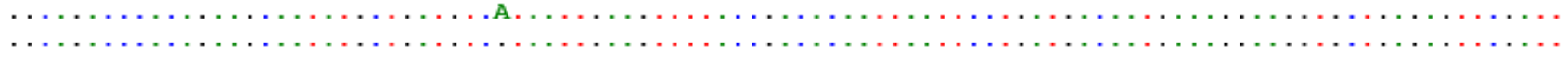

.G.

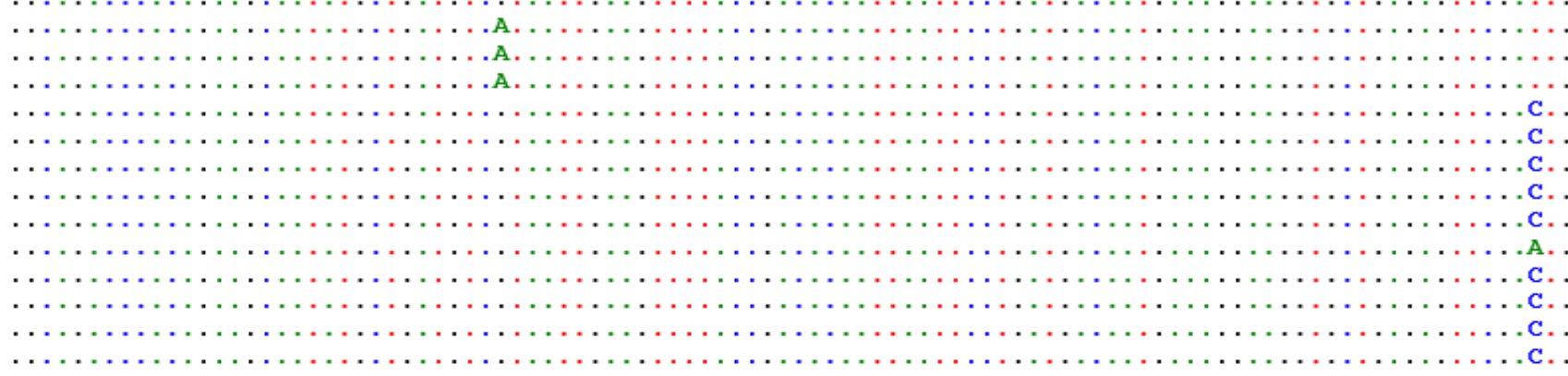

. . . . . . . .

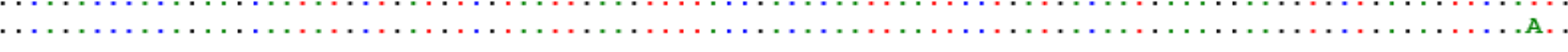

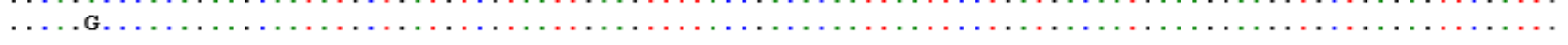



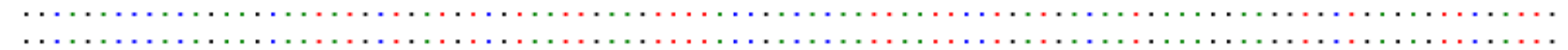


A. barreirensis - B1

A. barreirensis - B2

A. barreirensis - B3

A. barreirensis - B4

A. barreriensis - B5

A. barreirensis - B6

A. barreirensis - B7

A. barreirensis - B8

A. barreirensis - B9

A. barreirensis - B10

A. barreirensis - B12

A. funifera - 1

A. funifera - 2

A. funifera - 3
A. funifera - 4

A. funifera - 5

A. funifera - 6

A. funifera - 9

A. funifera - 10
A. funifera -12

A. funifera -

A. maripa - 4

A. maripa - 5

A. maripa - 6

A. maripa - 7
A. cohune - AY601239.

A. Cohune - AY601239.1
A. cuatrecasana - AY601241.

A. oleifera - AY601238.1

A. allenii - AJ831346.1

A. eichleri - СT07

A. teixeirana - híb - CT16

A. teixeirana - híb - CT22

A. speciosa - CT46

A. teixeirana - híb - СТ02

A. vitrivir - 8BM

A. speciosa - AY601245.1

A. speciosa - UB10110

A. speciosa - $\mathrm{S} 6$

A. speciosa - S7

A. speciosa - S9

A. speciosa - S3

A. speciosa - S4

A. speciosa - S5

A. speciosa - $\mathbf{5 8}$

A. eichleri - E4
A. eichleri - E11

A. phalerata - AY601240.2

Cocos nucifera - AY601235.1
$510 \quad 520 \quad 530$

$\ldots|\ldots| \ldots|\ldots| \ldots|\ldots| \ldots|\ldots|$
GTGATGAAAGAGGGGTAATACTTCGATC

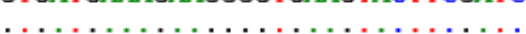

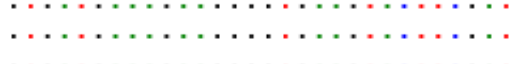

…

…

…

…

.

…

…

…

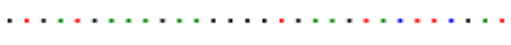

…

…

n.w. $\ldots \ldots \ldots \ldots \ldots \ldots$

n.m.

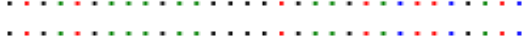

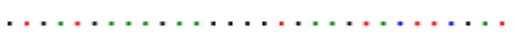

n.m.

...........................

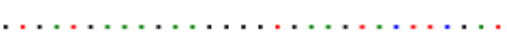

-

n.w. $\ldots \ldots \ldots \ldots \ldots \ldots \ldots$

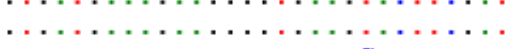

…

…

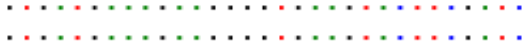

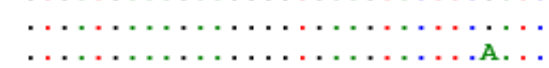

